

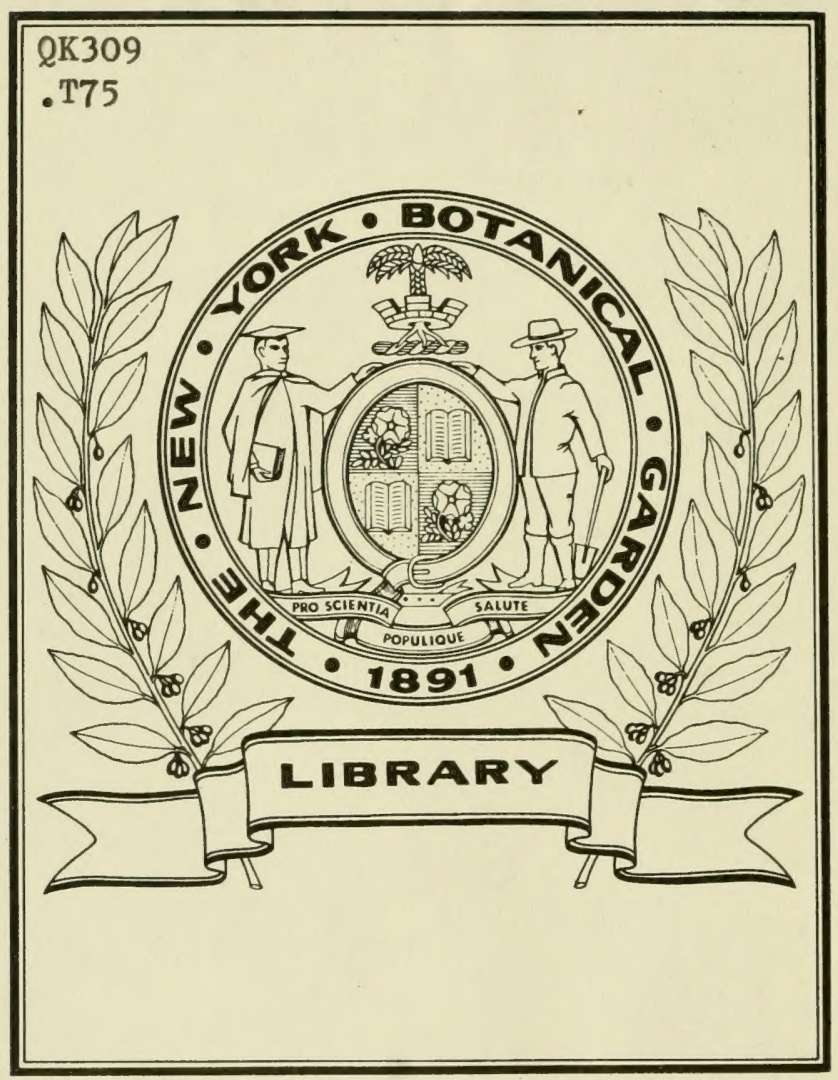


\&vpe.

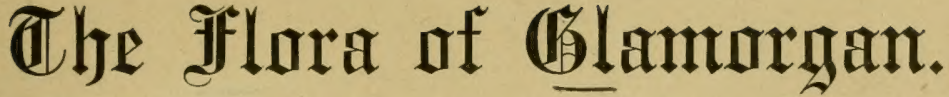

INCLUDING THE

Spermaphytes \& Vascular Cryptogams, with Index.

Prepared under the direction of a Committee of the Cardiff Naturalists' Society.

EDITED BY

PROFESSOR A. H. TROW, D.Sc., F.L.S.

\section{VOL. I.}

Printed for the Society by William Lewis, Duke Street, Cardiff.

IgII.

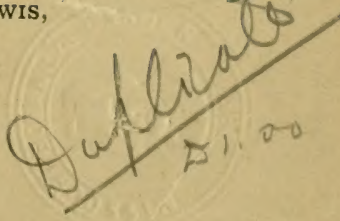


Copyright.-Entered at Stationers' Hall by the Cardiff Naturalists' Society. 
Originally published in five Sections as Supplements to the Transactions of the Cardiff Naturalists' Society, viz.:-

Section I.

Thalamifloræ, Vol. XXXIX., Trans. C.N.S., Igo6.

Section 2.

Calycifloræ, Vol. XL., Trans. C.N.S., I907.

SEction 3.

Corollifloræ, Vol. XLI., Trans. C.N.S., Igo8.

Section 4 .

Incompletæ, Vol. XLII., Trans. C.N.S., I9o9.

\section{Section 5 .}

Monocotylodons and Vascular Cryptogams, Vol. XLIII., Trans. C.N.S., IgIo. 



\title{
THE FLORA OF GLAMORGAN.
}

\author{
Edited by A. H. TROW, D.Sc., F.L.S.
}

\section{PREFACE.}

The flora of the County of Glamorgan, notwithstanding the exertions of local and other botanists, is still very imperfectly understood. The Cardiff Naturalists' Society, in I886, published the first material contribution to its elucidation under the somewhat misleading title of the "Flora of Cardiff." This work was perhaps the most important of the many scientific enterprises of the late Mr. John Storrie, and is certainly the one by which he is most widely known. As indicated in the full title, and exactly delimited in the Preface, the area covered in that work comprised the eastern half of Glamorgan. Glamorgan has not been well supplied with indigenous botanists, and the eastern half of the County had, in particular, been much neglected before Mr. Storrie commenced his somewhat solitary labour. Associated with this gentleman, however, were a few botanists, who furnished him with considerable stores of material in the form of local records. The names of Messrs. R. Drane, T. H. Thomas, Chapman, Bell, Mrs. Traherne, Miss Ollivant, and Dr. C. T. Vachell may be mentioned as chief among those who furnished active help.

Mr. Storrie was by no means satisfied with his work in the form in which it ultimately appeared. He recognised that many of the "critical " forms had received too little attention; he was quite aware that there were many sins of omission as well as some of commission; and he consequently made preparations, not very energetic ones, it is true, for his health was fast failing 
him, for issuing a second edition at the first convenient opportunity. Some time after his death, in Igor, the Cardiff Naturalists' Society acquired his manuscript copy of the additions and corrections he proposed to make to his work. Most of his botanical work will thus be preserved, and serve as the basis for the first County "Flora of Glamorgan."

Before this date, however, Dr. C. T. Vachell had, on several occasions, urged the Society to take up the work of producing a more comprehensive and satisfactory local Flora. Two years after Mr. Storrie's death, the Committee accepted his proposals, and it was arranged that the Society should make itself responsible for a "Flora of Glamorgan," the old district of the Society being enlarged so as to embrace the whole of the County, and thus coincide with division 4I of Watson's "Topographical Botany."

To organise and supervise this work a special Committee was appointed in November, I903, consisting of the following members :-

Chairman-A. H. Trow, D.Sc., University College, Cardiff.

R. Drane, F.L.S., Queen Street.

J. J. Neale, Penarth.

T. W. Proger, Richmond Road.

Thomas Henry Thomas, 45, The Walk. (T.H.T.)

W. Gilbert Scott, Richmond Road.

W. W. Pettigrew, Roath Park. (P.)

Hon. Secs.-Dr. C. T. and Miss Vachell, II, Park Place.

The Committee at once authorised the issue of circulars to local botanists inviting them to become corresponding members and furnish lists of the wild plants occurring in their respective neighbourhoods. In the following list are included the names and addresses of all those who responded to the invitation, those who forwarded lists of plants to the Secretaries in 1905 being distinguished by the abbreviations in brackets.

List of Active Corresponding Members for I905.

I. A. Bennett, 5, Edridge Road, Croydon. (A.B.) 
2. Mrs. Bennett, 5, Edridge Road, Croydon.

3. W. W. Boucher, Wycomb, Porthkerry Road, Barry.

4. Miss H. O. Booker, Slon, Southerndown, Glam. (Miss B.)

5. T. Chapman, I04, Queen Street, Cardiff.

6. E. Louden Downing, St. David's, Barry. (D.)

7. Miss Maud David, The Hendre, Llandaff. (M.A.D.)

8. Rev. W. F. Evans, The School, Cowbridge.

9. John Evans, F.L.S., H.M.I.S., Spring Hill Villa, Merthyr Tydfil. (E.)

Io. Harold Evans, The Hardy Plant Nursery, Llanishen. (H.E.)

II. Illtyd Buller Pole-Evans, B.Sc., Llanmaes, Llantwit Major.

I2. G. Fleming, M.A., 9, Fair View Terrace, Merthyr Tydfil. (F.)

I3. Rev. John Griffith, Nantymoel, Glam.

I4. James I. Graham, Sully Grange, Sully, near Cardiff.

I5. H. Harries, Church Villa, Ystrad, Rhondda.

I6. Miss Insole, Fairwater House, Llandaff.

I7. J. E. Morgan, Higher Grade School, Aberdare.

I8. C. S. Nicholson, F.L.S., 22, Crouch Hall Road, Crouch End, E.C. (N.)

I9. W. Parfitt, 35, Bailey Street, Ton Pentre.

20. Captain George Traherne, Coedriglan Park. (G.T.)

2I. B. A. Williams, The County Schools, Penderyn, Breconshire. (W.)

To save space, these names will be referred to hereafter by the abbreviations placed after them in brackets.

The Flora will be divided into five parts, dealing respectively with the groups-now admittedly artificial-familiar to British students under the names of :-

I. Thalamifloræ.

2. Calycifloræ.

3. Corollifloræ.

4. Incompletæ.

5. Monocotyledons and Vascular Cryptogams.

One of these parts will be published each year in the Transactions of the Society in such a form that when completed the 
whole may be bound together to form a single volume. The order will be that of the numbers given above-No. I will appear in I907, and No. 5 in I9II.

In order to secure uniformity of treatment and the necessary brevity, the records for the separate species will follow definite lines. Following the excellent example set by Watson in his standard works on distribution, each record will, so far as possible, be condensed into a formula. As a rule, three paragraphs, the first two of a line each, will be devoted to each plantthe first for the names, the second for the general distribution, and the last for the detailed distribution and citation of particular habitats.

The nomenclature presents special difficulties. It is impossible to adhere absolutely to any one system. The Editor is primarily responsible for the names used. In all cases the authority for the name will be cited. The names of the $9^{\text {th }}$ edition of the London Catalogue will be adhered to, with certain exceptions rendered necessary by the recent development of our knowledge of the so-called "critical" species. The numbering of the Catalogue will be quoted throughout, so that a ready means will be furnished for noting the absence of plants from Glamorgan, and of making comparisons with other local Floras.

The first line therefore devoted to each plant will be occupied by (I) its number in the London Catalogue; (2) its technical name; (3) its commonest English name or names; and (4) its Welsh name or names. Mr. T. H. Thomas has undertaken to supervise the Welsh nomenclature and to furnish, whenever possible, the Glamorgan names. When a special note on names is necessary, it will be added below in smaller print. Mr. Thomas makes the following explanatory note :-

"The Welsh names appended were taken by Mr. John Storrie, F.L.S., from Richards' “Dictionary," I75I; Davies' "Welsh Botanology," I8I3; "Physygwriaeth yr Hwsmon a'r Tylodion," I 839; and "Y Llysieu-Lyfr Teuleuaidd," I 858. 
In addition, the Herbals in Williams' "Faunula Grustensis," I830 ; "Geirlyfr Caerfallwch," I850 ; and "Gaelic Names of Plants," by Cameron, I883, have been collated.

The number of ancient Cymric names of plants is small; as in all other languages they are confined to those economically useful or medicinal. During the Norman period some were added. Following upon the Renaissance many names were imported from English, and perhaps Dutch, sources. In recent Welsh Herbals, very many names are simply translated from English works; a large proportion of these are not here inserted. A few local names are added.

During the period covered by the works above-named, changes have taken place in Welsh orthography. Names are given as they occur in the lists quoted from."

The second line is intended to express the general distribution and type of habitat by the use of as few words as possible. In general, four words must suffice. The first of these, chosen from the following three-common, local, rare-is used to indicate the frequency of habitats, or places where the species may be found. The second, chosen from the following three-abundant, frequent, scarce - is used to indicate the frequency of the occurrence of individuals in the habitats. The third, chosen from Watson's well-known terms-native, denizen, colonist, alien-shows what claim the species has to inclusion in the Flora, and gives its status. The fourth, adopted from Watson's Cybele Britannica, Vol. I., pp. 65, 66, - septal, sylvestral, \&c. - sufficiently describes the kind of habitat in which the species normally occurs.

Many objections can be urger against this abbreviated method of record, and especially against the terms actually selected. The new œcological nomenclature is scarcely an improvement on that of Watson. A more elaborate system would perhaps have served better, however, had the County been more systematically worked.

The third paragraph is reserved for the detailed distribution or local records, and for special notes on points of interest. 
When a species is common and abundant, this paragraph will be omitted as superfluous. Rare and critical species will receive special attention-the localities in which they occur will be fully quoted, together with the authorities for the records. The Secretaries are mainly responsible for this citation. Upon them has devolved the work of collating the reports of the corresponding members. The sign of certainty (!) indicates that a specimen has been seen by the Editor, and when the sign is affixed to a locality, in that locality.

The double sign (!!) indicates that the record has been confirmed by Mr. A. Bennett, F.L.S., of Croydon. Nuch of the value attached to the records of the more critical forms is due to the untiring and constant help afforded to the Editor and Secretaries by this most distinguished and expert student of the British Flora. It is noteworthy that the specimens of the Cardiff Museum Herbarium have all been submitted to him for revision of the nomenclature, and that collection has now therefore a very special value for local botanists. The sign (?) implies suspicion or doubt of the accuracy of the record.

The Editor is responsible for most of the critical notes; some of these are written in the first person, others have Ed. appended to them, but most of them are inserted without any special indication of their origin.

A complete list of all printed papers and books dealing with the Flora of Glamorgan will, it is hoped, be added at the end of the work. The following is a list of the abbreviations used for the more important of them consulted in the compilation of the first part.

B.G. The Botanists' Guide through England and Wales. By Turner \& L. W. Dillwyn, I805.

L.W.D.Mat. Materials for a Fauna and Flora of Swansea and the neighbourhood. By L. W. Dillwyn, Swansea. I848. Not published.

T.B. Topographical Botany. By H. C. Watson. 2nd Edition. I883.

J.S. The Flora of Cardiff. By John Storrie, I886. 
J.S.(2). Manuscript notes prepared for the 2nd Edition of The Flora of Cardiff.

Phyt. The Phytologist.

J. of B. Journal of Botany.

T.B. J.B.Supp. Topographical Botany. Supplement to and Edition. Published in Journal of Botany, I905.

Flora Rhondda. The Flora of the Rhondda. By Henry Harris, I905.

With. Bot., Withering's Arrangement of British Plants, I8I8. 6th Edition.

J.E. Notes made by Rev. J. Evans, Llandough, I83I.

Such general conclusions as may be drawn from the distribution of plants in Glamorgan, and their relations to the Flora of the surrounding counties and of the Continent will find a fitting place at the close of this work, when all the materials have passed through the hands of the Editor. The first five instalments will therefore, as outlined above, be devoted solely to the citation and distribution of the species of plants occurring in a wild state in the County of Glamorgan. Ballast plants will receive little or no attention unless they have succeeded in thoroughly establishing their claims to at least the status of an alien.

A. H. TROW.

UNiversity COLlege,

CARDIFF, December, Igo6. 


\section{Ranunculaceæ.}

\section{Clematis, Linn. I.}

I. Vitalba, Linn. Traveller's Joy or Old Man's Beard. Cúdll y coed. Dringiedydd.

Glamorgan name :-Trippa y Gwr drwg.

Local. Frequent. Native. Septal and sylvestral.

Common. J.S. Abundant in the Vale of Glamorgan. Apparently absent in the northern half of the County. "Ascends to 500 feet on the Little Garth, and 700 feet E. of Craig Llanishen." T.H.T. Walnut Tree! Leckwith! Llandough! Penarth! Sully! Dinas Powis! Barry! St. Donats ! Castell Coch. V. Llandaff ! St. Fagans, I. Porthkerry! B. Barry District. D. Merthyr Mawr. Miss B. Woods outside Roath Park. $P$. Not around Aberdare. $W$. Coedriglan. G.T. Gower. S.

\section{Thalictrum, Linn. 2.}

The species of this genus present great difficulties. The best authorities do not seem to have solved them. Four distinct forms have been found in Glamorgan, and these are grouped provisionally as follows:-

Thalictrum minus $L$. Lesser Meadow-rue. Arianllys bychan. Recorded from the Northern border of the County. L.W.D.Mat.

3. (a) dunense, Dum. ! !

Local. Abundant. Native. Glareal.

Llanmadoc, Gower. $V$.

(b) montanum, WalIr. A. y mynydd.

Rare. Scarce. Native. Rupestral.

Porthcawl ! ! In I89I and 1905. Either Southerndown or Porthcawl. $V$.

Thalictrum majus, $S m$. A. mwyaf.

4. (a) collinum, Wallr.

Local. Abundant. Native. Rupestral.

This plant is found only at elevations of about 1500 feet on wet rocks facing north and north-east. Craig-y-Llyn ! I 892 to 1905. Cwm Parc, Treorky! I898. Craig-y-Llyn, as T. minus. J.S. (2) and $W$.

\section{Thalistrum flavum Linn.}

7. flavum, Linn. Common Meadow-rue. A. cyffredin. Troed y barcud.

Local. Scarce. Native. Paludal.

Ewenny Bridge. $V$. Shewell. M.A.D. 
Anemone, Linn. 3 .

9. nemorosa, Linn. Wood Anemone. Frithogen, Blodeuyn y gwynt. Gwyntai.

Common. Abundant. Native. Sylvestral.

Flowers, varying in colour from white to light purple.

\section{Ranunculus, Linn. 6.}

The Editor is specially responsible for the critical forms of this genus. Many of the records furnished by correspondents for the various forms of the Batrachian Section (Nos. I4 to 24) are too doubtful for insertion.

14. circinatus, Sibth.

Rare. Scarce. Native. Lacustral.

Ditches, Newport Road, etc. J.S. Crymlyn Burrows and about Neath. Flower \& Lees, Phyt. I843. p. 377. Gutch Cat. T.B. Recent records are desirable.

\section{5. fluitans, Lam.}

Local. Abundant. Native. Lacustral.

Common; Taff, Ely and Rumney Rivers, etc. J.S. Ely River, St. Fagans! Cardiff Feeder, Specimen in Nat. Museum for Wales.

V. Ely River. G.T.

\section{7. trichophyllus, Chaix.}

Local. Abundant. Native. Lacustral.

Grangetown Brick Ponds!! Sully Moors Brick Pond!! Kenfig Pool ! ! As Ranunculus diversifolius on authority of F. A. Lees. J.B. Supt. 1905. Upper Grangetown, Saltmead, 1882. J.S. (2) Ewenny Wood, I877. Specimen in Nat. Museum for Wales? V.

18. Drouetii, Godr.

Local. Abundant. Native. Lacustral.

Near Cardiff Gas Works ! ! Near Lime Kilns, Llandough ! ! Lavernock !! Penylan Road, Cardiff ! Leys ! Nash !

19. heterophyllus, Web. ex. p.

Native. Lacustral.

Llandaff and Pencisely, 1877. $V$. Specimen in Nat. Museum for Wales. The Editor has not seen the plant. Other records are given under this name as an aggregate for plants almost certainly belonging to the species R. peltatus, Schrank.

20. peltatus, Schrank.

Local. Abundant. Native. Lacustral.

Lavernock Pond ! ! Pond near St. Fagans ! ! Welsh St. Donats! Hensol ! Kenfig Pool ! The form from Kenfig Pool is regarded by $\mathrm{Mr}$. Bennett as intermediate between R. elongatus, Hiern. and R. peltatus, Fries. Mr. Bennett also recognises R. floribundus, Bab. among the specimens submitted to him. The Editor finds several forms of this sub-species, especially in the Hensol area. 
21. Baudotii, Godr.

Local. Abundant. Native. Lacustral.

Recorded as frequent under R. confusus. J.S. Brick Ponds, Grangetown !! Brick Pond, Sully !! A peculiar variety occurs on the Pengam Moors which Mr. Bennett has not been able to name. It is much earlier and less robust than the typical R. Baudotii, and differs from those weak forms of R. Baudotil which grow in shallow water.

22. tripartitus, DC.

Rare.

Grange and Pengam Moors. J.S. and T.H.T. Recent records are very desirable for this plant. The Editor has searched the localities mentioned several times in vain.

23. Lenormandi, F. Schultz.

Local. Abundant. Native. Paludal.

East Moors, St. Fagans, Grangetown, Penarth, Pontypridd, as R. coenosus. J.S. Pontypridd!! Aberdare, Hirwain. $W$. Rhigos! Merthyr District. $F$. Barry District. $B$.

24. hederaceus, Linn. Crafangc y fran eiddewddail.

Common. Abundant. Native. Paludal.

25. sceleratus, Linn. Celery-leaved Crowfoot. C. yr eryr.

Common. Abundant. Native. Paludal.

27. Flammula, Linn. Spearwort. Poethflam. Blaen y gwaew lleiaf. Common. Abundant. Native. Paludal.

30. Lingua, Linı. Great Spearwort. B. y g. mwyaf.

Local. Abundant. Native. Paludal.

Near Coedriglan. Mrs. Traherne. On Crymlyn Bog and the margin of Kenfig Pool. L.W.D.Mat. On Crymlyn Bog and the Neath Canal in great abundance; also at Kenfig Pool. Gutch in Phyt. 1842. p. I05. Tennant Canal, Swansea. Cardiff Museum Specimen, Conway Collection, July, I834. Penmark, in E. Ddaw, in great abundance in 1898 ! Ystradowen! M.A.D. and $V$. Cowbridge Mill Stream, I882. J.S. (2). Dymbwdd Valley. Miśs B. Naturalized in Roath Park Brook in Botanical Gardens ! P. Merthyr District. $F$.

31. auricomus, Linn. Goldilocks. Peneuraidd.

Local. Abundant. Native. Septal and sylvestral.

Rare. Woods, Caerau and Melingriffith. J.S. Common in the Penarth area:-Penarth ! Michaelston-le-Pit ! Dinas Powis ! Sully! St. Mary Church Road! Porthkerry! Peterston Road. V. Fairwater. $V$. and $I$. Pentrebane Quarry. M.A.D. Llantrithyd. G.T. and H.E. The corolla in Glam. specimens is always more or less imperfect.

32. acris, Linn. Meadow Buttercup. Crafangc $y$ fran syth. C. boethus y gweunydd. C. ysol.

Common. Abundant. Native. Pascual. 
33. repens, Linn. Creeping Buttercup. C. y f. ymlusgaidd.

Common. Abundant. Native. Pratal, pascual, agrestal, and viatical.

34. bulbosus, Linn. Bulbous Buttercup. Chwys Mair, Blodau yr ymenyn.

Common. Abundant. Native. Pascual.

35. Sardous, Crantz. Hairy Buttercup. C. y f. blewog.

Local. Abundant. Native. Inundatal.

Marshy field between Swansea and St. Helens. B.G. and L.W.D.

Banks of the River Ddaw near Flemingston ! ! 1905. Near Llandough ! ! 1905.

36. parviflorus, Linn. Small-flowered Buttercup. C. y f. manflodeuog.

Local. Abundant. Native. Agrestal and glareal.

Frequent on the coast from Sully to Southerndown. J.S. Barry

Island. $V$. Southerndown. $V ., I$. and Miss B. Southerndown to Loughor. T.H.T. Ely. M.A.D. Common near Porthkerry. N. Sully ! G. Tresillian. G.T. Flat Holm! Rhoose and Aberthaw ! abundant. Barry. H.E.

37. arvensis, Linn. Corn Crowfoot. C. y f. yr yd.

Local. Scarce. Colonist. Agrestal.

Rare in Cornfields at Caerphilly. J.S. Single specimen on Penrhys Farm. Flora Rhondda. In cornfields ahout Newton and also near Caswell Bay. Flower \& Lees in Phyt. I843. p. 377. Porthcawl. Cardiff Museum Specimen, Storrie Collection. A few specimens in a cornfield, Barry District. $B$. Fairly plentiful at one time in the allotment gardens adjoining Ninian Road. $P$. Still cultivated at Roath Park Botanical Gardens !

Glamorgan names for the larger Rununculi in general are Blodeu ymenyn and Ohwys Mair.

39. Ficaria, Linn. Lesser Celandine. Llygad ebrill, Bronwys, Melyn y gwanwyn.

Common. Abundant. Native. Septal, etc.

\section{Caltha, Linn. 7 .}

40. palustris, Linn. Marsh Marigold. Troed yr ebol. Rhuddos y gors.

Common. Abundant. Native. Paludal.

\section{Trollius, Linn. 8.}

42 europæus, Linn. Globe flower. Cronell. Olbrain. Peneuraid. Local. Abundant? Native. Pratal or paludal.

Frequent in Ely, Taff, and Rhymney Valleys; St. Fagans, Pwllypant, etc. J.S. Between Pont-Nedd-Fechan and Usgoed Eynon Gam. Mr. J. Woods, innior. On the banks of the river, above the waterfall at Aberdylais; in moist meadows between Pont-NeddFechan and Usgoed Eynon Gam, and in similar dells about 
Ystradgynlais. L.W.D.Mat. 1848. Copied apparently trom Gutch in Phyt. 1842. p. I05. These localities are partly at least in Breconshire. Near Cefn Mably, 1876. Cardiff Museum Specimen. Aberdare, Hirwain, Rhigos. $W$. Merthyr District. $F$.

\section{Helleborus, Linn. 9 .}

44. foetidus, Linn. Bear's-foot. Crafangc yr Arth.

Local. Scarce. Native. Sylvestral.

There is some doubt as to the status of this species, and Watson places it among the denizens. It is well known in Glamorgan as a vermifuge and consequently often grown in gardens. Its occurrence in the wild state in and about thickets and copses gives it the appearance of a true native.

Near Park Mill towards Pennard Castle by Swansea. Dr. Turton. (B.G.) I805. Existing in great abundance in Dr. Turton's locality. Gutch in Phyt. 1842. p. I05. In hedges south of Park Mill, plentiful. Dr. Turton's locality. L.W.D.Mat. Sully !, Dunraven, St. Hilary. J.S. In a copse east end of Kenstone Farm House, Llancarfan. March, I83I. Abundant. J.E. Sully House Copse! V., $B$. and G. Dunraven. $V ., I$. , Miss B. and M.A.D. St. Hilary. G.T. St. Fagans! 1906. Miss Mabel Howell.

\section{Aquilegia, Linn. II.}

46. vulgaris, Linn. Common Columbine. Madwysg. Troed y ceiliog or $\mathrm{T}$. $\mathrm{y}$ golomen.

Local. Abundant. Native. Septal and sylvestral,

Hedge-rows near Mincian Hole (Gower) with white, blue and pink flowers. Gutch in Phyt. 1842. p. 105. Frequent. At Llanishen! Lisvane! Taffs Well! Tongwynlais! etc. J.S. Llanishen, Llantrisant, Tongwynlais, and Lisvane. V Fairwater, Tongwynlais, 1904. $I$. Porthkerry. B. Creigiau, Llantwit Vardre. D. Southerndown. Miss B. Radyr, Pentyrch. M.A.D. Llanishen. $P$. Taffs Well, Creigiau. $W$. Coedriglan. G.T. Near Caerphilly. F. Cwrt-yr-Ala, Dinas Powis! St. Fagans! St. Lythans! St. Hilary! Pencoed! Bridgend! Pwlldu, Gower! I892. Llangan! 1906. From Rhymney River, opposite Machen, to Taffs Well. Dinas Powis and Gower. S.

\section{Aconitum, Linn. I3.}

48. Napellus, Linn. Monkshood. Bleidd-dag. Cwcwll y mynach. Local. Abundant. Native. Sylvestral.

The status of this plant has been called in question, especially by Mr. Watson, who places it among the denizens. Had this botanist ever examined the banks of the river Ely from Ely to Llantrisant, I venture to think he would have given the species the rank of a native, to which on account of its mode of occurrence in this country and its distribution on the continent, it seems thoroughly entitled. 
"In Nicholaston Wood and the Woods at Penllergaer; and though there can be little doubt of a garden origin, it has flourished in both places time out of mind." L.W.D.Mat. Abundant on bushy ground near Llantrisant. Woods, in Phyt. 1850. p. I060. Common in the Ely ! Taff and Rhymney Valleys. J.S. The Ely River locality is now well known, as the plants may be seen and recognised for miles from the G.W.R. line whether in leaf in spring or in flower in summer. Ely River! V., I., T.H.T., Miss B., M.A.D., G.T. and $F$. Roath Park Brook ! where the plant was abundant before the construction of the Park. $V$. and $P$. Copse at Sully! $G$. No doubt planted here. Llanishen. $V$. and $D$. The distribution on the Taff and Rhymney is doubtful, and detailed information is desirable in view of Mr. Storrie's statement that the plant is common there.

\section{Pæonia, Linn. I5.}

50. corallina, Retz. Pæony. Blodau'r Brenin.

Rare. Scarce. Denizen? Rupestral.

Very rare. J.S. The status of this plant is very doubtful. It was first added to the British Flora by F. B. Wright in 1803 . Phyt. I843. p. 616.

"It was nearly eradicated in 1834 by destructive visitors from the British Association, meeting at Bristol." Cybele Britannica. Vol. I. p. 99.

Cardiff Museum Specimen. Leaf only. Steep Holm, I877. Storrie Collection. This station was examined by the Editor about the year 1896, when a clump of perhaps thirty good specimens, surrounded by a few scattered individuals, grew on the very edge of the cliff. They did not seem in great danger of extermination. Two specimens were secured for the Roath Park Botanical Garden, where they flourished for two or three seasons, and then died out. Mr. T. H. Thomas, who saw the plants in I904, says, "Perhaps increasing, as it seemed to me through an opera glass." The Steep Holm is in Somerset.

\section{Berberideæ.}

\section{Berberis, Linn. I 6.}

51. vulgaris, Linn. Barberry. Pren melyn.

Rare. Scarce. Denizen. Septal.

St. Nicholas and near Flemingston! J.S. and S. Rare, wild, in Rhondda. Flora Rhondda. Near Gigman Bridge. J.S. (2) Bank of River Taff above Llandaff, I 877. V. Hedge near Margam. T.H.T. Candleston Wood, Merthyr Mawr. E.V. and Miss B. All planted or escapes from cultivation. 


\section{Nymphæaceæ.}

Nymphæa, Linn. 18.

53. Iutea, Linn. Yellow Waterlily. Bwltys. Lili melyn y dwr.

Rare. Scarce. Native. Lacustral.

Cwrt-yr-Ala, Coedriglan, Llyn Fawr and Llyn Fach. J.S. Penrice. S. Penllergaer. G.T. "Not seen in this neighbourhood." i.e., in Llyn Fawr and Llyn Fach. W. No authority is given in Topographical Botany. The eviaence so far goes to prove that it occurs only where planted, in such localities as Penllergaer, Coedriglan, and Cwrt-yr-Ala.

\section{Castalia, Salisb. I9.}

55. speciosa, Salisb. White Waterlily. Alaw, Magwyr wen.

Local. Frequent. Native. Lacustral.

Crymlyn Bog in abundance. Gutch in Phyt. I842. p. 105. Civrt-yr-Ala, Coedriglan, Llyn Fawr and Llyn Fach. J.S. Porthkerry Park, I882. J.S. (2). Mr. Tennant's Canal, Crymlyn Burrows, I 832. J.E. Llyn Fawr, Vale of Neath Canal. W. Ely Valley. G.T. Kenfig Pool! abundant, 1905. Hensol! Penrice and Penllergaer. S.

\section{Papaveraceæ.}

Papaver, Linn. 20.

57. Rlıæas, Linn. Field Poppy. Pabi yr yd. Llygad y cythraul.

Local. Frequent. Colonist. Agrestal.

Penylan, Coedygoras, etc. J.S. Southerndown, Fairwater. E.V. Barry District. B. and D. Cornfields around Southerndown. Miss B. Aberdare, Hirwain. W. Coedriglan. G.T. Frequent in cornfields over the County, but less so than P. dubium. T.H.T. Aberthaw ! Penarth ! Cornfields and roadsides throughout Gower. $S$.

58. dubium, Linn. Long Smooth-headed Poppy. P. hir-benllyfn.

Local. Frequent. Colonist. Agrestal.

Not common. Leckwith, etc. J.S. Llantwit Major, Barry Island. E.V. Frequent over County. T.H.T. Llandough! Penarth!

59. Argemone, Linn. Long Rough-headed Poppy. P. hirbengwrychog.

Local. Frequent. Colonist. Agrestal.

In the cornfields about Swansea, frequent. Flower \& Lees in Phyt. I 843. p. 377. Aberdare. W. Frequently on the ballast at Cardiff, Penarth!, and Barry! J.S, and $B$.

Poppies of all kinds are comparatively rare in the cornfields of Glamorgan. 


\section{Meconopsis, Vig. $2 \mathrm{r}$.}

61. cambrica, Vig. Welsh Poppy.

Local. Frequent. Native. Rupestral and sylvestral.

Neath Valley, near Hirwain. Common, I882. J.S. (2) Vale of Neath, on bank of Perddyn, I897. T.H.T. Peterston-sup.-Ely. $J$. J. Neale. Banks of the Dulais. G.T. Morlais Castle. F. About Pont-Nedd-Fechan, Aberdylais, etc. Plentiful. B.G. "On the banks of the Dylais above Aberdylais, and at the waterfalls about Pont-Nedd-Fechan, plentiful. L.W.D.Mat.

\section{Glaucium, Hall. 22.}

62. flavum, Crantz. Horned Poppy. Llwydlas.

Local. Abundant. Native. Littoral.

Seashores, frequent. Penarth, Barry! Leys ! etc. J.S. Gileston ! 1903. Sully Island! I887. C.T.V. Sully Island! I., G. and H.E. The Leys! $B$. Port Eynon and sand-hills at Llangenneth, Gower. T.H.T. Newton Bay and Swansea Bay. Miss B. Sully ! Leys! and Worms Head. M.A.D. Monknash. G.T.

\section{Chelidonium, Linn. 24 .}

65. majus, Linn. Common Celandine. Dilwydd felen. Llysian'r wenol.

Glamorgan name :-Gwell na aur.

Local. Frequent. Denizen. Septal and viatical.

Common. Llandaff, St. Fagans ! Lisvane, Pencoed, etc. J.S. Lisvane, Llandaff, Ely, Cyntwell. $V$. Fairwater. $I$. Frequent about Barry. B. Llangynwyd, Bettws. T.H.T. Barry District. $D$. Merthyr Mawr, Miss $B$. Near Fairoak Farm, Roath. $P$. Aberdare, Hirwain, etc. W. Lower Penarth! G. Merthyr District. F. Michaelston-le-Pit!

\section{Fumariaceæ.}

Neckeria, Scop. 25 .

66. bulbosa, N.E.Br.

Rare. Scarce? Alien. Sylvestral.

Seems quite naturalized near Cottrell. Ioth April, 1892. J.S. (2).

67. Iutea, Scop. Yellow Fumitory.

Local. Frequent. Alien. Rupestral.

Southerndown! Miss F. Vachell, J.S., I., D., Miss B., M.A.D. and $N$. Well established and thriving. Merthyr Mawr. B. Ilston, Gower, and near Bridgend. T.H.T. Wenvoe ! I890. Trallwm, near Llanilid! I906. St. Fagans and Penmark. H.E. 
68. claviculata, N.E. Br. White Climbing Fumitory.

Local. Scarce. Native. Rupestral and sylvestral?

Rare. St. Fagans, Pwllypant, near Wenvoe. J.S. Boverton, I882. J.S. (2). Near Gwaelodygarth. $V$. and M.A.D. Merthyr Mawr. Miss B. Merthyr District. $F$. Absent from north border of Glamorgan, but occurs near the south border of Breconshire. IV.

\section{Fumaria, Linn. 26.}

This genus is not well represented in this County. Fumitories are seldom seen as prominent weeds. They require careful study. No local botanist has apparently even endeavoured to distinguish the segregates of Fumaria capreolata L. although they were recognised by Babington in the $5^{\text {th }}$ edition of his Manual published in $\mathbf{I} 862$. The records of the aggregates and segregates, meagre as they are, must therefore be given separately.

Fumaria capreolata L. Ramping Fumitory. Mwg y ddaiar afreolys. Glamorgan name:-Pwff y ddaiar.

An aggregate species made up of the segregates Nos. 69, 70, 71 and 72 of the London Catalogue.

Common by roadsides between Ferry and Port Tennant. Gutch in Phyt. I842. p. I05. "Though rare about London is more common than F. officinalis" in the neighbourhood of Swansea. L.W.D.Mat. Frequent. Llandaff, Penarth, etc. J.S. and T.H.T. Fairly frequent. Barry District. Southerndown. Miss $B$.

69. pallidiflora, Jord.

Reported by Babington. Linnaan Journal of Proceedings, Fet. 1860, according to Phytologist, I860.

71. confusa, Jord.

Reported in supplement to Topographical Botany. Joumal of Botany, 1905, on authority of E. F. Linton.

\section{2. muralis, Sonder.}

Reported along with 7 I on authority of the same Botanist.

74. officinalis, Linn. Common Fumitory. Mwg y ddaiar cyffredin. Local. Abundant. Native. Agrestal.

Common in cultivated ground and about hedges near Swansea. Flower \& Lees in Phyt. 1843. p. 377. Not so common as F. capreolata in Swansea District. L.W.D.Mat. Frequent. Penarth ! Llandaff, etc. J.S. and T.H.T. Not common. Penrhys and Blaenycwm. Flora Rhondda. Llantwit Major ! ! 1905. Fairwater. I. Barry District. $B$. and $D$. Southerndown. Miss $B$. Llandaff. M.A.D. Common garden weed (around Cardiff). $P$. Lavernock, Sully. G. Merthyr District. F.

\section{6. parviflora, Lam.}

Reported in the supplement to Topographical Botany. Journal of Botany, 1905, on authority of Cardiff Museum Strecimen. This specimen was almost certainly collected on the ballast at Cardiff, and the record is therefore of little value. 


\section{Cruciferæ.}

\section{Matthiola, R.Br. 27.}

77. sinuata, R.Br. Sea Stock. Murwyll towbannog arfor.

Rare. Scarce. Native. Littoral.

Frequent about Swansea and on the shores of this County. B.G. In I 802 , it was plentiful on the sand-hills between Swansea and the Mumbles, but has now become rare. It grows also sparingly on the sea-side, between the Eastern Pier and the Crymlyn Burrows. L.IV.D.Mat. On the sand-hills between Swansea and the Mumbles. also on the sea-side of Crymlyn Burrows. Gutch in Phyt. I842. p. I05. There appear to be no recent records for this plant.

78. incana, R.Br. Hoary Stock.

Rare. Scarce. Native. Littoral.

This plant apparently occurs on one almost inaccessible cliff on the coast of Glamorgan, to the east of Sontherndown, and is therefore not to be confused with the plants recorded from the neighbourhood of Swansea in the preceding note. The locality has been known to the Rev. IV. F. Evans, The School, Cowbridge, for some time. The plants were shewn to me in I900 or I901 by my pupil, Mr. I. Buller Pole-Evans, and two specimens were obtained with difficulty. These and their offspring flourished in my garden at Penarth for three seasons, and then were lost through the seedling plants being eaten up by slugs. The plants resembled the Brompton stocks of our gardens very closely, and changed colour under cultivation in the second or third generation, perhaps as the result of crossing. They were not at all like examples of $M$. sinuata collected on the opposite coast of Devonshire. There were perhaps a hundred plants in flower in the original locality on April I6th, I906, all inaccessible except to an expert cragsman provided with ropes. The colour was of a uniform reddish purple, without any of that variability observed in the specimens raised in my garden.

Cheiranthus, Linn. 28.

79. Cheiri, Linn. Wallflower. Melyn y gauaf, Murwyll.

Local. Frequent. Alien. Rupestral.

Frequent. Cardiff Castle, Llandaff, Peterston, etc. J.S. Ogmore Castle WValls! Old Bishop's Palace, Llandaff. V. St. Fagans! I. On most old or ecclesiastical buildings throughout the County. T.H.T. Barry Castle. D. Ogmore Castle. Miss B. Llandaff. M.A.D. Old wall of Ladies IValk, Cardiff Castle. $P$. Llantwit Major ! abundant. On cliffs at Nash Lighthouse ! Park Mill, Gower. S.

Nasturtium, Linn. 29.

8o. officinale, R.Br. Watercress. Berwr y dwr. Common. Abundant. Native. Paludal. 
81. sylvestre, R.Br. Creeping Watercress.

Local. Abundant. Native. Paludal.

Common. Ely, Leckwith, etc. J.S and T.H.T. Frequent. Flora Rhondda. Penarth Road ! V. Llandaff ! $I$. Common at Dock and roadsides at Penarth ! $B$. Barry District ! D. Canal Banks, Llandaff. Miss $B$. Vale of Neath. W. Leckwith! Flemingston Moors! Treforest! Taffs Well ! very abundant.

82. palustre, DC. Marsh Watercress.

Local. Abundant. Native. Inundatal.

Common. Ely, St. Fagans, etc. J.S. and T.H.T. Common. Flora Rhondda. Roath Park. $V$. Barry District occasionally. $B$. Marcross, M.A.D. Aberdare Valley. $W$. Leckwith ! Cadoxton Moors ! St.-y-Nyl ! Penarth Streets! at foot of trees along with N. sylvestre. Llandough ! Lavernock !

83. amphibium, R.Br. Great Watercress.

Rare. Frequent. Native. Paludal.

Penarth Road, first noticed by J. McCulloch in I893. J.S. (2).

Canal Bank, Llandaff, July 5th. I905. Miss $B$. Flemingston Moors! 1905 .

\section{Barbarea, R.Br. 30.}

84. vulgaris, R.Br. Yellow Rocket. Berwr y gauaf. B. Caersalem. Local. Frequent. Native. Viatical.

Frequent. Penylan, Llanishen, etc. J.S. Frequent. Flora Rhondda. Very plentiful near Ely Bridge. J.S. (2). Barry Island. $V$. and $I$. Frequent in moist hedgerows in Barry District. $B$. Walnut Tree. M.A.D. All over district? $P$. Common. W. Very abundant on the banks of the brooks and reens on the Sully and Cadoxton Moors! Penarth ! St. Fagans !

\section{8. praecox, R.Br.}

River Ogmore? Miss $B$.

\section{Arabis, Linn. 3I.}

93. hirsuta, Scop. Hairy Rockcress. Twr-ged blewoy.

Local. Frequent. Native. Rupestral.

Walls of Oystermouth Castle. B.G. Walls of Oystermouth Castle and about Park Mill. Also found on the sand-hills at Kienfig by Mr. Motley. L.W.D.Mat. Same record in effect as that of Gutch. in Phyt. I842. p. 105. Rare. Near Llanblethian. North Road, Cardiff. J.S. St. Hilary and Cowbridge Cattle Market. J.S. (2). Rare. Ruins at Tyntala. Flora Rhondda. Aberdare, Hirwain, etc. W. Merthyr District. F. Cold Knap, Barry! 1905. Dinas Powis! 1905. Southerndown Road! I898 to 1905. Porthcawl Dunes. $N$. 


\section{Cardamine, Linn. 32.}

96. amara, Linn. Large Bittercress.

There is a very doubtful record for this plant. In the supplement to the and edition of Topographical Botany, published in the Journal of Botany for 1905 , it is recorded on the authority of a specimen in the Cardiff Museum. The specimen is a genuine specimen of C. amara no doubt, and is labelled Pontypridd, July, 1877. Storrie Collection. Storrie, however, did not include this interesting plant in the Flora of Cardiff published in 1886 , and we may therefore almost certainly conclude that he had doubts himself about the record.

97. pratensis, Linn. Ladies' Smock. Hydyf y waun.

Glamorgan name:-Esgiđiau hosanau y gôg. (Pron. 'Sgitsiasana-gôg.)

Common. Abundant. Native. Pratal and paludal.

98. hirsuta, Linn. Hairy Bittercress. Hydyf blewog.

Common. Abundant. Native. Rupestral.

\section{9. flexuosa, With.}

This plant is not always distinguished from the preceding one, although in Glamorgan the two species are always well defined. It grows in damper, more shady places than C. hirsuta, is more robust and flowers later. Common. Penylan! Llandaff, etc. J.S and T.H.T. Aberdare, Hirwain, Vale of Neath ! W. Cwrt-yr-Ala! Dinas Powis ! Gwaelodygarth ! Taffs Well !

100. impatiens, Linn. Narrow-leaved Bittercress.

Rare. Probably scarce. Native. Rupestral.

Gathered by Mr. Moggridge at Coed Cymmer near Merthyr Tydfil. L.W.D.Mat, and G.T. Rare. Coed Cymmer, Quakers Yard. J.S. There are no recent records for this interesting plant.

\section{Draba, Linn. 34.}

Nos. I05 and I07 have been recorded each by a single corres. ponding member of the Committee, the first from Southerndown and the second from near Wenvoe. The first may be a correct record, but requires confirmation. The second is almost certainly erroneous.

\section{8. aizoides, Linn.}

Rare. Scarce. Native. Rupestral.

Walls and inaccessible rocks about Pennard Castle, eight miles west of Swansea. Dr. Turton. Frequent also on the rocks about the Worms Head. B.G. "Was first noticed on the old walls of Pennard Castle, by the late Mr. Lucas, of Stouthall, who communicated his discovery to Dr. Coyte, of Ipswich. The plant was afterwards shewn by Mr. Lucas to Dr. Turton, and the latter sent the specimen to Sowerby, which has been figured in English Botany. It grows also on most of the higher cliffs, and in many inaccessible places along the coast from Pennard to Worms Head." L.IV.D.Mat. This note was first published by Gutch in the Phytologist, I842. pp. 105-6. It occurred in plenty on the walls and adjacent rocks 
at Pennard in 1892 . (Editor.) Mr. Illtyd Buller Pole-Evans, who knew the plant well, tells me that it still occurs all along the Gower coast from Pennard to the Worms Head. Paviland caves to Worms Head and Pennard Castle. S. "It appears ... to have been found as long ago as in the year I795 by John Lucas, Esq., of Stouthall, growing near Worms Head sixteen miles west of Swansea." Withering's Botany, I8 8 .

\section{Erophila, DC. 35 .}

109. vulgaris, DC. Whitlow grass, Llys y bystwm.

Local. Abundant. Native. Glareal.

Not common. On walls at Roath. Coedriglan. J.S. Frequent. Mid Rhondda, Porth, Blaenycwm. Flora Rhondda. Caerphilly Common and Southerndown! $V$. St. Fagans. I. Barry Island ! Porthkerry! Leys. B. Seems to be "frequent" all over the County, "not common." T.H.T. Barry District. D. Ogmore! Miss B. Caerphilly Common and Fairwater. M.A.D. Llantrithycl. G.T. Merthyr District. F. Dinas Powis Common! Cwrt-yr-Ala! Grangetown Marl Ponds ! Llandough ! Southerndown Road ! Drope. $H . E$. Always of one type, shewing no tendency to the production of distinct varieties or races.

\section{Cochlearia, Linn. 36 .}

II2. officinalis, Linn. Common Scurvy-grass. Morlwyau meddygawl.

Local. Abundant. Native. Littoral.

Banks of the Tawe, between Swansea and Landore, plentifully. B.G. Common. Penarth to Southerndown. J.S. Southerndown. $V ., I_{.}, M$ iss B. and M.A.D. Sully. G. Banks of the Tawe. G.T. Estuaries of the Rhymney! Taff! and Ely! This and its associated species C. anglica require detailed experimental study.

I 5. danica, Linn. Danish Scurvy-grass. Morlwyau Daniaidd. Local. Abundant. Native. Littoral.

Abundant on the rocks about the Mumbles Lighthouse and in similar situations on the coast. B.G. The same record as in B.G., with Gower Cliffs added. L.W.D.Mat. Near Singleton. Rocks near Mumbles Lighthouse! Oystermouth Castle. Gutch in Phyt. I842. p. I06. Not common. Llantwit Major! St. Donats! etc. J.S. and T.H.T. Barry Island ! Leys ! Aberthaw ! B. Boat House, Barry! D. Near Southerndown. Miss B. Barry Island! M.A.D. Sully! Porthkerry! Southerndown. N. Dunraven. G.T. Porthcawl! Kenfig!

1 17. anglica, Linn. English Scurvy-grass. Morlwyau brutanaidd. Local. Abundant. Native. Littoral.

Banks of the Tawe a little above Swansea. J. Woods, Junior. B.G. Frequent. Penarth, etc. J.S. General round coast. T.H.T. Leckwith Bridge. E.V. Barry Island, Leys, Aberthaw. B. Ogmore Estuary. Miss $B$. Banks of the River Tawe, near Swansea, May, 1903. Sowerby. A.B. Dunraven. G.T. Ely Estuary! 
18. Armoracia, Linn. Horse-radish. Rhuddygl mawrth. Local. Frequent. Alien.

Not common. About houses, Leckwith, St. Athan! Llantwit! etc. J.S. Southerndown. E.V. St. Fagans ! I. Barry Island. $B$. and D. Penclawdd, etc. T.H.T. Merthyr Mawr. Miss B. Common. W. Aberthaw! St.-y-Nil and Margam. S.

\section{Hesperis, Linn. 37.}

1 19. matronalis, Linu. Dame's Violet.

Local. Frequent. Alien. Septal.

Not common. Near Cardiff, St. Nicholas! Bonvilston, Ewenny Bridge, etc. J.S. and T.H.T. Fairwater. V. and I. Near Cwm Cidy Lodge, Barry. D. Llandaff. M.A.D. Cowbridge Road, near Llandaff. G.T. In great abundance in Roger Moor Wood, Penarth ! in 1902 and 1903 , immediately after the making of a new roadway through it. Coedriglan. H.E.

Sisymbrium, Linn. 38.

120. Thalianum, J. Gay. Wallcress. Berfain cyffredin.

Local. Frequent. Native. Glareal and rupestral.

Common. Penylan, St. Fagans, Penarth, etc. J.S. Llanbradach. $V$. and M.A.D. Colwinston. Miss B. Sully ! G. Merthyr District. $F$. Hirwain and Aberdare District-common. IV. Penarth! Barry Island! Taffs Well! The plant is not very common, indeed it is decidedly local in the south-east corner of the County.

I 2 . officinale, Scop. Common Hedge-mustard. Arfog meddygawl. Common. Abundant. Native. Septal and viatical.

123. Sophia, Linn. Flixweed. Piblys.

Local. Scarce. Alien. Viatical.

Waste ground about Infirmary (at Swansea). Flower \& Lees $2 n$ Phyt. I843. p.377. On ballast, frequent. J.S. Swanbridge Farm. 1902. V. Barry Dock Ballast. B. and D. Penarth Dock! Very abundant in $189 \mathrm{I}$ on both sides of the Ely. Persisted about timber stacks, etc., till 1905, when a few specimens were still to be seen.

125. Irio, Linn. London Rocket.

Occurs occasionally here and there, probably always from imported seed. Reported at Cardiff ! J.S. Penarth ! Aberdare. W. Coedriglan. G.T. and H.E.

126. Alliaria, Scop. Garlic-mustard. Garllegog. Troed yr assen. Common. Abundant. Native. Septal.

\section{Erysimum, Linn. 39.}

127. cheiranthoides, Linn. Treacle Mustard.

Rare. Scarce. Alien. Viatical.

On ballast at Penarth! J.S. Cathays Park and Ystrad Mynach. $V$. Barry, $B$ and D. Peterston. M.A.D. 


\section{Brassica, Linn. 42.}

131. oleracea, Linn. Wild Cabbage. Bresych.

Local. Abundant. Native. Littoral.

Plentiful on Barry Island. Woods in Phyt. 1850. p. 1060. Barry to Southerndown. J.S. Southerndown, Fontigary. $V$. Plentiful on cliffs around coast. $B$. Llantwit Major-very fine. T.H.T. Barry District. D. and M.A.D. Monknash. Miss B. The plant is so plentiful on several parts of the coast as to be regularly collected in hard winters for use as a vegetable. It occurs in great profusion, as Storrie says, from Barry to Southerndown, the rotten Lias cliffs, with their alternating bands of clayey shale and limestone suiting it admirably. Watson classes it as a denizen, but he had never seen this plant on our coasts. It is almost certainly a true native with us, or at any rate indistinguishable from one. There are no records from the Western half of the County, where the Lias rocks do not occur.

The next three species constitute a group of special difficulty even to those who have paid most attention to them. The Editor has grown one of the forms for two generations, and recognised three as occurring in the district. The nomenclature of the London Catalogue is, upon the whole, less satisfactory than that of Syme in English Botany. We shall therefore adhere to the latter. The aggregate species is named by Syme, B. polymorpha, and he reduces the three Linnæan species B. Napus, B. campestris. and B. Rapa to the rank of sub-species. Whether this grouping will stand the test of experimental culture remains to be seen; it will in the meantime best serve our purposes.

Brassica polymorpha:-aggregate species.

Most of the records are recognisable as distinctly referring to this aggregate species. It is recorded from most of the district, e.g. Merthyr, Aberdare, Hirwain. Coedriglan, Sully. Sometimes, however, it is confused with altogether different species, as when it is referred to as growing in "fields everywhere."

Brassica Napus, Linn. Rape.

Local. Frequent. Colonist. Viatical and agrestal.

Kilvey Hill, Common. Gutch in Phyt. I 842, p. I06. Frequent. Llandaff, etc. J.S. and T.H.T. Mr. Storrie, however, does not distinguish specifically between the wild turnip and the rape. Plentiful around Barry. B. Lavernock. M.A.D. Cathays Park, Cardiff ! in 1905 and 1906 along margins of new roads.

Brassica campestris, Linn. Wild Navew, the Swedish Turnip being a cultivated variety. Meipen yd.

Glamorgan name:-Erfinen wyllt.

Local. Frequent. Colonist, Agrestal and viatical.

The plant is often found along the margins of reens and streams in the Vale of Glamorgan. It is not only the commonest of the three sub-species, but in my opinion, the only one which can be said to really maintain itself in the wild condition. Most of the records under the aggregate species no doubt apply to this form. Dinas Powis! Sully! Cadoxton! Flemingston Moors! etc. 
Brassica Rapa, Linn. Wild Turnip.

No records. The third type recognised by the Editor as occurring in the district remains unidentified. It is probably a variety of the wild Navew.

135. monensis, Huds. Dwarf Walltower cabbage. Berwr mon. Rare. Scarce. Native. Littoral.

On the downs near Park and above Mincian Hole, three specimens gathered in 1838 and 1839 by Mr. Moggridge. Rocks and down near Pennard Castle. Gutch in Phyt. I842. p. I06. At Nicholaston, Gower. Woods in Phyt. 1850. p. 1060. Not common. Aberthaw. J.S. I have looked for it so often that I feel sure it does not now occur there. (Ed.) Inland at Merthyr Tydfil. Hooker's Flora. Confirmed recently by $F$.

\section{I36. Cheiranthus, Vill.}

No good records exist for this plant in a really wild state. The record in L.W.D.Mat. refers doubtless to Mr. Moggridge's plants mentioned under I 35. In T.B., J.B.Supp., Port Taîbot is given on the authority of Marshall. This is a record of a plant probably introduced with ballast. The species occurs regularly on the rajlway embankments about Penarth Docks and between Penarth and Cardiff !! It seeds and maintains itself for a time, but the number of individuals is always few.

137. Sinapioides, Roth. Black Mustard. Cedu du.

Local. Abundant. Native. Littoral, viatical, and agrestal!

Frequent. Cardiff! Barry! etc. J.S. Lavernock Cliffs! Swanbridge! $V$. Common round Barry! $B$. This plant is common on the Lias Cliffs from Penarth Head! to Southerndown! and extends inland to cultivated fields, occasionally proving as troublesome a weed as Nos. I 39 and 140.

I 38. adpressa, Boiss. Hoary Mustard.

This plant has little claim to inclusion. It used to be common as a ballast plant about Cardiff, Penarth, and Barry. It has maintained its hold at one spot near Barry! on sandy soil for at least six years, seeding freely and producing fresh crops.

I39. Sinapistrum, Boiss. Charlock. C. gwyllt.

Common. Abundant. Native. Agrestal.

I 40. alba, Boiss. White Mustard.

Local. Abundant. Native. Agrestal.

Rare, Penarth, Southerndown. J.S. Between Penhill and Canton, I830. J.E. This plant is so common that the Editor doubts whether it does not deserve to be recorded with the highest degree of frequency for the habitats as well as for the individuals. No records are, however, furnished by our correspondents, who possibly have not learned to distinguish it from the Charlock with which it is associated in our fields. It is often a common weed on the Lias near the coast. It occurs from Penarth to Southerndown. In my notes I find records for Penarth! Sılly! Hayes! Aberthaw! Llantwit 
Major ! and St. Donats ! It is so common, however, that one is apt to forget that it has been recorded as rare and looked upon as a doubtful native, and therefore its occurrence has not always been definitely noted. It is often more abundant than the Charlock in weedy cornfields in south-west Glamorgan.

\section{Diplotaxis, DC. 43.}

142. tenuifolia, DC. Narrow-leaved Wall Mustard.

Local. Abundant. Denizen. Viatical.

Near Llandur (Landore). Gutch in Phyt. 1842. p. 106. Frequent. Penarth, etc. J.S. Common. Flora Rhondda. Grangetown! on old ballast. $V$. Common at Barry! $B$. Barry District. D. Porthcawl ! and Ely Common! M.A.D. Sandy Shore at Porthcawl. $P$. and $N$. The plant has every appearance of having been originally introduced with ballast. It has established itself thoroughly in a great many places, but never occurs far from the original tipping places. It is very common on the embankments and waste places about Penarth!

143. muralis, DC. Sand Mustard.

Local. Abundant. Denizen. Viatical.

Plentiful about Swansea. B.G. "Very common on the sandhills, and by the roadsides, and almost everywhere about the town, except on walls." L.W.D.Mat. Frequent. Penarth ! etc. J.S. Common. Flora Rhondda. Common about Swansea. Woods in Phyt. I850. p. I060. Barry. I. Porthcawl! P. and N. Singleton. G.T. Caswell Bay! Llandough! Steep Holm ! This plant occurs mixed with the former species at Porthcawl, is relatively rare in the easterm half of the County, and relatively common in the western.

\section{Bursa, Weber. 44.}

144. Bursa=pastoris, Weber. Shepherd's purse. Llys tryfol. Purs y bugail.

Common. Abundant. Native. Viatical and agrestal.

\section{Coronopus, Rupp. 45.}

145. didymus, Sm. Lesser Wart Cress.

Local. Abundant. Native. Viatical.

Llandwr Marsh common. Cadoxton and Fabian's Bay. Gutch in Phyl. 1842. p. I06. Abundant about rubbish heaps and roadsides at Swansea. L.W.D.Mat. Common about Cardiff. J.S. In the Cardiff Museum there are specimens from Pwllypant (I877. A. Langley), and Mumbles (July, I834, Conway Collection). Bute Esplanade, Cathays Park. V. Fairwater. I. Leckwith. M.A.D. an $\vec{a}$. Southerndown. $N$. Abercynon. $W$. Coedriglan. G.T. and H.E. Penarth! Sully! Caswell Bay! 
146. Ruellii, All. Swine's Cress. Berwr y moch.

Local. Abundant. Native. Viatical.

Singleton Marsh. Gutch in Phyt. I842. p. I06. Not common. Plentiful at Cardiff Docks. J.S. Cardiff Docks. V. Barry District. D. Southerndown. M.A.D. Penarth ! Marcross ! St. Donats !

\section{Lepidium, Linn. 46.}

I 47. latifolium, Linn. Broad-leaved Pepperwort. Pybyrllys.

There is no good record for this plant. Marshes. St. Donats, etc. J.S. There are no marshes at St. Donats, and the plant has been searched for there in vain. In the Cardiff Museum there is a specimen marked Penarth, Augıst, 1876. This may be the plant on which Mr. Storrie based his record. The species does not now occur at Penarth. Llantwit Vardre is given on the recent authority of $D$.

148. ruderale, Linn. Rubbish Pepperwort.

Local. Abundant. Native. Littoral.

Ballast banks about Swansea. B.G. Occasionally on rubbish heaps and ballast banks about Swansea. L.W.D.Mat. Common. Bute Docks, Penarth, Barry, etc. J.S. Common. Flora Rhondda. Swanbridge Road at Cog Farm. Cardiff Docks. $V$. Barry. B. and $D$. Newton sand-hills. Miss $B$. Hirwain. $W$. Penarth ! Lavernock ! Grangetown! Barry! Caswell Bay! Found in great quantities in very fine condition near the Gas Works on the banks of the Taff, and sometimes sold when in fruit by the street hawkers of Cardiff for decorative purposes.

149. Sativum, Linn. Garden Cress. Berwr ffrengig.

Local. Frequent. Alien. Viatical.

Frequent. Roath, Newhouse, etc. J.S. Frequent as a casual. Came up regularly for several seasons in a new cinder path at Corner's Well Farm, Penarth ! Never seen really wild.

150. campestre, R.Br. Common Mithridate Pepperwort. Codywasg y maes.

Common. Abundant. Native. Agrestal and viatical, etc.

151. hirtum, Sm. Smooth Field Pepperwort.

Local. Frequent. Native. Agrestal and viatical.

Everywhere on the sea-shore near Swansea. Gutch in Phyt. 1842. p. I06. Pont-Nedd-Fechan and Pont Walby. Woods in Phyt. I850. p. 1058. Frequent. Cardiff, Penarth, etc. J.S. Frequent. Flora Rhondda. Pwllypant. E.V. Peterston. M.A.D. Barry. N. and G.T. Sully. G.

152. Draba, Linn. Whitlow Pepperwort.

Local. Abundant. Denizen. Viatical.

Found on the banks of the Tawe above Swansea, in 1802 , where ballast had been formerly deposited, and found higher up the river by Mr. Moggridge in 1840 . Writing in $1848, \mathrm{~L}$. W. Dillwyn declares it must have ripened its seed regularly for much more than half-a- 
century. Hence he regards it not only as "perfectly naturalized," but as much of a native as many plants which appear in our floras. Its natural range is " over France to the English Channel." L.W.D. Mat. Common about Cardiff Docks, etc. J.S. Common. Blaenrhondda to Porth. Flora Rhondda. Waste ground about Cardiff. $V$. Barry ! B. and $D$. Hirwain and Aberdare. $W$. Merthyr District. $F$. Penarth ! to Cardiff ! on railway embankments. Watson classes this species as an alien. The plant appears to furnish a case of a ballast plant which has adapted itself thoroughly to its new environment.

\section{Thlaspi, Linn. 47.}

153. arvense, Linn. Field Penny Cress.

Rare. Scarce. Colonist. Agrestal and viatical.

Wych Tree Bridge (Dillwyn). Gutch in Phyt. 1842. p. 106. By the roadside between Wychtree Bridge and Llangyfelach, and several other places. L.W.D.Mat. Llanishen. H.E. Rare. Temperance Town and occasionally on ballast. J.S. Cardiff Museum Specimens exist labelled Tyndall Street, Cardiff, 1877, Artillery Range, I877, Roath Park, 1892. Penarth Dock! probably on old ballast, I905. Cornfield near Dinas Powis Common! I Ith June, 1892. St. Hilary. G.T. Kymin! 1907.

155. alpestre, Linn. Alpine Shepherd's Purse.

Rare. Scarce. Native. Rupestral.

About Pont-nedd-Vechan and Aberpergwm. B.G. This locality is repeated in L.W.D.Mat. and by Gutch in Phyt., I842, and by G.T. Recent records accompanied by specimens are very desirable.

\section{Iberis, Linn. 48 .}

156. amara, Linn. Bitter Candytuft. Beryn chwerw.

Local. Scarce. Alien. Viatical.

Dusty Forge, Pontypridd. Outcast. J.S. On cliffs near Swanbridge, where it maintained itself for several years. The University College Herbarium has a specimen marked I891. Plant apparently extinct, I905.

\section{Teesdalia, R.Br. 49.}

I 57. nudicaulis, R.Br. Shepherd's Cress. Beryn coesnoeth. Local. Scarce. Native. Rupestral and glareal.

Not infrequent about Swansea. B.G. Occasionally found about the sand-hills and roadsides. L.W.D.Mat. Gutch in Phyt. I842, has the same note. Recent records are desirable as the plant does not seem to occur in West Glamorgan. The Editor has collected it on limestone rocks near Crickhowell, Breconshire, a district not included in Topographical Botany, 2nd edition. 


\section{Hutchinsia, R.Br. 50.}

I 58. petraa, R.Br. Rock Hutchinsia.

Walls of Pennard Castle. B.G. Walls of Pennard Castle ; Mr. Moggridge has found it on the rock north of the Castle. L.W.D. Mat. On walls of Pennard Castle; on sandy ground south of Pennard Castle on April 20th, 1839, by Mr. Moggridge. Pennard Castle ! G.T. In the University College Herbarium is a specimen collected by the Editor in I 892 from the walls of the Castle.

\section{Crambe, Linn. 52 .}

I60. maritima, Linn. Sea Kale. Ysgedd arfor.

Rare. Scarce. Native. Littoral.

Rocks about Port Eynon. Dr. Turton. B.G. On the sandy shore between the Neath and Afan Rivers. Gutch in Phyt. I842. p. 106. "On sand-hills nearly opposite Baglan, and is said in the Swansea Guide (1802, Flora by Dr. Turton) to grow on rocks about Port Eynon. Found by Mr. Motley between Sker and Porthcawl." L.W.D.Mat. Rare. Leys, St. Donats. J.S. Said to have occurred near the Summer House, Boverton. I. B. Pole-Evans. Not to be found in 1905. One seedling plant noted on beach at Sully! June, 1900. Occasionally at the Leys, B. Newton Sands, Porthcawl. Miss B. Near Neath. G.T. Gower, rare. $S$.

\section{Cakile, Linn. 53 .}

I6r. maritima, Scop. Sea Rocket. Hegydd y morlan.

Local. Frequent. Native. Littoral.

Frequent. Sully ! Barry !- Leys! J.S. All round Glamorgan coast. Frequent in Gower. T.H.T. and $S$. Barry Island ! Leys. $B$. Whitmore Bay. D. Newton Sands. Miss B. Barry. M.A.D. Porthcawl ! $P$. Aberthaw !

\section{Raphanus, Linn. 54.}

I 62. Raphanistrum, Linn. Wild Radish. Rhuddygl.

Local. Frequent. Colonist. Agrestal and viatical.

Frequent. Llandaff, Whitchurch, etc. J.S. and T.H.T. Southerndown. $M$ iss $B$. Very abundant about Grangetown ! and Penarth Docks ! The plant is commoner than appears from the actual records.

163. maritimus, Sm. Sea Radish.

Rare. Scarce. Native? Littoral.

Rare. Penarth, Aberthaw. J.S. Have looked many-times for it in vain in both places. (Ed.) Recorded in T.B., J.B. Supp., 1905, with reference to $J$. of Bot., 1888, p. 57. Sea-wall near Porthcawl. Miss $B$. Abundant along with other introduced plants near Ely River Wharves! in 1892 and on to 1905 . Modern records of this species in the truly wild condition are still a desideratum. 


\section{Resedaceæ.}

Reseda, Linn. 55 .

164. alba, Linn. Upright Mignonette.

Rare. Scarce. Alien. Viatical.

Below St. Hilary. Rare. J.S. Cogan Pill Ballast. $V$.

165. lutea, Linn. Wild Mignonette.

Local. Frequent. Native. Viatical.

Frequent. Ely, Caerphilly, etc. J.S. and T.H.T. Ewenny. Miss B. Walnut Tree! M.A.D. Porthcawl! P. Aberdare, Hirwain. $W$. Cowbridge. G.T. Penarth Dock! Lavernock! 189I. St. Fagans! Specimen in Cardiff Museum, T. H. Thomas Collection.

106. Luteola, Linn. Dyer's Weed. Melengu.

Common. Abundant. Native. Viatical.

\section{Cistineæ.}

Helianthemum, Hall. 56.

I 69. marifolium, Milı. Hoary Rock Rose. Cor rosyn lledlwyd.

Rare. Scarce. Native. Rupestral.

Cockit, in road leading to back of Uplands. Gutch in Phyt. I 842. p. I06. On Cefnbryn and the Worms Head, and on the latter it has been found with white flowers. L.W.D.Mat. Gower Cliffs. G.T. Merthyr District. F.

I 70. Chamacistus, Mill. Common Rock-rose. C. cyffredin. Common. Abundant. Native. Rupestral and pascual.

\section{Violarieæ.}

Viola, Linn. 57.

172. palustris, Linn. Marsh Violet. Gwiolydd y gors. Gwythdudd. Local. Frequent. Native. Uliginal.

Frequent in bogs. Llanishen, Duffryn ffrwd, etc. J.S. Fre. quent. Flora Rhondda. Pendoylan. $V$. and $I$. Common in bogs about the Vale of Neath and north-west area of the County. T.H.T. Ogmore. Miss B. Caerphilly Common! Garth! Cowbridge. M.A.D. Treorchy. N. Common in Hirwain area. $W$. Penllergaer. G.T. Merthyr District. F. Hensol ! Crymlyn Dingle ! Pontardulais ! Pennard and Park Mill, Gower, S.

173. odorata, Linn. Sweet Violet. Gwiolydd. Millyn gwyn. Meddygyn. Craith unnos.

Common. Abundant. Native. Septal and sylvestral. 
As Watson classes this with the denizens, it is as well perhaps to give its detailed distribution, notwithstanding the fact that the frequency of the species, both as to habitats and individuals is indicated by the highest terms. Frequent all over the district. J.S. Frequent. Flova Rhondda. Road from the Village to Penarth Church. J.E., I83I. Fairwater. I. St.-y-Nil. $V$. Plentiful but local, Barry district. $B$. Candleston. Miss B. Common. M.A.D. Sully. G. Coedriglan. G.T. Occurs in three colours, white, very common ; blue, frequent ; purple, rare ; at Llantrithyd-specimens collected by Professor Parker. Mr. T. H. Thomas reports that the blue flower is generally that of the lowlands and white that of the uplands. That is not the experience of the Editor. The species is very common in the Vale of Glamorgan, less so in the hill districts. The absence of records from correspondents in the Merthyr and Hirwain districts is noteworthy. 'The Editor's notes include the following specific localities:-Penarth ! Swanbridge ! Sully ! Barry! Llanharan! Llanilid! Llangan! Colwinston! Southerndown Road! St. Donats! the last with white and blue flowers and others of intermediate tint. G.T. records the hybrid with V. hirta.

1 74. hirta, Linn. Hairy Violet. Gwiolydd flewog.

Local. Frequent. Native. Septal, pascual and sylvestral.

Peninsula of Gower, not infrequent. B.G. Not uncommon in Gower, chiefly on the limestone. L.W.D.Mat. Frequent. Llanishen, Sully! Barry! J.S. Cogan. V. St. Fagans. I. Barry, Porthkerry! B. Castell-upon-alun. Miss B. St. Fagans, Cogan. M.A.D. Sully. G. Tresillian! G.T. This plant has a very large number of habitats in the County, but is seldom seen in quantity, and is often confused with other species, Dinas Powis ! Cwrt-yr-Ala ! Barry Island! Very abundant in I 892. Flat Holm! Lavernock! Llangan! Colwinston! St. Donats! Marcross ! Monknash !

Nos. I75, I76, and 178 are hopelessly mixed up by most of our correspondents under the name of Viola canina. No purpose would be served by giving the distribution of this common and abundant aggregate species. Our commonest "dog violet" is No. I76. No. I 78 is the "dog violet " of the sand-hills along the coast. No. I75 is the "dog violet" of our lanes with purple, bluntly pointed, unfurrowed spur, and small calyx.

\section{I75. silvestris, Reich.=syn. V. Reichenbachiana, Bor.}

Local. Abundant. Native. Septal and sylvestral.

In the hilly district, Caerphilly to Merthyr. J.S. and T.H.T. Recorded as V. sylvatica, hence possibly mixture of 175 and 176 . Near Lavernock Railway Station! I905. Intermediate types lead on to No. I 76 which occurs along with it. Cwmbach, Aberdare! I892. $\operatorname{Cog} !$ 1906. Dinas Powis ! Llanilid ! Llangan ! St. Fagans ! Cwrt-yr-Ala! and Michaelston-le-Pit! Many intermediates leading to No. I76. Dimlands! No doubt more widely spread, but as yet not recognised by local botanists.

176. Riviniana, Reich. Dog Violet. Pen y neidr.

Common. Abundant. Native. Septal and sylvestral. 
This is the common dog-violet of the district and doubtless the species which Mr. Storrie describes as common under the name of V. canina. Penarth! Lavernock! Sully! Dinas Powis! Llanharan! Llanilid ! Llangan! Garth Mountain ! St. Fagans ! Cwrt-yr-Ala ! Michaelston-le-Pit ! Monknash ! Marcross ! Nash !

The very dwarf forms growing in exposed situations have very small leaves, stunted growth, spurs often coloured more or less purple and slightly grooved. They approximate in habit, though not in flower, to $\mathrm{V}$. ericetorum, No. 178 .

178. ericetorum, Schrader.=syn. V. flavicornis, Sm.

Local. Abundant. Native. Littoral.

Mr. Motley has observed that it (V. flavicornis) is common in sand on the sea-coast. L.W.D.Mat. No records have been furnished by our correspondents of this species, but the Editor has noted it at Sully Island ! Swanbridge ! Porthcawl ! Kenfig, 1905 ! ! It is seen in perfection beyond Porthcawl Rest.

179. lactea, Sm.

A doubtful record, needing confirmation. "Mayal's Green, Gower, Glamorganshire." Phyt. I854. Caroline Catherine Lucas. p. 2 I6. Hensol!! June, I907.

180. stagnina, Kit.

Three records, needing confirmation. Caerphilly Common. J.S. Rhossili, Gower. S. Llanishen. H.E.

The next two species-Nos. I8I and r82-have been generally treated as an aggregate by local botanists, and the name of the first segregate-No. $18 \mathrm{I}$ - used, when in reality most of the specimens must have belonged to the second-No. I 82. Mr. Storrie and some others take in No. I 83 as well. New records are necessary for each of these species.

18 I. tricolor, Linn. Pansy. Llys y Drindod. Dauwynebog.

The only reliable record is that furnished by the Cardiff Museum, where there is a specimen labelled Pwllypant, I877. Storrie Collection.

I 82. arvensis, Murr. Field Pansy. Llys y Drindod.

Common. Abundant. Native. Agrestal.

Frequent. St. Fagans, Ely, etc. J.S. and T.H.T. Penarth, V. Barry. D. Common in Hirwain Area. W. Sully! G. Merthyr District. F. Llantwit Major! Pyle! Aberthaw! Rhoose!

\section{Curtisii, Forster.}

Local. Abundant. Native. Littoral.

T.B., J. of B. Supp. 1905, on authority of J. of B. 1902, p. 316 Port Talbot sand-hills. M.A.D. Porthcawl sand-hills. P. Porthcawl. N. First identified by Editor on Kenfig Burrows, 1897. It was noted on the sand-hills sixty years ago by Dillwyn, who, however, confused it with the next species. He says of No. I84, "Though generally an inhabitant of mountains, I have found it growing on Crymlyn Burrows." There are three distinct forms at least on the Burrows of the County-yellow, blue, and particoloured respectively.

These would repay experimental cultivation 
184. Lutea, Huds. Mountain Pansy.

There is an unsatisfactory record for this plant. Rare. Ystrad and near Llyn Fach. J.S. The author of the Flora of the Rhondda does not verify this locality, but quotes from the Flora of Cardiff. In the Cardiff Museum there are two specimens, a doubtful one labelled Ystrad, July, 1877, A. Langley, and a satisfactory one labelled Near Pontypridd Rocking Stone, Storrie Collection-a locality, it will be noted, not recorded by Storrie in the Flora of Cardiff. It is admitted in Topographical Botany, but no authority is given. The Editor has entirely failed to verify these localities, although the three have been searched, in the case of Llyn Fach repeatedly.

\section{I0. Polygaleæ.}

Polygala, Linn. $\mathbf{5 8 .}$

vulgaris, Linn. Common Milkwort. Amlaethai. Llaethlys.

An aggregate species made up of the following three-Nos, I85, 186 , and 187 as segregates.

Common. Abundant. Native. Ericetal.

Records for the segregates are very incomplete. All the forms examined critically by the Editor appear to belong to No. I86.

185. vulgaris, Linn.=syn. subspecies $P$. vulgaris, Syme.

T.B., J. of B. Supp. 1905. Authority of E. F. Linton for Glamorgan. On the banks of the Neath Canal, Penllergaer, Worms Head. Gutch in Phyt. I842. p. 107. The Cardiff Museum has a specimen labelled Caerphilly i877. Storrie Collection.

I 86. oxyptera, Reichb.

On the downs near Pennard Castle and frequent in other places. Flower \& Lees in Phyt. I843. p. 377. Llantwit Major ! Dinas Powis! Southerndown! Caswell Bay! Swanbridge! Near the Rest, Porthcawl. $N$.

187. serpyllacea, Weihe.

A poor record in the form of specimens in the Cardiff Museum, labelled Cefn On, Caerphilly, I877. A Langley, and Llanishen, A. Langley. Also Treorchy. $N$.

\section{Caryophyllex.}

\section{Dianthus, Linn. 60.}

193. Armeria, Linn. Deptford Pink. Pennigan y perfeydd.

Rare. Scarce. Alien? Pascual and viatical.

Banks about Briton Ferry, but not frequent. Flnwer \& Lees in Phyt. 1843. p. 378. Recent records wanting.

194. deltoides, Linn. Maiden Pink.

Rare. Scarce. Alien? Rupestral and glareal.

Very rare. Rhymney Railway bank, near Llanishen. J.S. Bank of Feeder, Cardiff. Mr. Chapman. Recent records wanting. 


\section{Saponaria, Linn. 6r.}

199. Vaccaria, Linn.

Local. Frequent. Alien, Viatical.

Occurs in considerable abundance every year. On and near ballast. All around Cardiff and Penarth Docks. J.S. Seen frequent on ballast at Penarth ! Barry Dock ! I890 and I 892.

200. officinalis, Linn. Common Soapwort. Sebonlys.

Local. Abundant. Native? Viatical.

Burrows about Marino, near Swansea; and plentifully between Cardiff and Llandaff. Dr. Turton, B,G. Plentiful on the Burrows, opposite to Singleton, and has been so since 1802. L.W.D.Mat. Frequent in the Taff, Rhymney, and Ely Valleys. J.S. Llan-ywrach, I830, J.E. Merthyr Mawr. $V$. Llandaff. $V$. and $I$. Near Gileston. B. and D. Ogmore River banks. Miss B. Taff Valley. M.A.D. and G.T. Cooper's Fields. P. Hirwain District, common. W. Merthyr District. F. Walnut Tree Junction! Dinas Powis ! Pentyrch!

\section{Silene, Linn. 62.}

20ı. Cucubalus, Wibel. Bladder Campion. Glydlys Corlrwth. Llysiau saith gwlwm synwyr.

Common. Abundant. Native. Septal and viatical, etc.

\section{b. puberula, Syme.}

Caswell Bay! Sully! Penarth !!

The variety is probably as widely distributed as the type, though not so abundant. Further records are desirable.

202. maritima, With. Sea Bladder Campion. Glydlys arfor.

Local. Abundant. Native, Littoral.

Rocks on the coast of Gower. Gutch in Phyt. I8-42. †. IO7. Frequent. Penarth to Southerndown. J.S. The Holms! T.H.T. Barry District! $D$. Southerndown, frequent. Miss $B$. Barry to Southerndown. B. Sully. G. Caswell Bay! Gower. G.T. Worms Head. S.

205. anglica, Linn. English Catchfly. Glydlys brutanaidd.

Rare. Scarce. Native. Agrestal and glareal.

Fields about Marino, near Swansea. B.G. Occasionally found in cornfields. L.W.D.Mat. Rare. Gabalva. J.S. Cornfield at Craig-yr-Eos, Southerndown, 1896. E.V. Field at Newton Nottage. Miss B. Barry Island. M.A.D. Penllergaer. G.T. Porthcawl!

\section{Lychnis, Linn. 64.}

213. alba, Mill. White Campion. G. gwyn flodeuog.

Common. Abundant. Native. Agrestal.

As this species was not included in the 2 nd edition of Topographical Botany, the records are given in full. Frequent. Near Cardiff, Penarth, etc. J.S. Frequent. Flora Rhondda. Also 
T.B., J. of B. Supp. 1905. E. F. Linlm. Fairwater. I. Barry! $B$. and $D$. Frequent through lower part of County. T.H.T. Southerndown. Miss $B$. Common in cultivated land and by hedgesides. P. Common. M.A.D. Aberdare, Hirwain. W. Sully ! G. Coedriglan. G.T. Merthyr District. F. St. Fagans ! Near Kenfig Pool ! rose-coloured, 1905. St. Donats !

214. dioica, Linn. Red Campion. Llys yr ychen.

Glamorgan name :-Llys y neidr.

Common. Abundant. Native. Septal and sylvestral.

21 5. Flos=cuculi, Linn. Ragged Robin. Blodeuyn y fran.

Common. Abundant. Native. Paludal.

21 8. Githago, Scop. Corn Cockle. Bulwg.

Local. Frequent. Colonist. Agrestal.

Frequent, Penarth, Sully, etc. J.S. Throughout lower part of County, but not frequent. T.H.T. E.ly, Gelligaer. E.V. Barry. $B$. and $D$. Sutton, Southerndown. Miss B. Aberdare, Hirwain. W. Sully. G. Merthyr District. F. Dinas Powis! Kenfig!

\section{Cerastium, Linn. 66.}

220. quarternellum, Fenzl. Upright Chickweed. Corwlyddyn syth. Rare. Scarce. Native. Glareal.

Rare. East Moors. J.S. Recent records desirable.

22 I. tetrandrum, Curtis. Dark Green Mouse-ear Chickweed. Glust llygoden. Cor-wlyddyn.

Local. Frequent. Native. Glareal.

Coast. Sully ! Barry ! etc. J.S. Sand-hills near Swansea. $J$. Woods, Junior. Leys ! B. Porthcawl, Southerndown. $N$. Sully! G. Sand-hills, Swansea. G.T. Llandough ! Swanbridge ! Aberthaw! Grangetown Marl Pits! Mumbles! Near Kenfig Pool ! where its variations are very puzzling.

\section{2. pumilum, Curtis.}

T.B., J. of B. Supp. 1905. On authority of E. F. Linton.

223. Semidecandrum, Linn. Little Mouse-ear Chickweed. Cor-wlyddyn. Local. Frequent. Native. Glareal.

Frequent. Penarth, Llandaff, etc. J.S. Barry. B. Hirwain. W. Sand-hills, Swansea. G.T. Llandough ! Grangetown Marl Pits ! Swanbridge ! Mumbles ! 1892. Near Kenfig Pool ! where its variations also are puzzling.

The three preceding species will repay further study, especially under cultivation. The Editor has not yet recognised No. 222, but the forms in Glamorgan appear to be more variable and therefore more puzzling than elsewhere. The recent records are very scanty and need amplification.

224. glomeratum, Thuill. Broad-leaved Mouse-ear Chickweed.

Common. Abundant. Native. Glareal. 
225. triviale, Link. Narrow-leaved Mouse-ear Chickweed.

Common. Abundant. Native. Pratal and viatical, etc.

These two common and well differentiated species, Nos. 224 and 225, are not well understood by our correspondents. Mr. Storrie confuses one of their many lorms with C. arvense, and is followed in this error by so many others, that the complete record is appended. It is almost certainly a case of wrong diagnosis. C. arvense is not admitted in Topographical Botany for Glamorgan, and is generally a very rare plant in Wales.

228. arvense, Linn.

Frequent. Penarth, Dinas Powis. J.S. and T.H.T. Frequent. Flora Rhondda. Frequent in fields and dry places, Barry. Common. Southerndown. Miss $B$. Sully. G. Hirwain ? W.

\section{Stellaria, Linn. 67.}

230. aquatica, Scop. Water Chickweed. Dyfrwlyddyn.

Rare. Frequent. Native. Paludal.

Frequent in watery places (near Swansea). Flower \& Lees in Phyt. I843. t. 378. - a record apparently ignored by Watson. Fairwater Lane, I898. M.A.D. St. Fagans, 1904. E.V. and I. St. Fagans! I905. Flemingston Moors! I 1905.

231. nemorum, Linn. Wood Chickweed.

Rare. Scarce. Native. Sylvestral.

" Discovered by Mr. Woods at Usgoed Hendry, and other places in the neighbourhood of Ystradgynlais." L.W.D.Mat. This may be a Breconshire locality. "A few specimens found in Bodringallt Woods in 1900." Flora Rhondda. Rare. Near Copper Works, Cardiff. J.S. A very unlikely locality. Storrie's plant was probably No. 230. The locality is now built over.

232. media, Cyr. Common Chickweed. Gwlydd y cywion.

Common. Abundant. Native. Agrestal, viatical, etc.

b. Boræana (Jord).

Near Kenfig Pool!! and Cwrt-y-fil, Penarth !

The species is very variable in the district and requires experimental study. The commonest form near Cardiff has a well developed corolla and three stamens.

234. Holostea, Linn. Greater Stitchwort. Tafod yr edn mwyaf.

Common. Abundant. Native. Septal and sylvestral.

\section{5. palustris, Retz.}

A form of S. graminea growing in marshes, apparently overlooked by botanists, and having non-ciliate bracts, has been generally mistaken for this species. All the records are probably errors. Common in wet places. J.S. and T.H.T. Hirwain. W. Coedriglan. G.T. Merthyr District. F. Mr. A. Bennett definitely identifies our marsh form as S. graminea.

236. graminea, Linn. Lesser Stitchwort. T. lleiaf.

Common. Abundant. Native. Septal, pascual, and paludal. 
237. uliginosa, Murr. Bog Stitchwort. T. y gors.

Common. Abundant. Native. Paludal and uliginal.

Arenaria, Linn. 68.

241. tenuifolia, Linn. Fine-leaved Sandwort. Tywod-wlydd meindwf. Records from Hirwain and Aberdare, $W$. and Southerndown. $M i$ ss $B$. No specimens seen.

242. trinervia, Linn. Three Nerved Sandwort. T. llyriad-ddail.

Common. Abundant. Native. Septal and sylvestral.

243. serpyllifolia, Linn. Thyme-leaved Sandwort. T. grywddail.

Common. Abundant. Native. Glareal, rupestral, etc.

No records are given for the varieties. The Editor has the following notes.

Type. Barry! Taffs Well ! Leys! Llandough ! St. Fagans !

c. leptoclados, Guss.

Barry ! Dinas Powis ! Llantwit Major ! Sully Island ! St. Fagans! This species would repay experimental investigation.

247. peploides, Linn. Sea Purslane. $T$, arfor.

Local. Frequent. Native. Littoral.

Common. Coast, Sully to Southerndown. J.S. and T.H.T. No longer common. Gileston! T. W. Proger. Fairly frequent on shore, Barry Island to Southerndown, $B$. Barry District, $D$. Newton Sands. Miss B. Worms Head. G.T. Aberthaw!

Sagina, Linn. 69.

The records furnished for this genus are unsatisfactory with the exception of those referring to No. 253.

249. maritima, Don. Sea Pearlwort. Corvlyddyn arfor.

Rare. Frequent. Native. Littoral.

About Salt House Point (near Swansea). Flower \& Lees in Phyt. 1843. p. 378. Porthcawl. Woods in Phyt. 1850. p. I060. T.B. Withers specimen. Sea coast, common. Sully, Barry, etc. J.S. and T.H.T. Possibly, in part at least, erroneous. After much searching along the coast it was at last found by the Editor on Barry Island!! along with abundant S, apetala, I905. Southerndown. Miss $B$.

250. apetala, Linn. Common Small-flowered Pearlwort. C. anafflodeuog.

Local. Abundant. Native. Glareal and viatical.

On walls and waste places, very common near Swansea. Flower \& Lees in Phyt. r 843. p. 378. Not common. Cooper's Fields, etc. J.S. Merthyr District. F. Very abundant at Penarth ! ! Barry Island ! Llandough ! and St. Fagans !

The variety b. prostrata (Gibs) occurs in Penarth on gravel walks, but does not seem to differ from the type except in habit, which is caused purely by its situation in places where it is apt to be rolled or trodden upon. 
251. ciliata, Fr. Fries' Small-flowered Pearlwort.

Rare. Scarce. Native. Glareal.

Cwrt-yr-Ala! Leys! Commenting on dried specimens submitted to him, Mr. Bennett remarks, "I should call this one of the Jordanic species between ciliata and apetala."

\section{Reuteri, Boiss.}

Dinas Powis ! Ystradowen ! ! Taffs IVell ! Garden Path at Penarth !! This form is scarcely worthy of specific distinction.

The last four species or forms require special attention at the hands of local botanists.

253. procumbens, Linn. Procumbent Pearlwort. C. gorweddawl. Common. Abundant. Native. Glareal, viatical, and pratal.

258. nodosa, Fenzl. Knotted Spurrey. Troellig clymog.

Local. Frequent. Native. Inundatal, etc.

Frequent on the sand-hills between Swansea and the Mumbles. Flower \& Lees in Phyt. I843. p. 378. Rare. Caerphilly Common, Taffs Well. J.S. Sand-hills, Porthcawl. P. Penllergaer. G.T. St. Brides, Southerndown ! Near Kenfig Pool ! Newton Nottage Burrows !

\section{Spergula, Linn. 70.}

259. arvensis, Linn. Corn Spurrey. Troellig yr yd.

Common. Abundant. Native. Agrestal.

\section{Buda, Adans. $7 \mathbf{I}$.}

260. rubra, Dum. Red-flowering Field Spurrey. Tywod-wlydd glas rudd.

Rare or Local ? Scarce or Frequent? Native. Glareal.

Plentiful in a stone quarry near Greenhill turnpike. Gutch in. Phyt. 1842. p. 107. Specimen in Cardiff Museum labelled Tennant's Canal side, Swansea, July, 1834. Conway Collection. About Docks, Penarth, etc. J.S. and T.H.T. Admitted in T.B. Occasionally in damp places near the sea, Barry. $B$. Southerndown. Miss B. Barry. M.A.D. Worms Head. G.T. Some of these records almost certainly belong to the next species, which is very abundant in the County.

26I. marina, Dum. Sea Sandwort. T. y morgreigiau.

Local. Abundant. Native. Littoral.

This is no doubt an aggregate species, and the various segregates have so far not been satisfactorily separated.

The following records are noteworthy:-

(a) for the aggregate species. Frequent. Coast, Penarth, Barry, etc. J.S. and T.H.T. Admitted to T.B. as aggregate by Watson, who, while giving two segregates, avows his inability to distinguish them clearly. Rhymney ! Taff ! Ely ! and Ddaw ! estuaries, abundant. Frequent on Salt Marshes, Barry. B. Southerndown. Miss B. Rhossili. M.A.D.

(b) for the segregates. 
Spergularia neglecta, Syme. One of the segregates. Cardift Museum specimen. Locality not given, but probably collected by Storrie in Glamorgan and named by A. Bennett. T.B., J. of B. Supplement. 1905. Authority of E. F. Linton.

Spergularia marginata, Syme. Another segregate. T.B., J. of B. Supp. I905. On authority of E. F. Linton. Barry Salt Marsh!! Ely Estuary!! Taff Estuary! Rhymney Railway!

The Editor has also collected a glandular form near the Leys, growing on dry sand and gravel, with seeds winged and unwinged.

Mr. A. Bennett cannot identify it with any other British form. The whole group of forms needs further detailed study.

\section{Polycarpon, Loefl. 72.}

264. tetraphyllum, Linn.

Sandy wastes between Pyle Inn and the sea. Dr. Turton. B.G. Rare. Near Canton Common. J.S. Possibly both are records of solitary introduced plants or errors. No specimen apparently preserved by Storrie.

\section{Portulaceæ.}

\section{Montia, Linn. 74 .}

267. fontana, Linn. Water Blinks. Dyfr-wlyddyn. D. y ffynon.

Common. Abundant. Native. Paludal, inundatal, and lacustral.

\section{Hypericineæ.}

\section{Hypericum, Linn. 77.}

271. Androsamum, Linn. Tutsan. Eurinlys bendiged. Gwaed y gwyr.

Local. Frequent. Native. Septal and sylvestral.

Frequent about Cardiff, Neath, Penrice, and throughout the County. B.G. In woods about Neath, Briton Ferry, Drymma, and Penrice. L.W.D.Mat. Frequent, St. Fagans, Dinas Powis! etc. J.S. Pendoylan. $I$. Coedriglan. $V$. and G.T. Barry. B. and D. Pencoed. Miss B. Maeslech, Llandaff. M.A.D. Castell Coch! $P$. Llanishen, $N$. Aberdare, Hirwain, Rhigos, $I V$. Merthyr District. F.

274. calycinum, Linn. Large-flowered St. John's Wort.

Rare. Frequent. Alien. Sylvestral, etc.

"In Nicholaston Wood, near Penrice Castle; and I believe it to be as much indigenous there as in any other part of Great Britain." L.W.D.Mat. Very rare. Near Pentyrch Forge. J.S. Cooper's Fields. Planted abundantly. J.S. (2) Side of disused railway, Dumbath Valley, Tondı. Miss B. Near Pentyrch. G.T. Hensol! 
275. perforatum, Linn. Dotted-leaved St. John's WVort. Cancloll. Common. Abundant. Native. Septal, etc.

(b) angustifolium, Gaud. A Cardiff Museum Specimen, without locality, probably collected by Storrie, is named b. angustifolium by $A . B$. The species must be treated as an aggregate until the segregates are better known.

276. dubium, Leers. Imperforate St. John's Wort. Godwyllon.

Local. Frequent. Native. Septal, etc.

Plentiful about Penrice. B.G. In the woods at Park and about Penrice. L.W.D.Mat. Frequent. St. Fagans, Llandaff, etc. J.S. and T.H.T. Frequent. Flora Rhondda. Common among the hills in Glamorgan. Woods in Phyt. 1850. p. I060. Lan-y-Wrach, August 5th, 1830. J.E. Barry. J.S. (2). Caerphilly, Pwllypant. V. WaInut Tree! Caerphilly! Castell Coch. H.E.

277. quadratum, Stokes. Square-stemmed St. John's Wort. Eurinllys pedrongl.

Common. Abundant. Native. Inundatal. etc.

278. humifusum, Linn. Trailing St. John's Wort. Euriullys man ymdaenawl.

Common. Abundant. Native. Pascual, etc.

281. pulchrum, Linn. Small Upright St. John's Wort. Eurinllys man syth.

Common. Abundant. Native. Ericetal, etc.

282. hirsutum, Linn. Hairy St. John's Wort.

Local. Frequent. Native. Septal and sylvestral.

"In thickets and hedges in the neighbourhood of Swansea." Flower \& Lees in Phyt. I843. p. 378. Cooper's Fields. Rare. J.S. Further end of Mr. Edwards' fishpond on the Llantrisant Road, July, 1830 . J.E. Sully ! Michaelston-le-Pit, Cogan ! V. St. Fagans. I. Barry District. D. Cwrt-yr-Ala! Dinas Powis! Cog Rises! Penarth! Llandough! Cogan Hall! Wenvoe! Swanbridge! This species deserves to be recorded with the highest degree of frequency in the Penarth area.

283. montanum, Linn. Mountain St. John's Wort. Eurinlly's mynyddawl.

Rare. Scarce. Native. Rupestral.

First found by the Editor in the Barry ! ! district in three separate habitats in 1892 . Specimens in University College Herbarium. Whitmore Bay. J.S. (2).

284. elodes, Linn. Marsh St. John's Wort. Eurinllys y gors.

Local. Abundant. Native. Uliginal.

Near Singleton and Port Tennant. Gutch in Phyt. I842. p. 107. Not common. Near Pontypridd, Caerphilly, Penylan, etc. J.S, and H.E. Tylacoch. Flora Rhondda. Garth. E.V. Pendoylan. I. Common near Caerphilly. About Aberdare. Glyncorwg, about Neath Vale, about Swansea, Sketty, Pennard, Ilston, Dunvant, Maes Marchog. T.H.T. Llanishen, Vale of Neath. D. Garth. Gower. M.A.D. Garth. P. Common near Hirwain. W. Pontypridd Common ! Hensol, very abundant and luxuriant ! 


\section{Malvaceæ.}

Althæa, Linn. 78.

285. officinalis, Linn. Marsh Mallow. Hoccysen y gors.

Rare. Scarce. Native. Paludal.

Cardiff Museum Specimen. Llwyswyrw Mill. (Glamorganshire added by A.B.). July, I837. Barry Island. Woods in Phyt. 1850. p. I060. Not Common. Hayes Wood, Sully. Barry Island. Plentiful. J.S. Flat Holm. J.S. (2). Very plentiful between Llanmorlais and Llanmadoc, Gower. 1905. V. Near St. Athan! but not frequent. B. Barry District. D. Sully. G.

Some of these records are probably erroneous, one of the other members of the order being mistaken for the true marsh mallow, The Editor has searched the Barry localities often and always in vain. Lavatera arborea occurred at Barry formerly and was either overlooked or mistaken for this plant. Two localities only are kuown to me, and in them the species is represented by one or two widely scattered plants only, viz., Aberthaw! and St. Athan! Oxwich and Llanmadoc. H. J. Riddelsdell in J. of B. Vol. 43, p. 92 .

286. hirsuta, Linn. Hispid Mallow.

Rare. Scarce. Alien. Viatical.

Rare. East Moors. J.S. Rubbish Heap at Hirwain. IV.

\section{Lavatera, Linn. 79.}

287. arborea, Linn. Tree Mallow. Mor-hoccysen. Malw yr hel.

Rare. Scarce. Native in places, often naturalized. Littoral and rupestral. Not paludal like No. 285 .

At Paviland Cave and in Loughor Marshes. Gutch in Phyt. I842. p. 107. Wild in two places in Gower. Wnods in Phyt. 1850. p. го6о. Second-hand information, probably referring to Gutch's two localities. Steep Holm ! Common. J.S. Steep Holm! V., I. and G.T. Flat Holm. T.H.T. The Leys. Creigiau. D. Dunraven Cliffs. Miss B. Gower Cliffs. G.T. A specimen was collected on Barry Island! about 1892 , on a part of the cliff destroyed when the graving dock was constructed. Very fine, in a semi-wild condition in a garden near the beach shelter at Penarth!

\section{Malva, Linn. 80.}

289. moschata, Linn. Musk Mallow. Hoccys mws.

Local. Frequent. Native. Septal, viatical, etc.

Common (near Swansea). Gutch in Phyt. I842. p. 107. Frequent. Barry, Porthkerry, Llandaff, Lystalybont. J.S. Not frequent. Flora Rhondda. Boverton. J.S. (2) Rubina. V. Barry District ! $B$. and $D$. Near Three Crosses, Dunvant. T.H.T. Southerndown. Miss B. Llanishen. N. Coedriglan. G. T. Not on North border near Hirwain and Aberdare. IV. Merthyr District. F. St.-y-Nyl! Aberthaw ! Llanbethery ! St. Athan ! 
290. sylvestris, Linn. Common Mallow. Hoccys cyffredin.

Common. Abundant. Native. Septal, viatical, etc.

201. rotundifolia, Linn. Dwarf Mallow. Hoccys bychan.

Local. Frequent. Native. viatical.

Near Singleton. Gutch in Phyt. 1842. p. ro7. Rare. Flemingston and St. Athan. J.S. Lavernock, Llantwit, Boverton, Barry Island ! Dinas Powis ! J.S. (2) Lavernock. I'. Steep Holm. I. Llantwit Major! Near Pontypridd, Rhossili, Pencoed. T.H.T. Worms Head. D. Southerndown. Miss B. and M.A.D. Porthcawl ! N. Swanbridge! Sully ! St. Donats !

Tilia, Linn. $8 \mathrm{I}$.

\section{Tiliaceæ.}

297. cordata, Mill. Small-leaved Lime. Pisgen?

Rare. Abundant? Native? Sylvestral.

Wood between Gower Inn and Penrice. Flower \& Lees. Phyt. 1843. p. 378. "Woods about Pont-Nedd-Fechan." According to Mr. Motley some fine old trees near Duffryn Mill, above Taibach. L.IV.D.Mat. In the Valley and Vale of Neath this species is common. T.H.T.

\section{Radiola, Roth. 82.}

\section{Lineæ.}

298. linoides, Roth. Allseed. Gorhadawg.

Local. Frequent. Native. Ericetal, inundatal, etc.

On the ascent of Cefn Bryn, in Gower. Woods in Phyt. I 850 . p. I058. Rare. East Moors and near St. Brides Major. J.S. Pendoylan, 1904. I. Near Merthyr, 1903. T.H.T. Pennard Burrows, Gower. July, 1850.A.B. Rocks at head of Swansea Bay. G.T. Hensol! 1905. Kenfig! I905.

\section{Linum, Linn. 83.}

299. catharticum, Linn. Purging Flax. Llin y tylwyth teg.

Common. Abundant. Native. Pascual. etc.

301. angustifolium, Huds. Narrow-leaved Flax. Llin culddail.

Local. Frequent. Native. Pascual and littoral.

Frequent about Swansea. B.G. Common about Swansea. L.W.D.Mat. Rare. Swanbridge, Colhugh, Barry, etc. J.S. East end of the field south of Penarth Church, June 8th, I832. J.E. Gileston. Cogan. $V$. Barry! $B$, and $D$. Southerndown. Miss B. Gileston. M.A.D. Roath. G.T. Celyn Farm, Llanishen. H.E. Penarth ! to Lavernock! I896 to i905. Abundant. Swanbridge ! Sully ! Abundant along the eastern section of the coast but easily overlooked.

302. usitatissimum, Linn. Common Flax. Llin cyffredin.

Local. Frequent. Alien. Viatical.

Never succeeds in maintaining itself from seed, hence the local records are not given. 


\section{Geraniacæ.}

\section{Geranium, Linn. 84 .}

303. sanguineum, Linn. Bloody Crane's Bill. Pig yr aran rhuddgoch. Local. Abundant. Native. Rupestral and littoral, etc.

Burrows about Penrice and Port Eynon, plentiful. Dr. Turton. (B.G.) Common about the cliffs of Gower. L.W.D.Mat. In great luxuriance near Pennard Castle. Gutch in Phyt. I842. p. 108. Very rare. Near Dunraven. J.S. Plentiful on sand-hills near Llanmadoc. Gower. E.V. and H.E. Profuse on headlands in Gower from Pennard westwards. Worms Head. Rhossili Down. Burry Island. Very Abundant. Flowers, rarely white, in Gower. T.H.T. (These white-flowered specimens deserve special study. Ed.) Worms Head. D. Cwm Mawr, Dunraven. Miss B. Gower. M.A.D. and G.T. Merthyr District, $F$.

304. striatum, Linn.

Recorded from Cooper's Fields, Fairwater, Michaelston-superEly, and Penarth; all doubtless planted or garden escapes.

306. phaum, Linn. Dusky Crane's Bill.

Rare. Scarce. Denizen? Septal, etc.

Very rare. Conper's Fields and Coedriglan. J.S. Cardiff Museum Specimen. Near Merthyr Mawr. John Storrie Collection. Glyn Neath near Pont-Nedd Fechan. J.S. (2) and Mr. John Ballinger. 1902. Vale of Neath. D. Merthyr Mawr. Miss B. Hirwain, as escape. IV. Cwrt-yr-Ala, T. W. Proger.

307. Sylvaticum, Linn.

Recorded, doubtless erroneously, by Storrie from Cwrt-yr-Ala, Coedriglan, and near Llanmaes.

308. pratense, Linn. Meadow Crane's Bill. Pig yr aran y weirglawdd.

Local. Frequent. Native. Pratal and septal.

Very frequent about Pont-Nedd-Fechan and Aberpergwm. B.G. Frequent on the hedge-banks between Aberpergwm and Pont-NeddFechan. L.W.D.Mat. Common in Meadows. Penrys Farm, MidRhondda, etc. Flora Rhondda. Fairoak Farm. H.E. Frequent. St. John's Churchyard, Blackweir, Sully, etc. J.S. Fairwater, 1904. I. Very fine and frequent near Merthyr, in Cwm Glais. Sides of River Nedd, Hepste and Perddyn, and in lower Glyn Neath. ascending to 800 feet in Vale of Neath. T.H.T. Woburn. D. Laleston. Miss B. Vale of Neath. IV. Dunraven. G.T. Vaynor, Merthyr, Llantrisant. $F$.

309. pyrenaicum, Burm. fil. Mountain Crane's Bill.

Rare. Scarce. Native? Viatical.

Between Swansea Ferry and the Race Course. Flower \& Lees in Phyt. 1843, p. 378. Found about South Cornelly, by Mr. Motley. L.W.D.Mat. Rare. Penarth Ferry and East Moors. J.S. Admitted to T.B. A record which requires confirmation, especially of the South Cornelly habitat. 
310. molle, Linn. Soft Crane's Bill. Troed y golomen.

Common. Abundant. Native. Glareal, etc.

311. pusillum, Linn. Small-flowered Crane's Bill. Pig yr aran manflodeuog.

Rare. Scarce. Native? Viatical, etc.

Frequent near New Cemetery, Penylan, etc. J.S. and T.H.T. Admitted to T.B. on authority of Miss A. M. Barnard, MS. Southerndown. M.A.D. Hirwain, Aberdare. W. Leys! 1905. Scarce. Sketty Burrows. H. J. Riddelsdell in J. of B. Vol. 43. p. 92.

312. rotundifolium, Linn. Round-leaved Crane's Bill.

Local. Frequent. Native? Viatical.

With G. lucidum on old walls about Newton, etc. Flower \& Lees in Phyt. I843. p. 378. Found by Mr. A. Henfry to be abundant about Swansea. L.W.D.Mat. Common. Cardiff, Penarth Ferry, East Moors. J.S. and T.H.T. Frequent. Flora Rhondda. Admitted to T.B. on authority of Barnard MS. Covering the wall at the foot of Leckwith Hill, April I7th, I83I. J.E. Common everywhere, Barry. B. Barry District. D. Southerndown. Miss B. and M.A.D. Common. $W$. Sully. G. Pennard. G.T. Llandongh Railway Embankment ! I899 to I905 along with other introduced plants. This is a very unsatisfactory record. Many, if not most of the habitats given are almost certainly erroneous. Specimens should be submitted for verification.

3 I3. dissectum, Linn. Jagged-leaved Crane's Bill. Pig yr aran llarpiog. Common. Abundant. Native. Septal, viatical, etc.

314. columbinum, Linn. Long-stalked Crane's Bill. Pig yr aran hirgoesog.

Local. Frequent. Native. Septal, agrestal, etc.

Between the Ferry and Port Tennant. Gutch in Phyt. I842. p. I07. Not common. Sully! Swanbridge! St. Athan, etc. J.S. Not common. Ynyshir, Penrhys Brook. Flora Rhondda. St. Nicholas, St. Fagans, Ewenny. $V$. Porthkerry. I. Plentiful about Barry B.! Barry District! D. and M.A.D. Southerndown. Miss $B$. St. Hilary. G.T. Occasionally through the Vale of Glamorgan. T.H.T. Aberthaw! Dinas Powis!

315. Iucidum, Linn. Shining Crane's Bill. Pig yr aran disclaer. Common. Abundant. Native. Septal and rupestral.

A humus plant like Adoxa.

3 6. Robertianum, Linn. Herb Robert. Pig yr aran troedrudd. Common. Abundant. Native. Viatical, septal, etc.

\section{Erodium, L'Herit. 85.}

317. cicutarium, L'Herit. Common Stork's Bill. Pig y Crëyr.

Local. Abundant. Native. Glareal and viatical.

Common. Llandaff, Penarth, Sully, Barry, etc. J.S. Barry. $I ., D$. and $B$. Southerndown. $B$. and Miss $B$. Throughout lower levels of County. T.H.T. Candleston. M.A.D. Porthcawl. P. 
Sully. G. Sand-hills, Swansea. G.T. This species is one of the most abundant and characteristic plants of our sand-hills, and is very variable. Concerning a very glandular form collected near Kenfig, submitted to him by the Editor, Mr. A. Bennett writes, "It must, I think, be named var. glandulosum Von d. Bosch."

319. maritimum, L'Herit. Sea Stork's Bill. Pig y Crëyr arfor. Local. Frequent. Native. Littoral and glareal.

On the sands about Oxwich, Port Eynon, and the Worms Head. L.W.D.Mat. Frequent. Steep Holn, Barry, Southerndown, and St. Donats. J.S. and H.E. Steep Holm, Southerndown. I. Southerndown. V., Miss B. and M.A.D. Penclawdd. T.H.T. Barry District ! D. Porthcawl ! St. Donats. G.T. Caswell Bay ! Aberthaw !

\section{Oxalis, Linn. 86.}

320. Acetosella, Linn. Wood Sorrel. Suran y coed gyffredin. Glamorgan name :-Bara caws y gwcw.

Common. Abundant. Native. Septal and sylvestral.

\section{b. sub = purpurascens, DC !} Castell Coch. $V$.

321. corniculata, Linn.

Recorded from Coedriglan. G.T. Southernrlown. J.S. Oxwich Bay. $D$.

\section{Impatiens, Linn. 87.}

323. Noli-tangere, Linn. Yellow Balsam. Ffromlys.

Rare. Scarce. Native? Sylvestral.

Llandough, Cowbridge. J.S. and G.T. Rare. Specimens found near Blaenrhondda. Flora Rhondda. The Editor collected some seedling specimens of an Impatiens at St. Mary Church Road. All the specimens left behind were afterwards smothered by an over. growth of nettles. 



\section{ADDITIONS AND CORRECTIONS TO SECTION I.- THALAMIFLORE.}

The records in Section I. credited to E. were the joint work of our Correspondents, Messrs. Evans and Fleming, of Merthyr Tydvil, and should have been credited to $E$. and $F$. In the present and subsequent sections $E$. and $F$. will be used to denote the conjoint records of these two botanists.

Since the publication of Section I., Mr. Riddelsclell has published his Flora of Glamorgan-a notable contribution to the taxonomic botany of the County. His work includes two species not reported by us, viz. :-

Ranunculus lutarius, Bour. Rhossili Down.

Viola calcarea, Greg. Ogmore Down.

Many new localities are given, especially in the western and northern parts of the County, and special attention is given to "critical" forms. In Section II. and the subsequent sections we shall indicate Mr. Riddelsdell's records, whenever they supplement or differ from our own, under the abbreviation Ridd.

Mr. Arthur Bennett has furnished us the following records for the very local Glam. species, Draba aizoides, Linn.:-

May, I87I. Dr. F. A. Lees. sp. Rocks at Pennard Castle.

April, I875. H. L. Jones. $s p$.

April, I882. T. B. Flower. $s p$.

April, I885. Dr. F. Parsons. sp.

May, I893. Mr. Nevinson. sp.

April I2th. I904. Rev. E. S. Marshall. sp. On limestone cliffs west of Pwlldu Head, Glam. Rev. A. Ley told Mr. Marshall that "it is plentiful on cliffs for three miles west of Pwlldu Head."

April, I877. T. B. Flower. Rocks at the Worms Head, Gower.

The first record was by Smith in Eng. Bot., I804. Found by John Lucas in 1795 near Worms Head, I6 miles west of Swansea; and in 1803 by Dr. W. Turton " on walls and rocks about Pennard Castle, eight miles west of Swansea."

TRANS, CARD. NAT, SOC,-SUPPLEMENT. 
Further additions are :-

\section{Ir. Silene noctiflora, Linn.}

St. Hilary. Mrs. Rice Nicholl, spu.!

\section{Impatiens fulva, Nuttall.}

Llandough, near Cowbridge. E., Rev. IV. F. Evans, and Ridd. This species is thoroughly naturalised, and abundant in many parts of the valley of the River Thaw, from Llansanwr to Gigman Bridge. It must have been the species recorded by Storrie as $I$. Noli-tangere. It alone grows in the woods near Llandough, and is abundant on both sides of the valley. This habitat for $I$. Noli-tangere should therefore be excluded.

\section{NOTES ON THE PREPARATION OF SECTION II.}

For the preparation of Section II. the Committee has had the assistance of most of its Correspondents of the previous year, and in addition :-

I. The Misses Lyons, Kilvrough, Parkmill, R.S.O., Glam. (L.)

2. H. M. Hallett, I3, Earl Place, Penarth. (H.)

Mr. A. Bennett has forwarded the records contained in-

I. Reports of the Bot. Record Club.

2. ," ,Watson Bot. Exch. Club.

3. ", "Bot. Exch. Club of the British Isles.

4. Botanical Gazette. Vols. I. and II. Ball's articles.

We have consulted in addition-

I. The New Swansea Guide. Swansea, I823, hereafter referred to under the abbreviation N.S.G.

2. The Proceedings of the Swansea Scientific Society.

The list of over 400 Swansea plants published by Mr. Jackett has not been utilised, as no localities are given for them.

The following additional abbreviations are used in Section II. :-

Yat. Hb., for the herbarium of the Cardiff Museum, destined to form the nucleus of the herbarium of the Nat. Mus. for Wales.

U.C. $H b$. for the herbarium of the University College, Cardiff. Vach. Hb. for the herbarium of Dr. C. T. Vachell. 


\section{I. Ilicineæ.}

llex, Linn. 88.

326. Aquifolium, Linn. Holly. Celynen.

Common. Abundant. Native. Septal and sylvestral.

Often planted.

\section{Celastrineæ.}

Euonymus, Linn. 89.

327. europæus, Linn. Spindle-tree. Piswydden. Y pren y crogodd diawl ei fam.

Local. Frequent. Native. Septal and sylvestral.

Frequent. Penylan; Leckwith ! St. Fagans ! Tongwynlais ! Pencoed, \&c. J.S. Penrice. N.S.G. Fairwater. M.A.D., I., and V. Llandough! V., J.E. and $H$. Cwrt-yr-Ala! $H$. Merthyr Mawr! Miss B. Bryntêg and Morlais Castle. E. and F. Park Mill, Gower. $L$. Frequent in Gower. Ridd. Sparingly distributed. D. Common. H.E. About Neath and Swansea. Flower \& Lees, Phyt. 1843. p. 378. Leckwith and Coedymwstwr. Nat. Hb. Penarth! Cogan! Dinas Powis ! Penlline! Sandhills, Nottage! Thinly distributed over the Vale of Glamorgan and Gower.

\section{Rhamneæ.}

\section{Rhamnus, Linn. 90.}

328. catharticus, Linn. Purging Buckthorn. Rhafnwydden.

Local. Frequent. Native. Sylvestral and septal.

Woods at Penrice; and on the Flat Holm. B.G. In Nicholaston, Cline and some other woods, L.W.D. Mat. Langland Bay to Oystermouth, Oxwich Bay, and Llanmadoc. Ridd. Barry! $D$. Near Southerndown. I. Lavernock. N. Vaynor. E. and $F$. St. Hilary. $I$. Banks of the Ewenny. $V$. Between Llandough and Penarth in 1836. J.E. Extinct probably on Flat Holm. T.H.T. Penarth ! abundant in many places. Sully ! St. Mary Church Road! Pop Hill, Dinas Powis!

329. Frangula, Linn. Berry-bearing Alder. Brauwydd.

Local. Frequent. Native. Septal and sylvestral.

Frequent. Whitchurch; Hensol; Pontypridd; \&c. J.S. Cline Wood. Phyt. 1842. Pontcanna. Miss Corbett. Hirwaun. W. Merthyr Tydfil district. E. and F. Hensol Castle, G.T. Cefn On; Caerphilly; and Roath Park Wild Garden. $V$. Near Garth Mine. J.S. (2) Between Llancaiach and Treharris. T.H.T. Llanishen. sp! U.C.Hb., Mr. Chapman. Crymlyn Bog; Neath; Aberdare to Penrhiwceiber; Peterston Moor; Llantrisant. Ridd. 


\section{Sapindaceæ.}

Acer, Linn. 91.

330. Pseudo=platanus, Linn. Sycamore, Masarnwydd mwyaf.

Common. Abundant. Alien. Sylvestral, \&c.

Seeds and establishes itself freely in many places.

33I. campestre, Linn. Common Maple. Masarnwydd lleiaf.

Local. Abundant. Native. Septal and sylvestral.

Common. Leckwith! Llandaff ! \&c. Frequently planted. J.S. Aberdare; Vale of Neath. $W$. Merthyr Tydfil district, common. E. and F. Penarth! Cwrt-yr-Ala! Wenvoe! Southerndown Road!

\section{Leguminosæ.}

Genista, Linn. 93.

333. anglica, Linn. Needle Furze. Cracheithinen. Câs gan arddwr. Eithin yr iâr. E. y gath.

Local. Frequent. Native. Ericetal.

Frequent. Lavernock ! Barry, Llantwit Major, \&c. J.S. Llanharry; Tondu; Stormy Down. Miss B. Ystradowen. M.A.D. Pendoylan. $I$. Aberdare. $W$. Merthyr district. E. and F. Near Bishopston and Kittle. L. Beaupré. G.T. Cowbridge; Pencoed; Penylan! V. Not common. D. Common. H.E. Clyne Common; Gowerton; Loughor; Rhigos; Aberdare; Mountain Ash; Quakers Yard. Ridd. Hensol! Llanishen !

335. tinctoria, Linn. Dyer's Green Weed. Melynog y waun. Melyngu. Llys melyn.

Local. Abundant. Native. Pascual, \&c.

Common. Penarth! Sully! Barry! \&c. J.S. Near Blaenrhondda Tunnel only. Flor. Rhondda. Llandwr and Forest Marsh ; near Penllergaer. Phyt. I842. Common at Barry. D. Common. H.E. Aberdare, Vale of Neath. W. Fairwater. I. Near Kittle, Gower, L. Penylan. V. Frequent in the Vale. T.H.T. Abundant near Radyr. J.E. Hirwaun Common ; Pyle to Margam ; Bridgend ; Monknash ; \&c. Ridd. Craig-yr-allt. Nat.Hb. Dinas Powis! Llandough !

Ulex, Linn. 94 .

336. europæus, Linn. Common Furze. Eithinen. Common. Abundant. Native. Ericetal, \&c.

337. Gallii, Planch. Planchon's Furze. Eithin ffreinig. Common. Abundant. Native, Ericetal, \&c. 


\section{Cytisus, Linn. 95 .}

339. scoparius, Link. Common Broom. Banhadlen.

Local. Abundant. Native. Ericetal, \&c.

Common. Llandaff! Llanishen! Lanedarn. J.S. Not common. Blaenrhondda; at one time common near Porth. Flor. Rhondda. Dumbath Valley; Miskin. Miss B. Barry. D. Fairwater. $I$. Aberdare; Vale of Neath. $W$. Cwrt-yr-Ala. $H$. Rhymney Railway; Merthyr Tydvil district. E. and F. Slopes of Neath Valley; On Llwyn; frequent in the hills, common in the Vale. T.H.T, Banks of Taff, near Radyr. J.E. Pont Wern, and Poppit Hill. Phyt. I 842. Frequent in Gower; Ystalyfera; Merthyr Mawr ; \&c. Ridd. Swansea! Taff's Well! Mostly planted.

\section{Ononis, Linn. 96.}

It is almost impossible to distinguish true from false records with respect to the two following species.

340. repens, Linn. Procumbent Rest-harrow. Hwp yr ychen. Câs gan arddwr. Tagaradr.

Local. Abundant. Native. Glareal, \&c.

a. inermis, Lange. Frequent. Penarth! Sully! Pwllypant, \&c. J.S. Frequent. Penrhys, Penrhiwfer, \&c. Flor. Rhondda. Port Tennant and Singleton. Phyt. 1842. Merthyr district. T.H.T., $E$. and $F$. Southerndown. Miss $B$. Frequent near Barry. $D$. Sully, Lavernock, Radyr. M.A.D. Aberdare, Vale of Neath. $W$. Common in Gower. L. Tongwynlais. V. Leckwith, J.E. Pontardulais; Gowerton; Swansea; Neath; Aberafan ; Porthcawl ; Bridgend; \&c. Ridd. Barry Island! Aberthaw! Llantwit Major! Cowbridge! Llanharry! Peterston! Taff's Well !

b. horrida, Lange. Briton Ferry; Aberafan; Porthcawl. Ridd. Barry, near the salt marsh ! Sully beach ! Leys !

There are forms at Cowbridge, Barry, Llanharry, and elsewhere, which scarcely come under either 340 or 341 . They are intermediate in type, having very short runners which grow obliquely upwards, so that the plants have neither the mat-like appearance of true repens, nor do they grow isolated like typical spinosa. These two species need further study; it is questionable whether the varieties founded upon the development of thorns breed true.

341. Spinosa, Linn. Upright Rest-harrow. Hwp yr ychen.

Local. Abundant. Native. Pascual, \&c.

Rare. Cogan! Penarth! \&c. Penarth! H. Langland Bay. L. Porthkerry Park. J.S. (2) Lavernock! Southerndown. V. River side near Llandaff bridge. J.E. Penllergaer; Swansea. Ridd. This plant is extremely abundant in many localities. On acres of heavy clay land on the Lias it is a very troublesome weed. Cross Co nmon! Leckwith Common! Leckwith to Caerau! Cogan! Penarth to Lavernock! Occasionally found without thorns.

342. reclinata, Linn.

On rocks at Port Eynon. Sept. I 8, I828. Woods. J. of $B$. 1907. p. 280 . 
Trigonella, Linn. 97.

343. purpurascens, Lam. Fenugreek. Corfeillionen wen.

Rare. Scarce. Native? Sub-littoral.

Banks of Ely River! near Llandough! apparently native. June, I 899. Not to be found in 1907. Ed. Rhossili. Ridd. On ballast at Cardiff. J.S. Ballast at Ynyshir. Flor. Rhondda.

\section{Medicago, Linn. 98.}

344. Sativa, Linn. Common Lucerne. Maglys rhuddlas.

Local. Abundant. Alien? Glareal, viatical, \&c.

Common on railway banks and waste ground. J.S. Common on Taff Vale Railway banks; Blaenrhondda; \&c. Flor. Rhondda. Common at Barry ! D. Radyr, M.A.D. Rhubina. H.E. Penarth! $H$. Llandaff. $I$. Llanishen, Grangetown, \&c. $V$. In some of these localities it maintains itself and spreads; it flourishes on the relatively sterile Triassic red marl.

No. 346 occurs occasionally on ballast, \&c. Port Eynon. Forster. With. Bot.

347. Iupulina, Linn. Black Medick. Maglys gwineuddu.

Common. Abundant. Native. Agrestal, viatical, \&c.

348. denticulata, Willd. Reticulated Medick.

Rare. Scarce. Native?

Rare. About Cardiff, Penarth, \&c. J.S. Almost certainly not native, but frequent formerly on ballast at Cardiff, Penarth, and Barry.

349. arabica, Huds. Spotted Medick.

Local. Frequent. Native? Viatical.

Frequent. About Cardiff, Penarth! Barry! \&c. J.S. Gower ; Port Talbot; Porthcawl; Taff's Well. Ridd. Barry. D. Hirwaun. IV. Porthcawl. $V$.

All the localities known to the Editor are suggestive of the introduction of this plant with ballast. The species produces seeds freely, and has persisted in several places around Penarth Dock, from I 89 I onwards.

350. minima, Desr. Little Bur Medick.

Rare. Scarce. Alien. Viatical.

Not common. About Cardiff, Penarth, Barry, \&c. J.S. Oxwich Bay. E. Lees. A record never confirmed, and therefore to be rejected. A typical ballast plant in the Cardiff area, never succeeding in holding its ground.

\section{Melilotus, Hall. 99.}

35 I. officinalis, Lam. Common Melilot. Meillionen y ceirw. Pysen y ceirw. Gwydro.

Local. Abundant, Native, or denizen, Viatical, \&c. 
Frequent. Penarth ! East Moors, \&c. J.S. Southerndown. Miss B. Taff's Well. M.A.D. and G.T. Cogan! M.A.D. Penarth! $H$. and $V$. Georgetown Tips, Merthyr Tydvil. E. and F. Fairwater. I. Langland Bay ! L. Ystradowen ! G.T. Penclawdd; Port Talbot; Aberdare. Ridd. Caswell Bay ! Lavernock ! Llandough ! Frequent in waste places about the docks at Cardiff ! Penarth ! Barry ! and Porthcawl ! and spreading on to hedgebanks, roadsides, and cultivated ground.

352. alba, Desr. Recorded from Llandaff, East Moors, Llanishen, Hirwaun, Penarth ! Cardiff ! Apparently never succeeds in establishing itself permanently anywhere.

353. arvensis, Wallr. Field Melilot.

Rare. Abundant. Denizen. Viatical.

Frequent on the ballast. J.S. Abundant near Railway Station, Barry Island ! from before 1905 onwards, on newly exposed red marl forming at first the sole vegetation, and therefore very suggestive of its probable value as green manure for such sterile soils. Taff's Well. M.A.D. The Deri, Rhiwbina. H.E. Hirwaun; Aberdare. $W$. Melingriffith. V. Gowerton; Swansea; S. Cornely. Ridd. Porthcawl. Cundall.

\section{Trifolium, Linn. I00.}

356. pratense, Linn. Red Clover. Meillionen goch. Marchfeillionen. Common. Abundant. Native. Pratal, \&c.

357. medium, Linn. Zigzag Clover. Meillionen wyrgam.

Local. Frequent. Native. Viatical, \&c.

Frequent. Llanishen, Sully, Penarth! \&c. J.S. Frequent. Tyntyla; Penrhys; Ffaldau Farm; Ferndale; \&c. Flor. Rhondda. Barry Island. M.A.D., J.S. (2), and $I$. St.-y-Nil ! I. and $V$. Llanishen. H.E. Aberdare, Vale of Neath. $W$. Common in Gower. L. Rhossili ; Gowerton; Mawdlam; Baglan. Ridd. Lower Penarth! St. Fagans! Taff's Well! Michaelstone-le-Pit! Llanharry! Llanfabon !

359. squamosum, Linn. Teasel-headed Trefoil.

Local. Abundant. Native. Littoral.

Not common. Rumney Moors; Pengam; East Moors ; \&c. J.S., Ridd., $V$. and Miss Shaw. Barry Dock. D. Barry Island. I. Southerndown. M.A.D. Crymlyn Burrows, 1832. J.E. Penarth ! Very abundant and truly native about the mouth of the Rhymney River; of doubtful status elsewhere.

363. arvense, Linn. Hare's-foot Trefoil. Meillionen gedeuog.

Local. Abundant. Native (? always). Glareal.

Southerndown. J.S. Swansea and Sketty Burrows. Flower \& Lees. Tennant's Canal side. Nat. Hb. Southerndown. Miss B. Barry. D. Taff's Well! M.A.D. Hirwaun. W. Porthcawl. $H$. Merthyr district. E. and F. Newton Nottage, $V$. Oxwich to Port Eynon; Ystalyfera; Aberafan. Ridd. 
365. striatum, Linn. Soft Knotted Trefoil. Meillionen rŷchog. Local. Abundant. Native. Glareal.

Rather common in the Rhondda (?). Flor. Rhondda. Gileston ! Barry ! M.A.D. The Leys ! 1. Southerndown. $V$. Oxwich to Port Eynon; Rhossili; Aberafan ; S. Cornely. Ridd. Ely Estuary! Llandough! Dinas Powis Common! Ogmore Down!

b. erectum, Leight. Cold Knap! Specimens a foot high were collected growing along with the usual form.

366. scabrum, Linn. Rough Rigid Trefoil.

Local. Abundant. Native. Glareal.

Sandhills along the coast. L.W.D.Mat. Rare. Near Rumney Bridge. J.S. Swansea and Sketty Burrows. Phyt. I842. Barry ! M.A.D. Porthkerry! Southerndown. V. Aberafan; Porthcawl ; Swanbridge. Ridd. Leys ! abundant. Caswell Bay ! Cold Knap ! and other spots near Barry!

367. glomeratum, Linn. Smooth Round-headed Trefoil.

Rare. Scarce? Native. Glareal.

Sandhills at Swansea and Sketty. L.W.D.Mat. Aberdare. Ridd. No specimens seen by the Editor. A record which must be regarded as somewhat doubtful.

368. suffocatum, Linn. Dense-flowered Trefoil. Meillionen fygiedig. Rare. Scarce? Native? Glareal.

Whitmore Bay, Barry. J.S. A doubtful record needing confirmation.

370. hybridum, Linn. Alsike Clover.

Common. Abundant. Colonist or Alien. Agrestal, \&c.

371. repens, Linn. White Clover. Meillionen wen y waun. M. olwen. Common. Abundant. Native. Pascual, \&c.

The chief source of the honey produced in this county.

372. fragiferum, Linn. Strawberry-headed Trefoil. Meillionen fefusaidd.

Local. Frequent. Native. Pascual, \&c.

East Moors. J.S. Near Singleton; Banks of Neath Canal. Phyt. 1842. Pengam Moors! Nat. Hb. Merthyr district. E. and F. Six Wells, Llantwit Major. J.S. (2). Rhossili ; Llanmorlais to Llanrhidian; Aberafan; Kenfig Pool. Ridd. Ely Estuary! Heoly-mynydd, Southerndown! Ogmore Castle !

373. resupinatum, Linn. Reversed-flowered Trefoil.

Local. Scarce. Alien. Viatical.

About Cardiff Docks. J.S. Barry. D. Cathays Park! Llandaff; Ely. M.A.D. Cathays Park! V. Porthcawl and Swansea. T.H.T. Leys! Penarth Dock! and other places in the Ely Estuary. Probably seeding nowhere, hence a typical alien maintaining its position by constant introduction.

375. procumbens, Linn. Hop Trefoil. Meillionen hopysaidd.

Common. Abundant, Native. Pascual, \&c. 
376. dubium, Sibth. Lesser Yellow Trefoil. Meillionen felen fechan. Common. Abundant. Native. Pascual, \&c.

377. filiforme, Linn. Least Yellow Trefoil. Meillionen felen eiddil. Local. Abundant. Native. Pascual, \&c.

Penarth ! Llandaff, \&c. J.S. Pendoylan. I. Common at Aberdare. $W$. Penarth. $H$. Common in Gower. L. Margam and Baglan; Cowbridge; Wenvoe and Porthkerry; Blaennant, at I,ooo feet; Caerphilly. Ridd. Cogan! Lavernock! Dinas Powis Common! Pyle to Kenfig!

\section{Anthyllis, Linn. ror.}

378. Vulneraria, Linn. Ladies' Fingers. Plucen felen. Meillionen felen.

Local. Abundant. Native. Rupestral and pascual.

Penarth! Sully; Pwllypant. J.S. Bodringallt; Tylacoch;

Blaen-y-cwm. Flor. Rhondda. Caswell Bay. Nat. Hb. Singleton, Kilvey Hill. Phyt. I842. Southerndown. Miss B. Swanbridge; M.A.D. Llanishen. H.E. Aberdare. $W$. Merthyr district. E. and $F$. Pendoylan. $I$. Frequent on Gower coast. L. Barry Island ! J.S. (2). Frequent on the coast. $V$. Plentiful on coast and following the railways inland; Dunvant and Tondu. T.H.T. Ystradowen; Craig Llanishen. Ridd. Marcross ! Cold Knap ! Nash ! Llanharry! Sully! \&c.

b. coccinea, Linn. Swansea sandhills, L.W.D.Mat. Porthcawl. U.C. Hb. Porthcawl to Sker! Marshall and Schoolbred, J. of B. 1902. Occasionally on Gower coast. L. Mewslade Bay; Langland Bay. Ridd.

c. ovata, Bab. Rhossili. Ridd.

\section{Lotus, Linn. 102.}

379. corniculatus, Linn. Common Birl's-foot Trefoil. Pysen y ceirw grythog.

Common. Abundant. Native. Pascual, \&c.

b. crassifolius, Pers. Recorded by Riddelsdell in his $F$. of $G$. from Gower, Margam, and the Leys.

c. villosus, Ser. Gower coast; Aberafan Burrows; Aberdare. Ridd. Porthcawl !

380. tenuis, Waldst. \& Kit. Slender Bird's-foot Trefoil.

Local or Rare. Scarce. Native. Pascual, \&c.

Cardiff Marshes. Ridd. Stonylands Farm, near Penarth! Barry Island, near the Pond. Cogan Hall, near Penarth, in 1907. Ed. Forms intermediate between 379 and 380 were collected near St. Mary Hill. Not native, 1 fear, in all the stations; possibly introduced in all.

381. uliginosus, Schkuhr. Marsh Bird's-foot Trefoil.

Common, Abundant, Native. Uliginal, pratal, \&c, 
Astragalus, Linn. 103.

386. glycyphyllos, Linn. Sweet Milk-vetch.

Rare. Scarce. Native. Sylvestral or septal.

Barry! scarce. D., V., M.A.D., T.H.T. and J.S. (2). First noticed by $E d$. about I 899. Much increased by 1905. Still increasing, 1907. Last seen in Penarth locality about 1870.

\section{Ornithopus, Linn. I05.}

389. perpusillus, Linn. Least Bird's-foot. Troed yr aderyn cyffredin. Rare. Scarce. Native. Glareal.

Sully, Barry. J.S. Porthcawl. Mr.Chapman. Near Swansea; Baglan; Aberafan. Ridd in F. of G. Newton Sandhills. Mis. B. Top of hill at Notthills, near Penmaen, Gower. L. Porthcawl and Newton Nottage. T.H.T.

\section{Hippocrepis, Linn. 106.}

391. comosa, Linn. Horse-shoe Vetch.

Local. Abundant. Native. Rupestral and pascual.

Penard Castle! 1892. Old Castle Down! 1899. Ewenny Down! 1907. Very abundant. Ed. Limestone cliffs near Penard. Ridd.

\section{Onobrychis, Linn. 107.}

392. viciafolia, Scop. Sainfoin. Codawg.

I.ocal. Abundant. Native? Pascual.

St. Fagans, Llantwit Major, Boverton. J.S. Southerndown. Miss B. Abundant at Rhoose! probably planted. D. and $V$. Barry ! I. Penarth Railway Embankment ! $H$. Three Crosses. T.H.T. Sully! Nash! I.lantwit Major! Often cultivated in Glam. It succeeds so well on the Triassic marls and conglomerates, that it spreads and establishes itself on the railway banks, as at Sully. It seldom succeeds on the Lias, generally dying out in the second year, but near Rhoose Railway Station it flourishes even on this formation. I have seen the sainfoin on a field at Penarth on the boundary between the Rhaetic and Triassic marls, completely disappear from the Rhaetic end, while it continued to flourish on the Triassic portion.

Vicia, Linn. 108.

393. hirsuta, Gray. Hairy Tare. Corbysen flewog.

Common. Abundant. Native. Septal, \&c.

394. gemella, Crantz. Four-seeded Slender Tare. Corbysen lefn bedair ronynog.

Local. Frequent. Native. Septal, \&c.

Frequent. Cardiff; Penarth; St. Fagans; \&c. J.S. Near Blaen-y-cwm Tunnel. Flor. Rhondda. Near Swansea. Phyt. 1843. Fairwater. $I$. St. Fagans. $V$. Newton; Llanishen; Rudry. Ridd, Barry Ballast, I891. U.C. Hb. 
395. gracilis, Loisel. Many-seeded Slender Tare.

Tondû and Maesteg. Record needing confirmation.

396. Cracca; Linn. Tufted Vetch. Tagwyg bysen.

Common. Abundant. Native. Septal, \&c.

397. Orobus, DC. Wood Bitter Vetch.

Local. Frequent. Native. Pascual, \&c.

Found by D. Llewelyn in the grounds of Penllergaer, by Moggridge at Coedtrenig and by Dr. Hooker at Scwd Eynon Gam. L.W.D.Mat. Aberdare; Vale of Neath. W. Merthyr district. E. and F. Glyn Neath to Hirwaun; Cwm Selsig, Rhondda Valley. Ridd.

398. sylvatica, Linn. Wood Vetch. Ffugbysen y wîg.

I.ocal. Frequent. Native. Sylvestral and septal.

Caerau, St. Fagans, near Cadoxton, \&c. J.S. Penrhys Brook, Bodringallt Woods. Flor. Rhondda. St. Fagans. M.A.D., I. and V. Caerau. M.A.D. Dinas Powis. H.F. St. Andrews. H. Radyr Quarry. $V$. Plymouth Wood, near Ely. J.S. (2). Penlline! Rev. W. F. Evans. Bridgend to Penyfai ; Llanharry. Ridd.

399. sepium, Linn. Bush Vetch. Ffugbysen y cloddiau.

Common. Abundant. Native. Septal, etc.

flove albo. In meadows about Ynyspenllwch Bridge, discovered by Mr. Edward Hawkins. L.W.D.Mat.

403. Sativa, Linn. Common Cultivated Vetch. Ffugbysen maethawl. Common. Abundant. Denizen. Viatical, \&c.

404. angustifolia, Linn. Common Wild Vetch. Pysen y wîg.

Local. Abundant. Native. Glareal, \&c.

Frequent. Rumney, Pengam, Penarth! St. Fagans! J.S. Common at Barry. D. Llandaff to Radyr. M.A.D. Aberdare, Vale of Neath. W. Merthyr district. E. and F. Cross Common ! Grangetown! Ely! and many other places of which no record was made. Gowerton; Loughor; Ystalyfera; Neath. Ridd.

b. Bobartii, Koch. Llanishen; Aberdare. Ridd.

405. lathyroides, Linn. Spring Vetch.

Frequent. Grangetown, Penarth, Roath, \&c. J.S. Frequent. Bodringallt, Penrhys Brook, \&c. Flor. Rhondda. Porthcawl. Cundall, J. of B. I902. Southerndown. Miss B. Barry. M.A.D. Penarth. $H$. Porthcawl. I. Gower. L.

The Editor has searched for this plant in vain for many years. Until specimens with ripe seeds are submitted for verification, the record must be regarded as doubtful.

406. bithynica, Linn. Bithynian Vetch.

Admitted to T.B. and English Botany, Edition III. on the strength of a British Museum sp. Wood near Cardiff, Needs confirmation, 


\section{Lathyrus, Linn. 109.}

407. Aphaca, Linn. Yellow Vetchling.

Local. Scarce. Alien. Agrestal, \&c.

Frequent. E. Moors ; Grangetown; Penarth! Cowbridge ; Llantrissant. J.S. Near L.eckwith Road Railway Bridge. Nat. Hb. Porthcawl. Cundall. J. of B. 1902. Cathays Park. T.H.T. Between Lavernock and Sully. R. Drane. Llanmaes. spn.! PoleEvans. Occasionally in cultivated land about Penarth.

408. Nissolia, Linn. Grass-leaved Vetch.

Rare. Scarce. Native. Pascual, \&c.

Lavernock, Swanbridge, Barry, \&c. J.S. Lavernock Cliffs. $N a t . H b$. Penarth. $H$. Rhoose. $V$. In S.E. corner of the field in front of Llandough parsonage. J.E. Extinct possibly at Lavernock. Searched for recently in vain. Have seen specimens from this locality. $E d$.

411. pratensis. Linn. Meadow Vetchling. Ydbysen y waun.

Common. Abundant. Native. Pratal, septal, \&c.

414. sylvestris, Linn. Narrow-leaved Everlasting Pea. Ydbysen barhaus gulddail.

Local. Frequent. Native. Sub-littoral, septal, \&c.

Caswell Bay! B.G. Caswell Bay, Oxwich Wood, and other places in Gower. L.W.D.Mat. Frequent. Sully; Penarth! St. Fagans; \&c. J.S. Near Caerau. Nat. Hb. Oystermouth Castle. Phyt. I842. Between Cowbridge and Bridgend. Rev. W. F. Evans. Merthyr Mawr. Cundall, J. of B. 1902. Penarth to Lavernock. M.A.D., H. and V. Barry. D. and T.H.T. St. Fagans. I. and G.T. Aberdare? $W$. Abundant on Oxwich Point and near Langland Bay! L. Bridgend. G.T. St. Fagans Wood. V. Colhugh; Llantwit Major; St. Donats; Pwlldû, Gower; Loughor ; various places in Gower, all near the sea. T.H.T. Plymouth Wood. J.S. (2). Porthkerry; Wenvoe. Ridd.

415. palustris, Linn. Marsh Vetchling.

Rare. Scarce? Native. Paludal.

Llanrhidian. $J$. of $B$. I89I. p. $25 \mathrm{I}$.

4r7. montanus, Bernh. Tuberous Bitter Vetch. Pysen y coed gnapwreiddiawg.

Local. Frequent. Native. Rupestral, sylvestral, \&c.

Common. (?) Penylan, Wedal, Llanishen, Pwllypant, \&c. J.S. Blaenrhondda. Flor. Rhondda. Penllergaer and Clyne Wood. Phyt. 1842. Wedal, near Cardiff, Nat. Hb. Rhubina. M.A.D. and $V$. Merthyr district. $E$, and $F$. Pwllypant, \&c. $V$. Common (?) in Vale and frequent in hill-side hedges. T.H.T. Rhossili; Loughor ; Craig-y-Llyn; Aberpergwm, \&c. Ridd. Ystrad Mynach ! U.C. Hb. Pyle to Kenfig! Often observed, but as the record shows, not a common plant in S.E. Glam.

b. tenuifolius, Reich. fil. Ystrad Rhondda. N. Aberdare, frequent. Ridd. 


\section{Rosaceæ.}

\section{Prunus, Linn. I 10.}

419. spinosa, Linn. Sloe. Draenen ddû.

Common. Abundant. Native. Septal, \&c.

Mr. T. H. Thomas reports a fasciated, dwarf prostrate form from Port Eynon, Worms Head, and Rhossili, Gower.

b. macrocarpa, Wallr. Apparently this variety is widely distributed all over the Vale, and has been recorded under 420 . The flowers in particular differ much in the size of the corolla. There may be more than two forms of 419 .

420. insititia, Huds. Bullace. Eirenen bulas.

Frequent. Dinas Powis, Duffryn Golwg, Pencoed, \&c. J.S. Barry. D. Lavernock. $H$. Barry Island; Six Wells. J.S. (2). Llangenydd ; Pantyffynon; Rhigos; Baglan; Bridgend; Marcross; Llandow; St. Donats; Cowbridge; Wenvoe; Cadoxton. Ridd. An unsatisfactory record, probably based chiefly, if not entirely, on the variety macrocarpa, Wally. of No. 419. The Editor has examined thousands of specimens of $P$. spinosa, from most of the above localities, varying greatly in flower and fruit, but has never seen the Bullace in Glamorgan, nor found anyone who could furnish him with a specimen of the fruit. Several of our correspondents know the true Bullace well.

422. Avium, Linn. Gean. Ceiriosen ddû. Sirianen ddû.

Local. Frequent. Native? Sylvestral.

Frequent. Llandaff, Penarth, Cwm George, Coedriglan, \&c. J.S. Barry. D. Merthyr district. E. and F. Common in Crowley Woods, Gower. L. Pwllypant. V. Near Aberdare. Ridd. Cowbridge to Bridgend! Llandough! Llanilid! This tree grows in so many places in the Vale of Glamorgan, that one may see scores of them in a twenty-mile ride in spring, when the trees are in blossom. Their distribution makes it all but certain that they have seldom been planted. There seems no valid ground therefore for excluding this species from the list of true natives. $E d$.

423. Cerasus, Linn. Dwarf Cherry. Ceiriosen. Sirianen.

Rare. Scarce. Native? Septal.

Taff's Well. J.S. Llangenydd; Penllergaer; Wenvoe. Ridd. F. of $G$.

The following records probably belong to 422 , although sent in under 423. Knip Wood, near Southerndown. Miss B. Pendoylan. I. Common. H.E. Coedriglan. G.T. This species does not develop into a tree. Leighton says it reaches 3 to 6 feet in height, Bromfield 6 to 8 feet. The status of this species in Glamorgan is at least as doubtful as that of the preceding one. 
424. Padus, Linn. Bird Cherry.

Local. Frequent. Native. Septal, \&c.

Merthyr Tydfil! and Pontneddfechan! B.G. Hirwaun!

L.W.D.Mat. Frequent. Barry, St. Hilary, Gigman Bridge ! \&c. J.S. Glyn Cymmer. Flor. Rhondda. Castell-upon-Alun. Miss B. Barry. $H$. Pendoylan. $I$. Vale of Neath. $W$. Merthyr district. $V ., E$. and $F$. Pontneddfechan. G.T. Penllergaer; Loughor;

Aberdare. Ridd. Flemingstone! Scarce.

\section{Spiræa, Linn. III.}

426. Ulmaria, Linn. Meadow Sweet. Erwaint. Chwŷs Arthur.

Meddlys. Llysiau y forwyn.

Common, Abundant. Native. Paludal, pratal, \&c.

var. denudata, Boenn. Peterston, I907, with many intermediate forms connecting it with the type. Ed. Llanrhidian; Port Eynon; Gıyn Neath; Port Talbot; Bridgend; Aberdare; Penrhiwceiber; Taff's Well; Caerphilly; Llanishen. Ridd. F. of $G$.

427. Filipendula, Linn. Dropwort. Crogedyf.

Rare. Scarce. Native. Pascual.

Penarth, Heol-y-mynydd, Ham. J.S. Perhaps extinct in each of these habitats. Confirmation desirable. Tom Harman's meadow, I83o. J.E. A locality near Llandaff.

\section{Rubus, Linn. II2.}

Owing to the appointment of our correspondent Mr. Illtyd Buller Pole-Evans to the position of Plant Pathologist to the Transvaal Agricultural Department, he was unable to complete his study of the critical genera Rubus and Rosa. Under these circumstances the record in each of these genera must for the present be confined to the non-critical and aggregate species. A fuller treatment will appear subsequently in an appendix.

428. idæus, Linn. Raspberry. Afanen. Mafonwyld. Mafonllu.

Local. Abundant. Native. Sylvestral, \&c.

Frequeñt. Llantrithyd; Heath; Gigman; \&c. J.S. Ynyshir; Bodringallt; Mid Rhondda; Blaenrhondda. Flor. Rhondda. Candlestone. Miss B. Pontcanna; Castell Coch. M.A.D. Common about Aberdare. $W$. Cwrt-yr-Ala. $H$. Pendoylan. $I$. and $V$. Frequent near Park Mill, Gower. L. Penllergaer; Coedriglan. G.T. Frequent over County; profuse in some parts of the hills along the $\mathrm{N}$. border from the Vale of Neath to the River Tawe. T.H.T. Llancaiach. V. Perddyn Gorge; Melincourt Glen; Resolven. Ridd. Above Llyn Fach! about 1,700 feet high. 1905.

fruticosus, Linn. Blackberry. Mwyaren ddû.

Common. Abundant. Native. Septal, sylvestral, \&c.

This aggregate species has been so split up into segregates, that in the British Isles alone more than roo species are now recognised. About 60 of these have been observed to occur in Glamorgan. 
525. casius, Linn. Dewberry. Mwyaren Mair.

Local. Abundant. Native. Glareal, \&c.

Frequent. Barry Island ! St. Hilary ! Llantwit ! Llanmaes. J.S. Slon, Southerndown. Miss B. Barry ! D. Merthyr Mawr ! M.A.D. Penarth! $H$. Pendoylan and Fairwater. $I$. Common in Gower. $L$. All along the coast with little interval, fruiting better towards the W. T.H.T. Dunraven ! V. Ystalyfera; Resolven; Melincourt Glen; hills behind Port Talbot; Ewenny; Monknash; Llandaff. Ridd. St. Donats ! Candlestone ! Newton Nottage ! \&c. Very frequent on the sandhills, representing, with the bracken and Salix repens, the last stage in succession, just as the Psamma represents the first.

526. Saxatilis, Linn. Stone Bramble.

Rare. Scarce. Native. Rupestral.

About Pontneddfechan! L.W.D.Mat. Morlais Castle; Llyn Fach ! Rhigos. W. Merthyr district ! E. and F. Cwm Glais, near Merthyr. T.H.T. Craig-y-Llyn ! Ridd. J. of B. 1906. Perddyn Gorge. Ridd. in F. of $G$.

\section{Geum, Linn. I4.}

529. urbanum, Linn. Wood Avens. Mabgoll. Bendigeidlys. Llys f'anwylyd. Llys bened.

Common. Abundant. Native. Septal, \&c.

530. rivale, Linn. Water Avens. Mabgoll glan y dwr.

Local. Frequent. Native. Paludal, rupestral, \&c.

Scwd Einon Gam. About Pontneddfechan ! B.G. About Ynyspenllwch Bridge, Ynysygerwm. L.W.D.Mat. Cwm George ! Pontypridd, \&c. J.S. Blaen-y-cwm; Penrhys Brook. Flor. Rhondda. Vale of Neath. D. and W. Talygarn. M.A.D. Near Coedriglan. G.T. and H.E. Aberdare; Rhigos. W. Merthyr district. E. and F. Aberdare; Rhossili; Llanmadoc. T.H.T. Ystradowen. $V$. Banks of Taff near Llandaff. J.E. Near Ruperra ; Llanishen. Ridd. Cliffs above Llyn Fawr !

$\times$ urbanum (intermedium, Ehrh.) Near Coedriglan. G.T. and H.E. Neath Valley. H.E.

\section{Fragaria, Linn. 115 .}

531. vesca, Linn. Wild Strawberry. Mefusen y goedwig. Sifyen. Common. Abundant. Native. Sylvestral, \&c.

\section{Potentilla, Linn. I 6.}

535. Fragariastrum, Ehrh. Barren Strawberry. Coeg fefusen.

Common. Abundant. Native. Septal and sylvestral.

536. verna, Linn. Spring Cinquefoil.

Rare. Scarce? Native. Rupestral and glareal.

Above the cliffs between Port Eynon and Worms Head, B.G.

Caswell Bay. Ridd. F. of G. Cliffs near Worms Head. G.T. 
538. silvestris, Neck. Common Tormentil. Tresgl y moch. Melyn y twynau.

Common. Abundant. Native. Ericetal, \&c.

This species varies much, ranging from the small plants of the uplands to large ones approximating to No. 539. Can probably be resolved in to several segregates. Experimental cultures are necessary for this purpose.

539. procumbens, Sibth. Creeping Tormentil. Tresgl ymlusgaidd.

Local? Abundant. Native. Septal, etc.

This plant is, I fear, generally classed by our correspondents with the much commoner $P$. reptans. The records are therefore fewer than they should be. Coedriglan. G.T. Breaches, Penarth!! Sully Island ! Sully ! Southerndown ! Llandough ! Taff's Well! Pontypridd ! Llanfabon ! Eglwysilan ! Llanharry ! Peterston ! Sometimes difficult to distinguish from its hybrids with 540 and 538 . $\times$ reptans (mixta, Nolte). Welsh St. Donats, Caerphilly. Ridd. Penarth! Peterston-super-Ely!

$\times$ silvestris. A large number of well differentiated types come under this head, some of them producing abundant seed, but none rooting at the nodes. Welsh St. Donats; Ystradowen. Ridd. Llanharry ! Llanfabon! Eglwysilan!

540. reptans, Linn. Creeping Cinquefoil. Pumnalen gyffredin ymlusgaidd.

Common. Abundant. Native, Septal, \&c.

$\times$ silvestris. Caerphilly; Craig Llanishen. Ridd. Pendoylan ! Eglwysilan!

Nos. 538, 539, and 540 and their hybrids need thorough investigation. It is clear that no botanist at present understands them. No. 538 is certainly an aggregate, with apparently three or four segregates in Glam.

541.- Anserina, Linn. Silver-weed. Tinllwyd. Gwyn y merched. Common. Abundant. Native. Viatical, \&c.

545. palustris, Scop. Marsh Cinquefoil. Llygad-ysgytarnog.

Local. Frequent. Native. Uliginal.

Frequent. Llanishen; Barry; Cowbridge. J.S. Bryn Mill. N.S.G. Crymlyn Bog. Lees. N.B.G. Singleton Marsh; Penllergaer. Phyt. 1842. Ewenny. Miss B. Llanishen. D. Pendoylan! M.A.D., I. and $V$. Hirwaun. $W$. Penllergaer. G.T. Near Aberdare. T.H.T. Ystradowen ! V. Fairwood Common; Mynydd Garngoch; Llynfach; Peterston; Welsh St. Donats! Ridd.

\section{Alchemilla, Linn. II7.}

547. arvensis, Scop. Parsley Piert. Troed y dryw.

Common. Abundant. Native. Glareal.

548. vulgaris, Linn. Common Lady's Mantle. Mantell Fair. Simmwr y cor. Palf y llew.

Local. Frequent. Native. Pratal, \&c. 
Sophia Gardens, Cooper's Fields, Llandaff, \&c. J.S. Bodringallt, Porth, \&c. Flor. Rhondda. Common at Barry. D. Walnut Tree; Radyr. \&c. M.A.D. Common at Aberdare. IW. Civrt-yrAla ! Penarth ! $J$. St. Fagans. I. Radyr. J.E. Swansea ; Ystradowen; Rhyn ney. Ridd. Ystrad Mynach! Welsh St. Donats ! Little Garth ! Cowbridge ! Llantrisant! \&c. The three segregates have been recognised in the County. Ridd, $F$. of $G$. Attention should be paid to this aggregate. Specinens may be sent to the Secretaries for verification.

\section{Agrimonia, Linn. 118.}

551. Eupatoria. Linn. Common Agrimony. Tryw. Ciwlyn y mêl. Llysiau'r fuddai.

Local. Abundant. Native. Pascual.

Cogan, Leckwith, Lavernock, \&c. J.S. Absent from Rhondda Valleys. Flor. Rhondda. Extremely common on the calcareous measures in the southern part of the county. Records for the northern parts are scanty, and are probably confined to calcareous areas or railway ballast. Very rare in the neighbourhood of Hirwaun, but occasionally seen in Aberdare and Vale of Neath. $W$. Merthyr district. E. and F. Ystalyfera; Hirwaun. Ridd.

552. odorata, Mill. Fragrant Agrimony.

Admitted to T.B. on evidence of specimen by Purchas. Gower ; Penllergaer; Perddyn Glen. Ridd. in F. of G.

\section{Poterium, Linn. I19.}

553. Sanguisorba, Linn. Common Salad Burnet. Gwyddlwdn, Gwyddlwyn.

Common. Abundant. Native. Glareal, \&c.

\section{4. polygamum, Waldst. \& Kit.}

Local. Abundant. Alien. Agrestal, viatical, \&c.

Rhoose ! Aberthaw ! Llantwit Major ! Marcross ! Perhaps sown in all cases seen.

555. officinale, Hook, fil. Great Burnet. Llysuawg. Llysyrlys.

Local. Frequent, or even abundant. Native. Pratal, \&c.

Boggy pastures about Swansea. B.G. Cynon Valley; Pwllypant. J.S. Tyntyla; Tylacoch; Blaen-y-cwm! \&c. Flor. Rhondda. Ewenny. Miss B. Radyr. M.A.D. and $I$. Llandaff; Fairwater. I. Common at Aberdare. $W$. Merthyr district. E. and F. Wenvoe. J.S. (2). Craig-y-Llyn ! Lees. Phyt. I 843.

\section{Rosa, Linn. 120.}

556. spinosissima, Linn. Common Burnet Rose. Mwccog. Local. Abundant. Native. Glareal, \&c.

Frequent. Barry! Fontigary! Southerndown! J.S. Swansea Burrows! \&c. Lees. N.B.G. Candlestone sandhills! Miss, B. and V. 
Barry! D. and $H$. Barry Island! M.A.D., I., G.T. and V. I'orthkerry! $I$. and $H$. Common on all sandhills along Gower coast. $L$. Occurs all round the coast, on sand. T.H.T. A typical sand-clune plant, which never wanders far inland. $E d$.

559. mollis, Sm.

Vale of Neath. Flower of Lees. Phyt. i 843 . Cynon Valley, Near Aberdare. J.S. (2). Both records need confirmation.

560. tomentosa, Sm. Downy-leaved Rose. Rhosyn lledwlanog.

Local. Frequent. Native. Septal, \&c.

Not uncommon in hedges about Swansea. L.W.D. Mat. Penylan Lane; St. Fagans; Cynon Valley; Bridgend; \&c. J.S. Vale of Neath. Flower of Lees. Phyt. I 843. Dumbath Valley. Miss $B$. Barry. I. Barry Island. M.A.D. Pentyrch; Sully Road; the Garth. Y. Gelligaer. T.H.T. Llanmadoc; Pantyffynon to Pontardulais; Aberdare Valley; Caerphilly to Taff's Well. Ridd. This species and its segregates require further study.

561. rubiginosa, Linn. Eglantine. Rhoslwyn per. Mieri Mair.

Rare. Scarce? Native. Septal, \&c.

Near Aberdare; Llangynwyd; New house and Lisvane, J.S. Llanmadoc. Ridd.

562. micrantha, Sm. Small-flowered Sweetbriar.

Neddfechan Glen and Taff's Well. Ridd.

563. sepium, Thuill.

Whitchurch; Greenmeadow; Bonvilstone. J.S. In Ridd. F. of $G$., this is included under 562. The Editor has not yet recognised either rose in Glam.

564. obtusifolia, Desv.

Glyn Neath; Port Talbot; Llwydcoed. Ridd.

565. canina, Linn. Dog Rose. Ciros.

Common. Abundant. Native. Septal, \&c.

The numerous segregates of this aggregate species will be recorded in the appendix.

566. glauca, Vill. var subcristata, Baker.

Oxwich Bay and S. Cornely. Ridd.

567. stylosa, Desv. b. systyla (Bast). Columnar-styled Dog-rose.

Local. Frequent. Native. Septal.

Pennard Castle. Motley. Penylan ! St. Fagans ! Fairwater ! Pontypridd; Aberdare. J.S. Bodringallt; Penrhys. Flor. Rhondda. Between Pennard and Penrice. Phyt. I843. Aberdare; Vale of Neath. $W$. Gower; around Porthcawl; Nash Point to Llantwit Major; Ystradowen; Peterston; Lavernock. Ridd. Flemingstone! Cog! St. Fagans! Fairwater !

568. arvensis, Huds. White flowered Trailing Rose. Ciros gwyn. Common. Abundant. Native. Septal, \&c. 


\section{Pyrus, Linn. I2I.}

576. torminalis, Ehrh. Wilk Service-tree. Cerdelinen wyllt. Rare. Scarce. Native? Sylvestral.

Neath Valley; Penrice. B.G. Briton Ferry. L.W.D.Mat. A record which needs confirmation.

577. Aria, Ehrh. Common White Beam. Criafallen wen.

Local. Scarce. Native. Rupestral, \&c.

Neath Valley, Merthyr Tydvil. B.G. Nicholaston Wood. L.IV.D.Mat. Penrice. N.S.G.

b. rupicola, Syme. Oxwich Bay; Ysgwd Eynon Gam; Daren Bwllfa ; Padell-y-bwlch; Graig Fawr. Ridd. Craig-y-llyn ! above I,500 feet.

583. Aucuparia, Ehrh. Mountain Ash. Pren criafal. Cerddinen. Common. Abundant. Native. Rupestral, \&c.

584. communis, Linn. Wild Pear. Rhwning-bren. Rhwninen. Rare. Scarce. Native? Sylvestral, \&c.

Leckwith, Barry, Porthkerry, \&c. J.S. Aberdare. Ridd. Penylan. $M r$. Chapman, spu.! Hedges about Slade, Southerndown. Miss B. Not found at Barry. D. Pontcanna. M.A.D., V. and $I$. Porthkerry; Penarth. $H$.

586. Malus, Linn. Common Crab Apple. Afallen.

Common. Frequent. Native. Septal and sylvestral.

Leckwith, Llandough, Lavernock, \&c. J.S. Bodringallt, Pontygwaith. Flor. Rhondda. Norton, Southerndown. Miss B. and $V$. Barry. D. Fairwater. $I$. Aberdare. $W$. Penarth! $H$. Merthyr district. $E$, and $F$. Common in woods in Kittle, Green Cwm, \&c., Gower. L. Sully, St. Brides. $V$. Both varieties are, I believe, about equally common, of similar status, and spread all over the county.

a. acerba, DC. Pop Hill ! Peterston !

b. mitis, Wallr. Pop Hill ! Peterston!

\section{Cratægus, Linn. 122.}

588. Oxyacantha, Linn. Hawthorn. Draenen wen. Yspaddaden. Egfaenwydd.

Common. Abundant. Native. Septal, \&c.

\section{Cotoneaster, Medic. I23.}

\section{microphylla, Wallich.}

Wild at Caerphilly and Cornely. Rev. IW. F. Evans, J. of B. 1905. Near ruins in several places. Ed. 


\section{Saxifrageæ.}

\section{Saxifraga, Linn. 124 .}

595. umbrosa, Linn. London Pride.

Thoroughly established and abundant on a Railway Embankment near Hengoed.

598. tridactylites, Linn. Rue-leaved Saxifrage. Tormaen tribys.

Local. Abundant. Native. Glareal.

Roath; Llandaff. J.S. Roath Farm. Nat. Hb. Ogmore Common. Miss B. Barry! D. Caerphilly; St-y-Nil. : Llandaff ; \&c. M.A.D. Southerndown. I. and V. Porthcawl. I. Coedriglan. $H . E$. Vale of Neath. W. Merthyr district. E. and F. Common in Gower. L. Llantrithyd; St. Donats; St. Lythans. G.T. Dean Farm, Roath; St. Nicholas. V. Little Garth. T.H.T. Jersey Marine; Pontneddfechan; Aberthin. Ridd. Dinas Powis ! Cwrtyr-Ala ! Sully ! Penarth ! Leys ! Newton Nottage ! Porthcawl ! Sometimes so abundant as to give a reddish colour to the vegetation of the dunes.

60 I. granulata, Linn. White Meadow Saxifrage. Llyfenwy. Clor y brain. Tormaen gwyn.

Rare. Scarce. Native. Pascual?

Between 'Taff's Well and Pontypridd. J.S. Aberdare; Pontsarn. Ridd. Pontcanna. M.A.D., I, and $V$. St. Fagans. I. Abercynon. $W$. Extinct in Merthyr district. E. and $F$. Plentiful in Ilston Cwm. L. Several additional records for habitats on the borders of Glam., but in Brecon.

607. hypnoides, Linn. Cut-leaved Saxifrage.

Local. Frequent. Native. Rupestral.

Mountain E. of Pontneddfechan (probably Craig-y-llyn), B.G. Merthyr. Nat. Hb. Morlais Castle! Craig-y-llyn! U.C. Hb. Craigy-Llyn; Rhigos; Padell-y-bwlch! Hirwain. W. Merthyr district. E. and F. Morlais Castle! T.H.T. Graig Fawr, Treorky! Ridd.

\section{Chrysosplenium, Linn. 125.}

6o8. oppositifolium, Linn. Opposite-leaved Golden Saxifrage. Eglyn cyferbynddail.

Common. Abundant. Native. Uliginal.

609. alternifolium, Linn. Alternate-leaved Golden Saxifrage.

Rare. Scarce. Native. Uliginal.

Rare. Llanishen; Heol-y-mynydd. J.S. Merthyr Tyclvil; R. Perddyn. Ridd. Near Llanishen, now extinct. Mr. Chapman. Southerndown, not common. Miss $B$.

\section{Parnassia, Linn. 126.}

6ı. palustris, Linn. Grass of Parnassus. Brial y gors.

Rare. Scarce. Native. Paludal.

Llanishen. J.S. Now extinct at Llanishen. V. Pwllypant. J.S. Rhondda Valley. Flor. Rhondda. 


\section{Ribes, Linn. 127.}

611. Grossularia, Linn. Gooseberry. Grwyswydd.

Local. Frequent. Denizen. Septal, \&c.

Taft and Ely Valleys. J.S. Candlestone Wood. Miss B. Barry. $D$. Pontcanna. M.A.D. St. Fagans. I. Aberdare and Vale of Neath. $W$. Ilston Cwm. $L$. Pendoylan. $V$. Wood near Llanishen. T.H.T. Near Maeslech Farm. J.E. Wrinstone! \&c., perhaps in every parish in the County.

612. alpinum, Linn. Tasteless Mountain Currant. Rhyfwydden mynyddawl. Eirin Mair.

Marked with the sign of doubt? in T.B. Said to occur in Glamorgan in Eng. Bot., 3rd Ed. St. Donats; Caerphilly Castle. J.S. Recent records and specimens are necessary in this case, otherwise the species must be excluded.

613. rubrum, Linn. Red Currant. Rhesinwydd goch.

Rare. Scarce. Native. Sylvestral, \&c.

Taff, Rumney, and Ely Valleys, as outcast ? J.S. Candlestone Wood. Miss B. Pontcanna. M.A.D. Wood near Llanishen. T.H.T. Garth Wood; Aberdare; Ystradowen. Ridd.

61 4. nigrum, Linn. Black Currant. Rhesinwydd ddu.

Rare. Scarce. Native. Paludal, inundatal, \&c.

Taff, Ely, and Ddaw Rivers. J.S. Pendoylan. M.A.D. and V. Ilston Cwm. L. Oxwich; Parkmill ; Pontardulais ; Wenvoe ; Aberdare; Caerphilly; \&c. Ridd. Taff's Well! in old mill pond with typical paludal plants. Gigman Bridge ! on boggy ground. Beauville! near Dinas Powis.

\section{Crassulaceæ,}

Cotyledon, Linn. 129.

6 I6. Umbilicus, Linn. Common Navel-wort. Cron-cloddaidd. Bogail Gwener. Bogail y forwyn.

Common. Abundant. Native. Rupestral.

\section{Sedum, Linn. I30.}

617. roseum, Scop. Roseroot. Pren y ddanodd.

Rare. Abundant. Native. Rupestral.

Craig-y-Llyn! D. Llewelyn, L.W.D.Mat., Ridd.F. of G., U.C.Hb., IV., T.H.T. and J.S. (2).

6ı8. Telephium, Linn. b. Fabaria, Koch $=S$. purpureum Tausch.

Orpine. Bywlys llydanddail. Llysiau Taliesin. Canhewin. Local. Frequent. Native. Rupestral.

Llanishen; Cowbridge; Llantwit Major. J.S. Llandwr Marsh. Phyt. 1842. p. 108. Cefn Mably. H.E. Craig-y-Llyn ! Padelly-bwlch. IV. Machen Woods. E. and F. Ilston Cwm. L. Pwllypant. $V$. Frequent on Gower Coast. Ridd. Graig Fawr, Treorchy, 
I 898. U.C. Hb. Most of the records were sent in under the aggregate $S$. Telephium, Linn, but all probably belong to the second segregate, as given above.

6r9. villosum, Linn. Hairy Stonecrop.

Collected somewhere near Glyncorwg. J.S. Needs confirmation.

620. album, Linn. a. teretifolium (Haw.). White Stonecrop.

As an alien at St. Hilary! G.T. and J.S. (2). Near How Mill. J.S. (2). Pentyrch. V. Llanmadoc; Mawdlam. Ridd.

b. micranthum (Bast).

On limestone rocks in Cwm Alun ! looking like a native, and certainly so different from the preceding as to merit specific rank.

622. anglicum, Huds. English Stonecrop. Briweg y cerrig. Local (or Rare). Frequent (or Scarce). Native. Rupestral.

Port Eynon. N.S.G. Frequent. Sully; Barry; Porthkerry; Fontigary; \&c. J.S. Pontygwaith Bridge. Flor. Rhondda. Old Walls, Southerndown. Miss B. Dinas Powis, \&c. $H$. Summit of Worms Head and all round coast of Gower. T.H.T. Not uncommon. $V$. Common. H.E. There is a manuscript record for Glam. by E. F. Linton, 1907. A.B. This is a very interesting record. The species has always been regarded by me as common, as it is so abundant in some Welsh counties. In recent years, however, I have looked for it in vain in Glam. Mr. Riddelsdell gives no record of his own, and very few of any kind. Is the plant really rare, or local ? It is possible that it is rapidly dying out.

623. acre, Linn. Biting Stonecrop. Bywydog boeth. Bywlys. Common. Abundant. Native. Glareal and rupestral.

624. sexangulare, Linn. Insipid Stonecrop.

On a steep rocky bank, near the source of the Afan. Mr. Motlcy. L.W.D.Mat.

625. reflexum, Linn. Yellow Stonecrop. Bywydog llwynau'r fagwyr. Local. Frequent. Alien. Rupestral.

Peterstone Castle; St-y-Nil. J.S. Common on walls (about Swansea). Phyt. I842. Cowbridge. D. St.-y-Nil. V. Lougher; Penllergaer; Ystalyfera. Ridd. Southerndown! Dinas Powis ! Sully! \&c. ; all escapes, no doubt.

627. Forsterianum, Sm. Forster's Stonecrop.

Rare. Scarce. Native. Rupestral.

Banks of Neath Canal. Gutch. Phyt. I 842. Craig-y-Llyn ! I890. U.C. Hb. Cliff at Craig-y-Llyn. I890. Augustin Ley. Record communicated by A.B. Not found there since. Did Mr. Ley collect it? I saw one small patch only.

\section{Sempervivum, Linn. $13 \mathrm{I}$.}

628. tectorum, Linn. Common House Leek, Bywfyth. Llys pentai. Rare. Scarce. Alien. Rupestral.

St. Nicholas; Barry; Cadoxton. J.S. Heol-y-mynydd ! Colwinstone. Miss B. Rhossili. D. Merthyr. E. and F. Grangetown; Whitchurch; Llancaiach, $V$. 


\section{Droseraceæ.}

\section{Drosera, Linn. 132.}

629. rotundifolia, Linn. Round-leaved Sundew. Tawddrudd crynddail. Gwlithlys. Toddaidd rudd.

Local. Frequent. Native. Uliginal.

Crymlyn Bog and Cwm Bychan: L.W.D.Mat. Frequent. Llanishen; Caerphilly! Pontypridd; \&c. J.S. Mardy; Pontygwaith. Flor. Rhondda. Llanishen. D. Ystradowen! M.A.D. and V. Pendoylan. M.A.D., $I$, and $V$. Rhigos; Hirwaun Common! $W$. Taff's Well. $H$. Merthyr district. E. and $F$. Llanharry. G.T. Frequent in Gower; Llyn-fach; near Aberdare; Cwmparc. Ridd. Blaenrhondda! Not abundant anywhere.

630. anglica, Huds. Larger Long-leaved Sundew. T. hirddail. Extinct? Native. Uliginal.

On Crymlyn Bog, where, before the drainage, it was often found mixed with the other two more common species. L.W.D.Mat. Town Hill, Swansea. Gutch. Phyt. 1843.

63I. intermedia, Hayne. Lesser Long-leaved Sundew. T. hirddail. Local. Frequent. Native. Uliginal.

Crymlyn Bog. B.G. Llangynwyd; Blaen-y-cwm. J.S. Cwm Bychan. Phyt. I842. Gutch. Pendoylan! $I$. and $V$. Near Pencoed. J.S. (2): Could not find it at Llangynwyd. T.H.T. Mynydd-y-Glew. Miss Nicholl. Rhossili ; Cefn Bryn; Clyne Common; Gowerton Common; Ystradowen. Ridd.

\section{Haloragea.}

\section{Hippuris, Linn. 133 .}

632. vulgaris, Linn. Common Mare's Tail. Rhawn y gaseg cyffredin. Local. Frequent. Native. Lacustral.

Frequent. Penylan! Leckwith. J.S. and T.H.T. Marsh near Neath Canal. Phyt. I842. Ewenny! Miss $B$. River Thaw! $D$. Merthyr Mawr. M.A.D., $I$. and $V$. Hirwaun Common. $W$. Common in Gower. L. St.-y-Nil ! V. Cowbridge. J.S. (2). Crymlyn Bog and Temnant's Canal ; Llangenydd; Oxwich ; Margam Marshes. Ridd. Abundant near Ogmore Castle!

\section{Myriophyllum, Linn. I34.}

633. verticillatum, Linn. Whorled Water Milfoil. Myrdd ddail troellog.

Leckwith, E. Moors, \&c. J.S. Doubtful record, needing confirmation. 
634. spicatum, Linn. Spiked Water Milfoil. Myrdd ddail tywysenaidd.

Local. Abundant. Native. Lacustral.

Rare. Leckwith reens; River Thaw; \&c. J.S. Crymlyn Bog. Phyt. I 842. Llandaff Weir pond. M.A.D. Llandaff; Pendoylan! Waterhall. I. Hirwaun. W. Merthyr district. E. and F. Grangetown; St. Fagans. J.S. (2). Oxwich and other places in Gower; Penllergaer and Pontardulais; Resolven; Port Talbot; Aberdare ; Ystradowen. Ridd. Penylan! Roath Park Lake ! Reens about Cardiff ! and Leckwith! Sully Moors! Cadoxton Moors ! Kenfig Pool! Backwaters of River Ely! \&c.

635. alterniflorum, DC. Alternate-flowered Water Milfoil.

Local. Frequent. Native. Lacustral.

Pitton; Llyn-fach; Aberdare; Merthyr Tydvil; Welsh St. Donats; St. Fagans. Ridd.

\section{Callitriche, Linn.}

636 to 640 comprise the old aggregate species Callitriche verna $L$. -the Vernal Water Starwort-which is common and abundant throughout the district. Storrie's record is for the aggregate species.

636. verna, Linn (= c. vernalis, Koch.)

Near Ogmore Castle!! Llantwit Major ! Leckwith Moors !

637. stagnalis, Scop.

Hensol !! Pop Hill ! Sully Moors ! Leckwith Moors ! Grangetown ! Beaupré ! ! \&c. Ed. Crymlyn Bog; Ystalyfera; Llanbleddian; Cadoxton; Barry; Bonvilstone; Aberdare; Caerphilly, \&c. Ridd.

639. hamulata, Kuetz.

Crymlyn Bog; Llynfach; Port Talbot Docks; Aberdare to Hirwain; Caerphilly. Ridd.

var. pedunculata, DC. Port Talbot. Marshall \& Shoolbred. $J$. of B. 1902. Swansea. E. F. Linton. J. of B. 1886. Pitton ; Ystradowen; Aberdare. Ridd.

640. obtusangula, Le Gall.

River Ddaw ! ! Leckwith Moors ! Lavernock ! Near Ogmore Castle ! Ed. Between Pyle and Port Talbot. Marshall \& Shoolbred. $J$. of B. I902. Near Flemingstone. U.C. Hb. Crymlyn Bog; Margam Moors; Cowbridge. Ridd.

641. autumnalis, Linn. Autumnal Water Starwort. Brigwlydd.

Leckwith and Cadoxton. J.S. This and other records are almost certainly erroneous. Ed. 


\section{I. Lythrarieæ.}

\section{Peplis, Linn. 136.}

643. Portula, Linn. Water Purslane. Porpin. Troed y gywen.

Local. Frequent. Native. Uliginal and inundatal.

Not Common. Cefn On ; Pontypridd! J.S. Llandwr Marsh. Gutch. Phyt. 1842. Hirwaun Common. $W$. Merthyr district. $E$. and $F$. Pendoylan. $I$. and $V$. Fairwood Common; Pennard Burrows, \&c. L. Mynydd Garngoch ; Loughor Down ; Crymlyn Burrows; Neath; Port Talbot; Ystradowen. Ridd. Upper Boat. spn.! Mr. Chapman. Hensol!

\section{Lythrum, Linn. 137.}

644. Salicaria, Linn. Purple Loosestrife. Gwyrarllys. Llys y milwr. Local. Frequent. Native. Paludal.

Frequent. Rumney Moors; Cadoxton; Sully; St. Fagans ; \&c. J.S. Frequent. Blaenrhondda; Ynyshir. Flor. Rhondda. Ewenny River Banks! Miss $B$. Barry! scarce. D. Ystradowen! Radyr. M.A.D. Aberdare; Vale of Neath. $W$. Fairly common in Gower; Ilston Cwms, \&c. L. Banks of Ogmore! and Thaw ! T.H.T. Swanbridge and Lower Penarth ! V. Cwrt-yr-Ala ! Taff's Well! Treforest ! Llansanwr ! Cowbridge ! Ystradowen ! Peterston ! \&c., \&c.

\section{Onagrarieæ.}

\section{Epilobium, Linn. 138.}

646. angustifolium, Linn. Rose-Bay. Helyg-llys hardd.

Local. Abundant. Native. Sylvestral, rupestral, \&c.

Frequent. Caerau; Caerphilly Tunnel; Cynon Valley; \&c. J.S. Not common. Ynyshir; Blaenycwm. Flor. Rhondda. Barry, not common. D. Taff's Well! M.A.D., V. and T.H.T. Aberdare ! $W$. Merthyr district. $E$. and $F$. Pendoylan. $I$. and $V$. Llancaiach. $V$. Immense groups on ballast near Aberdare and Hirwaun ; near Neath. T.H.T. Fairwood Common; Gowerton; Craig-yLlyn ! Aberafan; Nash Point; Llantwit Major; Llandough. Ridd. Llansanwr ! Ystradowen! Lisvane ! Eglwysilan! Cow. bridge! Newton Nottage Burrows ! \&c.

647. hirsutum, Linn. Great Hairy Willow-Herb. H. pêr. Common. Abundant. Native. Paludal.

$\times$ montanum. Aberdare, Ridd.

$\times$ parviflorum. Cathays Park. $V$. This hybrid is frequent in the S.E. of Glamorgan, e.g., near Cogan Hall, Merch, Dinas Powis, Wrinstone, Cwrt-yr-Ala, \&c., growing with its parents, 
648. parviflorum, Schreb. Small flowered Hairy IVillow-Herb, H. lledlwyd manflodeuog.

Common. Abundant. Native. Paludal.

$\times$ roseum. Aberdare. Ridd.

649. montanum, Linn. Broad-leaved IVillow-Herb. H- llyfn llyclan ddail.

Common. Abundant. Native. Sylvestral, viatical, \&c.

x obscurum. Swansea. E. F. Linton. J. of B. 1892. Aberdare. Ridd.

$\times$ parviflorum. Aberdare. Ridd.

$\times$ roseum. Swansea. E. F. Linton. J. of B. 1892. Aberdare. Ridd.

650. lanceolatum, Seb. \& Maur. Spear-leaved Willow-Herb.

Aberafan ; Aberdare. Ridd.

65I. roseum, Schreb. Small-flowered Smooth Willow-Herb.

Local. Frequent. Native. Sylvestral.

Banks of Neath Canal near Port Tennant. Gutch. Phyt. 1842. Swansea. E. F. Linton. J. of B. 1892. Neath; Baglan; Aberdare. Ridd. Llanfabon! U.C. Hb.

652,653 , and 654 represent the segregates of the aggregate species E. tetragonum, Limn. The segregates are still imperfectly known in Glamorgan. and require more detailed study.

tetragonum, Linn. Square-stalked Willow-Herb. H. pedrongl. Local. Frequent. Native. Paludal, \&c.

Frequent. Dinas Powis; Cadoxton. J.S. and T.H.T. Tyntyla ; Bodringallt, \&c. Flor. Rhondda. Neath Canal, near Port Tennant. Gutch. Phyt. 1842. Ewenny. Miss B. Barry. D. Lavernock! M.A.D. Aberdare; Vale of Neath. $W$. Penarth and Cwrt-yr-Ala. H. Caerphilly. V. St. Donats ! Pontypridd Common!

652. adnatum, Girisebach.

Port Talbot; Aberdare; Lavernock! Grangetown; Caerphilly. $\times$ obscurum. Port Talbot; Aberdare. Ridd.

\section{3. obscurum, Schreb.}

Probably most of the records given under E. tetragomum, Linn. Frequent. Ridd.

655. palustre, Linn. Narrow-leaved Marsh Willow-Herb. H. culddail y fawnog.

Local. Frequent. Native. Paludal.

Llanishen, \&c. J.S. Near Crymlyn. E. F. Linton. J. of B. I 890. Merthyr Mawr. Miss B. Aberdare; Vale of Neath. $W$. Merthyr district. E. \& $F$. Gower; Penllergaer ; Margam ; Barry ; Graig Fawr ; Treorchy; Llantrisant ; Ystradowen ; Caerphilly ; \&c. Ridd. Treherbert ! Craig-y-Llyn ! about I,600 feet high; St. Hilary ! 


\section{Enothera, Linn. 140.}

659. biennis, Linn. Common Evening Primrose.

Local. Frequent. Alien. Glareal, viatical, \&c.

Formerly on the sandhills near Swansea. L.W.D.Mat. Frequent. Pentyrch; Maesteg; Sophia Gardens; Cooper's Fields; \&c. J.S. Briton Ferry. Flower \& Lecs. Phyt. 1843. Newton Nottage ! Miss B. Barry! D. and J.S. (2). Taff's Well! M.A.D., H., T.H.T. and $V$. G.W. Railway at Aberdare and Hirtwaun. $W$. Merthyr district. $E$. and $F$. St. Georges. $I$. Sandhills at Oxwich. $L$. Banks of River Taff. G.T. Ystradowen! Pencoed!

660. odorata, Jacq.

Porthcawl. N. and also Cundall. J. of B. 1902. p. 316. Port Talbot: Cardiff Docks. Ridd.

\section{Circæa, Linn. 141 .}

66r. Lutetiana, Linn. Common Enchanter's Nightshade. Swynydlllys. Llys Stephan.

Common. Abundant. Native. Sylvestral, \&c.

\section{Cucurbitaceæ.}

\section{Bryonia, Linn. 142.}

663. dioica, Jacq. Red-berried Bryony. Greol. Eirin gwion. Wynwydden wen.

Rare. Scarce. Native. Septal.

Sophia Gardens Field ! Castell Coch. J.S. Rare in Gower. Srransea Sci. Soc. Proc. 1895-6. p. 96. Castell Coch. M.A.D. Around Pontypridd and Vale of Glamorgan. $E$. and $F$. One plant in hedge on Cowbridge Road, near Ely. T.H.T. Ely, near old Rope Walk. J.S. (2). On Merthyr Road, near Whitchurch. $V$. St. Fagans !

\section{Umbelliferæ.}

\section{Hydrocotyle, Linn. 143.}

664. vulgaris, Linn. Marsh Pennywort. Amrain.

Common. Abundant. Native. Uliginal.

\section{Eryngium, Linn. 144.}

665. maritimum, Linn. Sea Holly. Boglynon arfor. Morgelyn. Local. Frequent. Native. Littoral.

Frequent. Sully, Penarth, Barry, Leys ! J.S. Probably extinct in the first two places. Ed. Sandhills at Swansea, Crymlyn Burrows and Singleton, Gutch. Phyt. i842. p. r19. Sandhills at 
Newton! not frequent. Miss $B$. Common at Barry. $D$. The Leys ! M.A.D. and $V$. Porthcawl ! H. Monknash. G.T. Aberthaw ! M.A.D. and T.H.T. Port Eynon. T.H.T. Oxwich; Broughton Burrows; Pennard; Crymlyn Burrows. Ridd. Near Culver Hole. S.S. Proc. 1892-3. p. 23. Port Talbot! 1905.

666. campestre, Linn. Ysgall canpen.

Old Artillery Range, abundant. J.S. Now extinct. Status doubtful. This site is now occupied by the Roath Dock, \&c. Port Talbot-in three places. Ridd.

\section{Sanicula, Linn. 146.}

668. europza, Linn. Wood Sanicle. Golchwraidd. Y dileilen dla. Common. Abundant. Native. Sylvestral.

\section{Conium, Linn. 148.}

670. maculatum, Linn. Common Hemlock. Cegirlen gyffredin.

Local. Abundant. Native. Sub-littoral, \&c.

Frequent. Penarth! Sully! Barry! Dinas Powis ! \&c. J.S. Swansea. Phyt. I842. Southerndown, abundant. Miss B. Common at Barry! D. and $H$. Llantrithyd. M.A.D. Sully ! H. Very common in Gower. L. Llandough, Cowbridge. G.T. Castell Coch, \&c., common. V. Boverton; Ely Bridge. J.S. (2). Aberafan; Nottage, and Merthyr Mawr; Taff's Well ; Caerphilly Castle. Ridd. Barry Island! Llantwit Major ! Southerndown! Penlline! Affects the coast and occurs apparently on all the geological formations-very fine and abundant on the Triassic conglomerate at Sully.

\section{Smyrnium, Linn. 149.}

671. Olusatrum, Linn. Common Alexanders. Dulys cyffredin. Alis antr y ddulys.

Local. Abundant. Native? (or Denizen). Viatical, \&c.

Common. Penarth ! Leckwith ! Swanbridge ! \&c. J.S. Southerndown, common. Miss B. Common at Barry. D. Fairwater. M.A.D. Lavernock! H. St. Donats! G.T. Marcross! $V$. In Gower, abundant about ruins; on Flat Holm. T.H.T. Oystermouth: Broughton Bay; Rhossili; Llangenydd; Briton Ferry; S. Cornely; Ogmore Castle ; Aberthaw. Ridd. Cog, very abundant! Lower Penarth! and many other places, the plant being regarded as too common to be noteworthy.

\section{Bupleurum, Linn. I50.}

674. tenuissimum, Linn. Slender Hare's Ear.

Rare. Frequent. Native. Sub-littoral.

Ely Estuary ! V. and M.A.D. First noted in 1905. Near mouth of River Rhymney. McCulloch. J.S. (2). The plants are easily overlooked, and in no way associated with the ballast. 


\section{Apium, Linn. 152.}

677. graveolens, Linn. Wild Celery. Mers. Halogan. Pêrllys yr hel. Local. Frequent. Native. Sub-littoral.

Frequent. Penarth ! Leckwith ! Burton Bridge, \&c. J.S. Ewenny! Miss B. Leckwith. M.A.D. Not uncommon near Park Mill, Gower. L. Pengam Moors! Fontigary! Southerndown ; near Cardiff Docks ! V. Loughor; Pontardulais; Swansea; Neath ; Port Talbot, \&c. Ridd. Around the estuaries of all our rivers from the Rhymney to the Loughor.

678. nodiflorum, Reichb. fil. Procumbent Water Parsnip. Dyfr foronyn sypflodeuog.

Common. Abundant. Native. Paludal, \&c.

This plant varies from specimens six feet high to others of a few inches. Storrie appears to have exchanged the names of 678 and 679 .

var. pseudo-repens, H. C. Wats. Clyne Common. Ridd. Small pond, near Sker Farm! The records of Ball and Motley for Pennard Castle and Kenfig Pool respectively, appear to refer to this variety and not to the true repens.

679. inundatum, Reichb. fil. Least Water Parsnip. Amrain dyfrdrig. Local. Abundant. Native. Lacustral.

Common? E. Moors, Grangetown, \&c. J.S. Fontigary, Barry. D. Pwll-Arthur, St. Fagans. M.A.D. Pendoylan! M.A.D. and $V$. Cefn Bryn; Fairwood Common; Gowerton Common. Ridd. Swansea. E. F. Linton. J. of B. 1886. St.-y-Nil! Hensol! Leckwith Moors! Grangetown Moors !

\section{Carum, Linn. 155.}

682. verticillatum, Koch. Whorled Caraway.

Local. Abundant. Native. Pratal.

Abundant near Cwmbola (? Cwmbwrla) Bridge, Penllergaer and Drymma. Gutch. Phyt. I842, p. I I9; St. Lythans. J.S. Rhigos. Hirwaun Common. $W$. Near Catersford, rare. L. Loughor river. basin, very common; Ystalyfera; hills near Pontneddfechan ; Cwm Mawr, Ridd. Pontardulais!

683. Petroselinum, Benth. \& Hook. fil. Common Parsley. Perllys. Persyll.

Rare. Scarce. Native? Rupestral.

Swanbridge! J.S. In this single station it persists year after year in its wild form, exactly similar to that which occurs on the rocks near the Clifton Suspension Bridge, Bristol.

684. segetum, Benth. \& Hook. fil. Corn Parsley.

Local. Frequent. Native? Agrestal, septal, \&c.

Hayes Farm ! collected in 1899. U.C. Hb. Growing in a corn field and on side of a new road, near the Barry Docks Hydraulic Power Shed. No longer there, apparently, in 1907. Ed. Mawdlam to S. Cornely and Nottage ; Barry; Merthyr Dyfan; Swanbridge. Ridd. 
Sison, Linn. 156.

687. Amomum, Linn. Hedge Stonewort.

Local. Abundant. Native. Septal, \&c.

About Swansea. Flower \& Lees. Phyt. I 843. Barry! frequent. $D$. Gileston! M.A.D. and $V$. Lavernock! $N$. Lower Penarth ! Sully Road ! $V$. S. Cornely to Nottage. Ridd. Practically all through the Vale of Glamorgan; Pop Hill ! Cadoxton Moors ! Marcross ! St. Donats! Llantwit Major ! Llandough! Michaelstonele-Pit! Peterstone!

\section{Sium, Linn. 157.}

689. Latifolium, Linn. Great Water Parsnip. Dyfr foronyn llyclanddail.

Many records, all doubtless referring to luxuriant specimens of No. 690.

690. erectum, Huds. Water Parsnip. Dyfr foronyn cul-ddail.

Local. Frequent (or abundant). Native. Paludal.

East Moors ! Penarth Road ! Leckwith ! J.S. but recorded by him under 689. Common, Barry. D. Park Mill; Oxwich ; Broughton Bay; Llanrhidian; Loughor Marshes; Crymlyn Bog; Jersey Marine; Margam Moors. Ridd. Near Ogmore Castle ! Welsh St. Donats ! Llantwit Major ! Sully! Michaelstone-le-Pit ! Pop Hill ! River Ddaw, abundant and very fine ! Ely Estuary ! Llansanwr ! Cowbridge! \&c.

\section{Egopodium, Linn. 158.}

691. Podagraria, Linn. Common Goutweed. Llys y gymmalwst.

Local. Abundant. Native? Viatical.

Not very common. Churchyards at Cardiff and Llantwit Major; near Coedygoras; \&c. J.S. Tylacoch. Flor. Rhondda. Southerndown. Miss B. Fairwater. M.A.D. and I. Aberdare. IV. Park Mill. L. Penllergaer. G.T. Boverton; St. Hilary. J.S. (2). Common about Cardiff. $V$. Llanedeyrn Churchyard. T.H.T. Probably native in Perddyn Gorge. Ridd. Llanilid ! St. Donats! Sully! \&c., \&c.

\section{Pimpinella, Linn. 159.}

692. Saxifraga, Linn. Common Burnet Saxifrage. Gwraiddiriog cyffredin.

Common. Abundant. Native. Pascual.

\section{Conopodium, Koch. I60.}

694. denudatum, Koch. Common Earth Nut. Bywi. Cneuen y ddaear.

Common. Abundant. Native. Sylvestral and pratal. 
Myrrhis, Linn. I6I.

695. Odorata, Scop. Sweet Cicely. Creithig ber. Sisly ber.

Rare. Scarce. Alien. Septal, \&c.

Hilly Pastures. L.W.D.Mat. Cwmffrwdor. E. Lees, J.S. Aberdare; Merthyr Tydfil. Ridd. Cooper's Fields. IV. W. Pcttigrew and $V$. Llancaiach. $V$. Cwm Glais, Merthyr Tydvil. T.H.T. Vale of Neath. N. Ilston, Gower. $L$.

Chærophyllum, Linn. 162.

696. temulum, Linn. Rough Chervil. Gorthyfail garw.

Common. Abundant. Native. Septal.

Scandix, Linn. I63.

697. Pecten=Veneris, Linn. Common Venus'-Comb. Creithig nodwydd y bugail.

Common. Abundant. Colonist. Agrestal, \&c.

Anthriscus, Bernh. 164.

698. vulgaris, Bernh. Common Chervil. Creithig gwrychog.

Rare. Scarce. Native. Viatical, \&c.

Very rare. Near Cardiff and Penarth. J.S. Llanmadoc cliffs. Ridd. Llanmadoc. $V$. Candlestone. M.A.D. and $V$.

699. sylvestris, Hoffm. Wild Chervil. Gorthyfail llyfn.

Common. Abundant. Native. Septal and sylvestral.

Fœniculum, Linn. 166.

702. vulgare, Mill. Common Fennel. Ffenigl cyffredin.

Local. Frequent. Native (but not always). Rupestral and sublittoral.

Frequent. Sully ! Barry ! Dunraven. J.S. Porthcawl ! Cundall. Dunraven; Newton. Miss B. Common at Barry! $D$. Sully ! M.A.D., $H$. and $V$. Aberdare. $W$. Georgetown tips, Merthyr. $E$. and $F$. Not uncommon near Park Mill. $L$. Around various inlets in Gower. T.H.T. Loughor; Jersey Marine; S. Cornely. Ridd. Port Talbot! Aberthaw! Cold Knap! Swanbridge! Dinas Powis ! \&c. Seldom grown in gardens and often abundant where it could not possibly be an outcast.

\section{Crithmum, Linn. 167.}

703. maritimum, Linn. Rock Samphire. Corn carw y mor. Ffenigl y mor.

Local. Abundant. Native. Littoral.

Frequent. Swanbridge; Sully ; Barry; Dunraven. J.S. Common on the rocks of the coast from Cardiff to Loughor-whether mountain limestone, triassic conglomerate, or liassic limestone; also on pebble beaches and breakwaters. 


\section{Enanthe, Linn. 168.}

704. fistulosa, Linn. Common Water Dropwort. Libynlor pibellaidd. Local. Frequent. Native. Paludal.

Common. Grangetown, E. Moors, \&c. J.S. and T.H.T. Glyncornel; Bodringallt; \&c. Flor. Rhondda. Singleton. Phyt. I842. Common at Barry! D. Frequent, Fairwater. M.A.D. Aberdare; Vale of Neath. $W$. Near Park Mill, \&c. L. Flemingstone Moor; Lisvane. Ridd. Penylan! St.-y-Nil ! Cwrt-yr-Ala ! Sully Moors ! Cadoxton Moors! and many other places, being too common to attract special attention.

707. Lachenalii, C. Gmel. Parsley Water Dropwort. Dibynlor per llys ddail.

Local. Abundant. Native. Paludal.

Has been generally mistaken for, and recorcled under the name of E. pimpinelloides, Limn. (No. 705) - a much rarer British plant, not yet recognised in Glamorgan.

Kenfig Pool. Motley. Landore. L.W.D.Mat. Reens near Cardiff! J.S. Merthyr Dyfan; Cadoxton; \&c. Ridd. Near Pennard Castle. Ball. Bot. Gaz. Barry! and Gilestone! D. Ely Common reens. M.A.D. Llandough, near Cardiff. G.T. Lavernock Road; Roach Ponds, Cardiff. $V$. Ely, Thaw, and Ogmore Estuaries; inland at Pop Hill, Cogan Hall, Dinas Powis, but never far from the sea. $E d$.

708. crocata, Linn. Hemlock Water Dropwort. Dibynlor cegidaidd. Gysplys.

Common. Abundant. Native. Paludal.

\section{Athusa, Linn. 160.}

71 I. Cynapium, Linn. Common Fool's Parsley. Gauberllys.

Local. Frequent. Native. Agrestal, viatical, \&c.

Frequent. Roath Church; Penarth; \&c. J.S. and T.H.T. Pontygwaith; Aberllechau Woods. Flor. Rhondda. A common weed about Swansea. Phyt. 1843. Flower \& Lees. Southerndown. Miss B. Llandaff. M.A.D. Hirwaun. W. Penarth! Sully! $H$. Near Park Mill, Gower. L. About Cardiff ! V. Penclawdd; Loughor; Port Talbot; Porthcawl; Aberthaw; Ystradowen ; Caerphilly, \&c. Ridd. Barry! Dinas Powis ! Llantwit Major ! and many other places.

\section{Silaus, Bess. 171 .}

7 I3. flavescens, Bernh. Meadow Sulphur Wort. Ffenigil y môch. Local. Abundant. Native. Pratal and pascual.

Gileston ! M.A.D. Merthyr district. E. and $F$. Valley of Thaw! abundant. Mrs. Rice Nicholl. Common about Penarth! and Lavernock ! V. Pyle; Aberdare. Ridd. Cogan ! Dinas Powis! Barry! Llandough! St. Fagans! and many places in the Vale of Glamorgan. 


\section{Angelica, Linn. 175 .}

717. sylvestris, Linn. Wild Angelica. Llys yr Angel y goedwig. Ysgyfaintlys.

Common. Abundant. Native. Paludal, \&c.

\section{Peucedanum, Linn. I77.}

722. sativum, Benth. \& Hook. f. Wild Parsnip.

Local. Abundant. Native. Sub-littoral, viatical, \&c.

Frequent. Leckwith; St. Nicholas; \&c. J.S. About Swansea. Flower E Lees. Phyt. 1843. p. 378. About Southerndown, common. Miss B. Penarth ! H. and M.A.D. Lower Grangetown. V. Barry ! Very abundant on cliffs near Penarth, and also on new roads in the neighbourhood, where it has flourished for at least I5 years.

\section{Heracleum, Linn. 178.}

723. Sphondylium, Linn. Common Cow Parsnip. Efwr cyftredin. Common. Abundant. Native. Septal, \&c.

b. angustifolium, Huds. Cefn On. $M r$.Chapman, sp.! U.C.Hb. Penmaen; Aberdare; Lisvane. Ridd. Llanharry !

\section{Daucus, Linn. I8I.}

726. Carota, Linn. Wild Carrot. Moronyn y meusydd. Meddyglyn. Nyth yr aderyn.

Common. Abundant. Native. Pascual, sub-littoral, \&c.

727. gummifer, Lam. Sea Carrot. Moronyn arfor.

Admitted to T.B. on authority of Dillseyn. On cliffs of Gower, where in some years it is remarkably luxuriant, and assumes at first sight every appearance of being distinct from D. Carota. L.W.D.Mat. Pennard. Gutch. Phyt. 1842. p. I19. Frequent. Fontigary; Colhugh; Dunraven, \&c. J.S. and T.H.T. Oxwich; St. Donats. Ridl. Riverside, Ogmore. Miss B. Common near Langland; Pwlldu, \&c. $L$.

Notwithstanding all these records, the Editor, who has examined thousands of specimens of Daucus on the coast, from Penarth to Pennard, is still doubtful as to the occurrence of $D$. gummifer in the county. It is probable that the maritime form of D. Carota has been mistaken for it. It is even doubtful whether the individuals with convex fruiting umbels, which are by no means rare, belong to a distinct strain.

\section{Caucalis, Linn. 182 .}

730. arvensis, Huds. Field Hedge Parsley. Ridd.

About Swansea. Flower E Lees. Phyt. I843. p. 378. Aberdare. 
731. Anthriscus, Huds. Upright Hedge Parsley. Eulyn berllys. Common. Abundant. Native. Septal.

732. nodosa, Scop. Knotted Hedge Parsley. Cwlwm eulyn berllys. Local. Frequent. Native. Glareal, viatical, \&c.

Penarth ! Sully ! Swanbridge ! J.S. Penrhys Brook. Flor. Rhondda. Swansea. Flower \& Lees. Phyt. I843. Southerndown! frequent. Miss $B$. and $V$. Barry ! D. Hirwaun. W. Sully ! \&c. $H$. Llanmadoc. $L$. and $V$. Near Penmaen. $L$. Oxwich to Llanrhidian; Kenfig; S. Cornely. Ridd. Caswell Bay! Marcross ! Llantwit Major ! Leys ! and many other places.

\section{Araliaceæ.}

Hedera, Linn. 183.

733. Helix, Linn. Common Ivy. Eiddew. Eiddiorwg. Iorwg. Common. Abundant. Native. Sylvestral, rupestral, \&c.

\section{Cornaceæ.}

Cornus, Linn. I84.

735. sanguinea, Linn. Common Dogwood. Cwyros. (Glam. Cwyrwialen.) Local. Abundant. Native. Septal and sylvestral.

Frequent. Leckwith; Llandough; Penylan, \&c. J.S. Glyncornel. Flor. Rhondda. Too common for record on the calcareous rocks and soils; rare elsewhere. $E d$. Vale of Neath; never seen near Aberdare. $W$. Merthyr district. $E$. and $F$. 


\section{NOTE ON THE PREPARATION OF SECTION III.}

In the preparation of Section III. the numbers and names of the ninth edition of the London Catalogue have been used, notwithstanding the publication of the tenth edition. In this, novelty, and little else, has been sacrificed for uniformity.

The list of records has been considerably curtailed in this section, hy inserting them for those districts only where the species is rare or local. In many cases, too, one authority only for a locality is quoted;-in general, the oldest. All records are being preserved by the Hon. Secretaries, whether inserted or not, and will be available for future reference.

\section{Caprifoliaceæ.}

Adoxa, Linn. 185.

736. Moschatellina, Linn. Tuberous Moschatel. Anfri, Mwsglys. Local. Abundant. Native. Sylvestral.

Too common for the citation of its very numerous localities; but it is noteworthy that there are no records from the Valley of the Loughor and the Rhondda Valley. A typical humus plant.

Sambucus, Linn. 186.

737. nigra, Linn. Common Elder. Ysgawen, Ysgawlwyn cyffredin. Common. Abundant. Native. Sylvestral and septal.

One of the plants sacred in folk-lore. Bits in which the internodes were very short were cut as crosses for luck. T.H.T.

738. Ebulus, Linn. Danewort. Corysgawen, Creulys mawr, Ysgawen bendiged, Ysgawen Fair, Gwaed y gwyr.

Local. Frequent. Native (or Denizen). Viatical.

Court Herbert, near Neath. L.W.D.Mat. Cogan Pill! St. Athan! St. Brides Major! Maesteg Isaf, \&c. J.S. Newton Nottage, plentiful. R.E. \& F. Cundall, J. of B. 1902. p. 316. Merthyr District! very local. E. \& F. Hirwaun. IV. Llanmorlais, Swansea, Llandow, Monknash, and Aberdare. Ridd.

TRANS. CARD. NAT. SOC.—SUPPLEMENT. 


\section{Viburnum, Linn. I87.}

739. Opulus, Linn. Common Guelder-Rose. Gwifwrnwydd y gors, Corswigen.

Common. Abundant. Native. Sylvestral and septal.

Numerous localities are on record from all parts of the county; nevertheless the plant is, in many districts, local and infrequent.

740. Lantana, Linn. Wayfaring-tree.

Local. Abundant. Native. Sylvestral and septal.

Much commoner than No. 739 in the lowlands on calcareous soils, but apparently absent from the coal measures, and even from the Carboniferous limestone near Merthyr.

\section{Lonicera, Linn. 189.}

743. Periclymenum, Linn. Honeysuckle. Gwyddfid, Llaeth y geifr, Tethau'r gaseg.

Glam.- Melus y pia.

Common. Abundant. Native. Sylvestral and septal.

\section{Rubiaceæ.}

\section{Rubia, Linn. I 90.}

745. peregrina, Linn. IVild Madder. Gwreiddrudd gwyllt, Cochwraidd.

Local. Abundant. Native. Rupestral, septal, etc.

Frequent in the county. B.G. Cliffs and Gower coast! Gutch, Phyt. I842. p. 2 ro. Limestone cliffs and elsewhere in Gower! L.W.D.Mat. Frequent; Castell Coch woods! Penarth! Sully! Barry! etc. J.S. Mumbles! Nat. Hb. Southerndown! Miss B. Porthkerry! I. Lavernock to Sully! H. Llanmadoc. Ridd. St. Donats! Dunraven! Seldom found far from the coast.

\section{Galium, Linn. I9I.}

746. boreale, Linn. Cross-leaved Bedstraw.

This plant is recorded by $M r$. Riddelsdell from Craig-y-llyn on the authority of $A$. Ley. Other records, which are for localities at much lower levels are certainly incorrect; and it would be well if that of $M r$. Ley were confirmed, as it extends the area of distribution of the species in South Wales by adding Glamorgan to Brecon and Carmarthen.

747. Cruciata, Scop. Crosswort.

Common. Abundant. Native. Septal, etc.

Not very abundant as a rule, but distributed all over the county. 
748. verum, Linn. Yellow Bedstraw. Briwydd felen, Ceilion, Llys y cywer, Briger y twynau.

Common. Abundant. Native. Pascual, glareal, etc.

b. maritimum, DC. On the burrows of the coast and Stalling Down. Ridd.

750. Mollugo, Linn. Great Bedstraw.

Common. Abundant. Native. Septal, etc.

No records from the Merthyr district and the valley of the Loughor.

751. saxatile, Linn. Heath Bedstraw. Gwenwlydd lefn, Briwydd wen.

Common. Abundant. Native. Ericetal.

752. sylvestre, Poll. Mountain Bedstraw.

Rare. Abundant. Native. Rupestral?

Morlais Castle. Riddelsdell, Report of the Bot. Exch. Club. I904. p. 24 .

753. palustre, Linn. Marsh Bedstraw. Gwendon, Gwenwlydd y gors. Common. Abundant. Native. Paludal.

b. elongatum (Presl.) Oxwich! Crumlin Burrows, Neath, Llantwit Major, Peterston, Aberdare. Ridd.

c. Witheringii (Sm.) Swansea. Flower \& Lees. Phyt. I843. p.379. Neath, Aberdare. Ridd. Near Whitford Burrows!

754. uliginosum, Linn. Rough Marsh Bedstraw. Gwendon arw y migyn.

Local. Frequent. Native. Paludal.

Swansea. Flower \& Lees. Phyt. I843. p. 379. Taff Valley. J.S. Near Mardy Cemetery, and Bodringallt Farm. Fl.Rh. Hirwaun Common and Vale of Neath. W. Ewenny. Miss B. Porthkerry. I. Creigiau. D. Ystradowen. M.A.D. and V. Peterston. M.A.D. Llanishen. $V$. Rhossili ; Baglan to Aberafan; Mountain Ash and Aberdare. Ridd. Some of these records may refer to No. 753 and its varieties.

757. Aparine, Linn. Goosegrass. Cyngafan, Gwlydd y perthi, Llys yr hidl, Llai y perthi ; written "Lloy perthey" in "Gwynn book" -I7th century.

Common. Abundant. Native. Septal.

No. 758 is recorded as an alien by Riddelsdell from Swansea Docks, Port Talbot, Ystrądowen, Merthyr Dovan, and Aberdare. Other records for this species are Barry Island. Woods. Cyb. Brit. Vol. III. p. 450. Gileston, 1904. M.A.D. and V. 


\section{Asperula, Linn. 192.}

759. odorata, Linn. Sweet Woodruff. Llys yr eryr perarogl.

Local. Abundant. Native. Sylvestral.

Recorded from most lowland districts, where, however, it can scarcely be regarded as common. Rarer in the hill districts, records for which are:-Tylacoch, Maindy. Flor. Rhondda. Vale of Neath ! IV. Merthyr district. E. and F. Rhigos. Ridd.

761. cynanchica, Linn. Squinancy-wort.

Local. Abundant. Native. Pascual, glareal, etc.

Very abundant in Gower! Rare in the Eastern half of the County. Ed. Between Swansea and Neath. Phyt. I842. p. I 20. Near Southerndown! J.S., Miss B., D. and N. Kenfig! H. Barry Island! J.S. (2). S. Cornelau, Ogmore Down! Ridd.

\section{Sherardia, Linn. I93.}

763. arvensis, Linn. Field Madder. Sherardia glâs, Corwreiddrydd. Common. Abundant. Native. Glareal and agrestal.

\section{Valerianeæ.}

\section{Valeriana, Linn. 194.}

764. dioica, Linn. Small Marsh Valerian. Triaglog bychan y gors.

Local. Abundant. Native. Paludal.

Near Swansea. Flower \& Lees. Phyt. 1843. p. 379. Frequent. Llanedarn Road, Llanishen Water Works, etc. J.S. Frequent. Mardy, Pontrhondda, etc. Fl. Rhondda. Common near Hirwaun and Aberdare. $W$. Merthyr District. $E$. and $F$. Vales of Taff, Rhymney, Ely, and Neath; and moors of Gower. On hills to a considerable elevation. T.H.T. Ewenny. Miss B. Fairwater. I. Taffs Well! Castell Coch! H. St.-y-Nil, M.A.D. Llandough. J.E. Pencoed. V. Ystradowen. Ridd. Penarth ! Pendoylan ! Almost too common for detailed record.

765. Mikanii, Syme.

Local. Frequent. Native. Paludal.

Glyn Neath, Merthyr Tydfil, Cwm Selsig, and other places in the Rhondda Valley. Ridd. Graig-fawr, Treorchy! I898. U.C.Hb. Craig y Llyn! 1905.

766. sambucifolia, Willd. Great wild Valerian. Llys Cadwgan, Gwell na'r aur, Cynffon y capwllt.

Local. Abundant. Native. Paludal.

Near Swansea. Flower \& Lees. Phyt. I843. p. 379. North Road, St. Fagans, Llandaff, Pontcanna. J.S. Maindy, Penrhys, Tylacoch. Fl.Rhondda. Common about Hirwaun and Aberdare. W. Merthyr District. $E$. and $F$. Llancaiach. $V$. Garth ! $V$. and M.A.D. Radyr. M.A.D. Ewenny ! V. Peterston. M.A.D. 
Park Mill. L. Cwrt-yr-ala! $H$. Ogmore. D. Southerndown, Pendoylan, St. George. I. Twmpath Valley. Miss B. Nicholaston; Pwlldu; Whitford! Ystalyfera; Port Talbot; Cowbridge ! Ridd.

\section{Centranthus, DC. 195.}

768. ruber, DC. Red Valerian. Triaglog côch.

Local. Abundant. Denizen. Rupestral, glareal.

Wall of Friars Garden, Crockherbtown, 1830/ J.E. Penarth ! J.S. Beaupré. G.T. Coity. Miss B. Caswell Bay, Langland Bay. L. Tongwynlais; Southerndown. M.A.D. Treorchy. Fl.Rhondda. Aberdare; Southerndown; Newton; Swansea. Ridd. Flat Holme. Card. Nat. Soc. Trans. Vol. XXII. p. IIO.

\section{Valerianella, Moench. 196.}

770. olitoria, Poll. Common Lamb's-Lettuce. Diodwyth, Gwylaeth yr oen.

Local. Abundant. Native, Glareal, etc.

Common in hedge banks. N.S.G. Common. Penarth!

St. Fagans, Peterston, etc. J.S. Southerndown. Miss B., M.A.D. and $V$. Leys, Aberthaw, Fontigary, Porthkerry; Whitford and Hillend Burrows, Gower. Ed. Ogmore Castle, Porthcawl. Ridd.

772. carinata, Loisel.

Glyn Neath, but scarce. $W$. Aberpergwm. Ridd.

\section{3. rimosa, Bast.}

Two old records only. Fabians Bay. Gutch. Phyt. I842. p. I20. Norton. Woods. Phyt. 1850. p. 1057.

774. dentata, Poll. Gwylaeth yr oen deintiawg.

Local. Abundant. Native? Agrestal, etc.

The record by Gutch. Phyt. I842. p. I20; and in L.W.D.Mat. is doubtless to Glan-brân, near Llansamlet, notwithstanding the different spelling (Glanbrane, Glanbedue) and is assigned to E. Hawkins in each case. Southerndown. J.S. Park Mill. $H$. Sully ! N. Llanmadoc, Port Eynon! Oxwich; Kenfig; Welsh St. Donats; Caerphilly. Ridd. St. Andrews ! Creigiau !

\section{Dipsaceæ.}

\section{Dipsacus, Linn. 197.}

775. sylvestris, Huds. Wild Teasel. Teilai gwyllt, Llysiau'r cribau. Local. Abundant. Native. Septal, viatical, etc.

Banks of the Neath Canal; Fabians Bay. Gutch. Phyt. I842. p. I20. Lower Grangetown, Leckwith ! Penarth Road, etc. J.S. Penarth to Sully! plentiful. $H_{*}, V$, and M.A.D. Llantwit Major. J.S. (2). Southerndown. Miss B. Fairwater. $I$. Common in Gower. L. Pantyffynon, Gowerton; Port Talbot; Porthcawl; 
Merthyr Mawr; Ewenny. Ridd. So abundant on the calcareous soils of the lowlands that few definite records have been made. Absent from the hill districts; or very rare there.

776. pilosus, Linn. Small Teasel.

Rare. Scarce. Native? Sylvestral.

Llandough, Cowbridge! Rev. W. F. Evans. The plant is most abundant in a thicket of rhododendrons, and has probably been introduced with them. It is, however, thoroughly naturalised.

Scabiosa, Linn. 198.

777. Succisa, Linn. Devil's Bit Scabious. Clafrllys gwreidd-don, Bara'r Cythraul.

Common. Abundant. Native. Ericetal, pascual, \&c.

778. Columbaria, Linn. Small Scabious. Clafrllys bychan.

Local. Abundant. Native. Rupestral.

Mumbles ! Langland Bay ! Caswell Bay ! Pennard Castle ! Mewslade Bay! Ed. Langland Bay to Llanmadoc; S. Cornelau. Ridd.

The form on the rocks at Pennard Castle appears to be quite typical, hence Ball's record for the var. glabra in Bot. Gaz. must disappear.

779. arvensis, Linn. Field Scabious. Clafrllys, Clais, Penlas.

Common. Abundant. Native. Agrestal, etc.

\section{I. Compositæ.}

Eupatorium, Linn. 199.

781. cannabinum, Linn. Hemp-Agrimony. Byddon chwerw.

Common. Abundant. Native. Paludal, inundatal, etc.

Solidago, Linn. 200.

782. Virgaurea, Linn. Common Golden-rod. Eurwialen, Melyneuraidd.

Local. Abundant. Native. Sylvatical, rupestral, etc.

Found all over the county, in the lowlands as well as the uplands, but scarcely common.

b. cambrica (Huds.) Woods of Cwm Neath, frequent. Gutch. Phyt. 1842. p. I20. This record of Gutch, not of Flower, as given by J. Riddelsdell, needs confirmation.

Bellis, Linn. 20 r.

783. perennis, Linn. Daisy. Llygad y dydd, Briallu y dydd. Aspygan.

Common. Abundant. Native. Pascual. 
Aster, Linn. 202.

785. Tripolium, Linn. Sea Starwort. Serenllys y morfa, Llys tanewyn.

Local. Frequent. Native, Littoral.

Occurs all round the coast, from the Rhymney to the Loughor, on salt muds, but only near the high-water mark. The non-radiate form occurs on the Rhymney, Taff, and Ely; and at Barry.

There are no trustworthy records for No. 786. Storrie's records may have been based on casual plants.

\section{Erigeron, Linn. 203.}

787. canadense, Linn. Canadian Fleabane.

Local. Frequent. Denizen and Alien. Viatical, etc.

On sandy ground below the bridge at Neath, Glam., to all appearance perfectly wild. $M r$. Middleton. Eng. Fl. Smith. Vol. III. p. 422 .

Waste ground, Cardiff ! J.S. Pentyrch. J.S. (2). Taffs Well. M.A.D. Kenfig ! $H$. Cogan ! Cathays Park. V. Port Talbot. Ridd. Grangetown! Barry! This plant offers a striking illustration of the impossibility of determining the status of a species, except by historical methods. It occurs on the moist bottoms amongst the sand dunes at Kenfig, as wild as any other member of our Flora.

788. acre, Linn. Blue Fleabane. Amrhydllwyd rhuddlas.

Local. Frequent. Native. Glareal, etc.

Near Swansea. Gutch. Phyt. 1842. p. 120. Nottage! J.S. Hirwaun and Aberdare. $W$. Morlais Castle. E. and F. Penllergare. G.T. Cefn On; Barry Island ! J.S. (2). Pyle to Porthcawl! $H$. Taffs Well! H. and M.A.D. Newton Burrows! Pentyrch slag tips! V. Penmaen, Gower. Mrs. Nicholl. Kenfig Burrows! N. Caswell Bay. L. Crumlin Burrows; Ystalyfera ; Port Talbot; S. Cornelau. Ridd. Oxwich! Llansanwr!

Filago, Linn. 204.

790. germanica, Linn. Common Cudweed. Edafeddog lwyd, Llys y gynddaredd, Llwyd y ffordd, Pen llwyd.

Local. Frequent. Native. Glareal, etc.

Frequent. E. Moors, Grangetown, Penarth. J.S. [Probably ballast plants. $-E d$.] Frequent. Pontrhondda. Fl. Rhondda. Southerndown! Miss B., V. and N. Park Mill! L. Swansea. G.T. Penarth. $H$. Kenfig! Taffs Well! Cwrt-yr-Ala! Mead Moor! Gower. Ed. Three Cliffs Bay to Llanmadoc ; Port Talbot ; Porthcawl ; Cowbridge; Caerphilly. Ridd.

793. minima, Fr. Slender Cudweed. Edafeddog leiaf, Digoll lwyd. Local. Frequent. Native. Glareal, ericetal, etc.

Nottage. R.E. and F. Cundall. J. of B. I902. p. 3 I 6. Gower. E. F. Linton. J. of B. 1892, p. 296. Merthyr District. $E$. and $F$. Coed-pen-main; Abertridwr; Pentyrch slag tips ! 
J.S. (2). Kenfig! $H$. and $V$. Melingriffith Works, $V$. Ewenny Down! Ogmore Down! Ed. Penard Burrows ; Frog Moor ; Ystalyfera; Port Talbot; S. Cornelau; Aberdare. Ridd. Cefn Bryn!

\section{Antennaria, Gaertn. 205.}

795. dioica, R.Br. Mountain Evorlasting. Edafecklog fynyclelig, Edafeddog ysgaredig.

Rare. Scarce. Native. Ericetal, pascual, etc.

On the hills above Pontneddfechan. B.G. Rhondda Valley, near Pentre; Glyn Ogwr. J.S. Morlais Castle, spec. in U.C.Hb. ; mountains between Merthyr and Aberdare. T.H.T.

\section{Anaphalis, DC. 206.}

796. margaritacea, Benth. and Hook. fil. American cudweed.

Local. Abundant. Native or Denizen. Rupestral, etc.

"On the banks of Rymny River for the space of at least twelve miles." Mr. Lhwyd. Ray. Syn. Ed. III. I724. p. I82, Caerphilly and Quakers Yard; near Neath Abbey. E. Forster, jumr. Other places near Neath. Ed. Hawkins, junv., B.G. Side of R. Rhymney, I $\frac{1}{2}$ miles from Caerphilly Castle, Glam., I808. Mr. Middleton, A.B. Swansea, 1820. Rev. J Dalton. Spec. in Herb. York Phil. Soc. - a record due to $A . B$. Near Clydach, on the roadside between Wychtree Bridge and Neath Abbey. Gutch. Phyt. I842. Kenfig Burrows, about a mile from houses. Marshall \& Shoolbred, $J$. of $B$. 1902. p. 248. Rhymney Valley from Pwllypant downwards, Llanishen, etc, J.S. Rhondda Valley. Fl. Rhondda. Aberdare; Hirwaun. $W$. Neath Valley. G.T. Merthyr district. E. and F. Kenfig. $H$. Largely increased of late years owing to railway works, and now found in most of the valleys as well as on the sand-dunes. T.H.T. Gowerton; Pantyffynon; Llangyfelach; Ystalyfera, spreading to inaccessible cliffs; Graig Fawr, Treorky! at I,500 feet. Ridd. Near Dinas Rock, Pontneddfechan. Woods. Phyt. I850. This is possibly a Breconshire locality, but serves to show the N. and W. extension of the area of this species at this date.

The status of this species is not yet satisfactorily fixed, and cannot be until its history has been thoroughly re-investigated. The position of alien or denizen to which it is generally consigned appears to be due to Clusius, a botanist of the 16 th century. It is noteworthy that nearly 200 years ago it was observed to extend along the banks of the Rhymney for 12 miles. The habitat of the species is likewise quite misunderstood. In Bab. Man. Ed. 9, this is given as "Moist meadows, rare. Established by rivers, etc." The plant is found all over Glamorgan, with the exception of the peninsula of Gower, and the heavy clay land of the Vale of Glamorgan; and ascends from the lowest levels to a height of $I, 500$ feet. It is most at home on broken stony ground, which is well drained and dry in summer; and where, owing to the comparative infertility of the soil, it runs little danger of being overgrown and smothered by taller plants. Its original habitat appears to have been the gravels left high and dry by the heavy floods 
of the Rhymney; for there were neither railway embankments, coal tips, nor large quarries in Glamorgan in 1724. At the present time, however, it is chiefly found on " made " ground. It is quite incapable of growing in " moist meadows" amongst grass. Once the fertility of the habitat rises to the point necessary to support a luxuriant crop of grass, the fate of the cudweeds, "hardy perennials" though they may be, is sealed. The plant is strictly adapted to the "open formation"-hence its occurrence on sand-dunes, river gravels, railway embankments, mountain screes, coal tips, slag hills, and even "bare rock" is readily understood.

\section{Gnaphalium, Linn. 207.}

797. uliginosum, Linn. Marsh Cudweed. Penddu, Edafeddog benddu.

Common. Abundant. Native. Inundatal, agrestal.

799. sylvaticum, Linn. Upright Cudweed. Edafeddog uniawnsyth y goedwig.

Rare. Scarce. Native. Ericetal, pascual.

Drymma and Glan-brân; Mynydd March-Hywel. Gutch. Phyt. 1842. Aberdare and Cynon Valley. J.S. Near Onllwyn. T.H.T.

\section{Inula, Linn. 208 .}

802. Helenium, Linn. Elecampane, Marchalan, Llwyglys. Clafrlys mawr.

Local. Frequent. Native? Inundatal, septal, etc.

Port Eynon! B.G. Horton! Penllergare, Pontneddfechan, Glan-brân and Cwm Crumlyn. Gutch. Phyt. I842. Penarth, Michaelstone-le-pit! Leckwith ! Bridgend! Maesteg. J.S. Dinas Powis! Barry! D. Porthkerry! J.S. (2). Fairwood Common ; Penmaen ! Nicholaston! L. Cogan. J.E. The Merch, Dinas Powis! Mrs. Holme Russell. Leckwith! Miss Corbett. Sully. Woods. Phyt. I850. p. I060. Nottage. R.E. and F. Cundall. $J$. of $B$. I902. p. 3I6. Gowerton. Ridd. Nash ! Marcross ! Cheriton! Oxwich ! A plant of the lowlands, now often indistinguishable from the undoubted natives.

803. Conyza, DC. Ploughman's Spikenard. Meddyg Mair, Codowydd, Meddyg y bugail.

Local. Abundant. Native. Septal, rupestral, glareal, etc.

Too frequent on the light soils of the Vale of Glamorgan for detailed citation of the habitats. Rare in the hill districts. Aberdare. $W$. and Ridd.

805. crithmoides, Linn. Golden Samphire. Cedowys sugawl, Sampier y. geifr.

Local. Abundant. Native. Littoral.

Absent from coast E. of Southerndown. Ed. Southerndown ! I., Miss B., V. and M.A.D. Mumbles to Rhossili. Ed. and many correspondents. Coast near Llangenydd! T.H.T. Burry Holms ! 


\section{Pulicaria, Gaertn. 209.}

8o6. dysenterica, Gartn. Greater Fleabane. Cedowys cyffredin. Common. Abundant. Native. Inundatal, pascual, etc.

Storrie's record for No. 807 remains unconfirmed and is therefore excluded.

\section{Bidens, Linn. 211.}

81 o. cernua, Linn. Nodding Bur-Marygold. Graban ogwydd.

Local. Frequent. Native. Paludal.

Singleton, Swansea. Gutch. Phyt. I842. St. Fagans ; Coedriglan. J.S. Ewenny. Miss B. and V. Bishopston Valley ! L. Rhossili. D. Upper Boat, Taff Valley; sp. in U.C.Hb. Mr. Chapman. Taffs Well! 1905. Oxwich! 1908, scarce.

8I I. tripartita, Linn. Tripartite Bur-Marygold. Graban eir-rhan.

Local. Abundant. Native. Paludal.

Near Neath Canal. Gutch. Phyt. I842. St. Fagans; Coedriglan. J.S. Hirwaun; Aberdare. $W$. Merthyr ! E. and $F$. Melingriffith Works. V. East Moors; Dumballs pond. J.S. (2). Radyr. I. and M.A.D. Ewenny! I. and Miss B. Fairwood Common. Mrs. Nicholl. Rhossili. D. Mynydd Garngoch; Port Talbot; Ystradowen; Peterston; Penrhiwceiber. Ridd. Horton ! Llanddewi! Llangenydd! Burry ! Burry Green ! Cefn Bryn ! Oxwich ! Penrice! Mead Moor ! Llanrhidian and other places in Gower! Taffs Well! Leckwith! Llandough! Dinas Powis! Porthcawl !

\section{Achillea, Linn. 213.}

813. Millefolium, Linn. Yarrow. Gwilffrai, Milddail, Llys y gwaedlif.

Common. Abundant. Native. Pascual, etc.

814. Ptarmica, Linn. Sneeze-wort Yarrow. Ystrewlys, Dystrewlys, Tafod yr wydd.

Common. Abundant. Native. Pratal, pascual, etc.

\section{Anthemis, Mich. 255 .}

817. Cotula, Linn. Stinking Mayweed. Milwydd, neu Camri y cwn. Local. Abundant. Native. Agrestal, viatical.

Often very abundant in the lowlands from Penarth to Rhossili. Rare on the coal measures apparently; the only localities on record being:-Llantrisant. J.S. Penllergare; Graigafan; Aberdare. Ridd.

8 I 8. arvensis, Linn. Corn Chamomile.

An alien, found about the local docks. Cardiff. J.S. Barry ! $V$. Port Talbot. Ridd. Swansea. Gutch. Phyt. I842. Also at Aberdare. Ridd. Merthyr. E. and F. 
8rg. nobilis, Linn. Common Chamomile. Milwydd, neu Camri cyffredin.

Local. Frequent. Native? Pascual.

As an alien about Penrice. L.W.D.Mat. About Cardiff Docks. $J$.S. and $V$. Southerndown. Miss B. Mynydd Garngoch ; St. Brides Major. Ridd. Reynoldstone ! U.C.Hb. Pitton Green ! Oxwich Green !

\section{Chrysanthemum, Linn. 216.}

820. segetum, Linn. Corn Marigold. Gold yr yd, Golt, neu Aban.

Local. Abundant. Colonist. Agrestal.

Ballast near Swansea. Gutch. Phyt. 1842. Penrhys Farm. Fl. Rhondda. Hirwaun; Aberdare; Vale of Neath. W. Merthyr. $E$. and $F$. Radyr. J.E. Cowbridge. I. Southerndown. Miss $B$. Gower. L. Kenfig; Llancarvan. T.H.T. Vale of Neath. H.

82I. Leucanthemum, Linn. Great White Ox-eye. Aspygan, Sensigl, Llygad y dydd mawr.

Common. Abundant. Native. Pascual, etc.

No. 822 is not infrequent as a casual and has been reported by five correspondents.

\section{Matricaria, Linn, 217.}

823. inodora, Linn. Scentless Mayweed, Ffenigl y cwn.

Common. Abundant. Native. Agrestal, viatical, etc.

As to the maritime varieties of this plant, including No. 824 , I have not so far, although I have examined the plants of the Gower coast, seen any reason for regarding them as more than "states" of one species. The position of the forms has never been tested, so far as I am aware, by a set of comparative cultures. The plants of the limestone cliffs certainly live for more than two years as a rule, but this may be due to the mild climate and perfect drainage. Mr. A. Bennett, to whom I submitted a small specimen from the Paviland cliffs, bearing flowers in the third year, and labelled $M$. inodora $b$. salina, says, "If so, a very poor specimen."

825. Chamomilla, Linn. Wild Chamomile. Amranwen cyffredin.

Local. Abundant. Status doubtful, generally Colonist or Alien. Viatical, agrestal, etc.

Blaenrhondda, on ballast. $F l$. Rhondda. Casual in Gower. E. F. Linton. J. of B. 1892. p. 296. Aberdare; Hirwaun. IW. Llandaff. J.E. Sully. $V$. St. Hilary. G.T. Newton Nottage. Miss B. Gower. L. Gowerton; Penllergare; Port Talbot; Barry; Roath; Pengam Moors. Ridd. About Cardiff, Penarth and Barry Docks ! Cogan ! Sully ! Lavernock ! Dinas Powis ! St. Fagans ! Marcross!

suaveolens, Buchenau. (discoidea, DC.) Numerous records for this alien from all districts except Gower and the Valley of the Loughor. Appears often as if introduced with seed used for feeding fowls. 
Tanacetum, Linn. 219.

827. vulgare, Linn. Common Tansy. Tanclys, Wroith, Gystlys cyffredin.

Local. Abundant. Native? Viatical, etc.

Perfectly naturalised, if not native, in many places. Habitats too numerous for separate record.

\section{Artemisia, Linn. 220.}

828. Absinthium, Linn. Common Wormwood. Chwerwyn, neu Wermod lwyd.

Local. Abundant. Denizen or Native (few places). Viatical.

Swansea. Gutch. Phyt. I842. p. I21. St. Athans! Flemingston! J.S. Blaenrhondda ; Clydach Vale. Fl. Rhondda. Porthcawl. R.E. and F. Cundall. J. of B. 1902. p. 316. Canton. Nat.Hb. Hirwaun and Aberdare as casual. $W$. Southerndown ! Merthyr Mawr. Miss B. Gower ! L. Llancarfan; Three Crosses. T.H.T. Llanrhidian; Llanmadoc; Pengam Moors. Ridd. Llantwit Major ! Marcross! very abundant. St. Donats !

829. vulgaris, Linn. Mugwort. Bydiawg lwyd, Canwraidd lwyd, Llwydlys.

Common. Abundant. Native. Septal, viatical, etc.

831. maritima, Linn. Sea Wormwood. Chwerwlys, neu Wermod arfor syth flodeuog.

Local. Abundant. Native. Littoral.

This plant grows around the estuaries of all our chief rivers from the Rhymney to the Loughor, generally just above or near the point reached by the highest tides. The erect form has been recorded from Swansea and Cardiff.

\section{Tussilago, Linn. 221.}

832. Farfara, Linn. Common Coltsfoot. Alan bychan, Pesychlys, Carn yr ebol, Llun Troed yr ebol.

Common. Abundant. Native. Inundatal, viatical, agrestal, etc.

\section{Petasites, Linn. 222.}

833. fragrans, Presl. Winter Heliotrope.

Local. Abundant. Denizen. Viatical.

Cardiff ! Penarth ! Llandough ! St. Andrews, Dimlands, Llantwit Major, etc. J.S. Coedriglan. G.T. Swansea ; Nicholaston ; Oxwich; Langland Bay; Mumbles Road; Port Talbot; Porthcawl. Ridd.

834. officinalis, Moench. Common Butter-bur. Alan mawr, Dail y tryfan.

Local. Abundant. Native. Inundatal, etc.

Abundant on the river gravels and about the banks of the Rhymney, Taff, and Ely ! J.S. Hirwaun; Aberdare! W. Mer- 
thyr ! E. and F. Park Mill stream ! L. and T.H.T. Waycock River ! $D$. Oxwich; Penllergare; banks of Loughor; Neath ; Llantwit Major; Ridd. River Thaw! Probably along every river in the County.

\section{Senecio, Linn. 224.}

838. vulgaris, Linn. Common Groundsel. Grëulys, Garnedd felen, neu Penfelen fenyw.

Common. Abundant. Native. Agrestal, viatical, etc.

This is an aggregate species, and includes in the immediate neighbourhood of Cardiff four distinct forms and their hybrids. The radiate form of the Channel Islands and at least one continental form are distinct from these.

About the year I89I. I began to examine the striking radiate type which is so abundant around Cardiff and Penarth, and in January, I 894 , Dr. C. T. Vachell directed the attention of the members of the Cardiff Naturalists' Society to it. A specimen was sent to Kew and Mr. Hemsley reported upon it as follows :- "I cannot make anything of this, but vulgaris b. radiatus."

The occurrence of two distinct radiate forms in my own garden at Penarth and the discovery of a dwarf form growing amongst normal individuals in Cathays Park, combined with the necessity for distinguishing these for record in the Flora, induced me, ten years later, to submit all the forms to a process of testing by means of experimental "pedigree" cultures. The experiments commenced in September, 1905, and, partly owing to the discovery of additional forms, are still in progress.

Confining our attention to Glamorgan plants, I find it necessary, as one result of these experiments, to recognise the following segregates:-

a. præcox, Trow. Found at Cathays Park, Cardiff! and in Penarth !

b. erectus, Trow. Apparently abundant in Glamorgan.

c. erectus, var. radiatus, Trow. Found at Cardiff! Penarth ! and Barry! and according to Riddelsdell, at Oystermouth and Port Talbot.

d. multicaulis, Trow. Found at the Hayes! Swanbridge! and Barry Dock! tion (6).

Hybrids of these probably occur in every possible combina-

The following have been obtained experimentally, and sometimes by each of the two possible ways :-

precox $\times$ erectus, var. radiatus. In this case, evectus, var. radiatus is dominant.

evectus $x$ evectus, var, radiatus.

multicaulis $\times$ evectus, var, radiatus. 
A full account of the experiments is reserved until the work has been completed. The more salient characters serving to define the segregates may, however, be profitably given here.

(a) pracox, Trow. This form, when young, has a somewhat zig-zag stem, with few, but very long internodes; the leaves are nearly plane and not deeply pinnatifid as in the other types; the main axis, too, is soon overtopped, and even pushed aside by a lateral branch; and the capitula are small and slender. The time from the date of sowing to the production of ripe seeds, a time which may well be called a 'generation,' is 72 days. (3oth March, I908, to Ioth June, 1908.) This form exhibits definite adaptations in all its parts to secure rapid development and early maturity.

(b) evectus, Trow. This form has many rather short and stout internodes, and a straight erect stem. The leaves are deeply pinnatifid, indeed pinnatisect, somewhat yellow green in colour and strikingly pectinate when half developed, especially near the apex of the stem. The capitula are of medium size. A generation equals 83 days. (3oth March, I908, to 2 rst June, I908.)

(c) evectus, var. radiatus, Trow. This is the radiate form of the preceding type. I cannot, indeed, distinguish the one from the other, at any time up to the moment when the flowers begin to appear, when, of course, the difference becomes very obvious. The ray florets are sometimes very long, and are revolute only at night, in bad weather, or in old flowers, - the number per capitulum ranging from 8 to I3. The ray florets do not correspond to the figure in Sowerby's Eng. Bot. Ed. III., which is no doubt drawn from a Channel Island specimen. A generation equals 83 days.

(d) multicaulis, Trow. This is readily recognisable by the following characters:-(I) the dark green colour with a greyish surface tone ; (2) leaves like those of erectus, but longer; (3) large capitula-broad and rather short; (4) the soft yellow colour of the disc florets; (5) the browning of the disc after pollination; (6) the short basal internodes (Io or more) and hence the biennial appearance when young (leaf rosette) and the production of numcrous stcms (multicaulis) springing from the base later; (7) the long internodes of the upper branches, giving an open character to the inflorescence; (8) a long conspicuous bract on the pedicel of the terminal capitulum; (9) long bracts subtending the upper branches; (IO) the tendency to keep the capitula nearly erect during the ripening of the fruit; and (II) the large cotyledons of the seedlings. A generation equals 90 days. (30th March, 1908, to 28th June, I9n8.)

Upon the whole, precox may be described in the gardener's terminology as early, multicaulis as late, and evectus as intermediate.

The radiate form with short, sometimes almost erect, and distinctly toothed rays is the hybrid of erectus, var. radiatus with one of the other forms, generally evectus. It has been noted at Cardiff ! Penarth! and Barry!

These four segregates maintain their distinctive characters when grown side by side under the same conditions and protected from cross-pollination. 
The hybrid segregates according to Mendel's law. In one test culture- - of seeds taken from a single individual of the hybrid evectus $\times$ evectus, var. radiatus-which comprised 449 plants, the progeny proved to be as follows :-

$$
\begin{array}{ll}
\text { erectus individuals. . . . . . } & =109 \\
\text { erectus, var. radiatus individuals } & =114 \\
\text { hybrids, like the parent plant } \ldots & =226
\end{array}
$$

The numbers required by Mendel's law for a culture of 448 plants would be II 2 , I 2 , and 224 .

The hybrid evectus $\times$ squalidus appears to occur, indeed I have one living specimen collected in the Cathays Park which can scarcely be anything else. I have failed, however, to obtain this hybrid experimentally. Six different experiments, extending over two years and involving the raising of hundreds of plants, produced no result.

It may be added that many, indeed most, of the forms of groundsel subjected to experiment have proved to be "states" which lose their special character even in the first generation. $E d$.

839. sylvaticus, Linn. Mountain Groundsel. Grëulys, neu Penfelen fynyddawl.

Local. Abundant. Native. Glareal, septal, etc.

Many records have been rejected as too doubtful for insertion. Storrie's notes show that he mixed up several species of Senecio. River gravels of the Ogmore. Miss B. Southgate, Gower. L. Leckwith? M.A.D. Greenhill. V. Salthouse Point; Rhossili; Llangenydd ; Penyrheol ; Porthcawl; Aberdare ; Cwmaman; Ystradowen. Ridd. Pontypridd ! Mumbles to Caswell Bay ! Horton! Port Eynon! Pitton! Penrice! Oxwich ! Burry Green ! and other places in Gower.

The viscid form of this species is proved by my experiments to be sylvaticus $\times$ viscosus.

This hybrid has not yet been observed to occur wild in Glamorgan, though I have collected the two parents in the same quarry.

840. viscosus, Linn. Stinking Groundsel.

Local, Abundant. Native? Viatical, etc,

Near Swansea. E. Forster, jun., B.G. Crymlyn Burrows ; and between Marble Mill and Norton. L.W.D.Mat. Cwm Afan. Mr. Motley. Porthcawl sandhills. R.E. and F. Cundall. J. of B. 1902. Storrie's records refer to No. 838 , evectus, var. radiatus, Trow. Pontygwaith? Fl. Rhondda. Hirwaun and Aberdare. W. Merthyr District. E. and F. Peterston. M.A.D. Ely. $V$. Ystalyfera; Port Talbot; Pyle; Barry; Porth. Ridd. Pontypridd! Taffs Well !

841. squalidus, Linn. Inelegant Ragwort.

Local. Abundant. Alien or Denizen. Viatical.

This plant is thoroughly established in the Cardiff area, and may possibly have been introduced from Swindon, where it is likewise abundant. Its centre or centres of distribution appear to be the three 
railway stations (embankments), and the ruins of the White Friars. Ed. Penhill. I. Penarth! G.T. Riverside! H. Llandaff; Cogan ; Cardiff Castle. M.A.D. Merthyr District ? E. and F. Port Talbot. Ridd. I fear that many of the records for the hybrid $\times$ vulgaris have no relation to this species. They are mostly based on plants of erectus, var. radiatus.

842. erucifolius, Linn. Hoary Ragwort. Penfelen, neu Grënlys lledlwyd culddail.

Local. Abundant. Native. Ericetal, etc.

So common in the Vale of Glamorgan on the Lias clays from Penarth to Southerndown that every parish might probably be recorded. Apparently very rare or entirely absent elsewhere. Swansea. Flower and Lees. Phyt. I843. p. 379. Port Talbot. Ridd.

843. Jacobaea, Linn. Common Ragwort. Grëulys, neu Carnedd felen wrryw, Llys y gingroen.

Common. Abundant. Native. Glareal, pascual, etc.

A dominant type on the sand-dunes. A single specimen of a rayless form noted in 1908 near Penarth.

844. aquaticus, Huds. Marsh Ragwort. Grëulys, neu Penfelen y gors. Common. Abundant. Native. Inundatal, paludal.

\section{Carlina, Linn. 225 .}

850. vulgaris, Linn. Carline Thistle. Ellast cyffredin, Ysgallen ddrainwen.

Local. Abundant. Native. Glareal, pascual, littoral.

Chiefly on the coast, but recorded from all parts of the County except the valley of the Loughor.

\section{Arctium, Linn. 226.}

Nos. $851,852,853$ and 854 constitute an aggregate species;-

Arctium Lappa, Linn. Greater Burdock. Cedowrach, Bawmwcci, Cacamwcci, Ciawg, Cribau'r bleiddiau, Cyngaf mawr.

Common. Abundant. Native. Viatical, septal, etc.

The segregates are still perhaps somewhat ill-defined.

\section{1. majus, Bernh.}

Cadoxton and Sully Moors ! ! Dinas Powis ! Cwrt-yr-Ala ! Leckwith ! Cheriton! Llangenydd! Llandough, Cowbridge ! Ed. Nicholaston; Park Mill; Oxwich; St. Brides Major; Wenvoe. Ridd. Penlline! Pendoylan!

\section{2. nemorosum, Lej. = A. Newbouldii, Ar. Benn.}

Aberdare. Ridd. Cheriton! Penrice! The last two may possibly refer to aberrant forms of No. 854 which is very variable. These plants certainly had the heads "agglomerated and almost sessile at the apex of the principal stems." 
853. minus, Bernh.

St. Brides, Southerndown ! ! Leckwith ! Sully and Cadoxton Moors! Llandough! Cheriton! Horton! Penarth! Ed. Oxwich ; Langland Bay; Aberdylais ; Neddfechan Glen ; Monknash ; Cowbridge; Aberdare; Garth Wood. Ridd.

854. intermedium, Lange. = nemorosum, Lej. of continental authors and Lond. Cat. Ed. IO.

This is a very variable plant, and according to Mr. Beeby, $J$. of $B$. I908. p. 382 , is an aggregate consisting of majus $\times$ minus hybrids and a variety of mimus. This accounts very satisfactorily for its variability and for its occurrence in Glamorgan, in the immediate neighbourhood of the two parents. Leckwith ! ! Llansanwr! Llandough, Cowbridge! Taffs Well to Caerphilly! Leys to Llantwit Major ! Pennard ! Ed. Park Mill ; Three Cliffs Bay ; Nicholaston; Wenvoe; Aberdare. Ridd. Penlline!

\section{Carduus, Linn. 227.}

855. pycnocephalus, Linn. Slender-flowered Thistle. Ysgallen mânflodeuog.

Local. Abundant. Native. Viatical, littoral.

Extends all round the coast. No records for inland localities.

856. nutans, Linn. Musk-Thistle. Ysgallen ogwydd.

Local. Abundant. Native. Pascual, viatical, etc.

Quite common near the coast and for some distance inland. Furthest points inland are:-Llandaff, J.S. Cefn On. Ridd. Cwrtyr-Ala ! St. Hilary ! St.-y-Nil !

857. crispus, Linn. Welted Thistle. Ysgallen grych.

Local. Abundant. Native. Viatical, etc.

Most of the records must be treated as for the aggregate since our correspondents do not clearly distinguish whether they refer to acanthoides (Lim.) as a synonym for the species, following Bentham, or as the name of a segregate, following the Lond. Cat. and Bab. Man. All my own records are for the type. I have not yet detected the variety c. acanthoides (Linn.).

Swansea. L.W.D.Mat. Cardiff ! Penarth! Dinas Powis, etc. J.S. Penrhys. Fl. Rhondda. Gower. A.G. More. J. of B. I884. p. 46. Southerndown ! Miss $B$. St. Fagans! $I$. Sully. $H$. Gower. L. Peterston. M.A.D. and V. Kenfig Hill, T.H.T. Llandough! Aberthaw! Llantwit Major! Marcross ! St. Donats ! Cwm Alun! Park Mill! Ed. Llanrhidian; Bridgend. Ridd.

c. acanthoides (Linn.) Park Mill; M. Dyfan; Monknash ; Barry; Llantwit Major. Ridd.

$\times$ nutans. Llantwit Major. Ridd.

\section{Cnicus, Linn. 228.}

858. Ianceolatus, Willd. Spear-Thistle. March Ysgallen.

Common. Abundant. Native. Viatical, pascual. 
859. eriophorus, Roth. Woolly-headed Thistle.

Local. Abundant. Native. Viatical, pascual.

Very wide spread and often very abundant on the liassic clays of the Vale of Glamorgan. Newton Nottage; between Neath and Pyle. L.W.D.Mat.

860. palustris, Willd. Marsh-Thistle, Ysgallen y gors.

Common. Abundant. Native. Pratal, inundatal, etc.

Often with white flowers.

861. tuberosus, Roth. Tuberous Thistle.

Rare. Abundant. Native. Pascual, littoral.

In some respects the most interesting plant in Glamorgan. Between St. Donats and Dunraven. T. Westcombe. Phyt. I 844. p. 780. Referred, however, by T. B. Flower and H. C. Watson to C. Woodwardii. Phyt. I852. p. 519. Riddelsdell questioned the accuracy of this conclusion, and suggested it might be a form of C. acaulis. Bot. Exch. Club Report. 1904. p. 25. In his Flora of Glam. p.39, however, he says "apparently" $C$. tuberosus; and in Bot. Exch. Chub Report, 1907, definitely C. tuberosus. Not having seen a specimen of the Wiltshire plant, I sent fresh material to Mr. A. Bennett, in 1905, who reported "Not C. tuberosus," but have "little doubt" it is Watson's C. Woodwardii. It does not accord at all well, however, with a specimen of $C$. Woodwardii in the British Museum.

It still remains necessary to consult type plants of these two forms, but in the meantime, the balance of evidence is in favour of the conclusion that our plant is $C$. tuberosus and not $C$. Woodwardii. I transplanted a specimen into my garden at Penarth in I905, the soil being similar to that of its native habitat. I collected seeds from Nash plants in 1905 and 1906, and raised plants in 1906 and 1907. These proved to be perennials uniformly true to type, flowering in the second and subsequent year. C. acaulis may flower in the first year. I grew the reputed parents on each side of the colonies of $C$. tuberosus, only to be astonished that any one should imagine that these plants could be related to each other in this manner. Moreover, not only does $C$. tuberosus grow in its native habitat at a distance from $C$. pratensis-as Riddelsdell has already stated-but the flowering period of $C$. pratensis is over long before that of C. acaulis begins, so that I have not been able to secure pollen to attempt to make the cross artificially. The main root is distinctly tuberous (like a stout carrot) in the first and especially in the second year, and the primary stem terminates its existence in the second year by producing the main inflorescence. After the seeds have been ripened, the primary stem dies down, and the buds axillary to the basal leaves grow out to form short ascending branches. New roots form on the under side of these branches, and develop into smaller fusiform tubers, the old one becoming hollow and soon reduced to a skeleton framework of vascular bundles. In consequence of similar growths year after year, the old stems appear to creep a little, but they never develop long rhizomes such as are characteristic of 
C. pratensis. If allowed to seed, young plants spring up around the old ones in abundance. Great quantities of seed are set. In 1908 I saved the seeds separately of 35 heads, taken from two and three year old specimens and from one old plant, six or more years old. The seeds-all sound-were counted separately for each head, the number ranging from $3 I$ to 208 , with a total of 4,528 seeds, or an average of I29. It is certain, then, that our plant breeds true, sets seeds freely which germinate well, and furnishes no evidence of hybrid origin.

862. pratensis, Willd. Meadow-Thistle.

Local. Abundant. Native. Uliginal.

Although local, the localities recorded are very numerous and scattered all over the county. Grows in a soil black with humus. Rather infrequent in the Vale of Glamorgan, for which alone the records are given. Pendoylan! I. Creigiau. D. Peterston. M.A.D. Llandough. J.E. Llanishen ! Lisvane ! Pencoed. J.S. Pyle; Porthcawl; Cadoxton. Ridd. Sully Moors ! Welsh St. Donats ! Penarth !

865. acaulis, Willd. Dwarf Thistle.

Local. Abundant. Native. Pascual.

Absent apparently from the coal measures, and more frequent in the lowlands than would appear from the scanty records.

Briton Ferry. Gutch. Phyt. I 842, p. I2I. Barry Island ! and Sully. J.S. Southerndown. Miss B., V. and N. Pendoylan. I. Cefn On ! V. Lavernock! Dinas Powis ! Leys to Llantwit Major! Ed. Paviland; Barry to Aberthaw; Nash Point. Ridd.

The caulescent state is simply due to luxuriant growth. Many of the plants of a colony in my garden had branched stems 9 inches high, although the seeds were obtained from typical acaulis, growing on the sterile soil of the Cross Common, Dinas Powis.

866. arvensis, Hoffm. Creeping Thistle. Ysgallen gyffredin yr âr. Common. Abundant. Native. Agrestal, viatical, etc.

b. mitis, Koch. Port Talbot; Cwmdare. Ridd. Penlline! U.C.Hb.

d. setosus (Bess.) Taffs Well. sp. U.C.Hb!! Mr. Chapman.

\section{Onopordon, Linn. 229.}

867. Acanthium, Linn. Scotch Thistle. Ysgallen gottymmog. Local. Scarce. Alien? Viatical.

Southerndown, frequent. Miss B. Penllergare. G.T. Aberthaw. M.A.D. and $V$. Near Sully Island, growing vigorously, I902. T.H.T. Penarth ! H. Llantwit Major, very rare, but looking quite native. Ridd.

Most correspondents record it as an escape or casual, and such it may well be regarded in all cases. Thistle seed may be carried a considerable distance under favourable conditions. 
No. 868 has been recorded from E. Moors, Dinas Powis, Newton Nottage, Ilston, Cowbridge, Aberthaw, Aberafan, and Barry Island, always as a typical alien.

\section{Serratula, Linn, 232.}

870. tinctoria, Linn. Common Saw-wort. Dant y pysgoden, Lliflys cyffredin.

Common. Abundant. Native. Sylvestral, etc.

No record yet from the valley of the Afan.

b. monticola (Boreau.) Mynydd Garngoch; Fedwhir, near Aberdare. Ridd.

\section{Centaurea, Linn, 233.}

872. nigra, Liun. Black Knapweed. Pengaled leiaf benddu.

Common. Abundant. Native. Pascual, etc.

The distribution of the radiate and non-radiate forms has still to be worked out, especially to discover whether certain districts produce one form only. The non-rayed form appears alone in many districts, but the radiate form is apparently accompanied by the non-radiate. However, I noted radiate forms exclusively at Ewenny Down in 1908. Experimental cultures are required to determine accurately the relationships of the forms.

873. Scabiosa, Linn. Greater Knapweed. Crammenog fwyaf, Pengaled fwyaf.

Local. Abundant. Native. Agrestal, rupestral, etc.

Too common in the lowlands from Penarth to Worms Head for separate citation of the records. Aberdare; Hirwaun; Vale of Neath. $W$. A record requiring confirmation. Ed. Penllergare. Ridd.

b. succisafolia, E. S. Marshall. Cliffs at Port Eynon and Paviland! Ridd.

874. Cyanus, Linn. Corn-flower. Crammenog yr yd. Penlas yr yd. Local. Frequent. Alien. Agrestal, viatical.

Penarth! Pencoed, Bridgend. J.S. St. Brides Major. Miss B. Barry Island. D. Barry. M.A.D. St. Fagans, $V$. Merthyr. $E$. and $F$. Gowerton; Port Talbot; Aberdare; Mountain Ash. Ridd. Never, I believe, establishing itself anywhere in Glamorgan.

No. 877 occurs as an alien near some of the docks. The record in Watson's Topographical Botany should be excluded.

\section{Cichorium, Linn. 234 .}

879. Intybus, Linn. Wild Succory. Ysgallen y meirch, Y'sgallog gwyllt.

Local. Frequent. Native sometimes ; generally colonist and alien. Agrestal, viatical. 
Hedges on a limestone soil. N.S.G. Near Kilvey Hill. Gutch. Phyt. I842, p. 121. East Moors, St. Fagans, Whitchurch, Wenvoe. J.S. Gower, Aug., I835. Conway. Nat. Hb. Aberdare and Hirwaun. W. Vale of Neath. $H$. Barry Dock. D. Penarth! $H$. Whitchurch. $V$. Cwrt-yr-Ala. M.A.D. Southerndown. Miss $B$. and $V$. Ely Rise. I832. J.E. Cowbridge. T.H.T. S. Cornelau. Ridd. Gower, fairly common ! $L$. Native and frequent in Gower on the mountain limestone from the Mumbles to Rhossili and from Llangenydd to Llanrhidian. Probably an alien in most, if not all, of the other localities. Ed. Nash !

\section{Lapsana, Linn. 236.}

881. communis, Linn. Common Nipple-wort. Cartheig cyffredin. Common. Abundant. Native. Septal, viatical, etc.

\section{Picris, Linn. 237.}

\section{2. hieracioides, Linn.}

Local. Abundant. Native. Septal, etc.

Dry banks about Swansea. Flower \& Lees. Phyt. I843. p.379. E. Moors, Penarth! Llandough ! J.S. Southerndown! Miss B. and $V$. Monknash. T.H.T. Llanrhidian; Neath Abbey; Pyle; Porthcawl to S. Cornelau. Ridd. Swanbridge ! Bwlch-y-cwm ! Leckwith! Cwrt-yr-Ala! St. Hilary! St. Athans Road ! Penrice ! Oxwich! Peterston! and many other places of which no record has been kept. A plant of the calcareous soils, especially those on the mountain limestone.

883. echioides Linn. Bristly Ox-tongue. Tafod y llew. Gwylaeth chwerw.

Local. Abundant. Native. Viatical, agrestal, etc.

Swansea. Flower of Lees. Phyt. I 843. Penarth; St. Donats. J.S. Cliffs at Monknash. Miss B. Southerndown. M.A.D. Dunraven, Swanbridge. $V$. Barry Island. $I$. Overton; Port Talbot; Porthcawl; Roath and Pengam Moor. Ridd. Extends all along the S. coast of Glamorgan from Pengam Moor to Port Eynon; very abundant towards the east, especially on the newly weathered liassic clays; becoming rare to the west of the Ogmore. No inland localities on record. The nature of the habitat given in Bab. Man."dry banks," scarcely applies to Glamorgan. In this county the plant is generally found in "open formations," such as are constantly being formed by the weathering of the liassic cliffs. It does best on stiff clay soils.

\section{Crepis, Linn. 238.}

\section{5. taraxacifolia, Thuill.}

Local. Abundant. Recent Immigrant. Viatical.

Extends from Cardiff to Sully and Aberthaw along the embankments of the railways (T.V.R., Barry, and Vale of Glamorgan), and 
the new roads leading to the bridges, often forming the predominant vegetation. $E d$. Rhubina. $V$. Riverside. $H$. Crumlin Burrows; Pentyrch; Ystradowen; Aberdare. Ridd.

887. virens, Linn. Smooth Hawk's-beard. Gwalchlys llyfn. Common. Abundant. Native. Agrestal, etc.

889. biennis, Linn.

Rare. Scarce. Native? Pascual, viatical.

Sully, roadside, along with C. taraxacifolia. Llandough, Cardiff.

Ed. St. Athans. J.S. Oxwich Bay; Aberdare. Ridd.

89r. paludosa, Moench. Marsh Hawk's-beard.

Rare. Frequent. Native. Paludal, sylvestral.

Uscoed Eynon Gam. E. Forster, junv. B.G. Storrie's records for Llanishen and Caerphilly have not been confirmed and must be excluded.

\section{Hieracium, Linn. 239.}

The Hieracia will be treated separately in detail in the Appendix. Mr. Riddelsdell recognises 36 forms-species and varieties-as occurring in Glamorgan. The exposures of grits on the coal measures, coal tips, railway embankments, and slag hills, offer suitable habitats for these plants, and they should be systematically studied and collected. A good reference collection is being formed in the National Museum of Wales. There is no middle course between accepting the results of Linnaus-Species Plantanum, I753-and the modern work of a specialist like the Rev. W. R. Linton. There can be little doubt that the segregates recognised by Linton stand the test of experimental culture. As hybrids are rare, the forms cannot very well be due to the recombination of characters in the offspring of these. I have grown two closely allied forms from seed for two generations, and influenced by the results, suspect that most, if not all, of the recognised varieties are distinct and constant types.

For the present, the records furnished by correspondents may be summed up as follows:-

892. Pilosella, Linn. Mouse-ear Hawkweed. Heboglys torllwyd, Torllydig, Blewynog.

Common, Abundant. Native. Glareal, etc.

No. 893 has been recorded from near Caerphilly Tunnel, Green Meadow, Coedygoras, Coity, and Lisvane by J.S.; from Glyn Neath by E. F. Linton; and Graig Ymroch by Riddelsdell.

murorum, Linn. (including sylvaticum). Aggregate species. Common. Abundant. Native. Rupestral, sylvestral, etc.

sabaudum, Linn.

Local. Abundant. Native. Septal, etc.

Merthyr district. E. and F. Penllergare. G.T. Pwllypant. V. Taffs Well, Caerphilly, Cefn On, Rudry, Draethen. Ed. Park 
Mill ; Oxwich ; Gowerton ; Pantyffynon ; Pontardulais ; Kilvey Hill ; Ystalyfera; Neath Valley; Port Talbot; Pyle ; Aberdare ; Hirwaun; Porth. Ridd. Practically scattered all over the county. but no records from the valleys of the Ddaw and Ogmore.

\section{umbellatum, Linn.}

Local. Abundant. Native. Septal, etc.

Pitton and Pilton, Gower. U.C.Hb., Ed. Llandaff, Melingriffith. J.S. Hirwaun and Aberdare. IV. Merthyr. E. and F. Peterston. M.A.D. Caerphilly. $V$. Broughton Bay; Langland Bay; Groes Eynon and Penllergare; Neath Canal; Pontneddfechan. Ridd.

\section{Hypochœris, Linn. 240.}

996. glabra, Linn. Smooth Cat's-ear.

Recorded by Riddelsdell as a native, but from a locality, Porth. cawl sands, where many species have been introduced with ballast.

997. radicata, Linn. Long-rooted Cat's-ear. Melynydd gorwreiddiog. Common. Abundant. Native. Pascual, etc.

\section{Leontodon, Linn. $24 \mathrm{I}$.}

999. hirtus, Linn. Hairy Hawk-bit.

Common. Abundant. Native. Pascual, glareal, etc.

I 000. hispidus, Linn. Rough Hawk-bit. Peradyl garw.

Common. Abundant. Native. Pratal, pascual, etc.

I Oor. autumnalis, Linn. Autumnal Hawk-bit. Peradyl cynhauafawl. Common. Abundant. Native. Pascual, ericetal, \&c.

So abundant, that the fields in autumn in S.E. Glamorgan are often quite yellow.

\section{Taraxacum, Hall. 242.}

I 002. officinale, Web. Dandelion. Dant y llew cyffredin, Clais. Common. Abundant. Native. Pascual, etc., etc.

lavigatum, DC. Pwlldu! Oxwich! Ogmore and Ewenny Downs! Porthkerry! Barry! Sully! Swanbridge! Ed. Penard; Rhossili; Whitford Burrows; Broughton Sands; Sketty Burrows. Ridd.

erythrospermum (Andrz.) Gower; Hirwaun to Glyn Neath ; Kenfig ; Port Talbot; Swanbridge ; Aberdare; Taffs Well ; Morlais Castle. Ridd.

palustre (DC.) Aberdare; . Mountain Ash. Ridd.

udum (Jord.) Widespread according to Riddelsdell.

I have only recognised two types with certainty, and these appear to cross and produce intermediate forms. 'The experimental study of this aggregate would, I believe, be repaying. 


\section{Lactuca, Linn. 243.}

1003. virosa, Linn. Strong-scented Lettuce. Gwylaeth, Golaeth, Cyw. Llaethygen.

This alien has been recorded from the neighbourhood of most of the local docks. Oystermouth Castle. Gutch. Phyt. 1842, p. I21.

I004. Serriola, Linn. Prickly Lettuce.

This alien established itself on the hurricane beach at Sully about the year 1900, forming a close colony 20 yards long by a yard wide. It still persists there in diminished numbers. A fine example of a "compass plant."

1005. saligna, Linn. Least Lettuce.

This alien annual flourished for years on an old marl tip (from Penarth Dock ?), on the roadside near Llandough Railway Platform (I899 to I906), and was ultimately overcome, I believe, in the struggle for existence by the change in the vegetation of the tip from the "open " to the " closed " formation.

1006. muralis, Fresen. Ivy-leaved Lettuce. Gwylaeth y fagwyr.

Common. Abundant. Native. Rupestral, septal, etc.

\section{Sonchus, Linn. 245 .}

1009. oleraceus, Linn. Smooth Sow-thistle. Llaeth-ysgallen, Mochysgallen gyffredin.

Common. Abundant. Native. Agrestal, etc.

1010. asper, Hill. Rough Sow-thistle.

Common. Abundant. Native. Agrestal, etc.

Not so common as 1009 and IOII, but still too widespread for detailed record. Not always distinguished from 1009.

1011. arvensis, Linn. Corn Sow-thistle. Llaeth ysgallen, neu Mochysgallen yr âr.

Common. Abundant. Native. Agrestal, etc.

\section{Tragopogon, Linn. 246.}

IOI3. pratense, Linn. Yellow Goat's-beard. Barf yr afr felen.

Local, perhaps common. Abundant. Native. Pratal, pascual, viatical.

Singleton Marsh. Gutch. Phyt. 1842. p. I2I. Canton; Leckwith, etc. Common. J.S. Hirwaun and Aberdare. $W$. Merthyr District. E. and F. Llanedarne. J.S. (2) and T.H.T. Radyr. M.A.D. and $V$. Pengam. $V$. Penarth! $H$. Swanbridge! J.E. Barry Island. I. St. Brides Major. Miss B. Ely. G.T. Gowerton; Port Talbot; Bridgend; Laleston; Ogmore Castle. Ridd.

porrifolium, Limn. Alien. Recorded from:-Loughor. L.W.D.Mat. Maesteg. J.S. North side of Newport Road, beyond Pengam brook, plentiful. 25-5-93. J.S. (2). Barry. I., D., V. and $N$. 


\section{Campanulaceæ.}

\section{Lobelia, Linn. 247.}

IOI 5. Dortmanna, Linn. Water Lobelia. Bidlawglys dyfrdrig. Rare. Abundant. Native. Lacustral.

Llyn-fawr ! Llyn-fach ! B.G. Still abundant there. Ed.

\section{Jasione, Linn. 248.}

I017. montana, Linn. Sheep's-bit. Clefryn.

Common. Abundant. Native. Glareal.

Appears to be rare on the heavy clay lands of the Vale of Glamorgan, perhaps absent altogether.

c. littoralis, Fr. Porthcawl ! Mumbles to Caswell Bay! Ed. Aberafan ; Sker. Ridd.

\section{Wahlenbergia, Schrad. 249.}

Iо I 8. hederacea, Reichb. Ivy-leaved Bell-flower.

Local. Abundant. Native. Uliginal.

Frequent in the Neath Valley and other parts of the county. Plentiful about Pontypridd. B.G. Cwm Clydach. L.W.D.Mat. St. Fagans, Caerphilly ! Taff Valley, Pontypridd ! Quakers Yard ! etc. J.S. Tylacoch, etc. Fl. Rhondda. Hirwaun! W. Merthyr District. E. and F. Pentyrch. G.T. Castell Coch. H. Little Garth. M.A.D. Ystrad Rhondda. N. Penllergare ; above Pontardulais ; Pontardawe; Glyncorwg; Aberdare. Ridd. Llyn-fawr, and many other places, the plant being regarded as too common to demand record. Ed.

\section{Campanula, Linn. 25 I.}

1021. glomerata, Linn. Clustered Bell-flower. Clychlys.

Rare. Frequent. Native. Pascual.

By the sides of the hills in dry open pastures (near Swansea). Flower \& Lees. Phyt. 1843. p. 379. Near Dunraven ! Westcombe. Phyt. 1844. p. 780. T., M.A.D. and V. Penarth ! Storrie. The plant appears to be restricted now to the coast from St. Donats to Southerndown. Extinct at Penarth. A few years ago a few specimens appeared spontaneously in a garden at Penarth situated on the old habitat.

1022. Trachelium, Linn. Nettle-leaved Bell-flower. Clychlys dynadddail.

Local. Frequent. Native. Septal.

Between Penrice and Port Eynon ! E. Lees. Phyt. 1843. p. 379. St. Fagans, St. Andrews ! St. Hilary ! J.S. Llanbleddian, 
I907! Llanishen to Caerphilly, I908 ! Ed. Llandow ; Cowbridge ; Barry. Ridd.

1023. Iatifolia, Linn. Giant Bell-flower.

Rare. Scarce. Native. Sylvestral.

Coedriglan, Cowbridge. J.S. Merthyr Mawr! I892, U.C.Hb.

The record for No. I024-Merthyr Mawr-is almost certainly erroneous. $J$. of $B$. 1902. p. 317 .

1025. rotundifolia, Linn. Hare-bell. Clychlys amryddail. Cloch yr ëos.

Local. Abundant. Native. Rupestral, ericetal, glareal.

Often thinly scattered, but found in all parts of the county.

patula, Linn. Spreading Bell-flower.

Corner field at the junction of the new and old road on Stalling Down, July 8 th, I 83 . J.E. This is probably the record referred to by Dillwyn. "Said to have been found in the Vale of Glamorgan." L.W.D.Mat. A doubtful record, inserted to elucidate the entry in L.W.D.Mat.

No. 1029 is excluded.

\section{Vacciniaceæ.}

\section{Vaccinium, Linn. 253.}

1030. Vitis=idaea, Linn. Red Whortleberry.

Rare. Abundant. Native. Rupestral.

Craig-y-Llyn ! T.H.T. Padell-y-Bwlch ! Ridd. Nant-ygwddon. J.S. Near Braich-y-cymmer. J.S. (2). Blaenafan. T.H.T.

1032. Myrtillus, Linn. Common Bilberry. Llusen, Lluswydden, Mwyar y brain.

Local. Abundant. Native. Ericetal, sylvestral, \&c.

Common in the uplands; often the dominant species over large areas. Few records from the lowlands :-Penylan, Coedygoras. J.S. Taffs Well. H. Garth. M.A.D. and V. Rhubina. V. Clyne Wood. Ridd.

\section{Schollera, Roth. 254.}

1033. Oxycoccos, Linn. Marsh Cranberry. Llygaeron, Ceiros y waun. Local. Frequent. Native. Uliginal.

Mountains near Pontneddfechan. B.G. Ystradgynlais. L.W.D. Mat. Penllergare and Swansea. Gutch. Phyt. I842. p. 120. Cefn On, Caerphilly Common ! Llantrisant. J.S. Merthyr District $E$. and $F$. Ystrad Rhondda. N. Pendoylan. I., M.A.D. and V. Ystradowen. M.A.D. and $V$. Llantwit Fardre. Miss B. Pencoed. J.S. (2). Llanbradach. T.H.T. Mynydd Emroch; Aberdare. Ridd. 


\section{Ericaceæ.}

\section{Andromeda, Linn. 257.}

I 037. Polifolia, Linn. IVild Rosemary. Rhosmari grwyllt, Rhosus Mair.

Apparently extinct. Crumlyn Bog. E. Forster, junr. B.G. On Crumlyn Bog; till drainage took place, was rather plentiful towards the northern extemity. L.IV.D.Mat.

\section{Calluna, Salisb. 258 .}

I 038. Erica, OC. Heather. Grug cyffredin, Myncog.

Common. Abundant. Native. Ericetal.

As all the Evicacea are regarded as typical calcifuge plants, it may be of interest to put on record the habitats from the calcareous areas, in which it not infrequently occurs, in soils often shallow, relatively poor in humus, and with the roots practically in contact with the limestone. Ogmore Down! Miss B. Southerndown. $V$. Porthcawl ! $H$. Horton to Oxwich ! Ed. It appears to tolerate to a certain extent the mountain limestone, but not the Lias.

\section{Erica, Linn. 259.}

1 040. Tetralix, Linn. Cross-leaved Heath. Grug croesddeiliog. Common. Abundant. Native. Ericetal.

Occurring with 1038 , on limestone at Ogmore Down and in similar calcareous habitats, but not so frequent as 1042 .

1042. cinerea, Linn. Grey Heath. Grug lledlwyd.

Common. Abundant. Native. Ericetal.

Luxuriant and abundant in many places on the mountain limestone, especially on the S. coast of Gower.

All the heaths produce more or less white-flowered individuals.

\section{Pyrola, Linn. 263.}

I050. minor, Linn. Lesser Winter-green. Coedwyrdd bychan, Glesyn y gauaf.

"Near Uscoed Eynon Gam ; found by Dr. Jos. Hooker." L.W.D. Mat. This may have been a Breconshire record, but the record in Top. Bot., Second Edition, is credited to Glamorgan.

1051. secunda, Linn. Serrated Winter-green.

Rare. Scarce.

Craig-y-Llyn ! ! from I 892 onwards. Ed. Two localities ; one almost inaccessible now, the other discovered in 1905 in company with Dr. Salter, of Aberystwyth. 


\section{Monotropeæ.}

\section{Hypopitys, Scop. $26_{5}$.}

1053. Monotropa, Crantz. Yellow Bird's-nest. Cyd-dwf.

Rare. Scarce. Native. Sylvestral.

Margam. L.W.D.Mat. St. Fagans, 1874 and I885. J.S. Castell Coch, I899. J. Storrie. Spec! Miss Gibson, H., M.A.D., T.H.T. and Mr. Fiddian.

\section{Plumbaginea.}

Statice, Linn. 266.

1054. Limonium, Linn = Limonium vulgare, Mill. Great Sea Lavender. Llemyg.

Local. Abundant. Native. Littoral.

Typically, on the salt muds of the estuaries, but occasionally on rocks. Found in every suitable locality all along the coast, from the Rhymney to the Loughor, often forming regular meadows, as at Oxwich and Whitford.

b. pyramidalis, Syme. Barry Salt Marsh!! Ed. Oxwich Bay. Ridd. Scarcely a distinct variety-probably a state only.

I 556 . auriculafolia, Vahl. = L. binervosum, C. E. Salmon. Lesser Sea Lavender.

Local. Abundant. Native. Littoral.

Typically rupestral, especially abundant on the mountain limestone from Burry Holme to Southerndown. Localities few and plants scarcer on the other parts of the coast. Llantwit Major ! St. Donats! Leys! Ed. Tresillian! G.T. Sully! M.A.D. Barry Island. V. Marcross. T.H.T. Flat Holme!

Armeria, Linn. 267.

1058. maritima, Willd. Thrift. Archmain, Clustog Fair. Cenin ar fìr. Local. Abundant. Native. Littoral.

This species would be entered as common, but for the fact that there are no records for the coast from Swansea to the mouth of the Kenfig river.

\section{Primulaceæ.}

\section{Primula, Linn. 269.}

106r. acaulis, Linn. Primrose. Briallu cyffredin, Tewbannog fechan. Local. Abundant. Native. Sylvestral, septal, etc.

Too common in the lowlands for detailed record. Apparently often very rare in the upland valleys. 
"Extinct, but one plant found in Bodringallt Woods. July, 1902." Fl. Rhondda. Rare in the Hirwaun-Aberdare District. WV. No record from the Loughor Valley. Ridd. Probably occurs in every district, even in every parish.

The caulescent form is occasionally found. Llanmadoc. Ridd. Cross Common, Dinas Powis. U.C.Hb.

$\times$ veris. St. Brides Major and Southerndown. Miss B. Park Mill. L. Cogan, St. Fagans, St. Georges. J.S. Pencoed. J.S. (2). Southerndown; several forms-cowslip-oxlip, primrose-oxlip, etc. Spec ! V. Llanilid! Monknash ! Barry Island ! Porthkerry ! Ed. Llanmadoc; Baglan; Barry; Ystradowen. Ridd.

1062. veris, Linn. Cowslip. Briallu Mair sawyrus, Dagrau Mair, Llys y parlys.

Local. Abundant. Native. Pratal, pascual, etc.

So abundant in many parts of the Vale of Glamorgan that the fields are sometimes literally covered with them; scarcer elsewhere ; not uncommon on the sand dunes, where they seem singularly out of place. No records for the valleys of the Loughor, Tawe, and Neath. Occasionally about Hirwaun and Aberdare. W. Very rare in Rhondda Valley. Fl. Rhondda. Merthyr district. E. and F. Park Mill. $L$.

\section{Lysimachia, Linn. 271.}

I 068. vulgaris, Linn. Common Loosestrife. Trewynyn cyffredin.

Local. Abundant. Native. Paludal.

Neath Canal. Gutch. Phyt. 1842. p. I43. Llandaff, Pwllypant, St. Fagans, Llantwit Major ! J.S. Hirwaun and Vale of Neath. W. Merthyr district. E. and F. Pentyrch!J.S.(2)., M.A.D., $H$. and T.H.T. Lavernock ! H. Sully ! D. Ystradowen ! Peterston! M.A.D. and $V$. Not uncommon in Gower; Fairwood Common, Penybank. L. Llanharry ! Llansannwr ! Welsh St. Donats ! and other places in the Vale of Glamorgan. Ed. Crumlin Bog; Killay; Glais to Pontardawe; Neath; Jersey Marine; Kenfig Pool ; Llancaiach. Ridd. Bank of River Ogmore! Miss B. Thinly distributed, as a rule, all over the county; here and there, however, forming the bulk of the vegetation.

1071. Nummularia, Linn. Moneywort. Trewynyn ymlusgaidd.

Local. Abundant. Native. Paludal, inundatal, etc.

About Swansea. Flower and Lees. Phyt. 1843. Llanishen, St. Nicholas, Pencoed, Tondû. J.S. Rare; Gelli. Fl. Rhondda. Vale of Neath, but rare. $W$. Merthyr Mawr. Miss B. Porthkerry; Fonmon. D. Hensol. J.S. (2). Cwrt-yr-Ala! H. Park Mill. L. Peterston. M.A.D. Coedriglan; Gileston ! V. Pontardulais ; Aberdare; Llantwit Fardre. Ridd. Frequent in S.E. Glamorgan from the River Ddaw to Cardiff and Penarth. Dinas Powis 1 Lavernock! Sully! St. Hilary! etc. Ed. 
1072. nemorum, Linn. Wood Loosestrife. Trewynyn y coedwig, Gwlydd melyn Mair.

Common. Abundant. Native. Sylvestral.

\section{Glaux, Linn. 273 .}

1074. maritima, Linn. Black Salt-wort. Hel-las.

Common. Abundant. Native. Littoral.

\section{Anagallis, Linn. 274.}

1075. arvensis, Linn. Scarlet Pimpernel. Brathlys gwrryw, Gwlydel Mair, Llys y crymmau.

Common. Abundant. Native. Agrestal, glareal, etc.

b. carnea (Schrank.) Ogmore Castle. E.S.M., Ridd.

I o76. carulea, Schreb. Blue Pimpernel.

Local. Frequent. Colonist or alien, Agrestal, viatical.

Penllergare. L.W.D.Mat. Lavernock. J.S. and V. Barry Dock ballast, I89o. U.C.Hb. St. Brides Major. Miss B. Penarth, though now extinct. $H$. As a weed in Penarth garden, still persistent. S. Rowlands. Spec! Kenfig; Port Talbot; Porthcawl; Cardiff. Ridd.

1077. tenella, Linn. Bog Pimpernel. Gwlydd Mair y gors.

Common. Abundant. Native. Uliginal.

Though deserving of the record common and very abundant in the uplands, it is very thinly scattered through the Vale of Glamorgan, owing to the comparative scarcity of suitable habitats.

\section{Centunculus, Linn. 275.}

1078. minimus, Linn. Chaff-weed. Bril-lys coraidd.

Rare. Frequent. Native. Inundatal.

Below Pennard Castle. Ball. Bot. Gaz. A.B. Kenfig! Welsh St. Donats ! Pendoylan! Ed. Fairwood Common; Oxwich Bay. Ridd.

\section{Samolus, Linn. 276.}

1079. Valerandi, Linn. Brook-weed. Claerlys, Sammwl, Samylen.

Local. Frequent. Native. Paludal, etc.

Neath Canal. Gutch. Phyt. I 842. Pwllypant, Barry! Boverton! Dunraven! J.S. Pennard Castle! L. Leckwith. M.A.D. Ewenny ! Llantwit Fardre. Miss B. Treguff, Cowbridge, and St. Donats ! $I$. Kenfig ! $H$. Fontigary ! $V$. Barry Island ! Dinas Powis! Llandough! Penrice! Ed. Quoity Green ; Loughor; Tennant's Canal ; Crumlin Burrows; Neath; Aberafan to Baglan : Porthcawl. Ridd. So frequent that the plant has often been left unrecorded. 


\section{Oleaceæ.}

\section{Fraxinus, Linn. 277.}

1080. excelsior, Linn. Common Ash. Onen, Onwydden. The fruit:Allwyddau Mair (Glam.).

Common. Abundant. Native. Sylvestral.

\section{Ligustrum, Linn. 278 .}

1081. vulgare, Linn. Common Privet. Yswydden cyffredin.

Common. Abundant. Native. Rupestral, glareal.

Native on maritime rocks and sand dunes; mostly planted elsewhere.

\section{Apocynaceæ.}

Vinca, Linn. 279.

No. I082-major-has been recorded as an alien from Park Mill, Penylan Hill, Swanbridge! Dunraven, Llandough, St. Brides-superEly, Rhubina, Creigiau, Boverton, and Lavernock.

No. 1083-minor-has been recorded as a denizen or alien from Cwrt-yr-Ala! St. Athans, Pendoylan, Park Mill, Marcross, and Aberdare.

\section{Gentianeæ.}

\section{Blackstonia, Huds. 28I.}

1085. perfoliata, Huds. Yellow-wort. Canrhi felen.

Local. Abundant. Native. Pascual, etc.

Too common for detailed record in Gower ! and the Vale of Glamorgan! Records elsewhere few, as follows :- Between Drumau and Gwernllwynchwith. Gutch. Phyt. 1842, p. I42. Merthyr district. E. and F. Port Talbot; Ruperra! Rudry! Ridd. Kenfig!

\section{Erythræa, Renealm. 282.}

Some of the forms of this genus are very puzzling, and in the opinion of the Editor require much further study to satisfactorily separate them.

1 086. Centaurium, Pers. Common Centaury. Canrhi goch, Arlladlys, Bustl y ddaear, Ysgol Fair, Ysgol Crist.

Common. Abundant. Native. Pascual, glareal, etc. 
White flowered form frequent:- Taffs Well, J.S. (2). Ewenny, Llantwit Major. T.H.T. Penarth! Dinas Powis! Worms Head. N.S.G. and L.W.D.Mat.

\section{b. capitata, Koch.}

Whitford Burrows. E. F. Linton. J. of B. I892. p. 297. Kenfig Pool ! Marshall and Shoolbred. J. of B. 1902. p. 248. Sully Island, I905! Cliffs at Southerndown! Mumbles to Caswell Bay! Llantwit Major ! with the type; Ewenny Down! Ed. Near Worms Head; Port Eynon ; Crumlin Burrows; Port Talbot. Ridd.

1 088. littoralis, Fr. Narrow-leaved Centaury. Canrhi góch arfor.

Rare. Scarce? Native. Littoral.

Near Kenfig Pool. Marshall and Shoolbred. J. of B. 1902. p. 248. Crumlin Burrows. L.W.D. Mat. Mumbles, Gutch. Phyt. 1842. There are many additional records for this species, but as they almost certainly refer to $1086 b$. they must, for the present, be excluded. The records of Gutch and Dillwyn are doubtful; so that the evidence for the occurrence of this species in Glamorgan rests on the hurried visit of Messrs. Marshall and Shoolbred in 1902.

1089. pulchella, Fr.

Local. Frequent. Native. Littoral.

Crumlin Burrows; and near the Worms Head. B.G. Southerndown, July, 1835. Conway. Nat. Hb. Whitford Burrows! Oxwich Point! Kenfig Pool! Southerndown and Sutton! limestone rocks and sands. Ed. Port Eynon; Margam Moors; Porthcawl Sands ; The Leys. Ridd. Generally a scarce plant, but here and there in considerable abundance.

1090. capitata, Willd., b. spharocephala, Towns.

Porthcawl to Sker. Marshall and Shoolbred. J. of B. 1902. p. 248. Langland Bay; Welsh St. Donats. Ridd.

\section{Gentiana, Linn. 284.}

1095. Amarella, Linn. Autumnal Gentian. Crwynllys chwerw.

Local. Frequent. Native. Pascual, glareal.

Cefn On ! St. Hilary. J.S. Whitford Burrows ! Pwll du ! Boverton! Cross Common, Dinas Powis ! Cwrt-yr-Ala ! Barry Island ! 4 and 5-merous types frequent. Ed. Oxwich Burrows; Ewenny. Ridd. St. Brides Major. I. and $V$. Oxwich Point; near Penmaen. L. Travellers Rest. J.S. (2). Southerndown Road. $V$.

1097. campestris, Linn. Field Gentian. Crwynllys y maes.

Rare. Scarce. Native. Pascual.

Bridgend, Hirwaun. J.S. Near Porthcawl Rest. R.E. and F. Cundall. Heol-y-Mynydd, Southerndown; 1905, scarce ! Ed. Hirwaun. W. Pendoylan. I, and V. Maesteg. G.T. Castell Coch. H. 
Near Margam. T.H.T. Mr. Thomas also calls attention to the tetramerous flowers and somewhat unequal calyx of ro95 on Barry Island, a feature which sometimes causes confusion between this and the preceding species. Storrie excludes Barry in his MS. notes for this species.

Menyanthes, Linn. 285 .

1099. trifoliata, Linn. Common Buckbean. Ffaen y gors tierdalen, Meillion y gors.

Local. Abundant. Native. Lacustral, uliginal, paludal.

Thinly but widely distributed all over Glamorgan, from E. to W., uplands and lowlands, ascending to Llyn fach. At Oxwich, the chief factor in the conversion of one of the lakes into marsh land.

\section{I. Polemoniaceæ.}

No. Iror has been occasionally recorded as an escape.

\section{Boraginea.}

Cynoglossum, Linn. 288 .

1102. officinale, Linn. Common Hound's Tongue. Pigyl meddygawl, Tafod y bytheuad.

Local. Frequent. Native. Glareal, viatical, littoral.

All along the coast, often very abundant, but no inland records.

b. subglabrum, Mérat. Kenfig; Merthyr Mawr. Ridd.

\section{Symphytum, Linn. 290.}

I I 05. officinale, Linn. Common Comfrey. Cyfardwf, Llys y cwlwm. Local. Frequent. Native. Paludal, pratal.

About Swansea. Flower and Lees, Phyt. 1843. Cooper's Fields. J.S. Blaenrhondda Brook. Fl. Rhondda. Hirwaun and Aberdare. W. Merthyr District. E. and F. Park Mill. L. Southerndown. I., Miss B. and $V$. Penarth, Llandough. $H$. Canton; Llandaff. M.A.D. Rhubina; Pencisely. V. Porthcawl ! Sully and Cadoxton Moors! Ed. Mumbles; Llangenydd; Ystalyfera; Port Talbot; Merthyr Mawr; Cowbridge; Cwmparc; Ruperra. Ridd.

b. patens (Sibth.) Swansea. Flower and Lees. Port Talbot; Taffs Well ; Ridd. Cadoxton Moors! 


\section{Borago, Linn. 291.}

1107. officinalis, Linn. Common Borage. Bronwerth, Tafod yr ych, Glesyn cyffredin.

Local. Frequent. Alien. Viatical.

Port Tennant and Cadoxton-juxta-Neath. Gutch. Phyt. 1842. Near St. Donats, white-flowered. Westcombe. Phyt. I844. p. 780. Llandough, 1830. J.E. E. Moors, Llandough! Pwllypant, Llantrithyd. J.S. Dunraven. Miss B. St. Athans ! D. Llantwit Major ! J.S. (2). Radyr, Llandough ! H. Marcross ! M.A.D. Merthyr. T.H.T. Leys!

\section{Anchusa, Linn. 292.}

I 1 09. Sempervirens, Linn. Evergreen Alkanet. Llys y gwrid.

Local. Frequent. Denizen or native. Septal, etc.

Baglan. J. Woods, junr., B.G. Neath Abbey, Briton Ferry. Dillwyn. Cornely. Bicheno. L.W.D.Mat. Penarth, Llandaff, Dusty Forge, St. Fagans, Bridgend. J.S. Cymmer, Porth. Fl. Rhondda. Cynon Valley and Vale of Neath. WW. Abercynon. E. asid F. Norton, Southerndown. Miss B. Burdonshill. D. Coedriglan. G.T. Sully! Taffs Well. $H$. Llandaff, I83 I. J.E. Fairwater. M.A.D. Saintwell! $V$. St. Athans! Ely! Wenvoe! St. Donats! Ed. Merthyr Mawr; Aberthin; Marcross. Ridd. Looks native in many places.

\section{Lycopsis, Linn, 293.}

I I 0. arvensis, Linn. Small Bugloss. Bleidd-drem, neu Tafod yr ych culddail.

Local. Frequent. Native. Glareal, agrestal, etc.

Thinly scattered along the coast from the Ogmore westwards to Whitford Burrows ; rare and scarce elsewhere, the only localities on record being:--Sully! St. Fagans. J.S. Aberdare. Ridd.

No. III2-Pulmonariu officinalis-is recorded as an alien as follows:-Woods between Neath and Pyle. B.G. Coedriglan, Wenvoe, Dunraven. J.S. Dunraven. Miss B. Sully. J.S. (2).

\section{Myosotis, Linn. 296.}

\section{4. caspitosa, F. Schultz.}

Common. Abundant. Native. Paludal.

The commonest and least attractive of the aquatic Forget-me-nots.

I I 5. palustris, Relh=scorpioides, Linn. Forget-me-not. Ysgorpionlys y gors.

Local. Abundant. Native. Paludal.

Swansea. Flower and Lees. Phyt. 1843. Llanishen, St. Fagans ! Culver House, Cadoxton, etc. J.S. Blaenrhondda. Fl. Rhondda. Hirwaun; Vale of Neath. IV. Merthyr district. E. \& F. Gower-not common, Miss B. Cadoxton Moors! D. Penarth! 
H. Garth. M.A.D. Kenfig ! Cwrt-yr-Ala ! Sully Moor ! Cwm Alun! St.-y-Nil ! Ed. Crumlin Bog; Aberafan ; Ewenny; Barry to Bonvilstone; Flemingstone Moor. Ridd. No doubt numerous other localities, as the plant is met with so frequently that it is passed over as not worthy of special record.

b. strigulosa, Mert and Koch. Neath; Aberdare, Ridd. Cwrtyr-Ala! $E d$.

III6. repens, G. Don.

Local. Abundant. Native. Paludal, uliginal.

Crumlyn Bog. Flower and Lees. Phyt. I843. E. Moors. Grangetown, Leckwith, St. Fagans. J.S. Pontygwaith. Fl. Rhondda. Hirwaun; Vale of Neath. $I V$. Fairwood; Penmaen. L. St. Athans Road ! Pontypridd ! St.-y-Nil ! Ed. All over Glamorgan, except the valley of the Ogmore. Ridd. Very wide-spread; but definite records needed. Treated as local owing to the absence of records from numerous correspondents.

I I 8. sylvatica, Hoffm. Wood Forget-me-not.

Local. Frequent. Native. Denizen or alien. Sylvestral.

Coedriglan Woods - alien. J.S. Bodringallt Woods-two plants, Fl. Rhondda. Cheriton; Merthyr Mawr; Aberdare ; as alien. Ridd. Merthyr district. E. \& F . Park Mill. $I$. Pendoylan, looking native. $I ., M . A . D$. and $V$. Not infrequent as a casual.

I I 9. arvensis, Lam. Field Forget-me-not.

Common. Abundant. Native. Agrestal, septal, \&c.

I 120. collina, Hoffm. Dwarf Forget-me-not.

Local. Abundant. Native. Glareal.

Common all round the coast. The seeds germinate in autumn, the plants grow vigorously during the winter, flower in early spring, and die off during the first droughts of summer. Inland localities on record are:-St. Lythans. I. Llandaff Mill. M.A.D. and $V$. Bishopston; S. Cornelau; Aberdare; Caerphilly. Ridd.

I 2 I. versicolor, Reichb. Yellow and Blue Forget-me-not.

Local. Frequent. Native. Glareal, etc.

About Spitty, rare. L.W.D.Mat. Llandaff, St. Fagans, Caerau, Wenvoe, etc. J.S. Occasionally about Hirwaun and Aberdare. $W$. Pendoylan; Pontcanna. I. Southerndown. Miss B., V. and M.A.D. Coedriglan. $I$. Cwrt-yr-Ala. $H$. Near Pennard Castle, not common. L. Penmaen; Llangenydd ; Rhossili ; Killay; Barry ; Mountain Ash; Taffs Well; Welsh St. Donats. Ridd. Some of the records may refer to $M$. collina.

\section{Lithospermum, Linn. 297.}

I I 22. purpureo-cœruleum, Linn. Purple Gromwell.

Local. Abundant. Native. Sylvestral and littoral.

Near Porthkerry, July 2nd, I773. Lightfoot. J. of B. 1905. p. 299. Several places on the coast of Gower, particularly Nicholaston 
Wood and Caswell Bay; Newton-juxta-Pyle, by The Rev. J. M. Traherne; about Porthcawl, by Mr. Bicheno. Gutch. Phyt. I842. p. I41. Barry! Porthkerry! Boverton, Dunraven! J.S. Southerndown. $I$. Park Mill, but nearly extinct. $L$. Aberthaw! abundant. $E d$. Dunraven. Miss $B$. and $V$. Newton Nottage. Miss $B$. Oxwich Point; Bishopston and Penrice; Monknash. Ridd. Scattered here and there in bushy places along the coast from Barry to Oxwich Point.

1123. officinale, Linn. Common Gromwell. Maenhad meddygawl. Grawn yr haul.

Local. Frequent. Native, Glareal, rupestral, sylvestral, etc. Park Mill. Gutch. Phyt. 1842, and L. Barry, Llantrithyd. $J$.S. Southerndown. Miss $B$. Cowbridge to Cardiff. D. Llandaff. J.S. (2). Cwrt-yr-Ala ! H. Candlestone; Llantrithyd. M.A.D. Garth ! Dinas Powis ! Whitford Burrows ! very abundant ; and frequent elsewhere in Gower. Newton Nottage ! Ed. Penllergare; St. Donats to Monknash; Barry Island; Llandough. Ridd.

No. I 24 occurs sporadically about the local docks, and has been recorded besides from Dunraven, Rhossili, Bishopston, Aberdare, and Hirwaun. Always alien.

\section{Echium, Linn. 298.}

I 125. vulgare, Linn. Common Viper's Bugloss. Gwiberlys cyffredin, Bronwerth y wiber, Tafod y bwch.

Local. Abundant. Native. Glareal, viatical.

Near the Infirmary, and Town Hill, Swansea. Gutch. Phyt I 842. Penarth, Sully. J.S. Aberdare and Hirwaun. W. Merthyr District. E. and $F$. Taffs Well! Swanbridge ; Sully, I89I ; between Newton Nottage ! and Porthcawl ! I894. T.H.T. Swanbridge, 1838. J.E. Frequent, cliffs and sands at Pennard. L. Merthyr Mawr. Miss B., M.A.D. and V. Kenfig! Lavernock. H. Oxwich; Crumlin Bog; Jersey Marine; Aberafan; Leys. Ridd. Chiefly on the sand dunes and tips from collieries or iron works.

\section{Convolvulaceæ.}

\section{Volvulus, Medic. 299.}

I 1 27. sepium, Junger. Large Bindweed. Cynghafawg fawr, Cloffrwym y mwcci, Clych y perthi.

Common. Abundant. Native. Septal.

The rose-coloured form was recorded from Swansea and Gower by Gutch in 1842 , and still grows in several places in Gower. 1908 . Ed. 
I 28. Soldanella, Junger. Sea Bindweed. Cynghafawg arfor, Ebolgarn y môr.

Local. Frequent. Native. Glareal and littoral.

Occurs along the coast on the sands from Sully to Port Eynon. Rare and scarce east of the Ogmore, commoner towards the W. No records for the Whitford Burrows.

\section{Convolvulus, Linn. 30n.}

I 29 . arvensis, Linn. Small Bindweed. Cynhafawg fechan, Taglys. Common. Abundant. Native. Agrestal, viatical.

\section{Cuscuta, Linn. 301.}

I 31 . europaea, Linn. Great Dodder. Llinclwm, Llindag, Llindro, Cwlwm y coed, Cwlwm y gwydd.

Newton sands, not flowering. Ridd. This is probably referable to either I I 32 or I 133 .

I 32. Epithymum, Murr. Lesser Dodder.

Rare. Scarce. Native. Parasitic.

Near Pwlldu, Gower, I 892 , very abundant on Ulex. U.C.Hb. No longer there apparently in 1908. Exterminated probably by the burning of the furze.

I133. Trifolii, Bab. Clover Dodder.

There are two definite records for this alien plant. Pontcanna, on Trifolium pratense. J.S. (2). Gileston, on clover. T.W. Proger. Not uncommon on clover in Glamorgan. Mr. Hedger Wallace. A number of additional records for Cuscuta are probably to be placed here, the parasite growing on various herbaceous plants. Dunraven! On Centaurea nigra and Lotus corniculatus. $M r$. Mitchell and $V$. Cogan Pill on Potentilla reptans. Miss Corbett, 1897. Sp! Horton! Near Oxwich! 1908. U.C.Hb. On various herbaceous plants, Hypocharis radicata, etc. Ed.

\section{Solanaceæ.}

Solanum, Linn. 302 .

1 134. Dulcamara, Linn. Woody Nightshade. Elinog, Mynyglog. Common. Abundant. Native. Septal, paludal, littoral, etc.

b. marinum, Bab. Oxwich! Sully Island ! Ridd.

1135. nigrum, Linn Black Nightshade. Mochlys cyffredin, Mochlys grawnddu.

Local. Frequent. Native? Viatical, agrestal.

East Moors and Penarth. J.S. Llanmorlais. E. F. Linton. J. of B. 1892. p. 296. Swanbridge, 1830. J.E. Penarth! H. Swan- 
bridge ! to Barry ! $H$. and $V$. Flat Holme, abundant in 1890 . J.S. (2). Sully Island. D. Southerndown. Miss B. Merthyr Mawr. M.A.D. Fairwater. I. Cwm Ivy ! and Whitford Burrows! but with Datura Stramonium. Ed. Port Talbot; Newton Nottage; Aberdare. Ridd.

\section{Lycium, Linn. 303.}

I 136 . barbarum, Linn. Tea-plant.

Local. Abundant. Denizen. Septal, rupestral, littoral, etc.

Swanbridge ! $H$. and $V$. Sometimes fruiting well, spreading by seeds freely, and rooting into the barren red marls. An outcast probably elsewhere. Pennard to Killay; Port Talbot; Porthcawl ; Ystradowen. Ridd.

\section{Atropa, Linn. 304.}

1 37. Belladonna, Linn. Deadly Nightshade. Codwarth.

Rare. Scarce. Native?-probably denizen. Viatical.

Llandaff Cathedral. N.S.G. This locality was confirmed by Dillwyn. L.W.D.Mat. Mumbles, 1839. Two specimens. Gutch. Phyt. 1842. p. 143. Llandaff Churchyard, but extinct since 1873 . J.S. Boverton! J.S. It still exists in this locality, where it is not so native as it appears. Ed. Ruins of White Friars, Cardiff, where it sprang up spontaneously on the rubbish removed whilst laying bare the foundations. J.S. (2). In Horse-radish lane, June 24 th, I 830 . J.E.

\section{Hyoscyamus, Linn. 306.}

1139. niger, Linn. Common Henbane. Parfyg yr iar, Ffaen y moch, Crys y brenin.

Local. Frequent. Native. Glareal, viatical, etc.

Frequent in Gower; Crymlyn Bog ; near Neath Canal. Gutch. Phyt. I842. E. Moors, Grangetown, Penarth, Sully, Barry, Llantrithyd. J.S. Mumbles, July, I 834. Nat.Hb. Aberdare and Hirwaun. $W$. Cefn, near Merthyr. E. and F. Dinas Powis! J.S. (2). Sully Island ! Flat Holme! H. Barry! M.A.D., V. and $D$. Southerndown! Miss B., M.A.D. and V. Penmaen. L. Llan. dough, 1830. J.E. Llangenydd and other places in Gower! T.H.T. About Port Talbot; Llanbleddian. Ridd. Sker ! Porthcawl ! Merthyr Mawr ! Kenfig !

\section{Scrophularinæ.}

\section{Verbascum, Linn. 307.}

I I 40. Thapsus, Linn. Great Mullein. Tewbannog, Sircyn y melynydd, Tapr dunos, Tapr Mair, Haner pan, Clust y fuwch, Clust y tarw, Canwyll yr adar, Dail melved. 
Local. Frequent. Native. Viatical, septal, etc.

Although not common, the localities are too numerous for separate record.

I 1 43. nigrum, Linn. Black Mullein.

Rare. Scarce. Native? scarcely a denizen in most stations. Viatical.

Briton Ferry. Flower and Lees. Phyt. 1843. p. 379. Sparingly on the sandhills at Porthcawl. R. E. and F. Cundall. J. of B. I902. As an alien at Hirwaun some years ago. $W$. Merthyr District. $E$. and $F$. Near the shrimp house, Cardiff. J.S. (2). Lower Penarth! $H$. Not infrequent about the local docks, where, however, it does not maintain its ground for more than a few years. $E d$. Llanmadoc, and frequent on cliffs. Ridd.

\section{144 . virgatum, Stokes.}

This plant has flourished for many years on a railway embankment between Cardiff and Penarth, notwithstanding the fact that it is frequently cut down during the mowing of the banks. Near Cardiff. J.C. Collins. N.B.G.

\section{145. Blattaria, Linn.}

Rare. Scarce. Alien. Viatical.

Swansea. B.G. Neath Abbey; Taibach; Margam; Singleton Marsh; Pyle. Gutch. Phyt. I842. Kenfig. L.W.D.Mat. St. Fagans, Tondû. J.S. Llandaff. G.T. Newton Nottage sands, near the Well, with white flowers. I th August, 1894. J.S. (2). Near Mawdlam Church. R.E. and F. Cundall. I902. J. of B. p. 3I6. Aberafan. Ridd.

\section{Linaria, Mill. 308.}

I I 46. Cymbalaria, Mill. Ivy-leaved Toadflax. Trwyn y llo eiddewddail.

Local. Frequent. Native or denizen. Rupestral.

Very abundant in the lowlands, less frequent in the uplands, but occurs all over the county. Its status needs investigation; its present position as an alien being apparently based (I) on a careless interpretation of Dillenius's account of its escape from the Chelsea garden (Why should not a native plant escape from a London garden ?) ; and (2) on Watson's somewhat irrelevant and not quite correct generalisations- $(a)$ that the species occurs only on walls, and (b) that it is injured by frost. The plant grows in masses sometimes yards across, on an old pebble ridge at the Leys, in company with two rupestral natives-Ceterach officinarum and Asplenium Rutamuraria, and is quite able to withstand the winters of South Wales, as well as those of places much further North.

I I 47. Elatine, Mill. Sharp-leaved Fluellin. Trwyn y llo blaenfeinddail. Local. Frequent. Colonist, possibly native in Gower. Agrestal, pascual. 
Swansea. Flower and Lees. Phyt. I 843. E. Moors and Penarth ! J.S. Barry Island. J.S. (2). Barry. D. Penarth! common. $H$. Southerndown. M.A.D. and $V$. Waterhall railway siding. $I$. Cogan, Michaelstone-le-pit! Aberthaw! Horton! under burnt furze bushes. Ed. Penllergare; Crumlin Bog; Graigafan; Porthcawl; Llantwit Major. Ridd.

1148 . Spuria, Mill. Round-leaved Fluellin.

Local. Frequent. Colonist. Agrestal.

Swansea. Flower and Lees. Phyt. 1843. p. 379. E. Moors and Penarth. J.S. Penarth! common. H. Coedriglan; Barry Island. J.S. (2). Cogan Pill. M.A.D. Gileston. T. W. Proger. Romilly Park, Barry. D. St. Hilary, Gigman Mill. V. Michaelstone-le-pit! Cogan! Llantwit Major! Ed. Horton; Porthcawl; St. Athans; Lavernock. Ridd. Nos. I 47 and I 48 are apt to occur side by side in the same habitat, an unusual occurrence with closely related species. and to be explained perhaps by the fact that the struggle for existence is with the cultivated plants, not with each other, in the case of agrestal plants like these.

I 152. repens, Mill. Striped Toadflax.

Local, Frequent. Denizen, scarcely native. Viatical.

Near the local docks, probably introduced with ballast, frequent from at least 1837 (N.B.G.) to the present time. Rare elsewhere. Inland records:-Llantwit Fardre. Miss $B$. Merthyr. E. and F. Pwllypant. M.A.D. These all need confirmation.

$\times$ vulgaris. About Cardiff and Penarth; growing on one embankment with its two parents, setting seed freely and forming a colony covering many square yards. The problem as to the origin of the hybrid colony,--from seeds or by vegetative means of reproduction, has still to be solved. The attempt to secure hybrid seed in 1907 failed, owing to the mowing of the plants. This hybrid should be raised experimentally, and its progeny determined with accuracy.

I I53. vulgaris, Mill. Yellow Toadflax. Llïn y llyffant, Gwrnerth. Llysiau Llewelyn, Llïn y forwyn, Gingroen fechan.

Common. Abundant. Native. Septal.

The peloric form occasionally occurs. On the way to Penarth Ferry. I893. T.H.T., Nat.Hb.

I 54. viscida, Moench.=L. minor, Desf. Least Toadflax.

Local. Abundant. Colonist. Agrestal, viatical.

Sandy meadows near Swansea. Flower and Lees. Corrected to sandy cornfields near Swansea. L.W.D.Mat. Penarth! agrestal. H. Southerndown, in fields. Miss B. Barry. D. Merthyr. E. and F. This plant is found, often in abundance, between the metals of the local railway lines, and often forms the sole vegetation in such places. Records for such situations include Hirwaun, Aberdare, Peterston! Ely! Ystradowen! St. Georges ! St. Fagans ! S. Cornelau, Bridgend ! Grangetown! The most typical plant of the railway "ballast" in. Glamorgan.

No. I I 56 is excluded. 
Scrophularia, Linn. 3 ro.

I I 57. aquatica, Linn. Common water Figwort. Gornerth y dwr, Dannogen y dwr.

Common. Abundant. Native. Paludal.

b. cinerea, Dum. Gowerton; Peterston; Aberdare. Ridd.

I 59. nodosa, Linn. Knotty-rooted Figwort. Deulen ddu dda, Gornerth neu Goreunerth.

Common. Abundant. Native. Septal, inundatal.

An interesting green form of this grows side by side with the type on Sully Island. At first sight it appears distinct, but if all the plants of the colony are observed carefully, every gradation can be traced between the two extremes. The problem in this case is one in experimental physiology, not in taxonomy. It is probable that this is the plant (or condition) referred to in Ray. Syn. 2nd Edition, p. I6I; a reference furnished by Mr. A. Bennett to the Hon. Secs.

I 60. Scorodonia, Linn. Balm-leaved Figwort.

Alien. Extinct at Cardiff. J.S. Porthcawl sándhills. R.E. and F. Cundall. J. of B. I902. p. 3I6.

\section{Mimulus, Linn. 311.}

1162. luteus, Linn $=$ M. Langsdorfii, Donn. Yellow Monkey-flower. Local. Frequent. Denizen. Paludal, etc.

Caerphilly Common, spreading a good deal. J.S. Treforest ! and near top of Rhondda Valley. J.S. (2). Dunraven and Ystrad Rhondda. Fl. Rhondda. River Neath. $W$. Merthyr District. $E$. and F. Banks of River Ogmore. Miss B. Vale of Neath. H. and G.T. Taffs Well! M.A.D. Tongwynlais. V. Cheriton! Ilston, and Ilston Cwm. L. Common by River Loughor; Baglan; Cowbridge. Ridd.

\section{Limosella, Linn. 312.}

I 63. aquatica, Linn. b. tenuifolia, Lej. Mudwort. Lleidlys. Rare. Abundant. Native. Lacustral, inundatal.

Kenfig Pool! Marshall and Shoolbred. J. of B. I901. p. 336. Crumlin Bog. Ridd.

This plant was collected by the Editor, in flower, at Kenfig, Whitsuntide, 1897 , thus fixing its occurrence in this locality three years earlier than the date of its discovery by Marshall and Shoolbred. As I had never collected Limosella before, I regarded it simply as L. aquatica. I failed to collect it in I898, when it must have been either very scarce or covered by water. In $1905 \mathrm{I}$ found it in great quantity all round the sandy shores of the pool, with the exception of the bay on the North side. It extended from high to low water mark, being most abundant about midway between these. Germination and growth appear to take place under water; as the level of the water 
sinks and exposes the plants, they come into flower in succession, so that flowering and fruiting specimens can often be obtained at the same time.

\section{Sibthorpia, Linn. $3 \mathbf{I} 3$.}

1 64. europæa, Linn. Cornish Moneywort. Ceinioglys Cerniw.

Rare. Scarce. Native. Uliginal, etc.

Pontypridd. Sir J. Cullum. B.G. Pwllypant, Pontypridd Common! J.S. Still in the latter locality in 1905. Ed. Taffs Well. $M . A . D$. and $V$. Foot of Graig, Llantrisant; and wall sides and road running $\mathrm{N}$. from Pontypridd. $V$. A mountain W. of Taff Valley at height of 500 to 600 feet. T.H.T. Near Ystrad Mynach. Mr. A. Pettigrew. Sp! Between Pontypridd and Porth. Mr. Nance. Caerphilly. Ridd.

\section{Digitalis, Linn. 314.}

I 165. purpurea, Linn. Foxglove. Ffion y ffride, Bysecld cochion, Menyg y llwynog, Menyg ellyllon.

Common. Abundant. Native. Sylvestral, septal.

\section{Veronica, Linn. $3 \mathbf{1 5}$.}

I 66. hederæfolia, Linn. Jvy-leaved Speedwell. Rhwyddlwyn eiddewddail.

Local. Abundant. Native. Agrestal.

Too common in the lowlands, from Penarth to Oxwich, for detailed record. Records for the uplands as follows:-Penrhys Brook; near Mardy Cemetery. Fl. Rhondda. Merthyr District. $E$. and $F$. Aberdare. Ridd. No record from the valley of the Loughor.

\section{167 . polita, Fr.}

Local. Frequent. Native. Agrestal.

Swansea. Gutch. Phyt. 1842. p. 143. Carcliff. R. W. Rickards. $J$. of B. 1884. p. 260. A common weed of Penarth gardens. Ed. Barry. $D$. Probably included by our correspondents under Ir68. Mr. Riddelsdell records it from most parts of the lowlands (excepting the valley of the Loughor) and from Ystalyfera, Aberdare, Merthyr Tydfil, and Caerphilly.

I 68 . agrestis, Linn. Procumbent Speedwell. Rhwyddlwyn gorweddawl. Local. Frequent. Native. Agrestal.

Swansea. E. F. Linton. J. of B. 1892. p. 296. Leys ! U.C.Hb. Horton ! Ed. Gower; Porthcawl; Cadoxton ; Swanbridge; Aberdare; Hirwaun. Ridd. The following records, by correspondents who have not recognised $V$. polita, must be regarded as for the aggregate I 167 and I 168 . Aberdare and Hirwaun, common. IV. Merthyr District. $E$. and $F$. Penarth $H$. Gower. $L$. St. Brides Major. $V$. 
1 69. Tournefortii, C. Gimel $=$ V. Buxbaumii, Ten.

Common. Abundant. Colonist. Agrestal.

I 72. arvensis, Linn. Wall Speedwell, Mur-rhwyddlwyn.

Common. Abundant. Native. Glareal, agrestal.

1 173. serpyllifolia, Linn. Smooth Speedwell. Rhwyddlwyn grywddail. Common. Abundant. Native. Pascual, etc.

There are three records for $b$. humifusa, but these must be excluded in the absence of specimens, especially as two of the localities are at low levels.

Three old records for No. I 777 are exciuded, as based either on errors or casuals.

I I 7. officinalis, Linn. Common Speedwell. Rhwyddlwyn meddygawl, Gwrnerth, Llys Llewelyn.

Common. Abundant. Native. Ericetal, etc.

1 179. Chamadrys, Linn. Germander Speedwell. Rhwyddlwyn blewyinnawg.

Common. Abundant. Native. Septal, etc.

I I 80. montana, Linn. Mountain Speedwell. Rhwyddlwyn mynyddawl.

Local. Abundant. Native. Sylvestral.

Would be reported as common, but that there are no records from the valleys of the Loughor and Tawe. Extends from Penarth to Llanmadoc, Merthyr, and Hirwaun.

I 81. Scutellata, Linn. Narrow-leaved Speedwell. Rhwyddlwyn culddail y gors.

Local. Abundant. Native. Paludal, etc.

Neath. Flower and Lees. Phyt. I 843. E. Moors, Leckwith, Penarth to Cardiff, St. Fagans. J.S. Hirwaun. IV. Merthyr District. E. and F. Pendoylan! V. Ewenny. Miss B. Oxwich Marsh ! L. Pontypridd ! St.-y-Nil ! $E d$. Frequent in Gower; Gowerton Common; Mynydd Garngoch ; Margam Moors ; Barry ; Aberdare; Ystradowen. Ridd.

I 82. Anagallis-aquatica, Linn. Water Speedwell. Graeanllys y dwr. Local. Abundant. Native. Paludal.

Very abundant in the lowlands. No records from the Loughor Valley, and the uplands.

I 183 . Beccabunga, Linn. Brooklime. Goferini, Llychlyn y dwr, Llysiau Taliesin, Yr henwr.

Common. Abundant. Native. Paludal.

\section{Euphrasia, Linn. 316.}

1184. officinalis, Linn. Common Eyebright. Goleudrem, Golyglys, Gloewlys, Effros.

Common. Abundant. Native. Pascual, ericetal, etc. 
The segregates are still imperfectly defined, and it is hoped that it may be possible to give a more satisfactory account of them in the Appendix than is at present possible. The numbers are those of the London Catalogue, tenth edition.

1260. Rostkoviana, Hayne. Gowerton to Penclawdd; Pontarlulais to Pantyffynon; Hirwaun Common ; Aberdare; Welsh St. Donats ; Ridd. Pendoylan! Llansannwr! Ed.

1262. brevipila, Burnat and Gremli. Margam Burrows. Marshall and Shoolbred. J. of $B$. 1902. p. 248. Aberafan to Baglan. Ridd., Nat.Hb. Penmaen; Llangenydd ; Port Talbot; Barry Island ! Aberdare ; Caerphilly. Ridd. Llansannwr ! Ed.

1265. borealis, Towns. Aberdare. Ridd.

1266. stricta, Host. Aberdare. Ridd.

1267. nemorosa, H. Mart. Aberafan; Porthcawl to S. Cornelau; Aberdare; Ystradowen. Ridd. Tresillian! ! verified by Townshend, to whom were sent three very different living plants to see if plants altered by conditions of nutrition were being named. Taffs Well to Caerphilly! Barry! Cwrt-yr-Ala ! Hensol Lakes ! Heol-y-Mynydd ! Pontypridd! Cogan ! Lavernock ! Llandough ! Horton and Port Eynon, differentiating into two sub-types. Ed. This is the commonest segregate in Glamorgan, and appears to pass by intermediate forms into brevipila and Rostkoviana.

1269. scottica, Wettst. Aberdare? Ridd.

1270. occidentalis, Wettst. Barry Island. Ridd. Ogmore Down! near the links. A very distinct variety. Ed.

1271. curta, Wettst. b. glabrescens, Wettst. Rhossili; Oxwich ; Llangenydd; Aberafan; Kenfig Pool ; Porthcawl! Llantwit Major to Monknash; Welsh St. Donats. Ridd. Southerndown to mouth of Ogmore $1 E d$.

\section{Bartsia, Linn. 317.}

I I 85. Odontites, Huds. Red Bartsia. Goradd, Gwaedlys bychan.

Common. Abundant. Native. Pascual, etc.

The segregate $b$. serotina is common, and recorded from most parts of the County. a. verna is rare. Rhossili to Llangenydd; S. Cornelau. Ridd.

I 186. viscosa, Linn. Yellow Bartsia.

Rare. Frequent. Native. Paludal, etc.

Drymma; Crumlyn Dingle; to the left of the old road between Swansea and Neath. L.W.D.Mat. Between Bridgend Asylum and Gwaith-yr-haiarn. J.S. Penybank, near Fairwood Common, rare. L. Aberafan and Baglan. Ridd. 


\section{Pedicularis, Linn. 318.}

I I88. palustris, Linn. Upright Lousewort. Melawg y waun, Mel y gweunydd.

Local. Abundant. Native. Paludal, uliginal.

Penllergare; Crymlyn Bog; Fairwood Moor. Gutch. Phyt. I842. St. Georges, near Culver House, St.-y Nil. J.S. Tylacoch ; Mardy. Fl. Rhondda. Hirwaun. $W$. Vale of Neath. $H$. Llangynwyd; Bettws; Upper and Lower Neath ; near Onllwyn. T.H.T. Kittle. L. St. Athans. Miss B. Eglwys Brewis. D. Castell Coch. H. Whitford Burrows! Oxwich! Penrice! Llanishen! Ed. Jersey Marine; Porthcawl. Ridd.

I 89. sylvatica, Linn. Procumbent Lousewort. Melsugn y borfa, Mel y cwn.

Common. Abundant. Native, Ericetal, etc.

\section{Rhinanthus, Linn. 3rg.}

I 190. Crista-galli, Linn. Yellow Rattle. Cribell melyn, Arian y gweir. wyr, Arian Gwion.

Common. Abundant. Native. Pascual, pratal, etc. Ascends to I 500 feet on Craig-y-Llyn.

\section{Melampyrum, Linn. 320.}

I 94. pratense, Linn. Common Cow-twheat. Gliniogai melyn, Bewlith, Buelith.

Local. Abundant. Native. Sylvestral.

Thinly scattered all over the county, in localities too numerous to record individually.

d. montanum, Johnst. Rhigos; hills above River Perddyn. Ridd.

e. hians, Druce. Pantyffynon to Pontardulais; Upper Neath Valley; Aberdare; Hirwaun; Mountain Ash, etc. Ridd.

\section{Orobanchaceæ.}

\section{Orobanche, Linn. 321.}

1 199. major, Linn. Greater Broom-rape. Corn yr afr, Corn $y$ bwch, Paladr hïr, Orfangc.

Rare. Scarce. Native. Parasitic.

Swansea. Gutch. Phyt. I842. St. Fagans; Cadoxton Mill. Merthyr Dovan. J.S. Radyr, in profusion on broom, I907. M.A.D. and $V$. Penmaen ; Cowbridge. Ridd. 
1202. elatior, Sutton. Tall Broom-rape.

Rare. Scarce. Native. Parasitic.

Under the Castle walls at Penrice, and other places in the neighbourhood. Gutch. Phyt. I842. p. I43. Cwrt-yr-Ala. Mr.T. Chapman., J.S. Port Talbot. Ridd.

1204. Hederæ, Duby. Ivy Broom-rape.

Local. Frequent. Native. Parasitic.

Briton Ferry. Flower and Lecs. Phyt. I843. p.379. Oystermouth, Penrice, and other old castles in the neighbourhood of Swansea. L.W.D.Mat. Sully ! R. Woods. Barry Castle ; Gileston. D. Grey Friars, Cardiff ! J.S. (2). Barry Island ! H. Cardiff Castle grounds, since I897. $V$. On the ivy of the limestone rocks of the Gower coast ;-Three Cliffs Bay! Horton! Ramsgrove ! etc. Porthkerry! Ed. S. Cornelau; Llantwit Major cliff-. Ridd.

1 205. minor, Sm. Lesser Broom-rape.

Local. Frequent. Native? Parasitic.

Llangenydd; Porthcawl sands; Tythegston. Ridd. Very plentiful on clover-fields at Lunnon, Gower. $L$. Clover-field at Fairwater, since disappeared. $V$. and M.A.D. Swelclon Farm. Mr. Hedger Wallace.

\section{Lathræa, Linn. 322.}

1 207. Squamaria, Linn. Toothwort. Deintlys cenog.

Local. Frequent. Native. Parasitic.

Cooper's Fields, Coed-y-mwstwr, Llangrallo. J.S. Caerphilly ; Creigiau, Vale of Neath. D. Merthyr District. E. and $F$. Banks of feeder to Cardiff Docks. G.T. Coychurch, Talygarn. J.S. (2). Vale of Neath. $H$. Green Cwm (Parc le Bruce). L. Llandaff, Radyr. M.A.D. Pencoed. V. Creigiau. J. Ballinger. Whitchurch. sp.! Thorn Hill! Cardiff Castle Grounds ! The (?) against Glamorgan in Top. Bot. may be removed.

\section{Lentibularieæ.}

\section{Utricularia, Linn. 323.}

1208. vulgaris, Linn. Greater Bladderwort. Chwysigenwraidd cyffredin. Rare. Scarce. Native. Lacustral.

Oystermouth. E. Lees. Many places on Crymlyn Burrows ; Neath Canal. Flower and Lees. Phyt. I843. p. 379. Reens of Canton Common, Leckwith Common, Grangetown, etc. J.S. Grangetown Moors. $H$. West Moors, Cardiff. I. Almost, if not quite, extinct. $E d$.

1209. neglecta, Lehm. Grangetown. Hb. Cardiff. Ridd.

I have not been able to find any Glamorgan specimens of Utricularia in this Herbarium. Ed. 
1210. minor, Linn. Lesser Bladderwort. Chwysigenwraidd lleiaf.

Rare. Scarce (? extinct). Native. Lacustral.

Llandwr Marsh (? Landore). Gutch. Phyt. I842. Llyn-fach. J.S. Crumlin Bog. Hb. York Mus. Ridd.

There is only one modern record for any Utricularia in Glamorgan, that of Mr. Hallett, for the Grangetown Moors.

\section{Pinguicula, linn. 324.}

12 I3. vulgaris, Linn. Common Butterwort. Toddaidd melyn cyffredin, Golchwraidd.

Local. Frequent. Native. Uliginal.

St. Fagans, Rhondda Valley, Llynvi Valley, near Llangynwyd. J.S. Pontrhondda, Mardy, Clydach Vale, etc. Fl. Rhondda. Craig-y-Llyn. E. F. Linton. J. of B. 1892. p. 296. Hirwaun, common. W. Merthyr District. E. and F. Vale of Neath. G.T. and $H$. Pontneddfechan. M.A.D. Pontypridd, Aberdare Valley, the two Rhonddas, Moors W. of Neath River, Swansea Valley. T.H.T. Llandough, I84I. J.E. Ystradowen. M.A.D. Coedriglan. G.T. Twmpath, near Newton Down. Miss B. Treherbert! Glyncorwg. V. Gower; Ystalyfera; Cwm Parc; Graig Fawr; Aberdare. Ridd.

There is a doubtful record for No. 1216:-Llyngynwyd. J.S.

\section{Verbenaceæ.}

\section{Verbena, Linu. 325.}

1217. officinalis, Linn. Common Vervain. Cas gan gythraul, Llys yr hudol, Briw'r march, Derwen pendigaid, Derwen y ddaear.

Local. Frequent. Native. Viatical.

Too common in the lowlands for detailed record. In the neighbourhood of most villages in the Vale of Glamorgan and Gower. Absent from the uplands, with the exception of one record from Ystalyfera.

\section{Labiatæ.}

\section{Mentha. Linn. 326.}

I2 I 8. rotundifolia, Huds. Round-leaved Mint. Mintys lledcrynddail. Local. Frequent. Native. Inundatal, pratal, etc.

St. Donats Churchyard and thereabouts. Lightfoot. $J$. of $B$. 1905. p. 299. Briton Ferry. Flower and Lees. Phyt. I843. Banks of the Loughor, above Pontardulais. Motley. Penrice Castle. Dillwyn, L.W.D. Mat. St. Fagans, Tafts Well ! Pencoed. J.S. Pontrhondda, Blaenycwmy Fl. Rhondda. Rhubina; Maen 
llwyd. J.S. (2), Dunraven, Cefn On. V. Bishopston Valley! Ed. Penard; Neath; Kenfig; Caerphilly. Ridd. Mr. A. Bennett regards the Glamorgan plants as somewhat intermediate between typical rotundifolia and alopecuroides.

1220. Iongifolia, Huds. Common Horse Mint. Nintys bawm, Mintys Manaw, Mintys y meirch.

Rare. Scarce. Native. Inundatal.

By the mill going to St. Quintin's Castle, Cowbridge. Lightfoot. $J$. of B. 1905. p. 299. Banks of the Loughor, above Pontardulais. Motley, L.W.D.Mat. Near Pencoed; Moulton. J.S. Opposite Glyn Neath Station. E. F. Linton. J. of B. I892. p. 297. Peterston-super-Ely, I908. M.A.D. and V. Pendoylan! I907, Porthcawl; Aberdare; Cardiff. Ridd.

1221. viridis, Linn.= spicata, Linn. Spear Mint. Mintys Mair.

Local. Frequent. Alien. Viatical, etc.

Cardiff, Bridgend, etc. J.S. Penrhys Brook. Fl. Rhondda. Porthcawl. R. E. and F. Cundall. J. of B. 1902. p. 316. Near Park Mill. L. Mawdlam; Nottage; Cowbridge; Aberdare; Hirwaun; Penllergare. Ridd.

1222. piperita, Linn. Peppermint. Poethlyslyn.

Local. Frequent. Native. Paludal, inundatal.

Ditch near Rutland Place, Swansea. B.G. (of course, now extinct). Three or four miles above Pontardulais. Motley, L.W.D. Mat. St. Fagans. J.S. Porthcawl. R. E. and F. Cundall. J. of $B$. I902. Southerndown. $V$. Cwrt-yr-Ala ! Llantwit Major ! Taffs Well! Burry! Burry Pill! Llangenydd! Quoity Green! Ed. Ystalyfera; Kenfig; Monknash; Aberthin ; Ystradowen ; Llandough; Peterston; Hirwaun; Oxwich; and Aberdare. Ridd.

1224. hirsuta, Huds. Hairy Water Mint. Mintys blewog.

Common. Abundant. Native. Paludal.

1225. Sativa, Linn. Marsh Whorled Mint. Mintys troellaidd.

Local. Frequent. Native. Paludal, inundatal.

Some of the records sent in under 1224 are almost certainly for this type. Penarth ! Burry Green ! Ed. Park Mill; Oxwich ; Killay; Whitford Burrows; Aberdare ; Hirwaun ; Perddyn Glen ; Port Talbot. Ridd.

1 226. rubra, Sm. Tall Red Mint. Mintys coch. Rare. Scarce. Native. Paludal, inundatal.

Burry ! ! Ed. River below and road above Hirwaun. Ridd.

1 230. arvensis, Linn. Corn Mint. Mintys ar-dir.

Common. Abundant. Native. Agrestal, inundatal.

The absence of records from the Loughor Valley is to be noted.

c. agrestis (Sole) and f. parietariafolia (Beck). Aberdare. Ridd. 
1231. Pulegium, Linn. Penny-royal. Brymlys, Colyddlys, Llyrcadys, Llysiau pwding.

Local. Frequent. Native (? always). Pascual, etc.

At Pyle, by roadside to Cornelau. Motley, L.W.D.Mat. Pencoed, Penprisc. J.S. Dinas Powis! abundant since r905; Reynoldstone ! I908. Pitton Green ! Oxwich Green ! Ed. Nottage. E.S.M., Ridd.

\section{Lycopus, Linn. 327 .}

1232. europæus, Linn. Water Horehound. Llys-yr-hudolesau, Llys-ysipsiwn.

Common. Abundant. Native. Paludal, inundatal. Rather thinly distributed all over the county.

Origanum, Linn, 328.

1233. vulgare, Linn. Common Marjoram. Mesuriad cyffredin, Penrudd, Mintys y creigiau.

Local. Frequent. Native. Rupestral, etc.

Frequent on the limestones of the lowlands from Lavernock to Rhossili. Very numerous records from all such districts in the county. No records from the valley of the Loughor. Rare (or absent) on the coal measures and in the uplands.

\section{Thymus, Linn. 329 .}

1234. Serpyllum, Fr. Wild Thyme. Gruwlys gwyllt.

Common. Abundant. Native. Ericetal, pascual, etc.

Possibly rare or scarce in certain districts. In Fl. Rhondda the only locality given is Hafod (Storrie); although Storrie in the Flora of Cardiff does not record this. Some of the records, too, may refer to 1235 .

1235. Chamadrys, Fr. Larger Wild Thyme.

This segregate, cut off from the preceding species, is on record as follows:- "Thymus Chamcedrys was the segregate I came across in Gower." E. F. Linton. J. of B. I892. p. 296. Mumbles; Oxwich to Port Eynon; Rhossili ; Cornelau ; Barry Island. Ridd. Port Eynon to Oxwich! I908, where, however, there are intermediates serving to connect it with 1234. These forms should be tested experimentally. Ed.

\section{Calamintha, Lam. 330 .}

1236. Clinopodium, Spenn.= Clinopodium vulgare, Linn. Wilk Basil. Breninllys gwyllt.

Local. Abundant. Native. Septal, etc.

Localities too numerous for record in the lowlands from Ruperra to Rhossili. Other localities as follows:-Hirwaun, Aberdare, Merthyr. W. Pontypridd ! Caerphilly ! Cefn On ! Ed. Bodringallt, Cymmer. Fl. Rhondda. 
1237. arvensis, Lam= Acinos, Clairv. Basil Thyme.

Rare. Frequent. Native and alien. Rupestral, viatical, etc.

Swansea. Gutch. Phyt. I 842. p. I 44. Near Pitton; Bishopston Valley. L. Melingriffith Works. V. Taffs Well; 1905 and subsequent years! Horton! Port Eynon! Ed. Pwlldu to Penard; Worms Head; Aberafan Burrows; Porthcawl; Barry. Ridd. Clearly native in Gower.

The records for 1238 ;-(I) by Woods, Caerphilly. Phyt. 1850. p. I06I; and (2) in Top. Bot. Edit.2. Supp. must be excluded.

1239. officinalis, Moench $=$ Clinopodium Calamintha, o. Kuntze.

Common Calamint. Erbin cyffredin, Mintys y gath.

Local. Scarce. Native. Septal, rupestral, etc.

Singleton. Gutch. Phyt. I842. p. I 44. St. Fagans ! V. Merthyr District. E. and F. Michaelstone-le-pit, several habitats ! Barry Island ! St. Quintin's Castle, Cowbridge ! Porthcawl ! Bishopston, I908! Swanbridge! Ed. Penmaen; S. Cornelau ; Ewenny; Sully. Ridd.

No. I 24 I occurs occasionally as an outcast.

\section{Salvia, Linn. 332.}

1 242. Verbenaca, Linn. Wild English Clary. Torfagl, Golwg Crist, Clais y moch.

Local. Frequent. Native and alien. Pascual, viatical, etc.

Cardiff, Penarth, and Barry. J.S. Bodringallt, Blaenrhondda. Fl. Rhondda. Llanbleiddian! J.S. (2) and W. Pettigrew. St. Fagans. M.A.D. St. Quintin's Castle, Cowbridge! Rev. W. F. Evans. Newton Nottage! Llantwit Major! Merthyr Mawr! Horton! Port Eynon! Ed. Oxwich; Paviland; Vernon Park; Aberafan; Port Talbot; Porthcawl; S. ${ }_{2}$ Cornelau ; Aberdare. Ridd.

No. I 243 and S. verticillata $L$. are excluded, as neither is successful in the struggle for existence with their competitors. S. verticillata seeds freely, but dies out quickly.

\section{Nepeta, Linn. 333 .}

1244. Cataria, Linn. Cat-mint. Mintys y gath.

Local. Scarce. Native (? always). Viatical, agrestal.

Hedges near Swansea. N.S.G. A doubtful record. Caerphilly ? probably erroneous, credited to this species by Storrie and Riddelsdell, although Woods plainly refers to Calamintha Nepeta. Phyt. 1850. p. I06I. Kenfig! J.S. (2) and $H$. Not uncommon near Hunts and Hael, near Pwlldu. L. Llancarfan, 1891 and 1892 ! Newton Nottage, I89I and I892! Taffs Well, I905 and for many preceding years! Leys, 1905, very abundant ; scarce in 1907 ! Cheriton, 1908 ! Ed. Frequent in Gower; Southerndown; Barry; Monknash ; Aberdare. Ridd. 
1 245. Glechoma, Benth. Ground-Ivy. Eidral, Bydiawg, neu Beidiawg lâs.

Common. Abundant. Native. Septal, sylvestral, etc.

\section{Scutellaria, Linn. 334 .}

I 246. galericulata, Linn. Common Skull-cap. Cyccyllog mwyaf. Common. Abundant. Native. Paludal.

Records from all parts of Glamorgan, though the plant is certainly not what is generally described as common. Very abundant in certain areas.

1247. minor, Huds. Lesser Skull-cap. Cyccyllog lleiaf.

Local. Frequent. Native. Uliginal.

Penllergare, Drymma, Neath Valley, generally more plentiful than 1246. Gutch. Phyt. 1842. New Cemetery, Cardiff; Llanishen; Rhymney Valley; Llangynwyd. J.S. Cefn On. J.S. (2). Blaenrhondda, Aberllechau. Fl. Rhondda. Hirwaun. W. Merthyr district. $E$. and $F$. Mynydd y Glaw; the Garth ! $V$. Llanishen. $D$. Taffs Well ! $H$. Kittle. L. Radyr. M.A.D. Onllwyn; Maesteg. T.H.T. Sully Moor! Hensol ! Pontypridd ! Mead Moor! Cefn Bryn! Ed. Loughor Down; Llynfach. Ridd. Not so abundant as 1246 , but perhaps quite as widely distributed.

\section{Prunella, Linn. 335 .}

I 248, vulgaris, Linn. Self-heal. Meddyges las, neu Craith un-nos. Common. Abundant. Native. Pascual.

\section{Marrubium, Linn. 337 .}

I 250. vulgare, Linn. White Horehound. Llwyd y cwn, Perchwerwyn, Marddynad, neu Marddanadlen bêr.

Local. Frequent. Native. Viatical, glareal.

Port Eynon ! Westcombe. Phyt. 1844. p. 780. Worms Head, July, 1834. Nat.Hb. Ely, St. Fagans, St. Hilary, Barry ! J.S. Margam Burrows! Marshall and Shoolbred. J. of B. 1902. p. 248. Sker. R. E. and F. Cundall. J. of B. I902. Southerndown! I., Miss B., M.A.D. and V. St. Hilary. G.T. Pennard Cliffs. L. Barry! I891. U.C.Hb. Culver Hole! Horton! Cheriton! Llanmadoc ! and other places in Gower! Ed. Aberdare; Pennard to Llanmadoc; Ridd. Certainly native in Gower; of doubtful status elsewhere. $E d$.

Stachys, Linn. 338 .

125I. Betonica, Benth. = officinalis, Franchet. Wood Betony. Cribau St. Ffraid, Llys dwyfawg, Dannogen.

Common. Abundant. Native. Sylvestral, septal, etc. Ascends to 1500 feet on Craig Fawr and Craig-y-Llyn.

1253. palustris, Linn. Marsh Woundwort. Briwlys y gors, Briwlys y taiog.

Common. Abundant. Native. Paludal. 
$\times$ sylvatica (ambigua, Sm.). Kilvey Hill. Gutch. Phyt. 1842. p. I44. Penlline! U.C.Hb. Ed. Nicholaston; Neath; Caerphilly. Ridd.

1254. sylvatica, Linn. Hedge Woundwort. Briwlys y coedwig.

Common. Abundant. Native. Sylvestral.

1 255. arvensis, Linn. Corn Woundwort. Briwlys yr âr.

Local. Abundant. Native. Agrestal.

Mumbles Road. Gutch. Phyt. 1842. Penylan, Llanishen, Penarth. J.S. Bodringallt. $W$. Southerndown. Miss B. Penarth. H. Merthyr District. E. and F. Park Mill, etc., Gower. L. Lavernock ! Dinas Powis! Kenfig! Llantwit Major ! Creigiau ! Port Eynon! and Oxwich! Ed. Gowerton; Kilvey Hill; Graigafan; PorthcawI; Ystradowen; St. Athans; Aberdare. Ridd. All over the county, I believe, on the arable lands.

\section{Galeopsis, Linn. 339.}

1258. angustifolia, Ehrh. Narrow-leaved Hemp-Nettle.

Local. Frequent. Native. Viatical, etc.

Common around Swansea. Gutch. Phyt. 1842. Penarth ! Sully ! Bonvilstone, Pencoed. J.S. Aberdare and Vale of Neath? WV. Llantwit Major. D. Not common (in Gower). L. Gileston. M.A.D. Southerndown, $V$. Leys ! Pwlldu ! in each case on "hurricane beaches." Dinas Powis ! Cornfield near Mead Moor, Gower! Ed. Kenfig; Porthcawl; Ridd.

I 260. versicolor, Curt. Large-flowered Hemp-Nettle.

Rare. Scarce. Native? Agrestal.

Gowerton to Penclawdd. E. F. Linton. J. of B. I892. p. 296. Near Aberdare and Mountain Ash. J.S. Merthyr Mawr? Miss B.

I 26 I. Tetrahit, Linn. Common Hemp-nettle. Penboeth gyffredin.

Common. Abundant. Native. Septal, agrestal, etc.

b. bifida (Boenn.) Aberdare; Welsh St. Donats; Peterston ; Merthyr Vale. Ridd.

\section{Leonurus, Linn. 340.}

1 262. Cardiaca, Linn. Motherwort. Mamlys, Llys y fammog.

Rare. Scarce. Alien. Viatical.

Pyle and Kenfig. Motley, L.W.D.Mat. St. Hilary. J.S. and Rev. W. F.Evans. Taffs Well. U.C.Hb., Mr.Chapman. S. Cornelau; Aberthin. Ridd.

\section{Lamium, Linn. 341.}

1263. amplexicaule, Linn. Henbit. Mardlanadlen goch cylchddail. Rare. Frequent? Native. Agrestal.

Penarth; St. Athans. J.S. Pant yr eisteddfa. Fl. Rhondda. Between Porthcawl and Newton. R. E. and F. Cundall. J. of B. 
1902. p. 316. Newton; Swanbridge. $V$. Gower, Mawdlam; Dinas Powis. Ridd.

No. I 264 is excluded, in the absence of confirmation of Storrie's records.

\section{5. hybridum, Vill.}

Rare, Scarce. Native. Viatical.

Near Swansea. L.W.D.Mat. Penarth Ferry; near Barry Mill. J.S. Penarth Head ! few specimens for two or three years in succession; Swanbridge! very scarce. Ed. Kenfig; Margam; Port Talbot; Porthcawl to S. Cornelau; Cog ; frequent in Gower; Ridd.

1 266. purpureum, Linn. Red Dead-nettle. Marddanadlen goch, Dynad, neu Danadlen farw goch.

Common. Abundant. Native. Agrestal.

b. decipiens, Sonder. Gowerton to Penclawdd. E. F. Linton. $J$. of B. I892. p. 297. Oxwich ; Rhossili ; Llangenydd ; Glyn Neath ; Marcross ; Ystradowen ; Llwydcoed. Ridd. In Lond. Cat., Ioth Edit., a distinction is made between this variety and the hybrid hybridum $\times$ purpureum.

No. 1267 is not infrequent as an escape, but never really becomes naturalised.

I 268. album, Linn. White Dead-nettle. Marddanadlen wen.

Local. Frequent. Native, or denizen. Viatical, etc.

Records from all parts of the county ; too numerous for citation.

1269. Galeobdolon, Crantz. Yellow Archangel. Danadlen ddail.

Local. Abundant. Native. Sylvestral, septal.

Too common in all parts of the Eastern half of the county for citation of the records; local in the Western half, as shown by the following records:--Penllergare. Gutch. Phyt. I842. Pantyffynon to Pontardulais; Ystalyfera ; Upper Neath Valley; Graigafan. Ridd. No record from Gower.

\section{Ballota, Linn. 342.}

1270. nigra, Linn. Black Horehound. Marddanadlen ddu.

Local. Abundant. Native. Viatical.

Too common in the Eastern half of the County for records to be regularly made; more local in the Western half. The records for Gower are:-Not common ; Pennard cliffs ; Mewslade. L. Llangenydd. Ridd.

\section{Teucrium, Linn. 343.}

1274. Scorodonia, Linn. Wood Sage. Triagl y Cymro, Chwerwlys yr eithin, Chwerwyn y twyn, Saets gwyllt.

Common. Abundant. Native. Septal, etc. 
Ajuga, Linn. 344.

1275. reptans, Linn. Bugle. Golchenid cyffredin, Glesyn y coed. Common. Abundant. Native. Pratal, sylvestral, etc.

\section{6o. Plantagineæ.}

\section{Plantago, Linn. 345 .}

1278. major, Linn. Greater Plantain. Llyriad mwyaf, Henllydan y ffordd.

Common. Abundant. Native. Viatical, etc.

A very dwarf form, probably the var, microstachya, Wallr., occurs on the S. shore of Kenfig Pool. Under different conditions of nutrition this type would probably give rise to normal plants. The monstrous form with large branched spikes occurs at Port Eynon. The form intermedia (Gilib.) is, according to Riddelsdell, of frequent occurrence.

1279. media, Linn. Hoary Plantain.

Local. Frequent. Native. Pascual.

Frequent on the Lias near the coast. Penarth! Sully ! etc., to Southerndown ! J.S. Swansea. Gutch. Phyt. 1842. Penrhys. $F l$. Rhondda. Hirwaun and Aberdare. $W$. Cogan. V. Ystradowen! Ed. Penmaen; Craig Llanishen. Ridd.

1280. lanceolata, Linn. Ribwort Plantain. Llyriad Llwynhidydd, Llwyn y neidr, Pennau'r gwyr.

Common. Abundant. Native. Pascual, pratal, etc.

1281. maritima, Linn. Sea Plantain. Bara can y defaid, Llyriad y mor, Gwerog, Man y don.

Local. Abundant. Native. Littoral.

All round the coast, and especially abundant on salt muds, as in the estuaries of the Rhymney, Taff, and Ely.

1282. Coronopus, Linn. Buck's-horn Plantain. Llyriad Corn y Carw, Llys Efa.

Common. Abundant. Native. Littoral.

Two inland stations on record :-S. Cornelau; Caerphilly. Ridd.

\section{Littorella, Berg. 346.}

1284. juncea, Berg. Plantain Shore-weed. Beisdonell merllyn.

Local. Abundant. Native. Lacustral, inundatal.

Llyn-fawr. J.S. and Ed. 1892, U.C.Hb. Llyn-fach ! but extinct apparently by 1905. Kenfig Pool! I 897 and very abundant ever since. Welsh St. Donats ! Pendoylan ! Broad Pool, Gower ! Ed. Hirwaun Pond; extinct in Llyn fawr. $W$. Pendoylan. I., M.A.D. and V. Penard Burrows; Cefn Bryn. Ridd. 


\section{NOTE ON THE PREPARATION OF SECTION IV.}

Two additional correspondents have furnished records for Section IV., viz., Miss P. Simons, of Port Eynon, and Mr. Walter Cook, M.S.A., of Bridgend. Their records are denoted respectively by the abbreviations $M i$ iss $S$. and $W . C$.

Further study of the "critical " forms of this Section is still desirable.

\section{I. Illecebraceæ.}

\section{Scleranthus, Linn. 350 .}

1290. annuus, Linn. Common Knawel. Dinodd blynyddawl.

Local. Frequent? Native? Glareal.

In the absence of any personal knowledge of the occurrence of this plant in Glamorgan, the editor inserts all the records available, although several of these are almost certainly erroneous.

Sandy places, all over the district? J.S. Frequent in Rhondda. Fl. Rhondda. Common at Southerndown. Miss B. Porthcawl. W.C. and $H$. Sully; Barry. $H$. Port Talbot; Aberafan; Hirwaun ; Aberdare. Ridd.

\section{Chenopodiaceæ.}

\section{Chenopodium, Linn. 352.}

1294. polyspermum, Linn. Many-seeded Goosefoot.

Local. Frequent. Colonist. Agrestal, viatical.

G.W.R. embankment; near Cardiff Docks and Penarth. J.S. Near Ystrad gasworks. Fl. Rhondda. Cathays Park. V. Cwrt-y-fil, Penarth, 1905. Very abundant. Near Southerndown, I905. Ed. Port Talbot Docks, Ridd.

Vulvaria, Linn. Stinking Goosefoot.

Rare. Scarce? Alien? Viatical.

Two records only, both probably referring to introduced plants.

Near Sully Island. J.S. Port Talbot. Ridd.

TRANS. CARD. NAT. SOC.-SUPPLEMENT. 
I 296. album, Linn. White Goosefoot. Gwydd-droed gwynaidd. Common. Abundant. Native. Agrestal.

Often a very troublesome weed in the Vale of Glamorgan.

a. incanum, Moq. Llantwit Major, I905. Welsh St. Donats to St. Hilary. Ed. Gower; Port Talbot. Ridd.

b. viride, Syme. Near Singleton. Gutch. Phyt. 1842. p. I 44 . Penarth, I905; Llantwit Major, 1905. Ed. Port Talbot; Aberdare. Ridd.

c. viridescens, St. Am. Port Talbot; Barry Island; Aberdare. Ridd.

murale, Linn.

Alien.

At Leckwith. V. and M.A.D. Port Talbot. Ridd.

1302. rubrum, Linn. Many-clustered Goosefoot. Gwydd droed rhuddawg.

Local. Frequent to abundant. Native. Littoral and viatical.

Near Singleton marsh. Gutch. Phyt. I842. p. I44. Kenfig Pool. Mr. Motley. L.W.D. Mat. About Cardiff and Penarth. J.S. Tylacoch. Fl. Rhondda. Port Talbot; Porthcawl; Ogmore estuary; Aberdare, Ridd. Cathays Park; Ely. V. Penarth. H. Very abundant near the shore at Whitford Burrows, 1908. Ed.

1304. glaucum, Linn. Oak-leaved Goosefoot. Derwen Caersalem.

Rare. Frequent. Alien. Viatical.

St. Helens, Swansea. Gutch. Phyt. I842. p. I44. Penarth. J.S. Penarth Dock, 1907 to I909; abundant. Ed. Port Talbot. Ridd.

1305. Bonus-Henricus, Linn. Allgood. Sawdl y crydd, Llys y gwrda. Local. Frequent. Denizen. Viatical.

The habitats of this species are almost invariably close to houses; this may be due either to its nitrophilous character, or to its lost reputation as a valuable vegetable, or to both.

Worms Head; Neath. Gutch. Phyt. I842. p. I44. Allen's Bank, St. Athan; Bridgend, \&c. J.S. Southerndown. Miss B. Overton! Miss S. Newton, Porthcawl. W.C. Taffs Well. M.A.D. Rhubina. $V$. Llantwit Major. J.S. (2), Riverside, Cardiff. $H$. Ystalyfera; Kenfig; Aberdare; Welsh St. Donats. Ridd. Merthyr district. E. and F. Cog, Sully; Port Eynon, and other places in Gower. Ed.

\section{Beta, Linn. 353 .}

1306. maritima, Linn. Sea Beet. Melged arfor.

Local. Abundant. Native. Littoral.

Confined to the coast; but fairly well distributed from Cardiff to the Worms Head. 


\section{Atriplex, Linn. 354.}

1307. littoralis, Linn. Grass-leaved Sea Orache. Llygwyn arfor.

Local. Frequent. Native. Littoral.

Swansea. Westcombe. Phyt. 1844. p. 780. Penarth! Barry! Aberthaw; \&c. J.S. Oxwich. Miss S. Penarth Ferry ! $V$. Port Talbot. Ridd. Ely and Taff estuaries; Sully. Ed.

1308. patula, Linn. Narrow-leaved Orache. Llygwyn tryfal.

Local. Frequent. Native. Viatical, agrestal.

Records for the aggregate species are as follows:-Between the Ferry and Port Tennant. Gutch. Phyt. 1842. p. I45. Cardiff and Penarth. J.S. Oxwich and Horton. Miss S. Merthyr district. $E$. and $F$. Penarth Ferry. M.A.D. Worms Head; Neath; Aberdare. Ridd. (for type only ?).

b. erecta, Huds. Port Talbot; S. Cornelau; Merthyr Dyfan; Aberdare; Cardiff. Ridd. Near Llandough railway platform. Ed.

c. angustifolia (Sm.) Singleton and Kilvey Hill. Gutch. Phyt. I842. p. I45. Gower; Neath; Port Talbot; Aberdare ; Cardiff ; Llandaff; St. Fagans; Peterston; Machen. Ridd. Llantwit Major. $E d$.

\section{9. hastata, Linn.}

Local. Frequent. Native. Littoral.

Langland Bay; Port Talbot; Ogmore estuary; Fairwater ; Cardiff; Aberdare. Ridd. Ely and Taff estuaries. Ed.

\section{310 . deltoidea, Bab.}

Local. Frequent. Native. Littoral.

Near Crumlin Bog; Neath ; Port Talbot; Cardiff ; Aberdare ; Swanbridge; Ely. Ridd. Penarth and Ely estuary. Ed.

\section{3 I . Babingtonii, Woods.}

Local. Frequent. Native. Littoral.

Sully! and Barry! Woods. Phyt. I850. p. I061. Porthcawl. R. E. and F. Cundall. J. of B. 1902. p. 316. Barry; Aberthaw; \&c. J.S. Penarth Ferry!! V. Oxwich; Penclawdd; Whitford Burrows; Port Talbot; Ogmore Estuary; Cardiff. Ridd. Ely and Taff estuaries. Ed.

\section{I2. laciniata, Linn.}

The only records for this species as a native are due to the Revs. H. J. Riddelsdell and WV. Moyle Rogers. Langland Bay; Penclawdd; Crumlin Burrows; Jersey Marine; Port Talbot and Porthcawl.

I3 3. portulacoides, Linn. Sea Purslane. Eurllys, Llygwyn llyswyddaidd.

Local. Abundant. Native. Littoral. 
Occurs on all the muddy salt-marshes of our estuaries from the Taff to the Loughor. It specially affects the steep mucldy banks of the small drainage channels which are so characteristic a feature of most of our salt-marshes.

\section{Salicornia, Linn. 355 .}

1315. herbacea, Linn. Common Marsh Samphire. Llyrlys llysieuaidd. Local. Abundant. Native. Littoral.

Occurs on all the muddy salt-marshes of the county, and is very variable. Four or five forms may be readily distinguished, and Mr. Riddelsdell records the occurrence in the county of $S$ appressa, Dum., S. pusilla, Woods, S. stricta, Dum., S. procumbens, Sm., S. ramosissima, Woods, and S. intermedia, Woods. The testing of these various forms, by the method of "pedigree cultures," on different soils, would probably lead to interesting results.

\section{Suæda, Forsk. $35^{6}$.}

I31 8. fruticosa, Forsk. Shrubby Seablite.

Rare. Scarce. Native. Littoral.

Port Tennant. Gutch. Phyt. I842. p. I44. Flat Holme; Cogan Pill ! J.S. This species occurred for years-I890 to I905and probably still occurs, growing between the stones protecting the banks of the River Ely, near the old ferry. $E d$.

1319. maritima, Dum. Annual Seablite.

Local. Abundant. Native. Littoral.

On all the muddy salt-marshes.

\section{Salsola, Linn. 357 .}

I320. Kali, Linn. Prickly Saltwort. Hel-lys yspigawg.

Local. Frequent. Native. Littoral.

Occurs on the sands near high-water mark from Barry to Port Eynon, and probably to Whitford also.

\section{Polygonaceæ.}

Polygonum, Linn. $35^{8}$.

1321. Convolvulus, Linn. Climbing Buckwheat. Yttag, Taglys yr yd, Perthlys.

Common. Abundant. Native. Agrestal.

No record from the Loughor Valley.

b. subalatum, V. Hall. Oxwich ; Langland Bay; Port Talbot ; Barry; Canton; Aberdare, Ridd. Swanbridge. Ed.

Mr. Hallett records $P$. dumetorum, Linn., as a troublesome garden weed at the Spinney, Sully. 
1323. aviculare, Linn. Common Knotgrass. Canclwm, Berwr yr iâr, Gwaedlys, Clymmog.

Common. Abundant. Native. Agrestal, viatical, glareal.

This polymorphic species needs thorough investigation by modern methods. Mr. Riddelsdell records the occurrence of six varieties in the county, viz.:-vars, agrestinum (Jord.), vulgatum, Syme, arenastrum (Bor.), microspermum (Jord.), rurivagum (Jord.), and littorale (Link).

1324. Raii, Bab. Ray's Knotgrass.

Rare. Scarce. Native. Littoral.

Neàr Salt House Point ; near eastern pier. Gutch. Phyt. I842. pp. I44, 205. Neath. Flower. Ridd. in F. of G. Admitted to Top. Bot. apparently on the evidence of Flower's specimen. Storrie's records clearly refer to littoral forms of the preceding species. Newton. Miss B. Worms Head; Oxwich ! Horton ! Miss S. Aberthaw. T.H.T. Port Eynon sands and Oxwich sands, but very scarce. Ed.

The records for $1325, P$. maritimum, clearly refer to 1324 .

1326. Hydropiper, Linn. Water Pepper. Tinboeth, Llys y dîn. Common. Abundant. Native. Inundatal, paludal.

1327. minus, Huds. Small Persicaria. Clymmog bychan, Treigledlys. Rare. Scarce? Native? Inundatal.

Near the Ferry, Swansea. Gutch. Phyt. I842. p. I44. Port Talbot. Ridd.

mite, Schrank. Lax-flowered Persicaria.

The following two old doubtful records need modern confirmation.

Swansea. Gutch. Phyt. 1842. p. I 44. About Neath and Fabian's Bay. Flower and Lees. Phyt. i843. p. 380.

1329. Persicaria, Linn. Spotted Persicaria. Elinog gôch.

Common. Abundant. Native. Agrestal, viatical, inundatal.

1330. lapathifolium, Linn. Glandular Persicaria. Costog y dom, Llys y dom.

Local. Abundant. Native. Agrestal, inundatal.

Although not common, too widely distributed for the citation of the records. Abundant in the valley of the Ddaw, for which district alone Mr. Riddelsdell gives no records. Welsh St. Donats ! St. Hilary ! Lavernock ! Dinas Powys !

\section{1. maculatum, Trim. \& Dyer.}

Rare. Scarce? Native. Viatical.

Port Talbot; Aberdare; Cardiff Docks. Ridd. Railway bank near Riverside; Penarth. $H$. Probably almost always an alien.

1332. amphibium, Linn. Amphibious Bistort. Canwraidd goch.

Common. Abundant. Native. Lacustral, inundatal, even viatical. 
1333. Bistorta, Linn. Common Bistort. Llys y neidr, Mon. Blodau powdr.

Local. Abundant. Native. Pratal.

About Swansea. Gutch. Phyt. I842. p. I44. Between Pencoed and Llantrisant. Marshall and Shoolbred. J. of B. 1902. p. 250. Greenmeadow; St. Fagans! Hensol, etc. J.S. Penrhys. Fl. Rhondda. Ogmore. Miss B. Ilston, Gower. T.H.T. Merthyr district. E. and F. Bridgend ! Llangewydd. W.C. Schwyl, Ewenny. V., W.C., and M.A.D. Vale of Neath. $H$. Near Maesmawr, on the S. side of the Llantrisant Road, i833. J.E. Gorseinon. Swan. Sci. Soc. Proc. I895-6. p. 75. Penrice; Pantyffynon; Aberpergwm ; Aberdare ; Penydarren ; Glyn Corwg; Whitchurch ; Tongwynlais. Ridd. Ystradowen; Welsh St. Donats; Draethen. Ed. Sometimes introduced.

Rumex, Linn. 360 .

I337. conglomeratus, Murr. Sharp Dock. Trython, Tafolen Mair, Chwysoglen.

Common. Abundant. Native. Inundatal, viatical.

I339. sanguineus, Linn. Bloody-veined Dock. Tafolen goch, Tafolen waedlyd.

Common. Abundant. Native. Pratal, viatical, \&c.

The common form is the var. viridis (Sibth.). Records for the type are rare and doubtful, with one exception, viz. -Neath. Rev. W. Moyle Rogers, Ridd.

maritimus, Linn. Golden Dock.

Rare. Scarce. Alien. Viatical.

Port Eynon?-a record taken from the Swansea Guide. L.W.D. Mat. Barry, ballast. Ed. Cardiff, native. Ridd. The species would not have been included at all, but that it seemed desirable to call attention to its status as an alien.

pulcher, Linn. Fiddle Dock.

Rare. Scarce. Alien. Viatical.

E. Moors, Cardiff. J.S. Cathays Park, Cardiff, I903. V. Southerndown. Miss B. Porthcawl, 1905 to 1909. Ed. Loughor; Port Talbot. Ridd. Almost certainly an alien in all its localities.

1343. obtusifolius, Linn. Broad-leaved Dock. Tafolen gyffredin, Tafolen lydanddail.

Common. Abundant. Native. Pratal, viatical, etc.

1344. crispus, Linn. Curled Dock. Tafolen grych.

Common. Abundant. Native. Pratal, viatical.

var. trigranulatus, Syme. Widely distributed, according to Riddelsdell.

$\times$ obtusifolius $=R$. acutus, Linn. Pontardulais ; Graigafan ; Cowbridge. Ridd. Cogan Hall, I905 and I907; Dinas Powys, I905; Llandough, 1907. Ed. 
1346. Hydrolapathum, Huds. Great Water Dock. Tafolen y dwr. Local. Abundant. Native. Paludal.

Crumlyn Bog. Westcombe. Phyt. 1844. p. 780. Penllergare! G.T. Oxwich Marsh! Miss S. Park Mill! Rhosili ; Llangenydd; Jersey Marine; Aberdylais; Neath Abbey; Margam to Aberafan Moors. Ridd. Flemingston Moor and Penmark in the rivers Ddaw, Waycock, and Keyson; Kenfig Pool ; Hensol Ponds ; and marshes alongside the River Ely. Ed.

1348. Acetosa, Linn. Common Sorrel. Suran y waun, Suran y cwn, Suran y frân.

Common. Abundant. Native. Pratal, etc.

1350. Acetosella, Linn. Sheep's Sorrel. Dringol, Drigon, Suran yr yd. Common. Abundant. Native. Pascual, ericetal, etc.

\section{Thymelæaceæ.}

Daphne, Linn. 363.

1354. Laureola, Linn. Spurge Laurel. Clust yr Ewig.

Local. Frequent. Native. Sylvestral.

Cogan Pill ! Penarth! Porthkerry! Gigman Bridge! Llantwit Major, etc. J.S. Cardiff. R. W. Rickards. J. of B. I884. p. 26I. Monknash and Dunraven. Miss B. St. Hilary. G.T. Cwm George! Mrs. Holme-Russell. Llandaff. M.A.D. Llandough, on side of road leading to Sully, I83r. J.E. Cwrt-yr-Ala! Castell Coch. $H$. Lavernock! and many other places. Ed. Merthyr Mawr. Ridd. Fairwater. I. Its absence from Top. Bot. is remarkable.

\section{Loranthaceæ.}

Viscum, Linn. 365.

I356. album, Linn. Mistletoe. Uchelawg, Uchelfar, Uchelwydd, Prenawyr, Gwysglys, Heonllys, Darllys awelfar.

Rare. Scarce. Native. Parasitic.

Crockherbtown; St. Fagans, etc. J.S. Cardiff to Llantrisant. Bot. Rec. Chub Report. I873. Ridd. Penllergare. G.T. Sully, on aspen. $H$.

\section{Euphorbiaceæ.}

Euphorbia, Linn. 367 .

1358. Peplis, Linn. Purple Spurge.

Probably extinct, but should again be searched for. Two interesting records, the second a comparatively recent one. 
Plentiful near Porthcawl about 1836 , but extinct in 1848 . Motley. L.W.D. Mat. p. 32. "Some years ago I found E. Peplis here, but so far this summer (I909) have failed to find a plant. Possibly extinct." Miss Simons, Port Eynon.

1359. Helioscopia, Linn. Sun Spurge. Llaeth ysgyfarnog.

Common. Abundant. Native. Agrestal.

I360. platyphyllos, Linn. Broad-leaved Warted Spurge.

Rare. Frequent. Colonist. Agrestal.

Cliffs, near Lavernock. J.S. Corn field, Llandough; noted in abundance from 1899 to 1907. Perhaps, nevertheless, scarcely deserving inclusion. $E d$.

1366. amygdaloides, Linn. Wood Spurge.

Local. Abundant. Native. Sylvestral.

Swansea. Flower and Lees. Phyt. 1843. p. 380. Cogan! Cwm George! Llandaff; Duffryn Golach, etc. J.S. Merthyr Mawr. Miss B. Oxwich. Miss S. Merthyr district. E. and F. Radyr. M.A.D. and V. Cwrt-yr-Ala ! very abundant. $H$. Park Mill ; Port Talbot; Taffs Well; Ystradowen. Ridd.

1369. Paralias, Linn. Sea Spurge. Llys y famaeth.

Local. Abundant. Native. Glareal, littoral.

Found in all suitable spots on the coast from Penarth to Whitford.

1370. portlandica, Linn. Portland Spurge. Flamgoed y morgreigiau.

Local. Abundant. Native. Rupestral, littoral.

Abundant in suitable places on the coast from Whitford to Porthcawl. No trustworthy records for the coast from Porthcawl to Cardiff.

Plants intermediate between $\mathrm{I} 369$ and I 370 are not infrequent. Mr. Riddelsdell has also recognised such plants.

1371. Peplus, Linn. Petty Spurge. Fflamgoed fechan, Llaeth y cythraul. Common. Abundant. Native. Agrestal.

1372. exigua, Linn. Dwarf Spurge. Fflamgoed eiddil flaenfain, Fflamgoed bach yr yd.

Local. Frequent. Native. Agrestal, etc.

Sketty. Gutch. Phyt. I842, p. I45. Penarth! Llandaff, etc. J.S. Cardiff. Rickards. J. of B. I884. p. 26I. Southerndown. Miss B. and $V$. Widespread in Gower! Miss $S$. Newton Nottage ; Cold Knap. M.A.D. Porthcawl ; Port Talbot; Monknash. Ridd. Very frequent in the Vale of Glamorgan. $E d$.

No. 1373 is excluded.

\section{Mercurialis, Linn. 369.}

1375. perennis, Linn. Perennial Dog's Mercury. Clais yr hudd parhäus, Bresych y cwn, Cwlwm yr asgwrn.

Common. Abundant. Native. Septal, sylvestral.

annua, Linn. This alien occurs quite frequently and sometimes persists for several years in the same locality. 


\section{I. Urticaceæ.}

\section{Ulmus, Linn. 370 .}

1377. montana, Stokes. Broad-leaved Elm. Llywfanen lydanddail.

Common. Abundant. Native. Sylvestral.

"Am inclined to think it native; it occurs sporadically in mountain glens, in Vale of Neath and Swansea Valley." T.H.T. A very large wych elm at Cottrell gate. J.S. (2). Have never found an elm seedling yet in Glamorgan, although ripe seeds are freely produced. $E d$.

1378. surculosa, Stokes. Common Elm. Llwyfanen gyffredin.

Common. Abundant. Native. Septal, sylvestral.

Both species of elm, including several varieties, are very frequently planted, and do better on the heavy clay soils of the Vale of Glamorgan than any other native species of tree.

\section{Humulus, Linn, 371.}

I 379. Lupulus, Linn. Common Hop. Llewig y blaidd, Pensoeg.

Local. Frequent. Native. Septal.

Llandaff; Penarth ! St. Fagans ! etc. J.S. Gower. E. F. Linton. J. of $B$. I892, p. 297. Merthyr Mawr; Pentyrch. Miss B. Mewslade; Horton and Port Eynon! Penrice. Miss S. Pendoylan. M.A.D. Ogmore. $V$. Lavernock. $H$. Loughor; Neath; Resolven; Port Talbot; Sutton; Bonvilstone ; Llantrisant; Aberdare; Llanishen; Rudry, etc. Ridd. Taffs Well ! where the rare male plant was noted. Ed.

\section{Urtica, Linn. 372.}

I380. dioica, Linn. Common Nettle. Dynhaden fwyaf, Dynhaden ysgar. Common. Abundant. Native. Viatical, septal, etc.

b. angustifolia, A. Blytt. Laleston. Ridd.

1382. urens, Linn. Small Nettle. Dynhaden leiaf.

Local. Abundant. Native. Viatical.

Although not exactly common, the localities are too numerous for quotation.

\section{Parietaria, Linn. 373.}

1383. officinalis, Linn. Pellitory of the Wall. Canhauawl, Cantafawd, Pelydr y gwelydd, Murlwyn, Barthlys.

Common. Abundant. Native. Rupestral.

b. fallax, Gren. \& Godr. Port Talbot; Merthyr Dyfan ; Cardiff, Ridd. 


\section{Myricaceæ.}

\section{Myrica, Linn. 374 .}

1384. Gale, Linn. Bog Myrtle. Madywydd, Gwyrddling, Mordywydd, Helygen Mair.

Rare. Abundant. Native. Ericetal, uliginal.

Crymlyn Bog, in 1773. Lightfoot. J. of B. 1905. p. 301. Llanishen; Bryn Garw; Llangynwyd. J.S. Twmpath, near Porthcawl; Fairwood Common. Miss B. Cefn Bryn! Miss S. Near Loughor and several places in Gower. T.H.T. Rhosili Down ; Pontardulais. Ridd.

\section{Cupuliferæ.}

\section{Betula, Linn. 375 .}

1385. verrucosa, Ehrh. White Birch. Bedwen gyffredin.

Common. Abundant. Native. Sylvestral.

Most of the records are for Betula alba in an aggregate sense.

The records for the segregates Nos. 1385 and I 386 are unsatisfactory. Three or more forms occur, and appear to me to be connected with each other by intermediate types. The nomenclature is likewise confusing. Further study is desirable.

I386. pubescens, Ehrh. Common Birch. Bedwen gyffredin.

This type certainly occurs frequently, and is probably abundant, and perhaps common.

Alnus, Linn. 376 .

1389. glutinosa, Medic. Common Alder. Gwernen.

Common. Abundant. Native. Sylvestral, paludal.

\section{Carpinus, Linn. 377 .}

I390. Betulus, Linn. Hornbeam. Oestrwydden gyffredin.

Local. Frequent. Alien? Sylvestral.

Llanishen; St. Fagans. J.S. Merthyr district. E. and F. Killay to Pennard; Neath; Wenvoe; Aberdare; Llaniltern. Ridd. Perhaps native in wood near Sychmant Ravine; often found in hedges. $E d$.

Corylus, Linn. 378.

139 I. Avellana, Linn. Hazel. Coll-lwyn. Collen.

Common. Abundant. Native. Sylvestral, septal.

This polymorphic species still awaits analysis. 


\section{Quercus, Linn. 379.}

1392. Robur, Linn. Common Oak. Dar, Derwen, Mesbren. Common. Abundant. Native. Sylvestral.

The three varieties-a. pendunculata (Ehrh.), b. intermedia (D. Don), and c. sessiliflora (Salisb.) occur; the first and third being about equally widely distributed, but the second relatively rare. Often planted, seldom producing fine specimens, $E d$. "A large hollow tree at Ty-draw, Treherbert, probably a portion of the ancient Rhondda valley woodlands." T.H.T. "A very perfect chain of varieties between pedunculata and sessiliflora about Pengam and Gelligaer." T.H.T.

\section{Fagus, Linn. 38r.}

1394. sylvatica, Linn. Common Beech. Ffawydden.

Common. Abundant. Native. Sylvestral.

This species, although often planted, is clearly native on the Old Red Sandstone and Mountain Limestone ridges between Tongwynlais and Draethen. The beech holds its own here, even in the absence of planting, seedlings being abundant.

\section{Salicineæ.}

Salix, Linn. 382 .

1 395. triandra, Linn. Almond-leaved Willow. Helygen deirgwrryw hirddail.

Local. Frequent? Native, Septal, etc.

Swansea. Gutch. Phyt. 1842. p. I45. Near Leckwith Bridge. J.S. Stream between Pyle and Port Talbot. Marshall and Shoolbred. J. of B. I902. p. 250. Cowbridge; Aberdare. Ridd.

$\times$ viminalis. Between Pyle and Port Talbot. Marshall and Shoolbred. Loc. cit.

$\times$ fragilis. Near Aberdare. Riddelsdell. J. of B. 1905. p. 217.

1396. pentandra, Linn. Bay-leaved Willow. Helygen beraroglaidd. Probably alien.

St. Fagans; St. Georges; Peterston, etc. J.S. Twmpath Valley. Miss B. Aberdare. Ridd.

1397. fragilis, Linn. Crack Willow. Helygen frau.

Local. Frequent. Native. Septal, etc.

Swansea. Gutch. Phyt. I842. p. I45. Cooper's Fields, etc. $J . S$. Ewenny and Cwm Alun. Miss $B$. Merthyr district. $E$. and $F$. Cadoxton and Dinas Powis, Ed. St. Fagans. I.

$\times$ alba. Swansea. Gutch. Phyt. 1842, p. 145. Pontcanna; Ely.

$V$. Aberdare, Ridd. 
I398. alba, Linn. White Willow. Helygen wen.

Local. Frequent. Native. Septal, etc.

Llanmorlais, introduced. E. F. Linton. J. of B. 1892. p. 297. Stream between Pyle and Port Talbot! looking truly wild. Marshall and Shoolbred. J. of B. 1902. p. 250. Frequent in district. J.S. Bodringallt Woods. $F l$. Rhondda. Ewenny! Miss $B$. Frequent in Gower ! Miss S. Merthyr district ! E. and F. Pontcanna. V. and $I$. Penarth ! H. Killay to Pennard! Loughor; Pantyffynon; Crumlin Bog; Margam Moors! Aberthin! Aberdare! Taffs Well! Peterston! Ridd.

b. vitellina, Linn. Swansea. Gutch. Phyt. 1842. p. 145. Aberdare. Ridd.

1399. cinerea, Linn. Common Sallow.

Common. Abundant. Native. Septal, etc.

$\times$ nigricans. Aberdare, Ridd.

$\times$ viminalis. Fairwater. Ridd.

I 400. aurita, Linn. Wrinkled-leaved Sallow. Helygen grynglustiawg, Helygen grych grynddail.

Common. Abundant, Native. Sylvestral.

× Capraa. Aberdare; Whitchurch. Ridd.

× cinerea. Aberdare; Whitchurch. Ridd.

1401. Caprea, Linn. Great Sallow. Helygen grynddail fwyaf.

Common. Abundant. Native. Sylvestral, septal.

$\times$ cinerea. Aberdare. Ridd.

1 402. repens, Linn. Dwarf Willow. Cor Helygen; Helygen y cwn.

Common. Abundant. Native. Glareal, ericetal, etc.

A very characteristic plant of the sand dunes. The habitats of the various forms of this species scarcely deserve enumeration.

$\times$ Capræa. Whitford Burrows, 1908 ; with the parents. Ed.

S. phylicifolia, Linn and S. nigricans, Sm. are excluded.

1405. viminalis, Linn. Common Osier. Helygen gyffredin afonawl. Common. Abundant. Native. Inundatal.

a. stipularis (Sm.). Three bushes, near the Canal, Crymlyn Burrows. Status doubtful. W. R. Linton. J. of B. I886. p. 376 . Margam Moors; Peterston; Aberdare. Ridd.

$\times$ Capraa $=($ Smithiana, Willd. $) . \quad$ Near Pennard Castle. Mr. D. Turner. Eng. Flora. Vol. IV. p. 229. Crumlin Bog; Port Talbot; Mawdlam; Cowbridge; Aberdare; Merthyr ; Peterston ; Taffs Well. Ridd. The Rev. E. F. Linton now regards this form as the hybrid of viminalis by cinerea. 
14II. purpurea, Linn. Purple Willow.

Aberdare, native. Ridd.

$\times$ cinerea. Taffs Well. Ridd.

viminalis. Aberdare; Leckwith Wood. Ridd.

\section{Populus, Linn. 383 .}

P. alba, Linn. White Poplar.

Frequently planted, and owing to its free propagation often counted as a native.

1414. tremula, Linn. Aspen. Aethnen, Crydaethnen. Tafod y gwragedd. Tafod y merched.

Local. Frequent? Native. Sylvestral.

Swansea. Gutch. Phyt. I842. p. I45. Penarth; Sully; Llandaff; etc. J.S. Here and there all through the Vale of Glamorgan. T.H.T. Merthyr district. E. and F. St.-y-Nil. M.A.D. and $V$. Michaelstone-le-pit. $H$. Glanrhyd; Craig-y-Llyn ; Neath; Perddyn Gorge; Wenvoe; Aberdare; Mountain Ash; Peterston. Ridd.

nigra, Linn. Black Poplar. This alien is very frequently planted.

\section{Empetraceæ.}

\section{Empetrum, Linn. 384.}

1416. nigrum, Linn. Crowberry. Creiglys.

Rare. Scarce? Native. Ericetal.

Mountains about Pont-nedd-Vechan. L.W.D. Mat. On Mynydd Merthyr; scarce, I89o. T.H.T. Hills between Aberdare and Merthyr. Ridd. The record for St. Lythans Down, quoted by Storrie and wrongly attributed to Dillwyn; quoted by Riddelsdell, but rightly attributed to Nicholson, rests on the following note :"Crossing it [St. Lythans Down] to the S., a delightful valley occurs, called Dyffryn; where grow Sison verticillatum and Empetrum nigrum, in abundance." Nicholson's Travellers' Cam. Guide. I 840. p. 128 .

\section{Coniferæ.}

\section{Juniperus, Linn. 386 .}

1419. communis, Linn. Common Juniper. Merywen cyffredin.

Local. Frequent. Native. Rupestral.

Gower. Gutch. Phyt. 1842. p. I45. Hirwaun Common? J.S. The Barry Island locality recorded in Flora of Cardiff by Storrie acknowledged to be founded on mistake ? of Iolo Morganwg. J.S. (2). Nicholaston Woods, etc. Ridd. Pwlldu; Horton; and westwards to Paviland, Ed. 
Taxus, Linn. 387 .

1421. baccata, Linn. Common Yew. Ywen. Pren-yw.

Local. Frequent. Native. Sylvestral.

The habitats are too numerous for quotation. Frequently planted, but clearly a native, or at least indistinguishable from such, near St. Andrews, Wenvoe, and Cwrt-yr-Ala. The seeds are eaten by thrushes and blackbirds for the sake of the sweet arils. Seedlings are often abundant. $E d$. Fine examples of large old trees in the Churchyards at Glyncorwg, Llanishen, and Ilston. T.H.T.

\section{Pinus, Linn. 388.}

1 422. sylvestris, Linn. Scotch Fir. Pinwydden wyllt, Ffynidwydd.

Status doubtful, but according to Mr. Riddelsdell, native on the hills above Aberdare. "A $\log$ of $P$. sylvestris lay in bog of Llyn Vach at W. end in 1885 ; it may have been brought there, as no stump could be found." T.H.T. Ripe seeds are rather difficult to secure in quantity, especially from isolated plants. A large cone may not yield one. Have never seen a wild seedling. Ed. 


\section{Hydrocharideæ.}

Elodea, Michx. 380 .

1424. canadensis, Michx. Water-Thyme.

Local. Scarce. Denizen. Lacustral.

Leckwith Common! Grangetown, Merthyr Canal, \&c. J.S. Ewenny River. M.A.D. and $V$. Glyn Neath. Ridd. Apparently becoming scarcer every year.

\section{Hydrocharis, Linn. $3 y 0$.}

1425. Morsus-ranæ, Linn. Frog's-Bit. Alaw lleiaf,

Local. Scarce. Native. Lacustral.

E. Moors, Grangetown ! Leckwith Common ! \&c. Plentiful. J.S. Crymlyn Bog. Lightfoot. J. of B. 1905. p. 299. Port Talbot. Ridd. The plant has quite disappeared from the reens around Cardiff, in which it was very abundant in I891. Ed.

\section{Orchideæ.}

Liparis, Rich. 393.

1428. Loeselii, Rich., var. ovata, Ridd. Fen Orchis.

Rare. Frequent. Native. Uliginal, paludal.

One locality only. H. J. Ridd. J. of B. I905. p. 274.

\section{Neottia, Linn. 395 .}

1430. Nidus-avis, Rich. Bird's-nest Orchis.

Local. Frequent. Native. Sylvestral.

Margam Woods; Penrice. Dr. Turton. Pont Nedd Vachn. Mr. J. Woods, junior. B.G. Pontardawe. Dillwyn. Gutch. Phyt. 1842. p. I80. St. Fagans, Wenvoe, near Castell Coch ! Coytrahen. J.S. Between Lisvane and Ruperra. J.S. (2). Bridgend, Coedriglan. G.T. Barry! Dinas Powys! D. Leckwith, I841. J.E. Pendoylan. I. Rhiwbina. $V$. Garth wood. Ridd. 


\section{Listera, R.Br. 396.}

1432. ovata, R.Br. Common Tway Blade. Caineirian, Gefell-lys Dwyddalen.

Local. Frequent. Native. Sylvestral, etc.

Too common in the lowlands for the localities to be citerl. Much rarer in the uplands. Merthyr District. E. and $F$.

\section{Spiranthes, Rich. 397.}

1433. autumnalis, Rich. Autumnal Ladies' Tresses. Teircaill, Caineirian nydd-dröedig.

Local. Frequent. Native. Pascual.

Town Hill, Swansea, and Mumbles. Gutch. Phyt. 1842. $p$. I80. Porthcawl, plentiful. R. E. and F. Cundall. J. of B. I902. p. 317. North Road; Llanishen; Sully! Barry! Pencoed; etc. Frequent. J.S. Penllergare : Coedriglan. G.T. Lower Penarth ! $H$. Llantrisant. W.C. Southerndown! Miss B. Llandough to Michaelstone-le-Pit. Mrs. Russell. Frequent in Gower ! Miss S. Lavernock ! M.A.D. and V. Llandough, I847. J.E. Langland Bay. I. St. Brides Major; Llandough. $V$. Horton ! Oxwich ! Pop Hill, Dinas Powys! Ed.

\section{Epipactis, Adans. 401.}

1441. Iatifolia, All. Broad-leaved Helleborine. Caldrist llydanddail. Local. Frequent. Native. Sylvestral.

Cogan; Swanbridge; Llanishen! Cowbridge; Pencoed; etc. Frequent. J.S. Dinas Powys! J.S. (2). Penllergare. G.T. Cwrtyr-Ala ! Castell Coch ! $H$. Llandough, Cowbridge. Miss $B$. Moulton; Sully. D. Merthyr District. E. and F. Hensol, I 833. J.E. Fairwater. $I$. Rhiwbina. $V$. Llandough Reservoir. $T$. $W$. Proger. Wenvoe ! Llanishen to Caerphilly ! Ed. Nicholaston Woods; Glyn Neath; Resolven; Perddyn and Neddfechan gorges ; Aberafan and Kenfig Pool; Aberdare; Hirwaun; Pontyclun ; Rudry. Ridd.

1445. palustris, Crantz. Marsh Helleborine. Caldrist y gors.

Local. Abundant. Native. Uliginal, paludal.

This plant is almost characteristic of the wet bottoms amongst the sand dunes, and is often very abundant, from the Ogmore to Whitford. Separate records for the various burrows are therefore unnecessary. Culver House ; Llanishen; Bridgend. J.S. Ystradowen! M.A.D. and V. Llanishen. Mrs. Traherne and D. Bryngarw, rare. Miss $B$.

\section{Orchis, Linn. 402.}

1 447. pyramidalis, Linn. Pyramidal Orchis. Tegeirian bera, Tegeirian côch yr hâf.

Local. Scarce. Native. Pascual, etc.

Port Eynon and Horton. Miss S. Barry Island! M.A.D. and $V$. Spec. in U.C.Hb. I892, Ed. Radyr, I840; white-flowered. J.E. Llanilid; Porthkerry; near Rhiwbina. J.S. (2). Kymin Cliff, on red marl, Penarth! Ed. Sully; Monknash; Dunraven. Ridd. 
1452. Morio, Linn. Green-winged Meadow Orchis. Tegeirian y waun, Tegeirian ynfydyn.

Local. Abundant. Native. Pascual.

This orchid is very abundant and widespread on the Lias. It is very commonly associated with the cowslip and the adder's-tongue. As it flowers early-with the cowslip-it has probably been overlooked. rhildren in S.E. Glamorgan gather it in great quantities. There are several distinct colour varieties. The only records outside S.E. Glamorgan are:-Swansea; Aberafan; Aberdare. Ridd. Pwllypant. $V$.

1453. mascula, Linn. Early Purple Orchis. Hosanau ' $r$ gôg, Tegeirian côch y gwanwyn, Caill y ci.

Local. Frequent. Native. Sylvestral, pratal.

Too common for citation of the records. Probably occurs in every district, but is not yet recorded from the western half of the county, with the exception of the peninsula of Gower.

1455. incarnata, Linn. Common Marsh Orchis.

Rare. Frequent. Native. Uliginal, paludal.

Kenfig Burrows! Marshall and Shoolbred. J. of B. 1902. pp. 248, 250. Talygarn Bog. $V$. Cog Rises! and near Llanmadoc! Ed.

1456. latifolia, Linn. Broad-leaved Marsh Orchis. Tegeirian y gors. Common. Abundant. Native. Uliginal, paludal.

$\times$ maculata. Aberdare. Ridd. Kenfig Burrows! 1908 and 1909. Ed.

1457. maculata, Linn. Spotted Palmate Orchis. Tegeirian manog byseddog.

Common. Abundant: Native. Paludal, etc.

\section{Ophrys, Linn. 404 .}

1459. apifera, Huds. Bee Orchis.

Local. Frequent. Native. Pascual.

Porthkerry ! and Flat Holme ! Lightfoot. J. of B. 1905. p. 299. Penrice and Margam. Dr. Turton. B.G. Ball Cottage! Sully; Barry ! etc. J.S. Ely Valley. G.T. Ewenny. W.C. Penarth! Lavernock! Cogan ! H. Llantwit Fardre; Monknash. Miss B. About Penarth! Mrs. Russell. Barry Island! V. and M.A.D. Llandough! i 849. J.E. On Oxwich Burrows, becoming extinct. Miss S. Aubrey Arms and Cowbridge. W. F. Evans, Ridd.

1462. muscifera, Huds. Fly Orchis. Caineirian yr ednogyn.

Said to have been found near St. Nicholas, by Archdeacon Bruce, in I883. Probably a genuine record. 


\section{Herminium, Linn. 405.}

I 463. Monorchis, R.Br. Musk Orchis.

Recorded from Beaupré by Mrs. Traherne. Trans, Cardiff Nat. Soc. I882. p. 21. As this rare orchid is found in Somerset and Gloucester, the record, although a doubtful one, is included. The plant should be carefully searched for.

\section{Habenaria, Willd. 406.}

I 464. conopsea, Benth. Fragrant Orchis. Tegeirian peraroglaidd.

Local. Frequent. Native. Pratal, etc.

St. Fagans; Llanishen; Pencoed; Bridgend; etc., rather frequent. J.S. Barry. $H$. Southerndown. Miss $B$. Merthyr District. $E$. and $F$. Ystradowen. M.A.D. Near Radyr, 1830; white variety near Llandough Rectory. J.E. Pencoed; Talygarn Bog. V. Margam Marshes. Ridd. Barry Island! I891. Ed.

I 466. albida, R.Br. Small White Orchis.

Rare. Scarce. Native, Pascual, ericetal.

Very rare. Near Cwm Ffrwd. J.S. and T.H.T. Merthyr district. E. and F. Near Coity. J.S. (2). Storrie knew the species, as there is a specimen of his from Gourock in the Welsh Herbarium.

1467. viridis, R.Br. Frog Orchis. Llys ysgyfarnog, Baldar blodeuwyrdd.

Rare. Scarce. Native. Pascual, ericetal.

Near Llantrithyd; Hirwaun. J.S. Rhossili ; Bridgend. Ridd. Port Eynon; Middleton, Rhossili. Miss $S$. Llandough, I84I, abundant. J.E. St. Bride's Major. $V$. Marcross. Miss $K$. Richards, sp. ! Dunraven, two specimens only! Ed.

1468. bifolia, R.Br. Lesser Butterfly Orchis. Tegeirian dwyddalenawg.

Local. Frequent. Native. Pascual, pratal, sylvestral.

St. Fagans; St. George's; Boverton; etc., not common. J.S. Leckwith Woods. Miss Ollivant. Neath Valley. G.T. and $H$. Cwrt-yr-Ala. $H$. Near Cwm Mawr Wood, Dunraven. Miss $B$. Barry. D. Merthyr district. E. and F. Porthkerry. M.A.D., $I$., and $V$. Michaelstone-le-Pit. Mrs. Russell. Mead Moor; Rhossili ; Penrice. Miss S. Llandough, I831. J.E. Rhiwbina; Castell Coch. V. Llandough ! I891, segregate. U.C.Hb., Ed. Some of these records are for the old aggregate-bifolia, and therefore probably include the following species.

I 469. chloroleuca, Ridley. Greater Butterfly Orchis.

Rare. Scarce. Native. Pascual, pratal, sylvestral.

Sully Wood; St.-y-Nyll. J.S. Llandough and Penarth. J.S. (2). Barry; 2-6-04. D. Vale of Neath, where both segregates are very abundant and seem to merge into each other. $H$. Flemingstone, I905 ! Penmark ! Llandough ! near Penarth! One or two isolated specimens only in each locality, but large, fine, and, I think, quite typical. Ed. 


\section{Iris, Linn. 408.}

\section{8o. Irideæ.}

I 47 I. fœetidissima, Linn. Fœtid Iris. Hyllgryg, Llys'r Hychgryg, y Gloria.

Local. Abundant. Native. Sylvestral, etc.

Too common near the coast from Cardiff to Neath for citation of the records. Rarer in Gower, for which the records are given, and with only one inland record:-Penllergare, Dillwyn. Gutch. Phyt. 1842. p. 180. Horton; Penrice. Miss S. Penclawdd. T.H.T. Nicholaston Woods. Ridd. The species is not a calcicole one in Glamorgan. It is very abundant on and near the burrows, and still more so in the little wooded cwms near the coast. In the latter, as at Marcross, it is often the dominant species of the undergrowth.

1472. Pseudacorus, Linn. Yellow Flag. Cammined y dwr, Gellhesgen. Common. Abundant. Native. Paludal.

The variety acoriformis, (Bor.) is well distributed throughout the county.

\section{Narcissus, Linn. 413.}

\section{I. Amaryllideæ.}

1481. Pseudo-narcissus, Linn. Common Daffodil. Gylfinog cyffredin, Croeso gwanwyn, Cenhinen Pedr.

Local. Abundant. Native. Sylvestral, etc.

Coedriglan. Miss Ollivant. Llanishen, etc. J.S. Cefn On ; with a marked tendency to double by malformation of the stamens. J.S. (2). Meadow at Nottage, abundant. R.E. and F. Cundall. $J$. of B. 1902. p. 3I7. Wrinstone. H. Ewenny and Coed-yQuintin, near Candlestone. W.C. Cwm Alun, near Southerndown Road! D., Miss B., and $V$. Llanbradach! M.A.D. and $V$. Oxwich! Miss S. Pencoed! $V$. Pendoylan and Bonvilstone. $I$. Draethan. Ed. Penllergare; Gower, rather common; Caerau. Ridd.

Several species of Narcissus have established themselves in various parts of the county. The most interesting of these, including all those which form a permanent part of the vegetation, are recorded below.

a. $N$. telemonius plenus $=(N$. major, Linn. $)$ An almost pure green form of this is very abundant near Coed-y-gores! on the Old Red Sandstone; and occurs also at Penylan, Candlestone, and Ewenny. $V$. Mr. T. H. Thomas, who first called attention to it, sent specimens to Mr. Burbidge, of Dublin, who reported that he had not noticed it before. Barr also had not seen it, so that it is probable that it originated from the ordinary form, as a bud-variation, in the district where it now occurs. It was named by Burbidge "Thomas" Virescent." The normal yellow form of this daffodil occurs occasionally, but only, I believe, as an outcast. Even in gardens, it frequently fails to multiply and flower regularly in Glamorgan. 
b. N. incomparabilis, Mill. "Grows in the little Park at Margam, and Mrs. D. Llewelyn has shown me good ground to believe that it has continued to do so for at least two centuries." L.W.D. Mat. Near Pencoed and Coed Mwstwr. J.S.

c. N. biflorus, Curtis. In abundance in Kenfig village, not far from the Church. Mr. Bicheno. L.W.D. Mat. Kenfig, a meadow full of it. R.E. and F. Cundall. J. of B. 1902. p. 317. Bank of Ely River. J.S. Neath Valley. G.T. Candlestone sandhills ! perhaps planted. Miss $B$. Barry. D. Meadow opposite Cwrt-y-fil, 1848. J.E. Porthkerry cliffs, June, 1904. I. Penrice. Ridd.

d. N. poeticus, Linn. Very rare, Llanishen Reservoir. J.S. Ladies' Field, St. Hilary; and near How Mill. J.S. (2). Near Southerndown. Miss $B$. Once very abundant in Cathays Parknever seeding. W. W. Pettigrew. Capel Celyn-abundant. W.W.P. Pwllypant, growing with $N$. Pseudo-narcissus. $V$. The record in L.W.D. Mat. under N.-minor "Rocks below old Castle at Penrice" may be provisionally placed here.

\section{Galanthus, Linn. 414.}

1486. nivalis, Linn. Common Snowdrop. Eiriawl, Cloch baban. Local. Frequent. Native, but often planted. Sylvestral, etc.

Llanmadoc Hill, near Cheriton; Penllergare. L.W.D. Mat. Rare. Near Coed-y-gores; Nant Dulas; and Bridgend. J.S. Cefn Mably; Lisvane ! Castell Coch. J.S. (2). Court Colman, near Bridgend. Mrs. Traherne, G.T., and W.C. Merthyr Mawr and Dunraven. Miss B. Oxwich; Penrice. Miss S. Ruperra. $V$. Tondu ; Radyr. Ridd. Llanmaes ! Hamston-fawr, near Dyffryn ! Draethen! $E d$.

Tamus, Linn. 416 .

\section{Dioscoreæ.}

1489. communis, Linn. Black Bryony. Gwinwydden dd Rhwymyn y coed, Paderau'r gath.

Common. Abundant. Native. Septal, sylvestral.

\section{Ruscus, Linn. 417.}

\section{Liliaceæ.}

1490. aculeatus, Linn. Common Butcher's Broom. Celynen Mair.

Local. Abundant. Native, often planted. Ericetal, sylvestral,etc. Shore of Oxwich Bay, near Pennard Castle. Westcombe. Phyt. I 844. p. 780. Sully ! Leys; Coytrahen, apparently wild ; rare. J.S. Lavernock! J.S. (2), H., M.A.D., and I., where it was almost certainly planted. Ed. Near Blaenrhondda. Fl. Rhondda. Park Mill ; Penrice ; general on Gower cliffs. Miss S. Pwlldu ; Oxwich Point; Nicholaston Woods; Cowbridge; Peterston. Ridd. Penarth! Dinas Powys ! Ed. Horton ! very abundant and clearly 
wild, where it forms with dwarf hazel, blackthorn, privet, furze, and juniper a scrub formation on the ledges of the limestone cliffs. I have only succeeded in finding one ripe berry in twenty years. Fine imported specimens, with abundant fruit, were sold in Cardiff last Christmas (1910) as French holly. Ed.

\section{Asparagus, Linn. 418.}

1491. officinalis, Linn. Asparagus. Gwillon, Merllys cyffredin, Llys y dyfrglwyf.

Rare. Scarce. Native. Littoral.

Meadows between Cowbridge and the sea; about Cardiff. Dr. Turton. B.G. Near Loughor; Worms Head and neighbouring coast; Singleton. Gutch. Phyt. I842. p. 180. Near Grangetown; Aberthaw; very rare. J.S. Sker sands. Marshall and Shoolbred. $J$. of $B$. 1902. p. 248. Cliffs, Oxwich Bay. Ridd. $J$. of B. 1905. p. 9I. Fontigary. G.T. Port Eynon! Miss S. Sands at Oxwich Bay; Port Talbot ; Broughton Bay. Ridd. Horton! Sully Beach! Ed.

The above records are for the aggregate species. The variety altilis occurs at Oxwich, Port Talbot, and Sully; the variety maritimus at Oxwich, Broughton, Horton, etc., on the limestone cliffs and at Sker on the sands.

\section{Polygonatum, Adans. 4I9.}

1 493. multiflorum, All. Common Solomon's Seal. Sel Selyf.

Rare. Frequent. Native. Sylvestral.

Near Llwyn y grant; Coedriglan; Llanedarn. J.S. Castell Coch, fairly plentiful. H., M.A.D., and V. Capel Celyn. T.H.T. Creigiau. M.A.D., V., and $I$. Pendoylan. $I$. Near Vaynor. $E$. and $F$. Wenvoe. Ridd. Draethan! Ed.

\section{Convallaria, Linn. 421 .}

I 496. majalis, Linn. Lily of the Valley. Clych Enid, Alaw crewyll.

Rare. Frequent. Native. Sylvestral.

Coedriglan. J.S. Wood, near Castell Coch. J.S. (2). Penllergare. Ridd. Near Vaynor. E. and F. Little Garth Wood ! very abundant and unmolested in I89I ; nearly exterminated, I9I0. Ed.

\section{Allium, Linn. 423.}

Ampeloprasum, Linn. Wild Leek.

This plant was first observed by D. Newton on one of the two islands known as the Holmes. Ray. Syn. I689. Ed. I. p. I65. It still occurs on the Flat Holme (v. c. 4I) and Steep Holme (v.c. 6). As it has succeeded in the struggle for existence for two centuries and a half, it may be deemed worthy of a permanent place in the British Flora, even if its status be no more than that of a denizen. Storrie's experiments prove that the wild plant differs much in flavour from the types cultivated in gardens. 
I 50 I. vineale, Linn. Crow Garlic. Craf gwyllt, Garlleg gwyllt.

Local. Frequent. Native. Pratal, pascual, rupestral.

Port Tennant. Gutch. Phyt. I842, p. i 80. Newton. R. E. and F. Cundall. J. of B. 1902. p. 317. St. Hilary. J.S. Once abundant near Cathays; Llanishen! J.S. (2). Porthkerry ! D. Barry. $V$. and $I$. Horton ! Miss S. Quoity Green; Penarth; S. Cornelau; Pengam Marshes. Ridd. Cheriton! Llantwit Major ! Cliffs from Nash Point to Breaksea Point, often abundant! Aberthaw ! Peterston Moors, on banks of Ely ! Ewenny River, near Ogmore Castle ! Ham ! Dinas Powys ! and other places left unrecorded.

I do not think the varieties of this species deserve higher rank than states. Transitional forms are frequent, and two forms often grow together. $E d$.

I 502. oleraceum, Linn. Field Garlic.

Rare. Scarce. Native? Pratal?

Penylan. Ridd. Llanishen. V. Spec. Vach Herb. I

1508. ursinum, Linn. Ramsons. Craf y geifr.

Local. Abundant. Native. Sylvestral.

Too common in the lowlands, from Gower to Cardiff, for the detailed citation of the records. Apparently scarce in the uplands and on the coal-measures. Glyn Neath; Nedd-fechan Glen; Penllergare. Ridd. Merthyr district. E. and F.

\section{Scilla, Linn. 425 .}

I510. autumnalis, Linn. Autumnal Squill.

Rare. Scarce. Native. Glareal.

Near Marcross. Nat. Hb. Specimen collected by Storrie. This record was apparently accidentally left out of his Flora of Cardiff. He may at first have doubted his own diagnosis, for in his interleaved copy, opposite $S$. verna, are the following entries, made at different times:- "See if this is not autumnalis"; "autumnalis is the one on the cliffs." The record is a good one-the specimen is certainly one of autumnalis, and Storrie could scarcely have made a mistake as to the locality.

I 5 I I. verna, Huds. Vernal Squill. Serenyn y gwanwyn.

Local. Frequent. Native. Glareal, sublittoral.

Worms Head ! J. Woods, junior. B.G. Mumbles! and other places in Gower! Gutch. Phyt. I 842. p. 180. Many other more recent records for Gower, extending from Swansea ! to Burry Holm ! Rare elsewhere. Near Llancarfan. J.S. Near Candlestone. J.S. (2). Porthcawl! M.A.D. and $V$. The records for the Lias rocks east of Dunraven are doubtful. Storrie's plant was, as already stated above, a specimen of autumnalis.

I512. festalis. Salisb. Wood Hyacinth. Bwtias y gôg, Cenhinen y brain, Croeso hâf, Glas y llwyn, Cloch yr eos.

Common. Abundant. Native. Sylvestral. 


\section{Ornithogalum, Linn. 426.}

O. umbellatum occurs here and there fully established, but can scarcely be said to have attained the status of a denizen. There are records for Cooper's Fields, St. Fagans, near Pontypridd, Llynfi Valley, Merthyr Mawr, Dunraven, Southerndown Road, Southerndown, and Horton.

O. pyrenaicum was recorded by Storrie as very rare in Porthkerry Woods. As it has been searched for there by several botanists without success, the record must remain a doubtful one.

\section{Gagea, Salisb. 430 .}

1520. fascicularis, Salisb. Yellow Star of Bethlehem.

One doubtful record. "Specimen in Cardiff Museum, labelled, Castell Coch Woods, 3.5.43." Collector's name unknown. J.S. No plants have been found since that date, and the specimen has disappeared.

\section{Colchicum, Linn. 432.}

1522. autumnale, Linn. Meadow Saffron.

Local. Scarce. Native. Pratal.

Near the Lime Works, Llandough. R. Drane. Now extinct. Boverton-an escape. J.S. Near Cogan Pill and Llandough. J.S. (2). Wenvoe. Mrs. Traherne, Laleston. Ridd.

\section{Narthecium, Moehr. 433.}

1523. Ossifragum, Huds. Bog Asphodel. Llafn y bladur, Gwaew y brenin. Local. Frequent. Native. Uliginal.

Too common for detailed record, excepting in the Vale of Glamorgan, where it is rare. St. Fagans, Peterston! J.S. Ystradowen. M.A.D. and V. Pendoylan! I.

\section{Paris, Linn. 435.}

1525. quadrifolia, Linn. Herb Paris. Cwlwm cariad.

Local. Frequent. Native. Sylvestral.

Briton Ferry; Kilvey; Nicholaston Wood and other woods in Gower. Gutch. Phyt. I842. p. 180. Woods at Park. L.W.D. Mat. Coedriglan, Cwm George! Llanishen! Lisvane! St. Fagans, etc. J.S. Wrinstone! H. Castell Cocb. H., M.A.D., I., and V. Bridgend and Ewenny. W.C. Creigiau. D. Morlais Castle. E. and F. Park Mill. Miss S. Leckwith ! I83I. J.E. Llanmadoc; Wenvoe; Ystradowen. Ridd.

\section{Juncaceæ.}

\section{Juncus, Linn. 436.}

1526. bufonius, Linn. Toad Rush. Brwynen y llyffant. Common. Abundant. Native. Inundatal, viatical, etc. 
1528. squarrosus, Linn. Heath Rush. Brwynen troellgoryn.

Common. Abundant. Native. Ericetal.

Rather scarce in the lowlands, but there are several records from Gower and the valley of the Ddaw:-Mead Moor; Rhossili; Oxwich. Miss S. Cefn Bryn ! Ed. Sully Moors. $H$.

1530. Gerardi, Loisel. Mud Rush.

Local. Abundant. Native. Paludal, littoral.

This rush is often a dominant, sometimes almost the only, constituent of the vegetation in shallow depressions near high-water mark. It is found in suitable localities all along the coast, and is quite abundant in the Ely Estuary.

1534. glaucus, Leers. Hard Rush. Brwynen galed.

Common. Abundant. Native. Paludal, inundatal, \&c.

Storrie's note " Not common near Cardiff" is erroneous.

1535. effusus, Linn. Soft Rush. Pabwyren, Canwyll-frwynen.

Common. Abundant. Native. Paludal, inundatal, etc.

This rush often occurs with a compact inflorescence resembling that of the following species-number 1536 .

$\times$ glaucus (diffusus, Hoppe). Crymlyn Bog. E. F. Linton. J. of B. I892. p. 297. Peterston Moors. Ridd.

I536. conglomeratus, Linn. Common Rush. Brwynen bellenaidd.

Common. Abundant. Native. Paludal, inundatal, etc.

This rush also occurs with an open inflorescence like that of effusus. Collected at Kenfig in this state; 4-7-I908. Ed.

1537. maritimus, Lam. Lesser Sea Rush. Morfrwynen.

Local. Abundant. Native. Paludal, littoral.

This rush affects stations near and above high water mark, and is very abundant on the coasts of the western half of the county. It forms a distinct and striking feature of the landscape on the landward side of the salt meadows of the Loughor estuary. It is comparatively rare to the east of Swansea, and the ascertained localities therefore deserve record. Lower Grangetown. Rare. J.S. Sully Island ! $V$. Barry Salt Marsh ! Kenfig River banks ! Ed. Port Talbot; Jersey Marine. Ridd.

I 538. acutus, Linn, Greater Sea Rush. Barfrwynen.

Local. Scarce. Native. Littoral.

Common on sandhills about Swansea. L.W.D., B.G. Cromlyn Burrows. Winch. add., N.B.G. Near Neath Canal and Newton Nottage sandhills. Gutch. Phyt. 1842. p. I80. Near Ogmore Castle. J.S. Oxwich! Miss S. Llanmadoc! V. Tennant's Canal side, Swansea, 1834. Nat.Hb. Jersey Marine; Port Talbot. Ridd. Whitford! Llangenydd! Kenfig ! also a type intermediate between maritimus and acutus at Whitford Burrows. Ed. 
I539. supinus, Moench. Lesser-jointed Rush. Brwynen algron.

Common. Abundant. Native. Uliginal, paludal, \&c.

b. Kochii, Bab. Fairwood Common. IV. R. Linton. J. of B. I 886 . p. 376 .

1540. obtusiflorus, Ehrh. Blunt-flowered Rush. Brwynen glymmog a blodau blaendwn.

Local. Abundant. Native. Paludal, etc.

Oxwich! Miss S. and D. Fry. J. of B. 1888, p. 57. Whitford Burrows ! Mouth of Kenfig River ! Ed. Rhossili; Crumlin Burrows ; Port Talbot ; Peterston ; Welsh St. Donats ; Ystradowen Moor. Ridd.

I 542. lamprocarpus, Ehrh. Shiny-fruited Rush. Brwynen glymmog glaer-gib.

Common. Abundant. Native. Paludal.

\section{3. alpinus, Vill.}

Rare. Scarce. Native. Paludal ?

One record only, for which we are indebted to Mr. A. Bennett, who sends the following interesting notes. "Near Cardiff. Sept,, I902. Vachell spec." "The occurrence of this species may seem odd, yet it is not so, for it occurs in 15 of the Dutch Friesian islands, in three of the German Friesian Islands, in several of the Danish islands, in France also (as $J$. anceps), Belgium, N. Germany, etc. It probably occurs in the Lake Counties of N. England; (spec. in Norwich Mus: ?)-often very difficult to separate from J. lamprocarpus." "I include under J. alpinus, J. fusco-ater, Schreber, which the Cardiff plant really more nearly resembles." "The other recorded British localities for this plant all lie N. of the Clyde."

subp. atricapillus, Day. Porthcawl sands. Ridd.

1544. acutiflorus, Ehrh. Sharp-flowered Rush. Brwynen glymmog a blodau blaenfain.

Common. Abundant. Native. Paludal.

b. multiflorus, Weihe. Craig-y-llyn. Ridd.

\section{Luzula, DC. 437.}

1549. Forsteri, DC. Narrow-leaved Hairy Woodrush.

The records for this species are all doubtful, and therefore that for the hybrid between this and the next. The species is recorded as not uncommon by J.S. and in L.W.D.Mat. No recent records exist, although many localities have been searched by several observers. Narrow-leaved individuals of vernalis have probably been mistaken for the real plant. The record in T.B. is not attested by a specimen, and is probably based on the doubtful record in L.W.D. Mat. 
1550. vernalis, DC. Broad-leaved Hairy Woodrush. Brwynen flewog. Local. Frequent. Native. Sylvestral.

Coed Mawr; St. Fagans; Coedriglan; Coed Mwstwr. J.S. Frequent in Gower. Miss S. Penllergare. G.T. Merthyr district. $E$. and $F$. Pendoylan ! $I$. and $V$. Rhubina. $V$. Graigafan; Aberdare ; Caerphilly. Ridd. Little Garth ! Hensol ! Llanishen ! Lisvane! and many other localities in the Vale of Glamorgan. Ed.

1551. maxima, DC. Great Woodrush. Brwynen y goedwig.

Local. Frequent. Native. Sylvestral, rupestral, etc.

Storrie's records are somewhat doubtful. The species is never dominant in Glamorgan, I believe, as it so frequently is elsewhere, and is most abundant on the escarpments of the coal measures.

St. Fagans; Wenvoe. J.S. Coedriglan. G.T. Vale of Neath ! $H$. Gower. Miss S. Castle-upon-Alun. Miss B. Craig-y-llyn ! Cwmparc! and other similar localities. Ed. Ystalyfera; Glanrhyd; Swansea; Melincourt Glen; Aberdare; Ystradowen. Ridd.

I554. campestris, DC. Field Woodrush. Brwynen flewog y maes.

Common. Abundant. Native. Pascual.

1555. erecta, Desv. Many-headed Woodrush.

Local. Frequent. Native. Ericetal.

Rhondda, Cynon, and Dare Valleys ; Caerphilly ! Glyncorwg. Frequent. J.S. Pendoylan ! V. Dumbath Valley. Miss. B. Lisvane ! Peterston! Hensol ! and other places. The varieties $a$. and $b$. of the London Catalogue are connected by intermediate types, growing close together, sometimes perhaps on the same stock.

\section{Typha, Linn. 438.}

\section{Typhaceæ.}

1556. Iatifolia, Linn. Great Reedmace. Cynffon y gath, Hesgen felfeclog fwyaf.

Local. Frequent. Native. Paludal.

The localities in the lowlands are widespread and too numerous for citation. Rare in the uplands and on the coal measures. Merthyr district. $E$. and $F$. Aberdare. Ridd.

1557. angustifolia, Linn. Narrow-leaved Reedmace. Hesgen felfedog, Cynffon y gath leiaf.

Rare. Abundant. Native. Paludal.

Crymlyn Bog. Lightfoot. J. of B. 1905. p. 299. Oxwich ! Miss S. Penllergare. Trans. Swansea Sci. Soc. I895-6. p. 76. Port Talbot. Ridd.

\section{Sparganium, Linn. 439.}

I 558. ramosum, Huds. Branched Bur-reed. Cleddyflys cangenawg. Local. Abundant. Native: Paludal.

Quite common in the lowlands, and equally so in W. and E. Glam. Rare elsewhere. Pontardawe. Trans. Swansea Sci. Soc. I893-4. p. 26. Merthyr district. E. and F. Llwydcoed; Caerphilly. Ridd.

b. microcarpum, Neuman. Flemingstone Moor. Ridd. 
1559. neglectum, Beeby.

Oxwich; Burry Green; Crumlin Bog; Llantwit Major; Cwrtyrala; Cowbridge; St.-y-Nyll ; Fairwater ; Llandaff to Radyr. Ridd.

I 560. simplex, Huds. Unbranched Bur-reed. Cleddyflys undwf syth. Local. Frequent. Native. Paludal.

Singleton and Neath. Gutch. Phyt. 1842. p. I80. Leckwith! Llandaff; Cadoxton, etc. J.S. Ewenny. Miss B. Ystradowen. M.A.D. Penllergare. Trans. Swansea. Sci. Soc. 1895-6. p. 76. Crumlin Bog; Porthcawl; Fairwater; Aberdare Valley. Ridd. Fairwood Common! Overton, Port Eynon! Hensol ! Flemingstone Moor! Ed.

b. Iongissimum, Fr. Crumlin Bog. Ridd.

1561. affine, Schnizl. Floating Bur-reed.

Rare. Scarce. Native. Lacustral.

Llyn Fach !! 1892 to 1905. Ed. Llyn Fawr. Ridd.

1562. minimum, Fr. Small Bur-reed. Cleddyflys undwf nofiadwy.

Rare. Scarce. Native. Lacustral.

Cromlyn Bog. E. Forster, junior. B.G. Singleton Marsh ; Old Red-Jacket canal. Gutch. Phyt. I842. p. I80. Merthyr Canal; Hensol Lakes. J.S. Pitton Common; Welsh St. Donat's. Ridd.

\section{Aroideæ.}

Arum, Linn. 440.

1563. maculatum, Linn. Common Cuckoo-pint. Pidyn y gog, Cala'r gethlydd.

Common. Abundant. Native. Sylvestral, septal.

Pure green and spotted-leaved types occur about equally abundant and evenly distributed all over the county. The dark spots vary much in size and number. It is probable that we have under this name two distinct segregates and their hybrid offspring.

\section{Acorus, Linn. 441 .}

1565. Calamus, Linn. Sweet Flag. Gellhesgen perarogl.

Rare. Scarce. Alien. Paludal.

Briton Ferry. Mr. Player. Gutch. Phyt. I842. p. 180. Penllergare ! G.T. and Ridd. Almost certainly introduced. The species flowers, but does not fruit, at the Roath Park Bot. Garden. $E d$. 


\section{Lemnaceæ.}

Lemna, Linn. $\mathbf{4 2}$.

1566. trisulca, Linn. Ivy-leaved Duckweed.

Local. Abundant. Native. Lacustral.

Swansea. E. F. Linton. J. of B. 1890. p. 157. Very common about Cardiff ! J.S. Glyncornel, etc. Fl. Rhondda. Penarth; Wrinstone; etc. $H$. Colwinstone; Efail Isaf. Miss $B$. Fairwater. $V$. Margam to Aberafan Moors; Flemingstone Moors. Ridd. Grangetown! Leckwith Common! E. Moors! St.-y-Nyll! Ed.

1567. minor, Linn. Lesser Duckweed. Bwyd hwyaicl, neu Llinhad y dwr lleiaf.

Common. Abundant. Native. Lacustral.

I 568. gibba, Linn. Gibbous Duckweed.

Local. Abundant. Native. Lacustral.

Common, near Cardiff ! etc. J.S. Canal in Aberdare Valley. Ridd. Grangetown, I89I ! U.C.Hb. Duckweeds are used by me every year for teaching purposes, and this species is collected about as frequently as the preceding one. It may, nevertheless, as the actual records suggest, be rare outside the Cardiff area. Ed.

I 569. polyrrhiza, Linn. Greater Duckweed.

Rare. Scarce. Native. Lacustral.

Common in all the reens on the moors, etc. J.S. Blaenycwm, etc. Fl. Rhondda. Very doubtful records; no one else seems to have been able to secure a single specimen in these localities. Ed. Port Talbot and Margam Moors. Ridd.

\section{Wolffia, Hork. 443.}

I 570. Michelii, Schleid. Rootless Duckweed.

Rare. Scarce. Native. Lacustral.

Near Roath Dock, rare. J.S. Abundant in roach ponds, Penarth Road ! 30-5-99. Specimens in U.C.Hb.

\section{Alismaceæ.}

\section{Alisma, Linn. 444.}

1571. Plantago-aquatica, Linn. Greater Water Plantain. Dyfr Lyriad mwyaf.

Common. Abundant. Native. Paludal.

1572. ranunculoides, Linn. Lesser Water Plantain. Dyfr Lyriad bychan.

Local. Frequent. Native. Paludal.

Sketty Bog, near Swansea. L.W.D., B.G. Singleton ; Cromlyn

Bog; Tennant's Canal (credited to Moggridge); near Coedyrallt (Dillwyn). Gutch. Phyt. 1842. p. 180. St. Hilary; Eglwys Brewis; St. Athans. J.S. Llynfach. J.S. (2). Porthcawl. N. Kenfig Pool ! H. and W.C. Oxwich. Miss Nicholl and Miss S. 
Penrice. Miss S. St.-y-Nil ! M.A.D. and V. Neath Canal; Ystradowen; Sully. Ridd. Pendoylan! Whitford Burrows! 1908. Ed.

\section{Elisma, Buchen. 445 .}

I 573. natans, Buchen. Floating Water Plantain. Dyfr Lyriad nofiadwy. Rare. Scarce. Native. Lacustral.

Cromlyn Bog and near Singleton. Gutch. Phyt. I842. p. I80. No recent records.

\section{Sagittaria, Linn. 446.}

1574. Sagittifolia, Linn. Common Arrowhead. Saethlys.

Rare. Frequent. Native. Lacustral, paludal.

"Grew in reens between Bute Road and the canal below St. Mary's Church, and was seen there by me in 1859 , after which it was slowly built out." $R$. Drane. Penrhiwceiber $! E$. and $F$. Very abundant here in 1904. Ed. Talygarn. Miss B. Penllergare! but probably planted. Ed. Margam Moors. Ridd.

\section{Butomus, Linn. 448.}

1576. umbellatus, Linn. Flowering Rush. Engraff, Brwynen flodeuog. Local. Frequent. Native. Paludal.

Crymlyn Bog and Neath Canal. Gutch. Phyt. 1842. p. I80. Canton Common ; Leckwith Common! Sully! Cadoxton! Llanishen. J.S. Ewenny river, near Schwyl! W.C. River Ddaw! D. Llantwit Major! Mrs. Russell. Oxwich Marsh! Miss S. and Mrs. Nicholl. Very fine and abundant in 1908. Ed. Near Leckwith bridge, 12-7-1835. J.E. Resolven; Margam. Ridd. Penmark! Flemingstone Moor ! Grangetown! Penarth Road! Penllergare ! Ed. Apparently confined to the lowlands.

\section{Naiadaceæ.}

\section{Triglochin, Linn. 449.}

1577. palustre, Linn. Marsh Arrowgrass. Saethbenig y gors.

Local. Frequent. Native. Uliginal, paludal.

Crymlyn Bog; Loughor Marsh. Gutch. Phyt. I842. p. I80. Castell Coch. H. Merthyr district. E. and F. St.-y-Nil ! M.A.D. and $V$. Oxwich! Miss $S$. Llanishen. $V$. On mountain between Merthyr and Aberdare. T.H.T. Jersey Marine; Neath; Margam Moors; Merthyr Mawr; Peterston; Ystradowen. Ridd. St. George's ! Cog ! Wrinstone ! near Ogmore Castle ! St. Fagans ! and many other lowland localities. The species almost justifies Storrie's statement :- "common."

1578. maritimum, Linn. Sea Arrowgrass. Saethbenig y morfa.

Local. Abundant. Native. Paludal and littoral.

A typical constituent of the salt meadows, and extending slightly below and above the meadow level. It is found all round the coast from Llanmadoc to Cardiff. It appears to be scarcer about Porthcawl; the following records are therefore noteworthy. Ogmore. Miss $B$. Southerndown. $V$. 


\section{Potamogeton, Linn. 45I.}

1580. natans, Linn. Floating Pondweed. Tafod y ci, Dyfr-llys llydanddail.

Local. Frequent. Native. Lacustral.

Crymlyn Bog. Gutch. Phyt. 1842. p. 180. Leckwith Common; Grangetown Moors. J.S. Kenfig ! $H$. Ewenny ! Miss $B$. Merthyr district. E. and $F$. Gower ! Miss S. Llangenydd; Penllergare; Pantyffynon; Neath; Cowbridge; Aberdare; Peterston. Ridd. St.-y-Nil, I904! Oxwich ! Welsh St. Donats! Ed. Several records have been excluded, on the ground of the probability that they referred to the much commoner polygonifolius.

1581. polygonifolius, Pour. Oblong-leaved Pondweed.

Local. Abundant. Native. Uliginal, lacustral.

As this species has been confused so much with the preceding one, all the available records are given.

Fairwood Common ! and other places in the neighbourhood of Swansea ! W. R. Linton. J. of B. I886. Penrhys, etc. Fl. Rhondda. Cockett; Mynydd Garngoch; Port Talbot. Ridd. Caerphilly ! Eglwysilan ! Llanharran ! Penarth ! Whitford Burrows! Llyn Fach ! ! Ed.

1587. heterophyllus, Schreb. Various-leaved Pondweed. Dyfr-llys amryddail.

Rare. Scarce. Native. Lacustral.

Cromlyn Bog. Gutch. Phyt. I842. p. I80. Reens near Pengam, Grangetown, etc. J.S. Kenfig Pool !! Ed.

varians, (Fryer).

Glamorgan. Miss Armitage. sp. Supp. Top. Bot.

I590. Iucens, Linn. Great Pondweed. Dyfr-llys disclaer.

Rare. Scarce. Native. Lacustral.

Kenfig Pool ! ! 4-7-08. An older record occurs for the same locality. Hb. Motley, Ridd.

1595. perfoliatus, Linn. Perfoliate Pondweed. Dyfr-llys trydwll.

Rare. Scarce. Native. Lacustral.

Near Hensol Lake; St. Fagans. J.S. Penllergare; Peterston. Ridd. Kenfig Pool ! ! Ed.

1596. crispus, Linn. Curled Pondweed. Dyfr-llys crych.

Local. Frequent. Native. Lacustral.

Neath Canal. Gutch. Phyt. 1842. St.-y-Nyl, etc. J.S. Kenfig! H. Cowbridge. J.E. St. Fagans. I. and $V$. Roath Park Lake! V. Mynydd Garngoch ; Crumlin Bog ; Neath ; Glyn Neath ; Porthcawl; Peterston; Reynoldstone. Ridd. Oxwich! Cadoxton Moor ! Flemingstone Moor !' R. Ddaw ! Ed.

I 597. densus, Linn. Opposite-leaved Pondweed. Dyfr-llys tewdws.

Local. Frequent. Native. Lacustral.

Common in district. J.S. A statement with which I agree, notwithstanding the paucity of definite records. Ed. Pontrhondda; Mardy. Fl. Rhondda. Ewenny! Miss B. and M.A.D. Talygarn; 
common. Miss B. Southerndown. M.A.D. Near Dunraven. $V$. St. Fagans. $V$, and $I$. Llandough; Barry to Bonvilstone. Ridd. Llancarfan ! Flemingstone Moors! Cadoxton Moors! Llantwit Major! Penarth! Ed.

1602. pusillus, Linn. Small Pondweed.

Local. Frequent. Native. Lacustral.

Neath Canal. Gutch. Phyt. I842. Common in ditches. J.S. Lower Penarth; Dinas Powys. H. Killay to Pennard ; Pontardulais; Tennant's Canal; St. Athans Road; Hirwaun to Penrhiwceiber. Ridd. Treforest! Kenfig! Ed.

b. tenuissimus, Koch. Brick-pond on Sully Moor!! 23-8-05. Ed.

1605. pectinatus, Linn. Fan-like Pondweed. Dyfr-llys gwrych-ddail. Rare. Scarce? Native. Lacustral.

Canal by Crymlyn Burrows. W. R. Linton. J. of $B . \quad$ I 886. p. 377. Kenfig Pool. Ridd. Roath Park Lake !! V.

I 606. interruptus, Kit.

Local. Abundant. Native. Lacustral.

In enormous quantities in the ponds near Upper Grangetown ! J.S. Now extinct. Loughor; Port Talbot; St. Athans Road ! Ridd. Rifle Range, Penarth Road ! ! I89I. Little roach ponds, Ely Estuary! Flemingstone Moor ! $E d$.

The records for $5_{58} 3$, coloratus, I 584, alpinus, I 594, pralongus, and 1600 , obtusifolius, by Storrie, are excluded pending confirmation by other observers.

\section{Ruppia, Linn. $\mathbf{4 5 2}$.}

1608. spiralis, Hartm. Greater Ruppia. Swansea. Hb. Geldart. Ridd.

I 609. rostellata, Koch. Lesser Ruppia.

Local. Frequent. Native. Lacustral, sub-littoral.

Gower, north coast. E. F. Linton. J. of B. I892. p. 297. Once abundant on site of Dowlais Works, Cardiff, with characters intermediate between those of spiralis and rostellata. Near Red House (on the Ely Estuary ?). J.S. (2). Neath Canal. Gutch. Phyt. 1842. p. I80. Loughor; Port Talbot; Margam. Ridd. Leys ! $E d$.

\section{Zannichellia, Linn. 453 .}

1610. palustris, Linn. Horned Pondweed. Llynwlyddyn corniog.

Local. Abundant. Native. Lacustral.

Common in the lowlands; apparently rare in the uplands. Ponds near Merthyr. T.H.T.

1612. pedunculata, Reichb.

Near Bute Docks!! I89I. U.C.Hb, Ed. 


\section{Zostera, Linn. 454.}

1614. marina, Linn. Common Grasswrack. Ysnoden las-werdd y mor, gwellt y gamlas.

Local. Abundant. Native. Lacustral, littoral.

Frequent. Penarth; Sully Island; Barry; etc. J.S. Flat Holme. J.S. and T.H.T. Trans. C.N.S. Vol. XXII. p. III. Abundant in Oxwich Bay 1 17-4-08, $E d$.

\section{I. Cyperaceæ.}

\section{Eleocharis, R.Br. 458.}

I 622. acicularis, R.Br. Slender Club-rush. Clwp-frwynen leiaf.

The records for this species are all doubtful, but are given to facilitate further search. Town Hill; Port Tennant; Sketty. Gutch. Phyt. I842. p. I8I. Reservoir near Taffs Well; Caerphilly Castle. J.S. Craigafan. Hb. Motley, Ridd. Middleton, Gower. Miss $S$.

1623. palustris, R.Br. Marsh Club-rush. Clwp-frwynen y gors.

Common. Abundant. Native. Paludal.

1624. uniglumis, Reichb.

Cog Rises!! 19-5-08. U.C.Hb. Ed.

1625. multicaulis, Sm. Many-stemmed Club-rush. Clwp-frwynen galafawg.

Local. Frequent. Native. Paludal, inundatal, etc.

Neath Canal; Singleton. Gutch. Phyt. I842. p. I8I. East Moors; Pengam; Llandaff; etc. J.S. Gowerton; Hirwaun; Caerphilly. Ridd. Welsh St. Donat's ! Llanmadoc ! Peterston ! ! Ed.

\section{Scirpus, Linn. 459.}

I 626. pauciflorus, Lightf. Chocolate-headed Club-rush. Clwp-frwynen goch-ddu.

Local. Frequent. Native. Ericetal, uliginal.

Near Kenfig. Marshall and Shoolbred. J. of B. 1902. p. 248. Ystrad Owen. $V$. confirmed by $A . B$. Gower; Crymlyn Bog; Swansea; Aberafan to Baglan. Ridd. Cefn Bryn! U.C.Hb. Ed.

1627. cæspitosus, Linn. Scaly-stemmed Club-rush. Clwp-frwynen y fawnog.

Local. Frequent. Native. Ericetal.

Town Hill, Swansea. Gutch. Phyt. 1842. p. 181. Vale of Neath. $H$. Southerndown. Miss $B$. Merthyr district. $E$. and $F$. Talygarn Bog. V. Fairwood Common; Rhossili Down; Mynydd Garncoch; Glyncorwg; Ystradowen Moor. Ridd. Caerphilly ! Near Tongwynlais! Cefn Bryn! Storrie's statement "every heathy moor in the district" does not imply very wide distribution, even if absolutely correct. $E d$. 
1629. fluitans, Linn. Floating Club-rush. Clwp-frwynen nofiadwy.

Local. Frequent. Native. Lacustral, paludal.

Swansea. E. F. Linton. $J$. of $B$. I 886 . p. II2. Rare. St.-y-Nil; Llyn Fach. J.S. Fairwood Common; Reynoldstone; Cefn Bryn; Crumlin Bog; Welsh St. Donat's; Ystradowen. Ridd.

1630. cernuus, Vahl. Savi's Club-rush.

Local. Frequent. Native. Paludal, inundatal, sub-littoral.

About Swansea. Gutch. Phyt. 1842. p. I8I. Below Pennard Castle! J. Ball; Bot. Gaz. Vol. I. p. I09. Jersey Marine ; Graigafan; Porthcawl. Ridd. Thornhill. M.A.D. and V. Specimen authenticated by A.B. Pitton Cross and other places in Gower I Margam! Kenfig! Ed.

16.31. setaceus, Linn. Bristle Club-rush. Clwp-frwynen fechan.

Local. Frequent. Native. Paludal, inundatal.

Swansea. Gutch. Phyt. 1842. p. I81. Penylan; Wedal; St.-y-Nil, etc. J.S. Vale of Neath ; Penarth. H. Merthyr district. $E$. and $F$. Oxivich. Miss $S$. Pendoylan. I. and $V$. Three Cliffs Bay. Nat.Hb., Ridd. Kenfig! Ogmore Down ! Eglwysilan! Taffs Well ! Pontypridd ! Craig-y-Llyn ! Ed.

1632. Holoschœnus, Linn. Round-headed Club-rush.

Rare. Scarce. Native. Littoral.

East Moors. 17.8.79. J.S. Mr. Chapman, who discovered this habitat, tells me that there were several very fine clumps, and that they grew on the site of the Dowlais Works.

There can be no doubt concerning this record. Braunton Burrows is so near, and shore birds such wanderers, that the migration appears to be quite a natural one.

1633. lacustris, Linn. Common Bulrush. Tost-frwynen.

Local. Frequent. Native. Paludal, lacustral.

Swansea. Gutch. Phyt. I 842 . Rhymney and Ely rivers; St.-y-Nil ! J.S. Sully. H. Ewenny! M.A.D. and V. Oxwich! Miss S. In the Waycock river ! T.H.T. Crumlin Bog; Welsh St. Donat's. Ridd. Often very abundant in the deep quiet waters of the lower reaches of small streams, such as the Ddaw and Ewenny. $E d$.

1634. Tabernæmontani, Gmel. Glaucous Bulrush.

Local. Frequent. Native. Paludal, littoral.

Oxwich Marsh ! D. Fry. J. of B. 1888. p. 57. Ely River; near Cogan Pill ! near Cadoxton Mill. J.S. Salthouse Point; Loughor; Crumlin Bog. Ridd. Whitford Burrows! Estuary of the Ddaw ! Ed.

1638. maritimus, Linn. Sea Club-rush. Clwp-frwynen y morfa.

Local. Abundant. Native. Paludal, littoral.

Extends all round the coast and grows equally well in brackish and fresh water. The so-called varieties need experimental investigation. 
1639. sylvaticus, Linn. Wood Club-rush.

Local. Frequent. Native. Paludal.

Llandaff; Melingriffith; Lisvane; etc. J.S. Llwyn-yr-eos ; St. Fagans. M.A.D. and V. Taffs Well. Nat.Hb., Ridd. Penllergare. Trans. Swansea Sci. Soc. 1895-6. p. 77. Pantyffynon; Killay; Penrhiwceiber; Aberdare. Ridd. Peterston Moors ! and banks of R. Ely! $E d$.

1641. rufus, Schrad. Brown Bog-rush. Corsfrwynen râdd.

Rare. Scarce. Native. Littoral.

Llanmadoc, Gower. June, 1905. V. Specimen examiner by Mr. A. Bennett, who remarked "most southerly record for this plant."

\section{Eriophorum, Linn. 460.}

1643. vaginatum, Linn. Hare's-tail Cotton Grass. Sidan y waun.

Local. Abundant. Native. Uliginal.

No records from the valley of the Ddaw; otherwise distributed over the whole county. Less frequent in the lowlands. Ewenny moors. Miss $B$.

1644. angustifolium, Roth. Common Cotton Grass. Plu giveunydd cul-ddail.

Common. Abundant. Native. Uliginal.

From every district in the county. Dumbath Valley. Miss $B$. Cog Rises! Ed.

1645. Iatifolium, Hoppe. (= paniculatum, Druce.) Downy-stalked Cotton Grass. Plu gweunydd llydan-ddail.

Rare. Scarce. Native. Uliginal.

In great profusion and beauty on a bog called Gors Lwm, on the Banwen, Glyn Neath. E. Lees. Phyt. I843. p. 380 . Rhondda waterfalls; and near-Llyn Fach. J.S. Cefn Bryn. Miss Symons, who records the other two species from the same locality. Penderyn. Ridd.

\section{Rhynchospora, Vahl. $46 \mathrm{I}$.}

1647. fusca, Roem \& Schult. Brown Beak-Sedge.

Rare. Scarce. Native. Uliginal.

On Cromlyn Bog, near Swansea. E. Forster, junior. "It was first discovered on Crumlyn Bog and added to the British Flora by my friend, Edward Forster, Esq., and soon afterwards I found it on the shores of the Lake of Killarney," etc. L.W.D. Mat. Earlier records for this plant in Britain are those of Morison, I699, and Petiver, 1716. First Records of Brit. Flow. Plants, p. 161. No recent records. $E d$.

1648. alba, Vahl. White Beak-Sedge.

Rare. Scarce. Native. Uliginal.

Cromlyn Bog. E. Forster, junior. B.G. Singleton. Gutch. Phyt. I842. p. 18 I. 
Schœnus, Linn. 462.

1650. nigricans, Linn. Black Bog-rush. Corsfrwynen ddû.

Rare. Scarce. Native. Uliginal.

Cromlyn Bog. Westcombe. Phyt. 1844. p. 780. No recent records. Ed.

\section{Cladium, P.Br. 463 ,}

I65I. jamaicense, Crantz. Fen Sedge. Llymdreiniog. Pibfrwynen.

Rare. Frequent. Native. Paludal.

Crymlyn Bog. Lightfoot. J. of B. 1905. p. 299. In one spot only, growing up in the hedge by the side of the Cromlyn Canal, in a marshy spot. E. Lees. Phyt. 1843. p. 380.

Miss E. Vachell is responsible for the section of the flora included in the following genus-Carex. She has worked at the local sedges for five years, and made several interesting additions to the list of species, as well as to the lists of habitats of the rarer forms. The "critical" types have been submitted to Mr. A. Bennett, and the sign!! in this genus will indicate that Miss Vachell or the Editor has collected the plant in the locality to which it is attached, and that the authenticity of the specimen is confirmed by Mr. Bennett. The Editor's contributions will be denoted by $E d$.

\section{Carex, Linn. 465.}

1653. dioica, Linn. Diœcious Sedge. Hesgen ysgar.

Rare. Scarce? Native. Uliginal, ericetal.

Boggy places near Aberdylais waterfall. L.W.D., B.G. Crymlyn and Sketty Bogs. Gutch. Phyt. 1842. p. 18I. Near Penprisc. J.S. Hills between Llwydcoed and Merthyr Tydfil. Ridd.

1655. pulicaris, Linn. Flea Sedge. Chwain Hesgen.

Local. Frequent. Native. Ericetal, uliginal.

Common in bogs. Llanishen ! Caerphilly, etc. J.S. Mead Moor; Oxwich. Miss S. Vale of Neath, etc. $H$. Ystradowen. M.A.D. Pendoylan! I. and E.V. Cwrtyrala!! E.V. St. Bride's! Ewenny Down ! Craig-y-llyn ! Cwm Parc ! etc. Ed. Rhossili; Tankeylake Moor; Whitford Burrows; Pantyffynon; hills above R. Perddyn; Taffs Well ; Llancaiach. Ridd.

1660. disticha, Huds. Soft Brown Sedge. Hesgen lygliw benblydd. Rare. Scarce. Native. Paludal, etc.

Margam Moors. Marshall and Shoolbred. J. of B. 1902, $p$. 250. Fairwater. Nat.Hb., Ridd. Ystradowen ! ! "apparently a form of C. disticha, Huds. A.B." E.V. Cog Rises, I908!! Ed. Peterston Moor. Ridd.

1661. arenaria, Linn. Sea Sedge. Hesgen arfor, Hesgen y tywod.

Common. Abundant. Native. Glareal, littoral. 
1662. teretiuscula, Good. Lesser Panicled Sedge. Hesgen rafunog leiaf. Rare. Scarce. Native. Paludal, uliginal.

Quaker's Yard; rare. J.S. Sketty Bog. Hb. Brit. Mus., Ridd.

1664. paniculata, Linn. Greater Panicled Sedge. Hesgen rafunog fwyaf. Local. Frequent. Native. Paludal, uliginal.

Crymlyn Bog. Lightfoot. J. of $B$. I905. p. 30I. Swansea. E. F. Linton. J. of B. I886. p. I12. Swampy wood, bordering Margam marshes. Marshall and Shoolbred. J. of B. 1902. p. 250. Glanrhyd. Trans. Swansea Sci. Soc. 1893. p. 27. Penllergare. Trans. Swansea Sci. Soc. 1895-6. p. 77. Pontypridd; Glyncorwg. J.S. Woods near Cwmparc; very variable. $N$. Vale of Neath; Sully. H. Ystradowen!! M.A.D. and E.V. "intermediate between the type and the var. simplicior, Anders. A.B." Pendoylan. I. Llangeinor, 1892 ! near Kenfig River ! Llanharran! Lisvane ! Ed. Fairwood Common; Rhossili ; below Craig-y-llyn; Neath ; Tennant's Canal; Aberdare; Llancaiach. Ridd.

\section{Boenninghauseniana $($ Weihe $)=C$. paniculata $\times$ remota.}

Moors near Cwmparc. "The sedges in this marshy spot would well repay closer study, as several species are found within a small space and the plants exhibit great variability." $N$.

1665. vulpina, Linn. Great Sedge. Hesgen dywysenog fwyaf.

Common. Abundant. Native. Paludal, inundatal.

1667. muricata, Linn. Greater Prickly Sedge.

Local. Abundant. Native. Pascual, glareal, etc.

Too common as an aggregate for record of the separate localities.

There are apparently three segregates now recognised, though it is very doubtful whether they are worthy of separation, as they sometimes appear to be scarcely recognisable, even by the expert.

a. C. contigua, Hoppe. St. Fagans!! Penarth Road! Pendoylan! E.V. Penarth! Ed. Penylan. Ridd. This is the commonest form in Glamorgan. C. Leersii appears to be intermediate between it and C. divulsa.

b. C. Leersii, F. Schultz. (= muricata, var. pseudo-divulsa, Syme). Swansea. W.R. Linton. Rep. B.E.C. 1889. p. 272. This was referred to $C$. divulsa by A. Bennett. Pyle; Llantwit Major to Monknash; Aberdare. Ridd. Some of these records may belong to 1668 .

c. C. Pairaei, F. Schultz. Pyle. E. S. Marshall. J. of B. 1907. p. I63. Rhossili. Ridd. The Pyle plant was placed under C. Leersii by Kükenthal.

These forms should be submitted to the test of pure culture, under definite environment.

1668. divulsa, Good. Grey Sedge.

Local. Scarce. Native. Septal, sylvestral, etc.

Swansea.. 31-5-1888. W. R. Linton. Ex. C. Report. 3 I3. 1890 (1891). Swansea. 31-8-1888. E. F. Linton. sp. Notes furnished by $A . B$. Leckwith. $N$. Castell Coch to Black Cock ! 
Near Fairwater! Pendoylan ! ! E.V. Gigman! I. B. Pole-Evans. Aberthaw to St. Athans Road ! Lavernock ! ! Ed. St.-y-Nyl ; Llandaff. Ridd.

1669. echinata, Murr. (= stellulata, Good). Little Prickly Sedge. Hesgen seraidd, Hesgen bigog leiaf.

Local. Abundant. Native. Paludal.

Too frequent in the uplands for separate citation of the records. The records for the lowlands only are given. Llanishen; Pengam Moors. J.S. Gower. Miss S. Ystradowen. M.A.D. Pendoylan! E.V. and 1 . Talygarn Bog ! E.V. Singleton Marsh. Gutch. Phyt. 1842. p. 181. Llantrithyd; Llandaff. Ridd.

670. remota, Linn. Distant-spiked Sedge. Hesgen anghyfagos.

Local. Abundant. Native. Inundatal, etc.

Common in the lowlands, rarer in the uplands. Moors near Cwmparc. N. Merthyr district. $E$. and $F$. Llantrissant ! Ed.

1671. axillaris, Good. (= remota $\times$ vulpina.)

Lavernock Road !! 3-6-1905. E.V.

I676. curta, Good. White Sedge. Hesgen benwen.

Rare. Frequent. Native. Paludal.

Crumlyn and Sketty Bogs. J. Woods, junior. B.G. Hirwaun Common. J.S. Llancaiach ! $M r$. J. Evans, Merthyr district. $E$. and $F$. Treorchy. N. Pendoylan ! ! Miss Shaw, E.V., and Ed. Llynfach. Ridd.

1677. ovalis, Good. Oval-spiked Sedge. Hesgen hirgylchaidd.

Local. Frequent. Native. Paludal.

Scarcely common and abundant, but widely distributed. Swansea. E. F. Linton. $J$. of $B$. 1886. p. II2. Frequent. Cadoxton Moors! etc. J.S. Fairwater. Nat.Hb., Ridd. Pendoylan!! E.V., I., and Ed. Caerphilly! Ystradowen! E.V. Mead Moor; Gower. Miss S. Merthyr district. E. and F.sp.! Craig-y-llyn! Llanharan! Ed.

1681. Hudsonii, Ar. Benn. (= elata, All.). Tufted Sedge.

Rare. Scarce. Native. Paludal.

Kenfig Pool. Mr. Motley, L.W.D. Mat. Crumlin Bog ; Flemingstone Moors. Ridd.

$\times$ acuta. Crumlin Bog. Ridd.

$\times$ Goodenowii. Flemingstone Moors. Ridd.

1682. acuta, Linn (=gracilis, Curt.). Slender-spiked Sedge. Hesgen eiddil-dywysenog.

Rare. Scarce. Native. Paludal.

Schwyl, Ewenny river!! I903. E.V., M.A.D., and I. Ely to St. Fagans. Nat.Hb., Ridd. Flemingstone Moors-banks of the Ddaw !! 1905. Ed.

\section{d. gracilescens, Almq. \\ Ewenny. Ridd.}

$\times$ Goodenowii. Crumlin Bog. Ridd. 
1687. Goodenowii, J. Gay. Common Sedge.

Common. Abundant. Native. Paludal, pratal.

var. recta, (Fleischer). Llwydcoed, Aberdare. Ridd. Bot. Exch. Club Rep. 1903. p. 28. Port Talbot. Ridd.

var. juncea, Fries. Merthyr Tydfil. J. Evans, sp.!! Crumlin Bog; Aberdare. Ridd. The name juncea (1842) is one year older than juncella (1843). A.B.

var. melæna, (Wimm.). Merthyr Tydifi. J. Evans, sp.!! Margam Moors; Aberdare. Ridd.

1688. flacca, Schreb. (=glauca, Scop.). Glaucous Selge. Hesgen oleulas wyrgamddail.

Common. Abundant. Native. Pratal, paludal.

1690. limosa, Linn. Narrow-leaved Mud Sedge. Hesgen eurwerdd.

Rare. Scarce. Native. Uliginal.

On Cromlyn and Sketty Bogs, near Swansea. Mr. E. Forster, junior. B.G. No recent records.

1695. montana, Linn. Mountain Sedge.

Rare. Abundant. Native. Ericetal, pascual.

Ewenny Downs!! Ridd., E.V., and Ed. J.of B. 1905. p.217.

I696. pilulifera, Linn. Round-headed Sedge. Hesgen bengron.

Local. Frequent. Native. Ericetal.

Pendoylan !! E.V. and $I$. Llanishen ! E.V. Cwmparc. $N$. Horton; Oxwich. Miss S. Glyn Corwg. Nat.Hb., Ridd. St. Bride's and Ewenny and Ogmore Downs! Ed. Pitton Green ; Hirwaun Common ; above Aberpergwm ; Mountain Ash ; Caerphilly Common! Llancaiach. Ridd.

1698. verna, Chaix. (= caryophyllea, Latourr:). Vernal Sedge. Hesgen gynnar.

Common. Abundant. Native. Pascual.

It flowers so early-with the cowslips-that it is apt to be overlooked.

1700. pallescens, Linn. Pale Sedge.

Local. Frequent. Native. 'Paludal, sylvestral.

Near Glynneath. E. F. Linton. J. of B. 1892. p. 297. Llwydcoed. I888. E. F. Linton. sp. A.B. Merthyr Tydfil. J. Evans, $s p .1 !$ Llantrissant! C.T.V. Pendoylan! E.V. Roath Park Lake. $N$. Merthyr district. E. and F. Ynysygwas. Hb. Motley, Ridd. Aberdare; Mountain Ash; Radyr; Lisvane. Ridd.

1701. panicea, Linn. Pink-leaved Sedge. Hesgen bennigen-ddail.

Common. Abundant. Native. Paludal, pratal.

No records for the valleys of the Ogmore and Ddaw. 
1706. pendula, Huds. Great Pendulous Sedge.

Local. Frequent. Native. Sylvestral.

Frequent. Leckwith; Llandough; etc. J.S. Penllergare. Trans. Swansea Sci. Soc. I895-6. p. 77. Glanrhyd. Trans. Swansea Sci. Soc. I893. p. 27. Leckwith. M.A.D. and E.V. Porthkerry ; Cwrtyrala, E.V. Leckwith Quarry. U.C.Hb. 1879. Glyn Neath to Resolven; Wenvoe. Ridd.

1707. strigosa, Huds. Loose-spiked Wood Sedge.

Rare. Frequent? Native. Sylvestral.

Cromlyn and Sketty Bogs. Gutch. Phyt. I842. p. I81. Cwrtyrala ! ! 1904. E.V. Glanrhyd? Trans. Swansea Sci. Soc. 1893-4. p. 27.

I709. sylvatica, Huds. Pendulous Wood Sedge. Hesgen dibynaidd y goedwig.

Common. Abundant. Native. Sylvestral.

1710. lævigata, Sm. (= helodes, Link.). Smooth-stalked Sedge. Hesgen ylfinog lefn.

Local. Frequent. Native. Paludal, sylvestral.

Quaker's Yard. Mr. E. Forster, junior, B.G. Common about Aberafon. Mr Motiey, L.W.D. Mat. Coed Coesau Whips. Nat.Hb., Ridd. Oystermouth. J. Woods. Phyt. I850. p. I061. Thornhill ! ! M.A.D. and E.V. Pendoylan । E.V. Aberafon. G.T. Ystalyfera; Neddfechan Gorge; Taffs Well; Caerphilly hill range. Ridd.

1711. binervis, Sm. Green-ribbed Sedge. Hesgen deulasnod.

Local. Abundant. Native. Ericetal.

Common on upland moors in Glamorgan. Ridd. J. of B. 1905. p. 217. Rare in the lowlands apparently. Pendoylan ! E.V. 15-6-1904. Pitton Cross! 12-8-08. Ed.

1712. distans, Linn. Distant-spiked Sedge. Hesgen anghysbell.

Local. Frequent. Native. Littoral, sub-littoral.

All inland records are almost certainly erroneous and are therefore excluded. Near Gowerton. E. F. Linton. J. of $B$. 1892. p. 297. Barry Island. I. Llanmadoc ! ! Penarth Road ! E.V. Llanrhidian; Loughor (Hb. Motley); Port Talbot; Aberthaw; St. Athans Road; Pengam Marshes. Ridd. Valley below Pennard Castle ! Leys, 1905 ! Cogan Pill, 1899!! Sully Island, I908! ! Ed.

1714. fulva, Host: (= Hornschuchiana, (Hoppe.). Tawny Sedge Hesgen dywell-felen.

Local. Frequent. Native. Paludal.

Near Clyne Moor. W. R. Linton. J. of B. I886. p. 377. Whitchurch. Nat.Hb., Ridd. Merthyr Tydfil. Mr.J. Evans, sp.!! Ystradowen !! Pendoylan !! E.V. Mynydd Garngoch; Gowerton Common; Ystalyfera; hills above R. Perddyn; Penderyn ; Hirwaun; Whitchurch; Lisvane. Ridd.

xanthocarpa, $($ Degl. $)=($ fulva $\times$ flava? $)$

Ystradowen !! 7-7-1904. E.V. 
17I 5. extensa, Good. Long-bracteated Sedge. Hesgen hiriain.

Local. Frequent. Native. Sub-littoral.

Near Neath. Westcombe. Phyt. 1844. p. 780. Three Cliffs Bay, Gower. Ridd. J. of B. I904. p. 305. Llanmadoc ! ! 1905. E.V. Whitford Point; Crumlin Burrows; Porthkerry. Ridd Leys !! Ely Estuary ! Ed.

\section{b. pumila, Anders.}

Leys!! 1905. Ed.

1716. flava, Linn. Yellow Sedge. Hesgen felen.

Common. Abundant. Native. Paludal.

a. lepidocarpa, (Tausch.) Bonvilstone. Ridd.

b. minor, Towns. (= oedocarpa, And.) Whitchurch. Ridd. Ystradowen ! ! E.V.

\section{c. Ederi, Retz.}

Swansea. E. F. Linton. J. of B. I886. p. I12. Whitchurch (var. elatior, And.), Oxwich (var. cyperoides, Marss.). Ridd. Aberafan; Port Talbot. Ridd. Kenfig!! U.C.Hb., Ed., and N.

All these flava records must be accepted with caution. Experimental work is required to supplement the incomplete morphological studies which have hitherto been made.

1718. hirta, Linn. Hairy Sedge. Hesgen flewog.

Common. Abundant. Native. Paludal, pratal, etc.

b. hirtiformis, (Pers.)

St.-y-Nil!! Pendoylan ! E.V. Margam Moors ; Port Talbot ; Merthyr Tydfil, Ridd.

\section{Pseudo=cyperus, Linn.}

Rare. Scarce. Native. Paludal.

Crymlin Bog. Lightfoot. J. of B. 1905. p. 30I. St.-y-Nil ! ! 1904. M.A.D. and E.V. St.-y-Nil, 1908. Ridd.

1720. acutiformis, Ehrh. (= paludosa, Good.) Lesser Pond Sedge. Hesgen ganolig-dywysenog.

Local. Frequent. Native. Paludal.

Margam Marshes. Marshall and Shoolbred. J. of B. 1902. p. 250. Fairwater. Nat.Hb., E. F. Linton. Marsh between Ely and St. Fagans. Nat.Hb., Ridd. Near Penylan! Roath Park ! ! St.-yNil ! Lavernock Road ! E.V. Llanmaes. I. B. Pole-Evans, sp.! Crumlin Bog; Neath; Tennant's Canal; Baglan Marshes; Ogmore Castle (with var. Kochiana $(D C)$.$) ; Aberdare; Welsh St. Donats;$ Peterston; Ystradowen Moor. Ridd. Cog Rises 1 ! Peterston Moor ! ! Kenfig River ! ! Ed.

172I. riparia, Curtis. Greater Pond Sedge. Hesgen braff-dywysenog. Common. Abundant. Native. Paludal.

Much more common than the last species in the lowlands, often forming a dense and comparatively pure formation along the margins of reens. 
1722. rostrata, Stokes. Bottle Sedge. Hesgen chwysigenaidd ylfinfain Local. Abundant. Native. Paludal.

Too widespread for detailed citation. Ascends to the shore of Llynfach, and is found in the lowlands at Ystradowen and Pendoylan.

b. elatior, (Blytt). Llancaiach. Nat.Hb., Ridd. fide E.F.L. Concerning a specimen from Ystradowen (E.V.), Mr. Bennett reported"A pretty form, apparently sterile-I have not seen a specimen, but it appears to answer to the var. nusticana, Laest."

1724. vesicaria, Linn. Bladder Sedge. Hesgen chwysigenaidd berdywysennog.

Rare. Scarce. Native. Paludal.

Near Cardiff, common. J.S. Marsh between Ely and St. Fagans, 1908. Nat.Hb., Ridd. Aberdare. Ridd. Hirwaun Ponds, 1909! Peterston Moors!! 12-7-09. Ed.

\section{Gramineæ.}

\section{Phalaris, Linn. 470.}

1738. arundinacea, Linn. Ribbon Grass.

Local. Abundant. Native. Paludal.

Fairly common in the lowlands, apparently rare in the hill districts.

\section{Anthoxanthum, Linn. 471.}

1739. odoratum, Linn. Sweet-scented Vernal-Grass. Melynwellt perarogl y gwanwyn.

Common. Abundant. Native. Pascual, pratal, sylvestral, etc. This species is very remarkable for the great variety of its habitats.

\section{Alopecurus, Linn. 473.}

1742. myosuroides, Huds. Slender Fox-tail Grass.

Local. Frequent. Native? certainly often introduced. Agrestal.

Cathays Park. V. Port Talbot; Merthyr Dyfan; Pengam salt-marshes. Ridd. Penarth ! I890; Southra farm, Dinas Powys! 1905. Ed.

1743. fulvus, Sm. Orange-anthered Fox-tail Grass.

The records by Storrie:-Grangetown, Leckwith, etc., require confirmation. I have searched these localities many times. Ed.

1744. geniculatus, Linn. Bent-stemmed Fox-tail Grass. Rhon-wellt y cadnaw cymmalog.

Common. Abundant. Native. Paludal. 
1745. bulbosus, Gouan. Tuberous Fox-tail Grass.

Local. Abundant. Native. Littoral, inundatal.

Cardiff Marshes. Rev. J. Lightfoot, B.G. Near Gowerton. E. F. Linton. J. of $B$. 1892. p. 297. Upper Grange and near Rumney. J.S. Leckwith Moors. Ridd. This grass is very abundant in its favourite habitat, which is slightly above that adopted by Juncus Gevardi. It occurs often in slight hollows where the salt water of very high tides collects, and as a practically pure formation, recognisable from a distance by its dark colour. One may see acres of land, as at Pengam, covered with it. It occurs, however, here and there, in meadows at a still higher level, seldom, if ever, flooded by salt water. These places may indicate a real rise in the land surface. Rhymney Estuary ! Taff Estuary ! Ely Estuary ! Sully Moors 1 Porthkerry! Leys ! Ed. Its occurrence in the Loughor Estuary suggests that it may be found all round the coast.

1746. pratensis, Linn. Meadow Fox-tail grass. Rhon-wellt y cadnaw y weirglawdd.

Common. Abundant. Native. Pratal.

Though common and abundant in the sense in which these terms have been defined, this valuable grass is rather scarce from the point of view of the farmer. Its constant occurrence in a field may be accepted as satisfactory evidence of the high quality of the soil.

\section{Milium, Linn. 474 .}

1748. effusum, Linn. Wood Millet Grass. Miled-wellt.

Local. Frequent. Native. Sylvestral.

Resolven. E. F. Linton. J. of B. 1892. p. 297. Llandaff ; Swanbridge ; Dinas Powys ; J.S. Wood behind Ely. I90氵. Nat.Hb., Ridd. Lavernock. $H$. St. Fagans; Llanedeyrn. V. Margam ; Mountain Ash; Forest Wood, Ystradowen. Ridd. Cwrtyrala, 1899 ! U.C.Hb., Ed.

\section{Phleum, Linn.}

1750. pratense, Linn. Timothy Grass. Rhon-wellt y gath cyffredin. Common. Abundant. Native. Pratal, pascual.

b. nodosum, (Linn.) Widespread in the lowlands. Aberdare. Ridd. c. stoloniferum, Bab. Port Eynon. Ridd.

1752. arenarium, Linn. Sand Timothy Grass.

Local. Abundant. Native. Glareal, littoral.

Mumbles Road. Gutch. Phyt. I842, p. I81. Cardiff Docks and E. Moors. J.S. Llanmadoc. V. Burrows of Gower 1 Miss S. Briton Ferry; Sker; Aberafan. Ridd. Porthcawll I89i. U.C.Hb. Kenfig $\mid E d$. 


\section{Agrostis, Linn. 477 .}

1754. setacea, Curtis. Bristle-leaved Bent Grass.

Local. Abundant. Native. Ericetal, pascual, glareal.

Cefn Bryn, Gower 1 R. Withers. Bot. Gaz. Vol.II. p. 277.

Newton Down. Woods. Phyt. 1850. p. I061. Waun, near Pencoed and St. Mary Hill Down! J.S. Welsh St. Donat's ; Caerphilly Mountain! $V$. Cefn Bryn! Frog Moor ! Cliffs, Oxwich to Port Eynon! Ridd. Port Eynon to Ramsgrove ! Ed. S. Cornely ; Ewenny Down I Stalling Down; coast near St. Athan's Road. Ridd. Caerphilly to Taff's Well ! Old Castle Down! Occurs almost invariably on the mountain limestone and then is often the dominant species. $E d$.

1755. canina, Linn. Brown Bent Grass. Meus-wellt y ci.

Local. Abundant. Native. Pascual, ericetal.

Caerphilly; Llanishen; Wedal. J.S. Gowerton Common ; Mynydd Garncoch ; Crumlin Bog; Ystalyfera ; Hirwaun Common ; Stalling Down; Welsh St. Donats; Port Talbot; Llancaiach. Ridd. Ogmore Down! Old Castle Down! Ewenny Down! Oxwich to Port Eynon! generally accompanied by A. setacea in these localities. Ed.

1756. palustris, Huds. Marsh Bent Grass. Meus-wellt gwyn y waun.

Common. Abundant. Native. Pratal, pascual, etc.

I am quite unable to decide as to the validity of the segregates which have been formed from this species. There appear to be many distinct forms, and some, at least, like stolonifera, can apparently be always separated from the others without difficulty. Much further study-histological and experimental, as well as morphologicalis necessary before a satisfactory account can be rendered of this aggregate. Mr. Riddelsdell gives localities for six varieties.

1757. vulgaris, With. (=tenuis, Sibth.). Common Bent Grass. Meuswellt addfain.

Common. Abundant. Native. Pascual, ericetal.

Occasionally, as in parts of Gower, it forms the bulk of the vegetation in poor pastures.

\section{Calamagrostis, Adans. 479.}

I 760. epigeios, Roth. Wood Small Reed. Corsen y sychdir.

Local. Frequent. Native. Sub-littoral, paludal, sylvestral.

Between the Ferry and Port Tennant. Gutch. Phyt. I 842 . p. 182. Near Loughor. L.W.D. Mat. Oxwich ! Miss S. Sully Island ! $V$. Porthcawl Sands; the Leys; Porthkerry. Ridd. Horton to Oxwich! Pontyclun! Ed.

\section{Gastridium, Beauv. 480.}

1762. australe, Beauv. (= lendigerum, Gaud.) Awned Nitgrass.

Rare. Scarce. Colonist? Agrestal, etc.

Penarth. J. Woods. Phyt. 1850. p. I06r. E. Moors. $M r$. Chapman, who says that his specimens did not occur on the ballast. Penarth and Cardiff; on the ballast. J.S. The proximity of these localities to the docks, and the absence of recent records, suggest that it was introluced with ballast, obtained a temporary foothold, but failed to establish itself. 
Ammophila, Host. 483 .

1767. arundinacea, Host. Marram Grass. Morhesg, Merydd, Cors-wellt y tywod.

Common. Abundant. Native. Glareal, littoral.

\section{Aira, Linn. 485 .}

1770. caryophyllea, Linn. Silvery Hair-Grass. Brigwellt ariannaidd. Common. Abundant. Native. Glareal, pascual.

1771. praecox, Linn. Early Hair-grass. Brigwellt y gwanwyn.

Common. Abundant. Native. Glareal, pascual. Found in all districts.

\section{Weingærtneria, Bernh. 486.}

1772. canescens, Bernh. Grey Hair-grass.

Rare. Abundant. Denizen. Glareal, littoral.

Aberavon, within a mile of the Docks. July, 1904. Ridd. $J$. of $B$. 1906. p. 69. This appears to be a clear case of successful immigration. Ed.

\section{Deschampsia, Beauv. 487.}

1773. caspitosa, Beauv. Tufted Hair-grass. Brigwellt mawnog. Common. Abundant. Native. Paludal, pratal, etc.

b. brevifolia, Parnell. Ystalyfera; Peterston. Ridd.

1776. flexuosa, Trin. Heath Hair-grass. Brigwelt gwyrgam mynyddawl Common. Abundant. Native. Ericetal, sylvestral.

Holcus, Linn. 488 .

1777. mollis, Linn. Creeping Soft-grass. Maswellt rhedegog.

Local. Frequent. Native. Pratal, etc.

Neath Canal. Phyt. Gutch. 1842. p. 182. Penarth; Pencoed; Ewenny Bridge; etc. J.S. Merthyr district. E. and $F$. St. Fagans; Pwllypant. V. Llandough ! Cwrtyrala ! Nelson! Llanfabon ! Ed. Frequent, especially in the Taff and Rhymney Valleys. Ridd.

1778. lanatus, Linn. Yorkshire Fog. Maswellt sypwraidd.

Common. Abundant. Native. Pratal, etc.

Trisetum, Pers. 489.

1779. pratense, Pers. Yellow Oat-Grass. Ceirch-wellt melynaidd.

Common. Abundant. Native. Pascual, etc.

Often the commonest grass apparently in pastures on the Lias.

Very abundant in the Vale of Glamorgan. No records from the coal measures. 


\section{Avena, Linn. 490.}

780. pubescens, Huds. Downy Oat-Grass. Ceirch-wellt mânbluaidd. Local. Frequent. Native. Pascual, rupestral.

Horton. Miss $S$. Cold Knap; many plants with leaves and sheaths glabrous." $N$. Creigiau. $V$. Lower Grange. J.S. Rhossili ; cliffs of Gower in several places; Swanbridge; Morlais Castle. Ridd. Sully ! I 899 onwards; St. Bride's ! Southerndown Road! Ewenny Down! Ed.

1781. pratensis, Linn. Glabrous Oat-Grass. Ceirch-wellt culddail. Rare. Scarce. Native. Pascual. Porthkerry; Swanbridge. Ridd.

1783. fatua, Linn.

Rare. Scarce. Colonist or alien. Agrestal.

Occasionally in cornfields. J.S. Cardiff Docks; Riverside. $H$. Creigiau. V. Crumlin Burrows; Port Talbot; Graigafan; Barry ; Aberdare; Hirwaun. Ridd. I have no note of its occurrence in Glamorgan, and doubt whether it succeeds in maintaining its position anywhere in this county. Ed.

\section{Arrhenatherum, Beauv. 491.}

I784. avenaceum, Beauv. (= elatius, Mert \& Koch.) False Oat-Grass. Maswellt ceirchaidd.

Common. Abundant. Native. Septal, etc.

b. nodosum, Reichb. Almost equally common and abundant.

\section{Sieglingia, Bernh. 493.}

I786. decumbens, Bernh. Decumbent Heath-Grass. Gweun-wellt gorweiddiog.

Common. Abundant. Native. Ericetal, etc.

\section{Phragmites, Trin. 404 .}

1787. communis, Trin. Common Reed. Corsen gyffredin.

Common. Abundant. Native. Paludal.

A typical plant of the lowland reens, ponds, and slow streams. No records from the uplands.

\section{Cynosurus, Linn. 496.}

1789. cristatus, Linn. Crested Dog's-tail Grass. Rhon-wellt y ci cribog.

Common. Abundant. Native. Pascual. Often the commonest grass in pastures. 
Koeleria, Pers. 497.

I791. cristata, Pers. Crested Hair-Grass. Brigwellt cribog.

Local. Frequent. Native. Pascual, glareal, etc.

Llanishen; Caerphilly ! Pontypridd. J.S. Cliffs of Gower. Miss S. Gileston. M.A.D. and V. Leys! I. I899 to I907. Ed. Pennard to Broughton Burrows. Ridd. Ewenny Down! St. Bride's Major! Barry Island! Ed.

gracilis, Pers. Whitford Burrows; Dunraven; Southerndown ; St. Bride's Major. Ridd. One or two more of the localities under cristata will probably prove to be habitats for this type, which is a very distinct one, and of which I have a specimen from Brean Down, Somerset. U.C.Hb., I 899. Ed.

\section{Molinia, Schrank. 498.}

1792. varia, Schrank. Purple Melic-Grass. Melic-wellt rhuddlas.

Common. Abundant. Native. Ericetal, etc.

Comparatively scarce in the lowlands, and seldom forming the chief vegetation, as it so often does on the high-lying moors of the adjacent county of Brecon.

\section{Catabrosa, Beauv. 499.}

1793. aquatica, Beauv. Water Whorl-Grass. Brigwellt dyfrdrig. Rare. Scarce. Native. Paludal.

Near the Vitriol Works, E. Moors; Pengam Moors. J.S. The plants were found by $M r$. Chapman, who remembers the circumstances very well. Now extinct.

\section{Melica, Linn. 500.}

1795. uniflora, Retz. ( = nutans, Linn.). Wood Melic-Grass. Melicwellt y goedwig.

Local. Abundant: Native. Sylvestral.

Too frequent in the Vale of Glamorgan for citation of the records. Merthyr district. E. and F. Llanrhidian; Nicholaston Woods ; Ystalyfera ; Melincourt and Neddfechan Glens. Ridd.

\section{Dactylis, Linn. 50I.}

1796. glomerata, Linn. Cock's-foot Grass. Byswellt garwaidd, Troed y ceiliog.

Common. Abundant. Native. Pratal, etc.

\section{Briza, Linn. 502 .}

1798. media, Linn. Common Quaking Grass. Crydwellt, Eigryn, Gwenith ysgyfarnog.

Common. Abundant. Native. Pascual, pratal.

Very common on the limestones, perhaps rarer on the coal measures, for which the only definite records are Gowerton, Rhigos, and Resolven. 


\section{Poa, Linn. 503.}

1800. annua, Linn. Annual Meadow-grass. Gweun-wyllt blynyddawl. Common. Abundant. Native. Agrestal, glareal, viatical, etc.

1801. bulbosa, Linn. Bulbous Meadow-grass.

Rare. Scarce. Native. Glareal.

Near Barry!! U.C.Hb. I907. Viviparous, like the continental form. Becoming extinct, I fear. When first discovered, there were very many plants, spread over a considerable area. Ed.

1807. nemoralis, Linn. Wood Meadow-grass. Gweun-wellt y goedwig. Local. Frequent. Native. Sylvestral, rupestral.

Coed Mawr; St. Fagans; Coed Mwstwr; Pencoed. J.S. Merthyr Mawr. Miss B. Gileston. M.A.D. Merthyr district. $E$. and $F$. Reynoldstone; Llandaff; Coed-y-gores. Ridd. Wood near Ogmore Down!! Wall near Southerndown Road Station!! Penarth !! At least two types occur in Glamorgan. Mr. Bennett reported on the Penarth specimens- "coarctata, (Gaud), or very near it."

1808. compressa, Linn. Flat-stemmed Meadow-grass. Gweun-wellt cyngwasgedig.

Local. Frequent. Native. Glareal, rupestral.

Barry. V. Vach. Herb. Walls and embankments at Penarth!! Swanbridge ! Ed. Oxwich; Horton; Port Talbot; Cadoxton ; Aberdare ; Dowlais ; Cardiff ; Caerphilly. Ridd.

I 8 I o. pratensis, Linn. Smooth Meadow-grass. Gweun-wyllt llyfn.

Common. Abundant. Native. Pascual, glareal, etc.

b. subcœrulea, (Sm.). Common and abundant in drier situations than those affected by the type.

c. angustifolia, (Linn.). Frequent. Graigafan; Port Talbot; Hirwaun; Cardiff. Ridd.

181 2. trivialis, Linn. Rough Meadow-grass. Gweun-wyllt lledarw.

Common. Abundant. Native. Pratal, sylvestral, etc.

\section{Glyceria, R.Br. 504.}

1813. fluitans, R.Br. Floating Meadow-grass. Gweun-wyllt nawf. Common. Abundant. Native. Lacustral, paludal.

fluitans $\times$ plicata. Widespread, found in most lowland districts apparently.

1814. plicata, Fr. Folded-leaved Meadow-grass.

Local. Frequent. Native. Paludal.

Too frequent in the lowlands for citation of the records. Aberdare; Penrhiwceiber; Llantrisant. Ridd. Llanharry!! Ed.

depauperata, Crépin. Port Talbot. Marshall and Shoolbred. $J$. of B. 1902. p.250. Llangenydd; Ystalyfera. Ridd. 
1815. aquatica, Sm. Reed Meadow-grass.

Local. Frequent. Native. Paludal.

Crymlyn Bog; and banks of Neath Canal. Gutch. Phyt. I842. p. I82. Lower Penarth! Sully! Cadoxton! etc., frequent. J.S. Park Mill ! Loughor; Jersey Marine; Resolven; Port Talbot; Margam ; Cadoxton. Ridd. Ewenny river banks! banks of R. Ddaw from Beaupris to St. Athan's Road! Rivers Waycock! and Keyson! Kenfig ! A very typical grass of the reens, margins of slow deep streams, and backwaters on rich alluvium. Ed.

1 81 6. maritima, Mert \& Koch. Creeping Sea Mearlow-grass. Gweunwellt arfor.

Local. Abundant. Native. Littoral.

Often very abundant on the salt muds of our estuaries from the Rhyminey to the Loughor. It extends below the level of Festuca rubra, and is often associated with Aster Tripolium and Salicornia.

1817. distans, Wahlenb. Reflexed Meadow-grass.

Local. Frequent. Native. Sub-littoral.

Llandwr Marsh. Gutch. Phyt. I842. p. I82, Cardiff, common. J.S. Tennant's Canal side. Nat.Hb. 1834. Conway Collection. Ely Estuary. V. Llanmadoc; Loughor; Port Talbot; Margam; St. Athan's Road; Porthkerry. Ridd. Ely estuary at many points ! Penarth !! Ed.

'r18. Borreri, Bab. Borrer's Meadow-grass.

Rare. Frequent? Native. Sub-littoral.

On the mud dredged from the shore at Cardiff Docks, growing with G. distans. July, I904. G. C. Druce. Rep. Bot. Exch. Club. I904. p. 39.

\section{Festuca, Linn. $5^{0} 5$.}

1819. procumbens, Kunth. Procumbent Meadow-grass.

Rare. Frequent? Native. Littoral.

Cardiff Docks. V. Cardiff; Pengam Marshes. Ridd.

1820. rigida, Kunth. Hard Meadow-grass. Gweun-wyllt anhyblyg. Common. Abundant. Native. Glareal.

I 82 r. rottbellioides, Kunth. Dwarf Meadow-grass. Corwenith-wellt y morfin.

Local. Frequent. Native. Littoral.

Flat Holme. Lightfoot. J. of B. 1905. p. 299. Singleton. Gutch. Phyt. I 842. p. 182. Penrice, in sandy meadows. Turton. L.W.D. Mat. Penarth; E. Moors; Cold Knap. J.S. Pennard to Burry Holm; Porthcawl; St. Donats to Nash Point; Aberdare. Ridd. Pennard Castle, abundant and luxuriant, 1908 ! All records east of Nash Point must be regarded as doubtful. Ed. 
I 822. uniglumis, Soland. (= membranacea, Druce.) Single-glumed Fescue-grass. Peisg-wellt uncib.

Local. Frequent. Native. Littoral.

Sands near Swansea. J. Ball. Bot.Gaz. Vol. I. p. Iog. Common on sandhills, and found plentifully on those of Aberafan and Porthcawl. Mr. Motley. L.W.D. Mat. Briton Ferry. Lightfoot. J. of B. 1905. p. 301. Burry Holm, I904; near Southerndown, 1907. Nat.Hb. ! Ridd. Llanmadoc, Gower. V. sp. !

1824. Myuros, Linn. Mouse-tail Fescue-grass. Peisg-wellt y fagwyr. Local. Frequent. Native. Glareal, rupestral.

Near Aberdare, I902. Nat. Hb. Ridd. North Road and Barry Railway bank, Cardiff; Cefn On. V. Peterston; Cardiff Docks. Ridd. Sully ! Lower Penarth! Penarth! Cogan Pill, I899! Porthkerry! U.C. Hb. Ed.

1825. Sciuroides, Roth. Barren Fescue-grass. Peisg-wellt anhiliawg. Local. Frequent. Native. Glareal.

More abundant than the last species. Briton Ferry. Lightfoot. $J$. of B. 1905. p. 299. Sandhills, etc, about Swansea. Gutch. Phyt. 1842. p. I82. Frequent about Cardiff. J.S. Kenfig ! Southerndown Road ! Taffs Well ! Cold Knap ! Hayes ! Sully ! Dinas Powys! Ed.

1 826. ovina, Linn. Sheep's Fescue-grass. Peisg-wellt y defaid.

Common. Abundant. Native. Pascual.

From the farmer's point of view, rather scarce. The upland pastures are therefore of poor quality, and consequently shrubby plants like the heather and bilberry are cropped close by the sheep. Ed. The viviparous form occurs on Cefn Bryn. Gutch. Phyt. I842. p. I82. The varieties tenuifolia and major, Syme, occur in the county. Ed.

1827. rubra, Linn.

Common. Abundant. Native. Littoral, etc.

The varieties or "elementary species " of the two preceding species are, I believe, numerous; and as both types are of considerable economic importance, should be thoroughly investigated. The two species are readily separable by their mode of growth, but the varieties are not easily defined and classified. It is not improbable that the same variety has several different forms adapted to different habitats. F. rubra and its forms occur in pastures, meadows, and on arable lands; on the estuary muds, on coast rocks and cliffs, and on maritime sands. The forms arenaria and prinosa occur all round the coast.

1830. sylvatica, Vill. Wood Fescue-grass.

Rare. Scarce. Native. Sylvestral.

Ystalyfera. Ridd. 
1831. elatior, Linn. Tall Fescue-grass. Peisg-wyllt hydwf.

Common. Abundant. Native. Pratal. county.

Even, as an aggregate, however, a rather scarce grass in this

b. pseudo-loliacea, Hackel. Aberdare. Ridd. J. of B. I906. p. 7o. Pont Nedd Fechan; Killay; several places in the Swansea district. Dillwyn. Gutch. Phyt. 1842. p. I82. Near Mill Race, Llandaff. J.S. Cardiff. Ridd.

c. pratensis, Huds. Aberdare. Ridd. $J$. of $B$. I906. p. 70. Meadows, everywhere. J.S. Graigafan; Llandough. Ridd. Peterston ! Penarth! and many other places, I think, of which no definite record has been made. $E d$.

\section{2. arundinacea, Schreb.}

Local. Frequent. Native. Littoral.

Park Mill; Llangenydd; Port Eynon; Port Talbot; Nash Point; Aberthaw; Cadoxton; Swanbridge ; Cardiff ; Aberdare ; Pengam Marshes. Ridd. Cliffs and tips at Penarth $!$ Barry Island, I 899 ! Cold Knap ! Porthkerry ! Flourishes on the clayey debris which collects below the Lias cliffs, forming in such places very large, isolated, coarse tufts. $E d$.

\section{Bromus, Linn. 506.}

1833. giganteus, Linn. Tall Brome-grass. Peisg-wellt hirian.

Local. Abundant. Native. Septal, sylvestral.

Swansea, common. Gutch. Phyt. I842. p. I82. Leckwith; near Dinas Powys Castle. J.S. Penrice ; Horton. Miss S. Neddfechan Glen; Baglan; Laleston ; Llandow ; Marcross ; Cowbridge ; Barry; Cadoxton to Wenvoe; Aberdare; Welsh St. Donat's; Rudry. Ridd. Cwrtyrala ! Llandough ! Cogan Pill ! Llanharry! Peterston ! Ed.

1834. ramosus, Huds. (= asper, Murr.) Rough Brome-grass.

Pawr-wellt blewog.

Local. Abundant. Native. Septal, sylvestral.

Records from the lowlands too numerous for citation. Neddfechan Glen; Aberdare. Ridd. Merthyr district. E. and F.

I 835. erectus, Huds. Upright perennial Brome-grass. Pawr-wellt uniawnsyth.

Local. Frequent. Native. Pascual, etc.

Port Talbot; Porthcawl; S. Cornelau ; Ewenny ; St. Bride's Major; Cadoxton; Swanbridge; Porthkerry; Llantwit Major; Nash Point; Aberdare; Welsh St. Donat's. Ridd. Very abundant near the coast from Aberthaw to Porthkerry! I9Io. Ed.

1836. madritensis, Linn. Upright annual Brome-grass.

Rare. Frequent. Native or Denizen. Glareal.

Swansea. Gutch. Phyt. I842. p. I 82. Port Talbot and Cardiff, as an alien. Ridd. Penarth ! ! on the red marls, where it has flourished for years; indistinguishable from a native. It is often accompanied by $B$. sterilis, and an intermediate type which will probably prove to be the hybrid madritensis $\times$ steritis. Ed. 
1839. sterilis, Linn. Barren Brome-grass. Pawr-wellt anhiliawg.

Common. Abundant. Native. Viatical, glareal, etc.

1840. secalinus, Linn. Rye Brome-grass. Pawr-wellt Ller.

Rare. Scarce. Colonist. Agrestal.

Near Pennard Castle. J. Ball. Bot. Gaz. Vol. I. p. Iog. Cardiff; near Aubrey Arms, Bonvilstone. J.S. Aberdare. Nat. Hb., Ridd. Port Talbot, Ridd.

1841. racemosus, Linn. Racemose Brome-grass. Pawr-wellt llyfn.

Rare. Scarce. Native? Pratal.

Caerau. Ridd.

1842. commutatus, Schrad. Confused Brome-grass.

Local. Frequent. Native. Pratal, etc.

About Cardiff, Penarth, and Barry. J.S Oxwich ; Penclawdd ; Port Talbot ; Ewenny Bridge ; Llantwit Major ; Aberdare ; Merthyr Tydfil; Pengam Marshes. Ridd.

1 843. mollis, Linn. Soft Brome-grass. Pawr-wellt maswg.

Common. Abundant. Native. Pratal, etc.

Even as a segregate this form is widespread. Numerous varieties have been described, but I am so unfamiliar with the various Serrafalcus forms that I am quite unable to estimate their value. Mr. Riddelsdell records habitats for glabratus Doell, leptostachys Pers, Thominii (Hard.), Lloydianus Gren. E God., and hordeaceus Fr.

\section{Brachypodium, Beauv. 507.}

1845. gracile, Beauv. (= sylvaticum, Roem \& Schult.) False Wood Brome-grass.

Common. Abundant. Native. Sylvestral, \&c.

Does this plant occur on the coal measures? All records appear to be for the calcareous areas only.

1846. pinnatum, Beauv. Barren False Brome-grass.

Rare. Abundant. Native. Pascual.

Cold Knap! Ridd. and very abundant at other points in the neighbourhood! Ed.

\section{Lolium, Linn. 508.}

1847. perenne, Linn. Perennial Rye-grass. Efryn parhaus.

Common. Abundant. Native. Pratal, pascual, etc. Several varieties occur.

\section{Agropyron, J. Gært. 509.}

I 850. caninum, Beauv. Wood Couch-grass. Gwenith-wellt sypwraidd coliog.

Local. Frequent. Native. Sylvestral, etc.

Cooper's Fields; Llandaff; near Cog; Kymin. J.S. Gowerton; Pantyffynon; Ystalyfera; Resolven; Neddfechan and Perddyn Glens! Aberdare, Ridd. Llanharran! U.C. Hb. Ed. 
1851. repens, Beauv. Common Couch-grass. Gwenith-wellt ymdanawl. Common. Abundant. Native. Agrestal, etc.

var. barbatum, Duval-Jouve. Oxwich; Langland Bay; Glyn Neath ; Port Talbot; Porthcawl; S. Cornely; Llandaff ; Cardiff ; Ridd. Taffs Well ! Cwm Alun! Swanbridge! Ed.

1852. pungens, Roem \& Schult. Erect Sea Couch-grass.

Rare. Frequent. Native. Littoral.

Porthcawl. Nat. Hb. Ridd. Ely and Taff estuaries! Ed.

1854. junceum, Beauv. Sand Couch-grass. Gwenith-wellt brwynaidd y morlan.

Local. Frequent, Native, Littoral.

Occurs all along the coast in suitable localities from Penarth to Whitford, and is commonest in the west, being very fine and abundant at Port Eynon. Ed.

$\times$ repens. Port Talbot; Porthcawl. Ridd.

\section{Lepturus, R.Br. 5 Io.}

1855. filiformis, Trin. Sea Hard-grass. Corwelltyn camaind, Corwellt y morfa.

Local. Frequent. Native. Littoral.

Port Tennant. Gutch. Phyt. I842. p. I8I. Cardiff, Penarth, Sully, Barry ! J.S. Ely Estuary ! V. Gowerton ; Loughor ; Neath ; Port Talbot; Margam Marshes ; St. Athan's Road ; Porthkerry; Pengam Marshes. Ridd. Barry Salt Marsh! Leys!. Ed.

\section{Nardus, Linn. 5 II.}

I 856. stricta, Linn. Mat-grass. Cawnen ddû, Câs gan bladwrwr.

Common. Abundant. Native. Ericetal.

\section{Hordeum, Linn. 512 .}

1858. secalinum, Schreb. (=pratense, Huds.) Meadow Barley.

Common. Abundant. Native. Pratal, etc.

In one field near Penarth it is, perhaps, the chief grass. $E d$.

1859. murinum, Linn. Wall Barley. Haidd-wellt y muriau.

Local. Frequent. Native. Glareal, viatical, etc.

Very common at many points along the coast. No records from inland stations.

1860. marinum, Huds. Sea Barley.

Rare. Scarce. Native. Littoral.

Not infrequent about Swansea. L.W.D., B.G. The Leys. Ridd. Near Bute Docks, Cardiff ! I89I ; Ely Estuary ! Storrie's record is clearly erroneous. Ed. 


\section{Elymus, Linn. 513.}

186 I. arenarius, Linn. Sand Lyme-grass. Amdo-wellt.

Rare. Scarce. Colonist? Littoral.

Swansea; (Moggridge), Port Talbot. Ridd. Porthkerry. J.S. The status of this plant is marked doubtful, as all these localities are places where aliens might be expected. I have searched in vain for the plant and have never seen it anywhere in Wales. Moreover, it is a grass that is not likely to escape notice. Probably a casual. Ed.

\section{Filices.}

\section{Hymenophyllum, Sm. 514.}

1862. tunbridgense, Sm. Tunbridge Filmy Fern. Rhedynach teneuwe. Rare. Scarce. Native. Rupestral.

Pont Nedd Vechan. L.W.D., B.G. Bryncous, above Cadoxton Village. L.W.D. Mat. Melincourt waterfall. Westcombe and Young. Newman's Hist. Brit. Ferns. p. 299. Pencaedrain! growing with $H$. unilaterale, 1892 to 1905 . U.C. $H b$. This locality was recently wiped out by quarrying operations. $E d$. Dimbath Valley, near Black Mill. Miss B. Near Abertridwr. J.S.(2). The last record may be for 1863 , as it is fairly evident that Storrie never learned to distinguish the two segregates.

1863. unilaterale, Bory. Wilson's Filmy Fern.

Local. Plentiful. Native. Rupestral.

Melincourt Glen and Perddyn Glen. E. Young. Newman's Hist. Brit. Ferms. p. 299. Cwm-cidy. J. J. Neale and T. W. Proger. Dimbath Valley, near Black Mill, rare. Miss $B$. Rhondda Valley; near Pentre ; above Blaenrhondda! and near Llyn Vach! J.S. All recorded under $H$. tunbridgense, but doubtless referring to this species. Ed. Daren Bwllfa; Cwm Selsig. Ridd. Craig-y-llyn! from I 892 onwards, abundant; Pencaedrain! Graig fawr and Graig fach, Cwmparc ! Craig-y-bwlch ! and other places on the Pennant Grit escarpments. Ed. Dr. Alfred Russell Wallace told me in Igog that the Hymenphyllum formed great masses, clothing the rocks in the Upper Neath Valley when he was surveying for the Neath and Merthyr Rail. Co. in 1842 . T.H.T.

\section{Adiantum, Linn. 516.}

1865. Capillus-Veneris, Linn. Maidenhair. Briger Gwener, Briger Gweno.

Local. Frequent. Native. Rupestral.

Nine-acre cliff-half-a-mile from Porthkerry Church; Nash Point! Lightfoot. J. of B. 1905. p. 299 and 300. "Growing very plentifully out of a marly incrustation both at Barry Island and Porth Kirig . . . . a and out of no other matter." Letter of Ed. Llwyd. Nov. 24th, I696. Phyt. I855-56. p. 268. Phil.Trans. Vol. VI. I 7 I 3. $p .20$. Common on Lias cliffs at the eastern end of the county ; 
not nearer to Swansea than Dunraven! Gutch. Phyt. 1842. p. I83. Fontigary! very abundant! and sparingly as far as Dunraven! J.S. By the wall on the Rhiw leading to the Kymin, Penarth. I6.5.I847. J.E. The species originally ranged from Penarth to Dunraven, and as it is often quite inaccessible it is not in danger of extermination. Plants still grew at Barry in 1899 and at Dunraven in 1907. It is strictly confined to the coast, and almost, though not quite, to the peculiar habitat noticed by Llwyd over 200 years ago-wet rocks, incrusted with a calcareous deposit, and provided with deep wellsheltered pockets. It occurs, however, on the clays and shales between the limestones in the immediate neighbourhood of such spots, but only when protected by tufts of grass or other vegetation. The critical factor governing its distribution appears to be that of temperature-the water supply is probably of secondary importance. Frost is rare on the coast, but nevertheless the winter cold regularly destroys the leaves. The rhizomes are protected from extreme cold by the water (weak springs), and in exceptional seasons, perhaps by a covering of ice. Measurements of the temperature of this water and of the solid substratum, observations on the freezing of the water and laboratory experiments on the effects of low temperatures on this species would be of great value, and give much-needed information as to the critical factors which limit the distribution of such a species.

\section{Pteris, Linn. 517.}

I 866. aquilina, Linn. Bracken. Adain-redynen eryraidd.

Common. Abundant. Native. Ericetal, sylvestral, etc.

It is worthy of note that the bracken with us occurs in great abundance on the fixed sand dunes, being often the dominant species. Massart, in his studies of the Belgian flora, describes it as calcifuge, absent from the dunes, or rare there. The difference in rainfall or atmospheric humidity probably accounts for its different behaviour in these two areas. As this fern is a cosmopolitan plant-perhaps the most widely distributed of all ferns-it must possess great powers of adaptation.

\section{Cryptogramme, R.Br. 5 I8.}

1867. crispa, R.Br. Parsley Fern. Adain-redynen y chwarelau.

Local. Scarce. Native. Rupestral.

Mountain above Aberdare; rare. J.S. Ferndale, very rare.

Fl. Rhondda. Padell-y Bwlch; Daren Bwllfa. Ridd. Mardy. Mr. Walker. Aberdare. Ed. Young. Ferns of Wales. Mynydd Mayo, near Abertridwr. J.S. (2), T.H.T. and V. Graig fawr, Cwm Parc. ! I4-8-98. Craig-y-llyn! 1905. U.C. Hb. Always, I believe, on the screes of the Pennant Grit. Ed.

\section{Lomaria, Willd. 519.}

1868. Spicant, Desv. Hard Fern. Rhedyn Gwîb. Common. Abundant. Native. Ericetal, sylvestral, etc. 


\section{Asplenium, Linn. $\mathbf{5 2 0 .}$}

1870. Ianceolatum, Huds. Lanceolate Spleenwort.

Rare. Scarce. Native. Rupestral.

Town Hill, near Swansea. Gutch. Phyt. I842. p. I83. Penmaen. E. F. Linton. Ridd. Pontypridd Common! U.C. Hb., I89r. Now extinct, I believe. Ed.

1871. Adiantum=nigrum, Linn. Black Spleenwort. Dueg-redynen ddû, Dugoesog, Duwallt y forwyn.

Local. Abundant. Native. Rupestral, etc.

Very numerous records from all parts of the county, though not exactly a common plant.

1872. marinum, Linn. Sea Spleenwort. Dueg-redynen arfor.

Local. Frequent. Native. Littoral, rupestral.

Nash Point; Briton Ferry. Lightfoot. J. of B. 1905. pp. 299, 300. Along the coast of Gower ! common. Plentiful in Bacon's Hole ! Gutch. Phyt. 1842. p. I83. Barry! Dunraven ! J.S. Barry Island! Flat Holme ! J.S. (2). Mumbles, 1877. U.C. Hb., Prof. C. M. Thompson. Gower coast, general. Miss S. Southerndown. M.A.D., I., and $V$. Near Margam Abbey-three miles from the sea. E. Young. Ferns of Wales. St. Donats. G.T. Neath. Newman. Hist. Brit. Ferns. p. 238. Temple Bay, Dunraven. Miss B. Burry Holmes! 1908. U.C. Hb. Thinly scattered along the coast, being most abundant in the west. $E d$.

1873. viride, Huds, Green Spleenwort.

Rare. Scarce. Native. Rupestral.

Merthyr district. E. and $F$. Morlais Castle I U.C. Hb., I 89o.

Ed. Near Pont Nedd Vechan (possibly in Brecon). Gutch. Phyt. 1842. p. 183. There is thus only one certain habitat for this plant in Glamorgan. $E d$.

1874. Trichomanes, Linn. Maidenhair Spleenwort. Dueg-redynen. Gwallt y forwyn.

Common. Abundant. Native. Rupestral.

1875. Ruta-muraria, Linn. Wall Rue. Dueg-redynen y muriau, Rhyw'r muriau.

Common. Abundant. Native. Rupestral.

\section{Athyrium, Roth. 52I.}

1878. Filix-fœmina, Roth. Lady Fern. March-redynen fenyw.

Common. Abundant. Native. Sylvestral, etc.

b. erectum, Syme. Frequent in the county. T.H.T. Fairwood Common; Crumlin Bog: Mountain Ash; Hirwaun. Ridd.

c, incisum, Roth. Aberpergwm. Ridd. 


\section{Ceterach, Willd. 522 .}

1881. officinarum, Willd. Common Scale-fern. Rherlyn y gogofau, Dueg-redynen feddygawl.

Common. Abundant. Native. Rupestral.

Confined to calcareous habitats. Apparently rare, on the walls, on the coal measures.

b. crenatum, Milde. Glyn Neath; Aberdare. Ridd.

\section{Scolopendrium, Adans. $\mathbf{5 2 3}$.}

1882. vulgare, Symons. Hart's-tongue Fern. Tafod yr hûdd cyffredin. Common. Abundant. Native. Septal, sylvestral, rupestral, etc.

This fern is extremely common in the calcareous areas, especially on the Lias. Rare on the coal measures, and confined there to walls and similar calcareous habitats. Rather uniform in type for such a variable species. $E d$.

\section{Cystopteris, Bernh. $\mathbf{5 2 5}$.}

1885. fragilis, Bernh. Brittle Bladder-fern. Ffiol-redynen ddeintiawg. Local. Frequent. Native. Rupestral.

Kilvey Hill. Gutch. Phyt. I842. p. 182. Heads of Swansea and Neath Valleys. L.W.D. Mat. These may be Brecknock localities. $E d$. Rhondda Valley, near Ystradyfodwg, very rare. J.S. Blaenrhondda! Abercanaid; near Merthyr. J.S. (2). Rhondda Fach ; Neath Valley; Swansea Valley. T.H.T. Merthyr district. E. and F. Aberdare, Dowlais. Ridd. Morlais Castle and neighbourhood ! Always, I believe, of the dentata form. Ed. Fine specimens at Castellan, near Llantrissant. 2I-4-1897. Cwm Ffrwd, Merthyr. 1904. T.H.T.

Polystichum, Roth. 526.

1888. Lonchitis, Roth. Alpine Holly Fern.

All the records for this species doubtless refer to specimens of I 889.

1889. Lobatum, Pres1. Hard Prickly Shieldfern. March-redynen glustiawg.

Local. Frequent. Native. Rupestral, sylvestral.

Numerous records from all parts of the county except the valleys of the Loughor and Rhymney. Ed.

1890. angulare, Presl. Soft Prickly Shieldfern. March-redynen wrychog. Common. Abundant. Native. Sylvestral, etc.

No record from the valley of the Loughor. Commoner than the preceding species in the lowlands, perhaps rarer in the uplands. Ed. 


\section{Lastræa, Presl. 527.}

1891. Thelypteris, Presl. Marsh Fern. March-redynen y gors.

Rare. Scarce. Native. Uliginal.

Sketty Bog. E. Forster, junior, B.G. Cwmbwrla and marshy ground in the neighbourhood of Swansea. Gutch. Phyt. I842. p. I82. Sketty Bog. G.T. "I have seen Gutch's specimenscertainly Thelypteris." J.S. (2). Singleton Bog. Ed. Young. Ferns of Wales. Llynfach. Ridd.

1892. Oreopteris, Presl. Mountain Fern. March-redynen y mynydd, Rhedyn Mair.

Common. Abundant. Native. Ericetal, etc.

No record for the Ddaw Valley. Very rare in the lowlands. Between Swansea and Park Mill. E. Forster, B.G. Pendoylan. I. Draethan! Ed.

1893. Filix-mas, Presl. Male Fern. March-redynen wrryw, Rhedyn y Cadno.

Common. Abundant. Native. Sylvestral, rupestral.

Several types occur in the county, and need further investigation. Ed.

1898. spinulosa, Presl. Narrow Shield-fern. March-redynen eddiawg.

Rare. Scarce. Native. Sylvestral ?

Maesteg. Mr. Bicheno. L.W.D. Mat. Ystradowen. V. Vach. Herb.! Crumlin Bog; Radyr. Ridd.

1899. dilatata, Presl. Broad Shield-fern. March-redynen eang.

Common. Abundant. Native. Sylvestral, rupestral.

Very variable; the form which grows on the screes of the uplands, and which differs much from the woodland type of the lowlands, has been frequently mistaken for $L$. cemula.

1900. æmula, Brackenridge. Hay-scented Fern.

Rare. Scarce. Native. Sylvestral, rupestral.

Melincourt Waterfall. Ed. Young. Ferns of Wales. Possibly now extinct. All other records are almost certainly based on specimens of $1899 . E d$.

\section{Polypodium, Linn. 528.}

1901. vulgare, Linn. Common Polypody. Llawredynen y derw, Llawredynen y fagwyr.

Common. Abundant. Native. Rupestral, sylvestral, \&c.

b. serratum, Willd. Leckwith Wood. I899. Vach. Herb.! V. Cwm George! T.H.T., Ridd., and Ed.

c. cambricum, Willd. "On a rock in a wood near Dennys Powis Castle, not far from Cardiff" Ray. Syn. I689. p. 22. Was completely destroyed by a fern dealer about 1876 , who sold hundreds of specimens at one shilling each. J.S. Storrie showed me the habitat which had been occupied by these plants, and I have little doubt 
that it was not the one discovered by Ray. This sterile form and the intermediate type serratum are probably the offspring of the type. All three forms may occur in the same locality. ()ther varieties have been recognised and named but do not merit inclusion. Ed.

\section{Phegopteris, Presl. 529.}

1902. Dryopteris, Fée. Oak Fern.

Local. Frequent. Native. Sylvestral, rupestral.

Rocks about Pont Nedd Vechan. L.W.D. B.G. Perddyn Valley! I879. U.C. Hb. Prot. C. M. Thompson. Very abundant about I 895 ; now very rare but recorded by $M \cdot A . D$. "I have not seen" this species at St. Hilary and Cwmffrwdor. J.S. (2). Vale of Neath. $H$; Pontardulais ; Aberdare; Padell-y-Bwlch ; Graigfach, Cwmparc. Ridd. Cwm Wyrfa. W. Pont Henrhyd. E. Lees, Bot. Looker-out. p. 208. Near Draethen. Mr. Birkenhead. Craig-yllyn, on the screes! Ed.

1903. calcarea, Fée. Limestone Polypody.

Rare. Abundant. Native. Rupestral.

Hirwaun Common. W. Morlais Castle ! U.C. Hb. 1890. E. and F., and T.H.T. Old Castle Down, abundant ! Ed. Near Draethen. $M r$. Wright.

1904. polypodioides, Fée. Beech Fern.

Local. Abundant. Native. Rupestral, sylvestral.

Uscoed Eynon Gam, and the Ladies Fall, near Pont Nedd Vechan! E. Forster, jinior, B.G. So common on the escarpments of the Pennant Grit ! at the heads of the chief valleys, that the separate records cannot be cited. Ed. Penllergare, L.WW.D. Mat. Navigation. J.S. (2). Neath Valley. G.T. Merthyr district. E. and F. Draethen! Willowford! Quaker's Yard! and some other lowland localities for which there is no definite record. Ed.

\section{Osmunda, Linn. 531 .}

1906. regalis, Linn. Royal Fern. Lloer-redynen cyfrdwy, Rhedynen cyfrdwy, Rhedyn Crist (in Glamorgan).

Local. Frequent. Native. Paludal, etc.

Crymlin Bog ! Lightfoot. J. of B. 1905. p. 299. Near Cwmbwrla and other places about Swansea. Gutch. Phyt. 1842. p. 183. Frequent in the county. L.W.D., B.G. Penllergare. Trans. Swansea Sci. Soc. I895-6. p. 77. Black Mill; Wain-y-Llan ; Wain-y-Gilfach, near Llangonoyd ! J.S. Glyncorwg ! J.S. (2). Neath. Miss Ollivant. Maesteg; Tondû; Vale of Neath. $H$. Dimbath Valley. Miss B. Penrice. Miss S. Rhossili. Miss S. and M.A.D. Pendoylan, i884. I. Llangenydd, Gower. T.H.T. Ystradowen; Aberdare; Mountain Ash. Ridd. Cwmtwrch, Glamorganshire, very abundant in 1890 . U.C. Hb., Ed. 


\section{Ophioglossum, Linn. 532.}

1907. vulgatum, Linn. Common Adder's-tongue. Tafod y neidr cyffredin.

Common. Abundant. Native. Pascual, etc.

Very widespread and abundant on the pastures of the Vale of Glamorgan, but easily overlooked. In S.W. Glamorgan it occurs very often associated with the cowslips and Orchis Morio. The records for other areas, where the plant is apparently less abundant, are given. Ed. Merthyr district. E. and $F$. Glyn Clydach and Penygraig, near Neath. E. Young. Ferns of Wales. Taffs Well. T.H.T. Southerndown. V. Penllergare. Trans. Swansea Sci. Soc. 1895-6. p. 77. Frequent in Gower; Glyn Neath; Aberafan marshes; Kenfig; Porthcawl. Ridd. Cefn On, abundant, I908 ! Pencaedrain! Ed.

b. polyphyllum, Braun. Whitford Burrows. E.F.L., Ridd.

\section{Botrychium, Sw. 533 .}

1909. Lunaria, Sw. Moonwort. Lloer-redynen gyffredin.

Local. Scarce. Native. Pascual, ericetal.

Penrice Castle; Nicholaston Wood and other woods in the neighbourhood. (Dillwyn). Gutch. Phyt. 1842. p. 183. Drymma. Edward Hawkins, L.W.D. Mat. Coedriglan; Llantrithyd; Coychurch; and sandhills at Newton Nottage. J.S. . Near Castle Coch. J.S. (2) and Mr. Chapman. Clydach Vale. Fl. Rhondda and $W$. Merthyr district. E. and $F$. Sandhills near Newton Nottage; Talygarn. V. Cowbridge; Llanbleddian; Garth Wood; Abercynon; Aberaman. Ridd. Neath neighbourhood. E. Young. Ferns of Wales. Ystradowen! Ed.

\section{Equisetaceæ.}

\section{Equisetum, Linn. 534.}

I9ro. maximum, Lam. Great Horse-tail. Rhawn y march afonawl.

Local. Abundant. Native. Paludal, sylvestral, etc.

Cromlyn Bog and other bogs in the neighbourhood. Recorded under E. fluviatile. Gutch. Phyt. 1842. p. 183. Wood near Leckwith Bridge! J.S. Bodringallt; Aberllechau. Fl. Rhondda. Cwrtyrala. H. Merthyr district. E. and F. Mumbles Road; Sketty Burrows ; Porthkerry ; Merthyr Dyfan ; Llanishen ; Lisvane. Ridd. Perddyn Glen! Cefn On ! very abundant about Cogan ! Grangetown! and in other places. Ed.

191 I. arvense, Linn. Common Horsetail. Rhawn y march yr ârdir. Common. Abundant. Native. Agrestal, viatical, inundatal, etc. 
1913. sylvaticum, Linn. Wood Horsetail.

Local. Abundant. Native. Sylvestral, etc.

About Bryn Morgan Colliery, and other places in the Vale of Tawe (L.W.D.); near Quaker's Yard (E. Forster, junior.) B.G. Near Cwmbwrla; Drymma Wood, between Neath and Swansea. Gutch. Phyt. 1842. p. I83. Common in Swansea and Neath Valleys. L.W.D. Mat. Common in woods. Leckwith; St. Fagans, etc. J.S. Wrinstone. $H$. Hendrescythan Wood, near Pentyrch. Miss $B$. Merthyr district. $E$. and $F$. Reynoldstone. Miss $S$. Leckwith, 183r. J.E. Pendoylan. $I$. and $V$. Penllergaer to Gowerton; Maesteg; Ridd. Caerphilly ! Ed.

b. capillare, (Hoffm.). Cefn On! Ridd. and Ed.

1914 . palustre, Linn. Marsh Horsetail. Rhawn y march y gors.

Common. Abundant. Native. Paludal.

The three recognised forms occur in the county.

1916. limosum, Sm. Water Horsetail. Rhawn y march lled-diddail.

Common. Abundant. Native. Paludal.

The two recognised forms occur in the county.

1917. hyemale, Linn. Rough Horsetail.

Rare. Scarce. Native. Paludal.

Penllergare and Cromlyn Bog, where Mr. Moggridge states it to be abundant. Gutch. Phyt. I842. p. I83. Rare in damp woods; near Tongwynlais and Melingriffith. J.S. No recent records.

1920. variegatum, Schleich; a. arenarium, Newman. Variegated Horsetail.

Rare. Abundant. Native. Inundatal, paludal.

Sandy shallow ditch beside a railway near Swansea. 26-4-86. Bot. Exch. Club Report. 1886. p. 163. W. R. Linton. "In enormous quantity, filling the ditches on both sides of the railway, Crymlyn Burrows; growing luxuriantly and fruiting very freely." W. R. Linton. J. of B. I886. p. 377. Where Crumlyn Bog borders Crumlyn Burrows, 1905. Nat.Hb., Ridd.

\section{Lycopodiaceæ.}

\section{Lycopodium, Linn. 535 .}

1921. Selago, Linn. Fir Clubmoss. Cnwp-fwsogl syth mwyaf.

Rare. Scarce, Native. Rupestral.

Swansea Valley. L.W.D. Mat. A few plants about waterfall below Carn Mosyn; June, i89i. T.H.T. Cwm Parc, Treorchy! W. Proger and J.J. Neale. Craig-y-llyn ! Craig-y-Bwlch ! All the plants seen by me grew on the rocks and were of the recurvum form, and thus very unlike the short, tufted, erect form so common in N. Wales. $E d$. 
1924. clavatum, Linn. Common Clubmoss.

The records for this species are all doubtful, but are inserted that further search may be made, as it is quite likely to occur in the county. Ed. Head of Swansea Valley. L.W.D. Mat. This may be a Brecknock locality. Ed. "Near Pencoed, Caerphilly?" J.S. (2). This note probably refers to information received, rather than to observations made by Storrie.

The still more doubtful records for $L$. alpinum are excluded, though there is no positive reason why the species should not occur about Craig-y-llyn and Cwm Parc. It is recorded from Dunkerry Beacon, Somerset, at I,668 feet above sea level.

\section{Selaginellaceæ.}

Selaginella, Spring. 536 .

1926. selaginoides, Gray. Lesser Alpine Clubmoss. Cnwp-fwsogl syth lleiaf.

Rare. Scarce. Native. Uliginal, rupestral.

One doubtful record :-Mountains near Glyn Corrwg and Carnfach. J.S. The only reason for doubting this record is the fact that Mr. Storrie appears occasionally to have transposed the names of species having similar sounds or origins. This species does not otherwise occur south of Merioneth. It is not improbable that the species found by Storrie was $L$. Selago.

\section{Isoetes, Linn. 537 .}

1927. lacustris, Linn. Lake Quillwort. Gwair merllyn.

Rare. Abundant. Native. Lacustral.

Llynfach! Mr. Moggridge, L.W.D. Mat. Llyn fawr! 1892 and 1899. U.C. Hb., Ed.

\section{8. echinospora, Dur.}

Llyn fawr ! ! I899. Ed. Both species occur together in Llyn fawr. Plants were brought up from a depth of about 6 feet by Mr. J. J. Neale from a point where they covered the muddy substratum as a pure formation. They were all preserved in alcohol and have been used regularly since for demonstration purposes. Both types of spore occur in this material, and always on different plants. I. echinospora may be the deep water form or species, a fact which would account for its supposed greater rarity. The leaves are certainly longer in this type. Moreover, both the Glamorgan forms differ markedly from Carnarvonshire specimens. Are there three types in Britain? This species has been recorded hitherto only from Carnarvon, and eight Scotch districts, all N. of the Clyde. 


\section{Marsileaceæ.}

\section{Pilularia, Linn. 538 .}

1930. globulifera, Linn. Pillwort. Pelanllys gronynawg.

Rare. Abundant. Native. Lacustral, uliginal, etc.

Pen Craig y Llyn Vach, a mountain pool near Pont Nedd V'echan. J. Woods, junior, B.G. Llynfach. J.S. Now extinct. Ed. Welsh

St. Donat's ! 1905 to I9I0, very abundant. Ed. and Ridd.

This Section completes Vol. I. of the Flora of Glamorgan.

It is proposed to issue a second volume, in which the geographical distribution, œcology, and "critical" species and varieties will receive fuller treatment than was possible in Vol. I.

Correspondents are requested to send notes of interest for Volume II., as well as additions to, or corrections of Vol. I. to the Hon. Secs., Dr. C. T. Vachell and Miss E. Vachell. Ed. 


\section{INDEX}

\section{OF THE POPULAR ENGLish NAMES,}

Prepared by Mr. H. M. HalletT, Hon. Sec. of the

Biological Section of the Society.

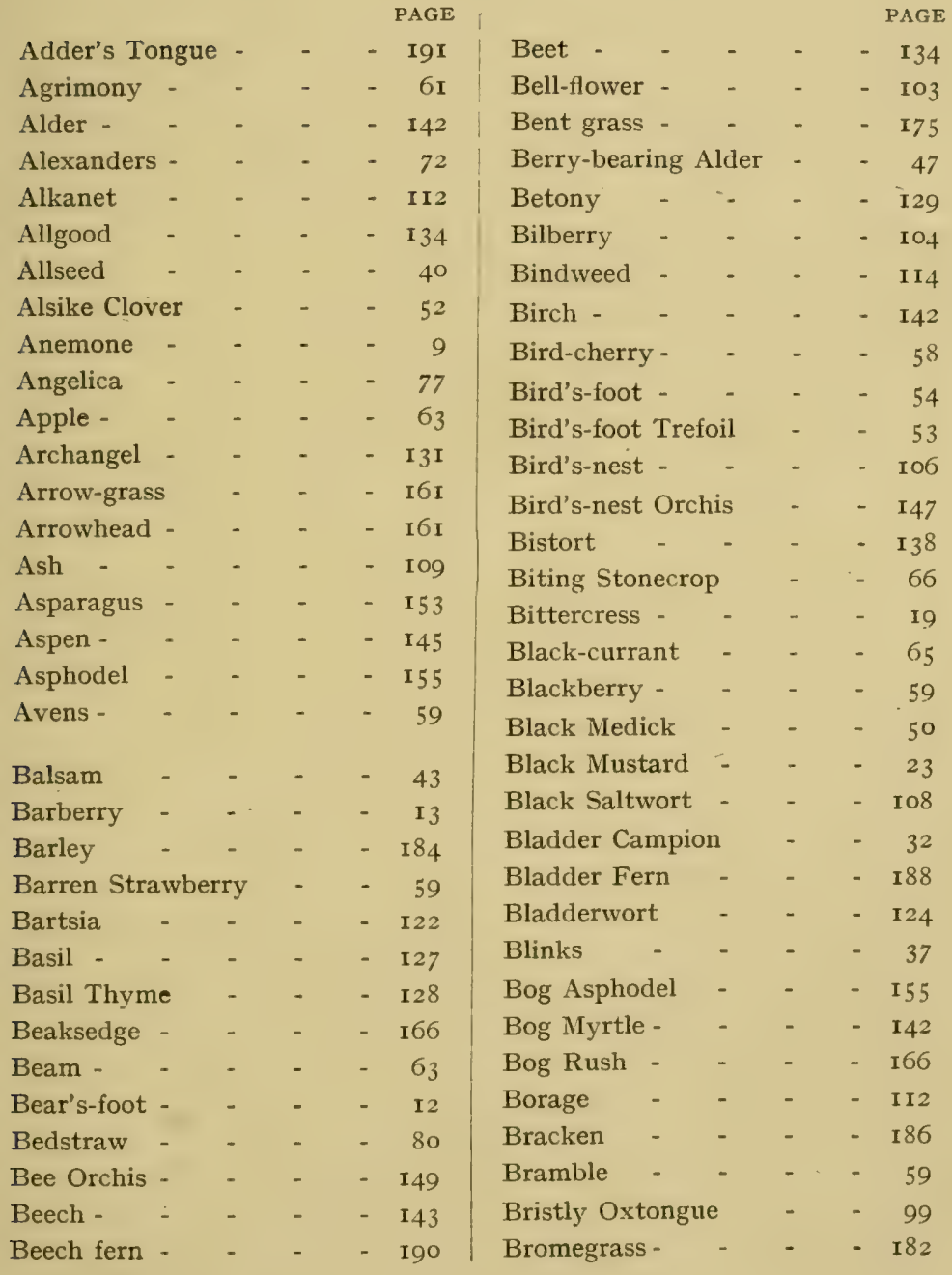




\begin{tabular}{|c|c|c|c|c|c|c|c|c|c|}
\hline & & & & PAGE & & & & & PAGE \\
\hline Brooklime & - & - & - & $-\quad I 2 I$ & Chaffweed & - & - & & - 108 \\
\hline Brookweed & $1-$ & - & - & - 108 & Chamomile & - & - & - & 88,89 \\
\hline Broom & - & - & - & $\begin{array}{l}-49 \\
\end{array}$ & Charlock & - & - & - & 23 \\
\hline Broomrape & - & - & - & $-\quad 123$ & Cherry & - & - & - & 57 \\
\hline Bryony, $\mathrm{Bl}$ & lack & - & - & $-\quad 5_{52}$ & Chervil & - & - & - & 75 \\
\hline Bryony, Re & ed $\mathrm{Be}$ & rried & - & -71 & Chickweed & - & - & - & 33 \\
\hline Buckbean & - & - & - & $-\quad I I I$ & Cicely, Swe & & - & - & 75 \\
\hline Buck's-horn & n Pla & ntain & - & $-\quad 132$ & Cinquefoil & - & - & - & 60 \\
\hline Buckthorn & - & - & - & 47 & Clary - & - & - & - & 128 \\
\hline Buckwheat & $t-$ & - & - & I36 & Clover & - & - & - & 5 I \\
\hline Bugle - & - & - & - & I 32 & Club-moss & - & - & - & I92 \\
\hline Bugloss & - & - & - & $-\quad$ II 2 & Club-rush & - & - & - & I64 \\
\hline Bugloss, Vi & iper's & - & - & $-\quad$ II4 & Cock's-foot & Gra & & - & $-\quad 178$ \\
\hline Bullace & - & - & - & 57 & Coltsfoot & - & - & - & 90 \\
\hline Bulrush & - & - & - & I65 & Columbine & - & - & - & $\mathrm{I} 2$ \\
\hline Burdock & - & - & - & 94 & Comfrey & - & - & - & I I I \\
\hline Burnet & - & - & - & $6 \mathbf{I}$ & Corn Cockle & & - & - & 33 \\
\hline Burnet Ros & & - & - & $6 \mathrm{I}$ & Cornflower & - & - & - & 98 \\
\hline Burnet Sax & xifrage & & - & 74 & Corn Marig & old & - & - & 89 \\
\hline Bur-Marygc & old & - & - & 88 & Cotton Gras & & - & - & I66 \\
\hline Bur Medick & & - & - & 50 & Couch Gras & & - & - & $-\quad I 83$ \\
\hline Bur-reed & - & - & - & $-\quad I_{58}$ & Cow Parsni & & - & - & $\begin{array}{l}-\quad 77 \\
\end{array}$ \\
\hline Butcher's B & Broom & & - & $-\quad \mathrm{I} 52$ & Cowslip & - & - & - & - 107 \\
\hline Butterbur & - & - & - & 90 & Cow-wheat & - & - & - & I23 \\
\hline Buttercup & - & - & - & IO & Crab Apple & - & - & - & 63 \\
\hline Butterfly O & Orchis & - & - & $-\quad 150$ & Cranberry & - & - & - & 104 \\
\hline Butterwort & & - & - & $\mathbf{1 2 5}$ & Cranesbill & - & - & - & $4 I$ \\
\hline & & & & & Crested Hai & ir $\mathrm{Gr}$ & ass & - & $-\quad I 78$ \\
\hline Cabbage & - & - & - & 22 & Crosswort & - & $\cdot$ & - & 80 \\
\hline Calamint & - & - & - & $\mathbf{1} 28$ & Crowberry & - & - & - & - I45 \\
\hline Campion & - & - & - & 32 & Crowfoot & - & - & 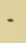 & $-\quad 10$ \\
\hline Candytuft & - & - & - & 26 & Cuckoo-pin & & - & - & - I59 \\
\hline Caraway & - & - & - & 73 & Cudweed & - & - & - & 85 \\
\hline Carline Thi & istle & - & - & 94 & Currant & - & - & - & 65 \\
\hline Carrot & - & - & - & 77 & & & & & \\
\hline Catchfly & - & - & - & 32 & Daffodil & - & - & - & I5 I \\
\hline Catmint & - & - & - & - $\quad 128$ & Daisy - & - & - & - & 84 \\
\hline Cat's Ear & - & - & - & IOI & Dame's Vio & olet & - & - & $2 \mathrm{I}$ \\
\hline Celandine, & Comn & non & - & I 5 & Dandelion & - & - & - & - IOI \\
\hline Celandine, & Lesse & & - & I I & Danewort & - & - & - & $\begin{array}{l}-79 \\
\end{array}$ \\
\hline Celery & - & - & 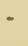 & 73 & Deadly Nig & htsh & ide & - & - $\quad$ II6 \\
\hline Centaury & - & - & - & - 109 & Dead-nettle & & - & - & $-\quad 13 I$ \\
\hline
\end{tabular}




\begin{tabular}{|c|c|c|c|c|c|c|c|c|}
\hline \multirow{3}{*}{\multicolumn{3}{|c|}{$\begin{array}{l}\text { Deptford Pink - } \\
\text { Devil's Bit Scabious }\end{array}$}} & \multirow{3}{*}{\multicolumn{2}{|c|}{$\begin{array}{r}\text { PAGE } \\
-\quad 3 I \\
-\quad 84\end{array}$}} & \multicolumn{4}{|r|}{ PAGE } \\
\hline & & & & & Fescue Grass & \multirow{3}{*}{ - } & \multirow{3}{*}{$\begin{array}{l}- \\
- \\
-\end{array}$} & \multirow{3}{*}{$\begin{array}{ll}- & \mathbf{1} 8 \mathrm{I} \\
- & \mathbf{1} \mathrm{I} 9 \\
- & \mathbf{1} 46\end{array}$} \\
\hline & & & & & Figwort & & & \\
\hline Dewberry & erry - & - & - & - 59 & Fir - - & & & \\
\hline \multicolumn{2}{|c|}{ Dock - } & - & - & - $\quad 138$ & Flag, Sweet & - & - & $-\quad$ I 59 \\
\hline \multicolumn{2}{|c|}{ Dodder } & - & - & $-\quad I I 5$ & , Yellow & - & - & I 5 I \\
\hline Dogrose & se $\quad-$ & - & - & 62 & Flax - - & - & - & -40 \\
\hline \multicolumn{2}{|c|}{ Dog's Mercury } & - & - & -140 & Fleabane & - & - & 85,88 \\
\hline \multicolumn{2}{|c|}{ Dog's-Tail Grass - } & - & - & 177 & Flixweed & - & - & $-\quad 2 \mathrm{I}$ \\
\hline \multicolumn{2}{|c|}{ Dog Violet - . } & - & - & 29 & Flowering Rush & - & - & $-\quad \mathbf{1} 6 \mathrm{I}$ \\
\hline Dogwood & ood - & $\cdot$ & - & 78 & Fluellin - & - & - & $-\quad$ II 7 \\
\hline \multicolumn{2}{|c|}{ Dropwort } & - & - & 58 & Fly Orchis - & - & - & - $\quad$ I 49 \\
\hline \multicolumn{3}{|c|}{ Dropwort, Water } & - & $\begin{array}{l}-76 \\
-160\end{array}$ & Fool's Parsley & - & - & $-\quad 76$ \\
\hline \multicolumn{2}{|c|}{ Duckweed } & - & - & - $\quad 160$ & Forget-me-not & - & - & - II2 \\
\hline \multicolumn{3}{|c|}{ Dyer's Greenweed } & - & 48 & Foxglove - & - & - & 120 \\
\hline \multicolumn{2}{|c|}{ Dỹer's Weed } & - & - & 28 & Fox-tail Grass & - & - & - $\quad 173$ \\
\hline Earthnut & nut & - & - & 74 & Frog's Bit - & - & - & $-\quad 147$ \\
\hline \multicolumn{2}{|c|}{ Eglantine } & - & - & 62 & Fumitory - & - & - & 15 \\
\hline \multirow{2}{*}{\multicolumn{2}{|c|}{$\begin{array}{l}\text { Elder - } \\
\text { Elecampane }\end{array}$}} & - & - & 79 & Furze - & - & - & $4^{8}$ \\
\hline & & - & - & 87 & & & & \\
\hline Elm & $-\quad-$ & - & - & I 4 & Garden Cress & - & - & 25 \\
\hline \multicolumn{4}{|c|}{ Enchanter's Nightshade } & $7 \mathrm{I}$ & Garlic - - & - & - & I 54 \\
\hline Eveni & ing Primros & & - & $7 \mathrm{I}$ & Garlic-mustard & - & - & 2 I \\
\hline Eyeb & right - & - & - & $-\quad \mathrm{I} 2 \mathrm{I}$ & Gean - - & - & - & 57 \\
\hline Fenne & - & - & - & 75 & Gentian - & - & - & I Io \\
\hline Fenu & greek - & - & - & 50 & Globeflower & - & - & I I \\
\hline Fern, & Beech & - & - & - 190 & Goa't's-beard & - & - & 102 \\
\hline & Bladder & - & - & $-\quad 188$ & Golden Rod & $\cdot$ & - & 84 \\
\hline & Filmy & - & - & - $\quad 185$ & Golden Samphire & & - & 87 \\
\hline & Hard - & - & - & - $\quad \mathbf{1} 86$ & Golden Saxifrage & & - & 64 \\
\hline & Hart's Tor & ggue & - & - $\quad$ I88 & Goldilocks - & . & - & Io \\
\hline & Hay-scent & & - & - $\quad 189$ & Gooseberry - & . & - & 65 \\
\hline & Holly & - & - & - $\quad$ I 88 & Goosefoot - & - & - & $-\mathbf{r} 33$ \\
\hline & Lady - & - & - & - $\quad \mathbf{1} 87$ & Goosegrass - & - & - & $8 \mathbf{I}$ \\
\hline & Male - & - & - & - $\quad \mathbf{1} 89$ & Goutweed - & - & - & 74 \\
\hline , & Marsh & - & - & 189 & Grass - - & - & - & I73 \\
\hline , & Mountain & - & - & I $\$ 9$ & Grass of Parnass & & - & 64 \\
\hline , & Oak - & - & - & 190 & Grasswrack - & - & - & - $\quad I 64$ \\
\hline & Parsley & - & - & I 86 & Gromwell - & - & - & - II 3 \\
\hline ," & Royal & - & - & - $\quad 190$ & Ground Ivy & - & - & I 29 \\
\hline ", & Scale - & - & - & - $\quad 188$ & Groundsel - & - & - & $9 \mathbf{I}$ \\
\hline , & Shield & - & - & -188 & Guelder Rose & - & - & 80 \\
\hline
\end{tabular}




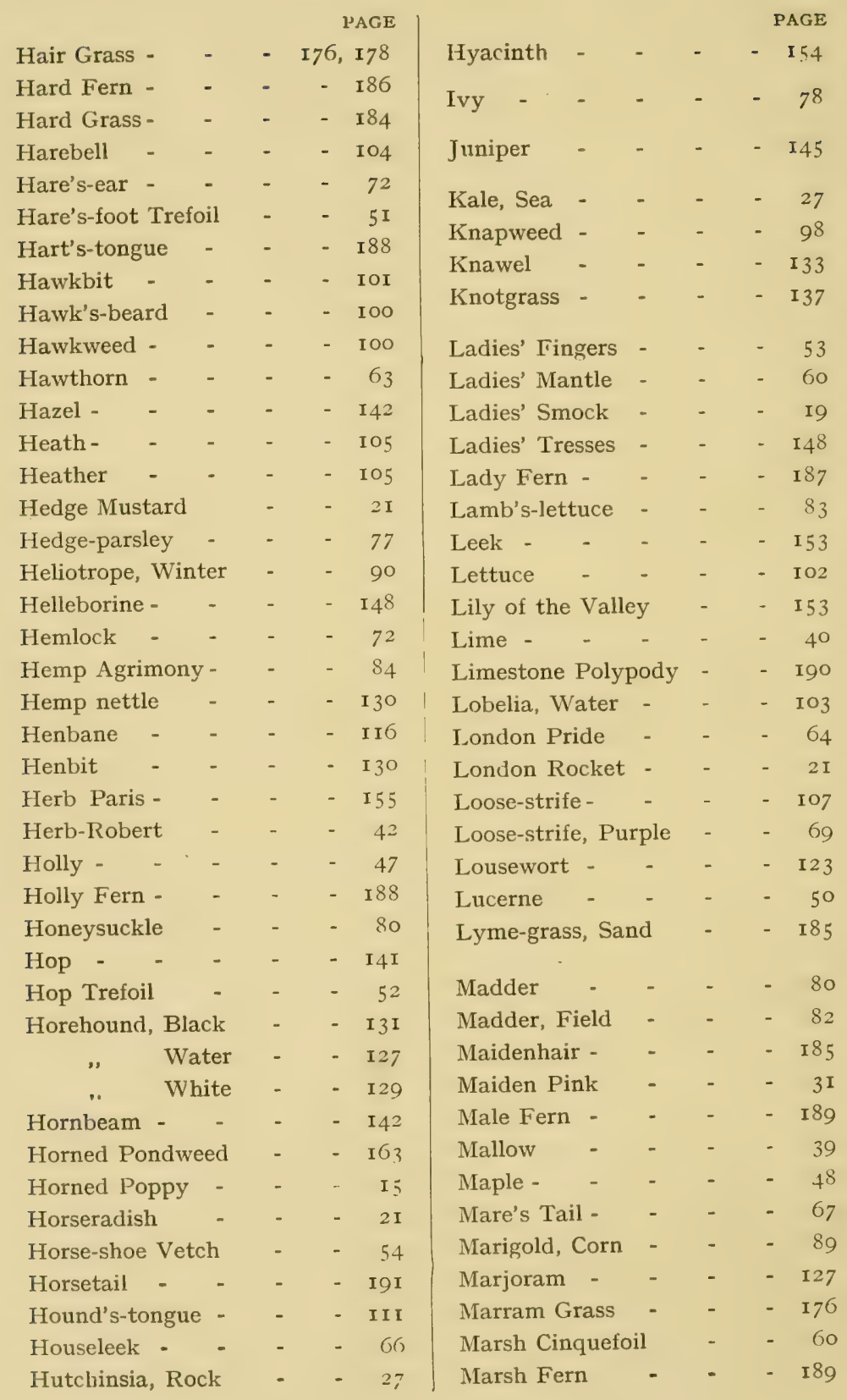




\begin{tabular}{|c|c|c|c|c|c|c|c|c|c|c|}
\hline & & & & PAGE & & & & & & $\mathrm{PAG}$ \\
\hline Marsh Mall & low & - & - & 39 & Nettle, Dea & & - & - & - & I3I \\
\hline Marsh Mari & igold & - & - & II & Nettle, Hen & $\mathrm{np}$ & - & - & - & 13 \\
\hline Mat-grass & - & - & - & $-\quad I 84$ & Nightshade & & - & - & - & I I 5 \\
\hline Mayweed & - & - & - & 88,89 & Nightshade & Enc & han & er's & - & \\
\hline Meadow Gr & rass & - & - & - $\quad 179$ & Nipplewort & & - & - & - & \\
\hline Meadow Rv & & - & - & 8 & Nitgrass & - & - & - & - & 175 \\
\hline Meadow Sa & ffron & - & - & $-\quad I 55$ & & & & & & \\
\hline Meadow Sw & veet & - & - & 58 & Oak - & - & - & - & - & \\
\hline Medick & - & - & - & 50 & Oatgrass & - & - & - & - & $x 76$ \\
\hline Melic-grass & - & - & - & $\mathbf{I} 78$ & Old Man's & Bearc & & - & - & \\
\hline Melilot & - & - & - & 50 & Orache & - & - & - & - & \\
\hline Mercury & - & - & - & 140 & Orchis & - & - & - & - & I 47 \\
\hline Mignonette & - & - & - & 28 & Orpine & - & - & - & - & \\
\hline Milfoil, Wa & ter & - & - & 67 & Osier - & - & - & - & - & I4 \\
\hline Milk Vetch & $1-$ & - & - & 54 & Oxeye - & - & - & - & - & \\
\hline Milkwort & - & - & - & $3 \mathbf{I}$ & Oxlip - & - & - & - & - & IO \\
\hline Millet Gras & & - & - & - $\quad \mathbf{I 7 4}$ & Ox-tongue & - & - & - & - & \\
\hline Mint - & - & - & - & - $\quad 125$ & & & & & & \\
\hline Mistletoe & - & - & - & $\mathbf{r} 39$ & Pæony & - & - & - & - & \\
\hline Moneywort & - & - & - & - 107 & Pansy - & - & - & - & - & 3 \\
\hline Moneywort & Corr & hish & - & - $\quad 120$ & Parsley & - & - & - & - & 73 \\
\hline Monkeyflow & ver & - & - & - II9 & Parsley Fer & & - & - & - & I 86 \\
\hline Monkshood & & - & - & $-\quad 12$ & Parsley Pie & & - & - & - & \\
\hline Moonwort & - & - & - & - I9I & Parsnip, Co & & - & - & $\cdot$ & 77 \\
\hline Moschatel & - & - & - & 79 & , W & ater & - & - & - & \\
\hline Motherwort & & - & - & - 130 & , W & ild & - & - & - & \\
\hline Mountain A & Ash & - & - & 63 & Pea, Everla & asting & - & - & - & \\
\hline Mountain $\mathrm{F}$ & Gern & - & - & - $\quad$ I89 & Pear - & - & - & - & - & 6 \\
\hline Mountain $\mathrm{E}$ & Everla & sting & - & -86 & Pearlwort & - & - & - & - & 3 \\
\hline Mudwort & - & - & - & - II9 & Pellitory & - & - & - & - & I 4 I \\
\hline Mugwort & - & - & - & 90 & Pennycress & - & - & - & - & \\
\hline Mullein & - & - & - & $-\quad$ II6 & Pennyroyal & & - & - & - & \\
\hline Muskmallov & & - & - & 39 & Pennywort & & - & - & - & 7 \\
\hline Musk Thist & & - & - & 95 & Peppermint & & - & - & - & \\
\hline Mustard & - & - & - & 23 & Pepper, Wa & ater & - & - & - & I 37 \\
\hline Mustard, T & reacle & & - & $2 \mathrm{I}$ & Pepperwort & & - & - & - & \\
\hline , W & Vall & - & - & 24 & Persicaria & - & - & - & - & I 37 \\
\hline Myrtle, Bog & & - & - & - $\quad 142$ & Pillwort & - & - & - & - & \\
\hline & & & & & Pimpernel & - & - & - & - & I08 \\
\hline Navelwort & - & - & - & 65 & Pink - & - & - & - & - & 3 \\
\hline Navew & - & - & - & 22 & Plantain & - & - & - & - & \\
\hline Nettle - & - & - & - & - I4I & Plantain, $\mathrm{V}$ & Vater & - & - & - & \\
\hline
\end{tabular}




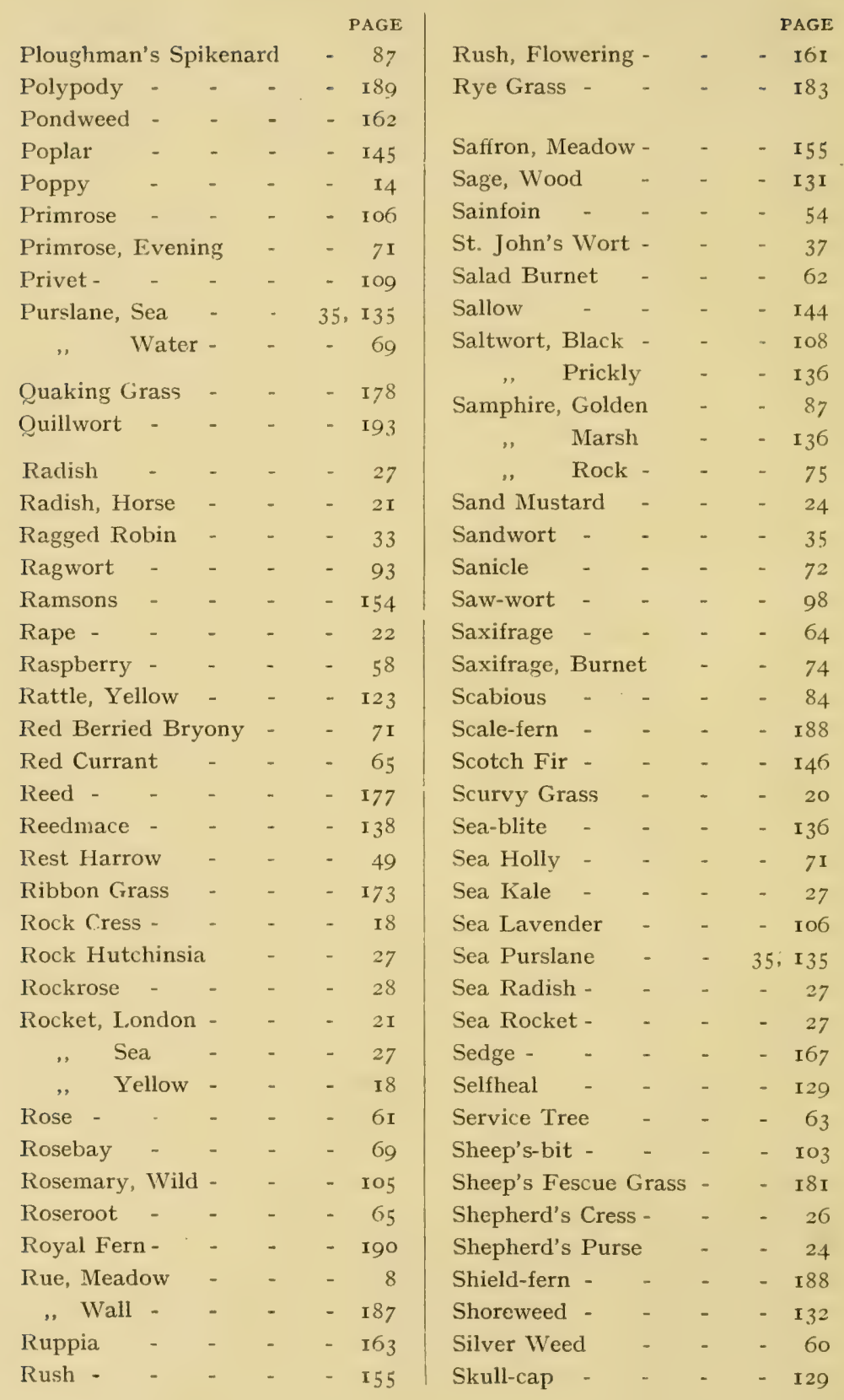


PAGE

Sloe - - - - - 57

Small-reed - - - - 175

Sneeze wort - - - 88

Snowdrop - - - - I52

Soapwort - - - - 32

Soft-grass - - - - 176

Solomon's Seal - - $\quad$ - I53

Sorrel - - - - - I39

Sorrel, Wood - - - 43

Sow Thistle - $\quad$ - $\quad$ - 102

Spearmint - - - - 126

Spearwort - - - - IO

Speedwell - - - - I20

Spikenard, Ploughman's - 87

Spindle-tree - - - 47

Spleenwort - - $\quad-\quad$ - 187

Spurge - - - $\quad$ - I39

Spurge Laurel - - $\quad$ - I39

Spurrey - - - - 36

Squill - - - - - I54

Squinancy Wort - - $\quad$ - 82

Star of Bethlehem - $\quad$ - 155

Starwort, Sea - - - 85

Water - - 68

Stitchwort - - - - 34

Stock - - - - - I7

Stonecrop - - - - 66

Stonewort - - - - 74

Stork's bill - - - - 42

Strawberry - - $\quad-\quad$ - 59

Succory - - - - 98

Sulphur-wort - - - 76

Sundew - - - - 67

Sweet-briar - - - - 62

Sweet-flag - - - - 159

Swine's Cress - - - 25

Sycamore - - - - 48

Tansy - - - - $\quad-90$

Tare - - - - $\quad$ - 54

Tea-plant - - - - r 6

Teasel -
Thistle - - - - 95

Thistle, Carline - - $\quad$ - 94

Thrift - - - - - 106

Thyme - - - - I27

Thyme, Water - - - I47

Timothy Grass - $\quad$ - $\quad$ - I74

Toad-flax - - - - II7

Toothwort - - - - I24

Tormentil - - -. - 60

Traveller's Joy - - - 8

Treacle Mustard - - $\quad$ - 2 I

Tree Mallow - $\quad$ - $\quad 39$

Trefoil - - - - 5 I

Turnip - - - - 23

Tutsan - - - - 37

Tway-blade - - - I48

Valerian - - - - 82

Vernal Grass - - $\quad$ - $\mathbf{I 7 3}$

Vervain - - - - $\mathbf{I 2 5}$

Venus' Comb - - - 75

Vetch - - - - - 55

Vetchling - - - - 56

Violet - - - - - 28

Violet, Dame's - - - $2 \mathrm{I}$

Viper's Bugloss - - - II4

Wall-cress - - - - $2 \mathrm{I}$

Wallflower - - - - I7

Wall-mustard - - $\quad$ - 24

Wall Rue - - - $\quad$ - I87

Wart-cress - - - - $\quad 24$

Water Avens - - $\quad$ - 59

Water Blinks - $\quad$ - $\quad 37$

Watercress - - - $\quad$ - 17

Water Dropwort - - - $\quad 76$

Water Horehound - - I27

Waterlily - - - - I4

Water Lobelia - - $\quad$ - 103

Water Milfoil - - - - 67

Water Mint - - $\quad$ - 26

Water Parsnip - - - 74

Water Pepper - - - I37 


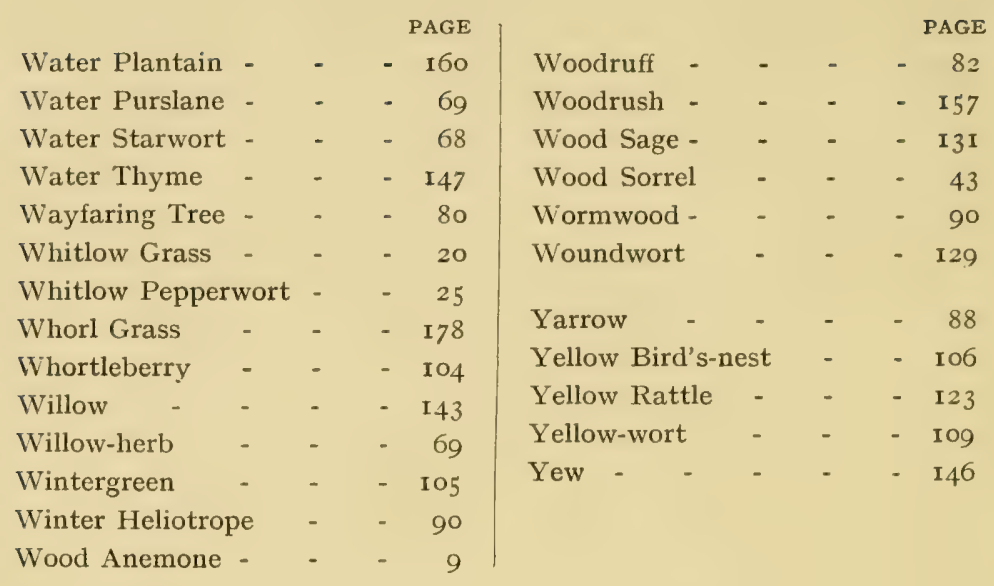




\section{ALPHABETICAL INDEX \\ OF THE ORDERS AND GENERA.}

Prepared by Mr. H. M. Hallett, Hon. Sec. of the Biological Section of the Society.

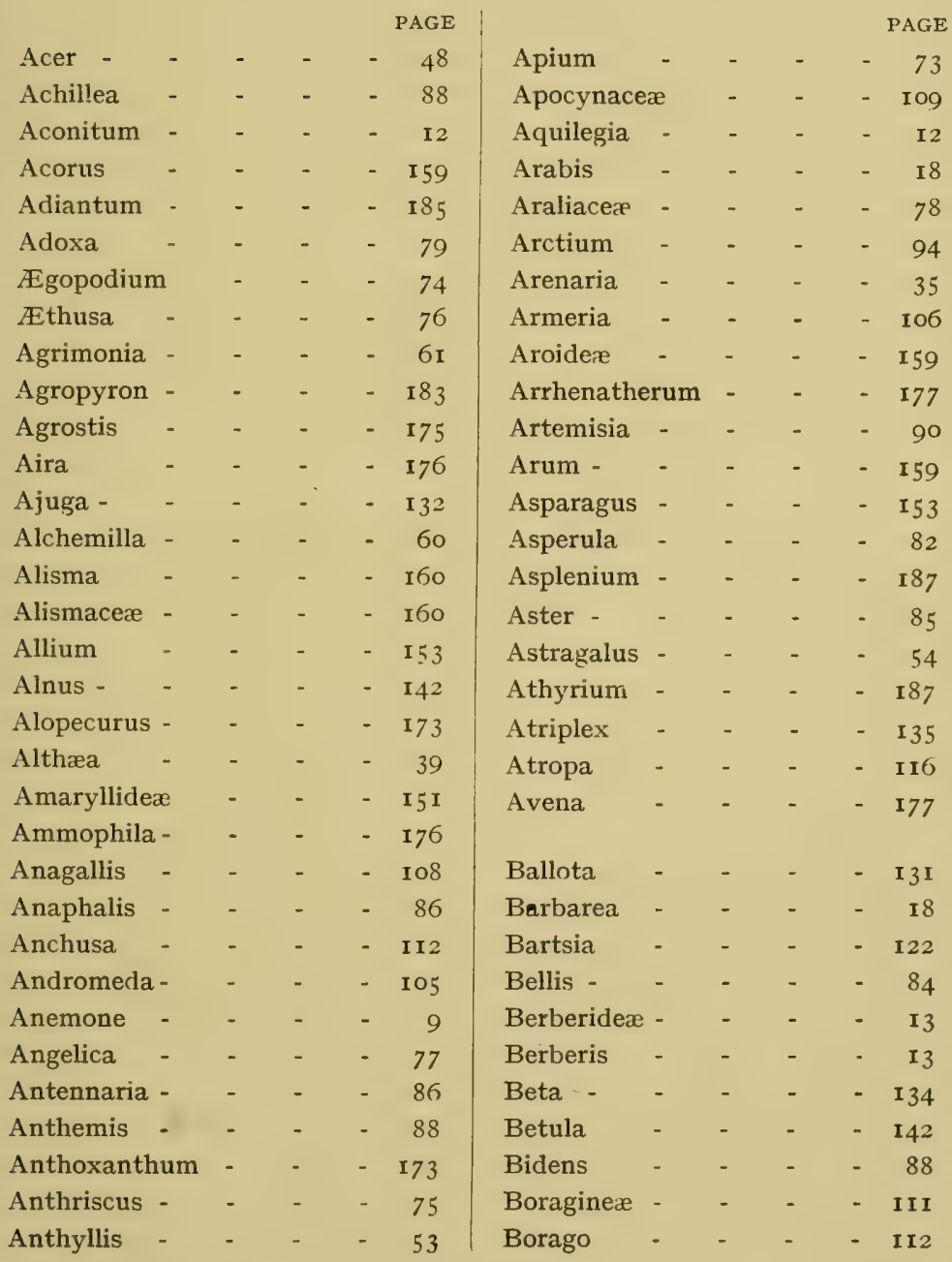




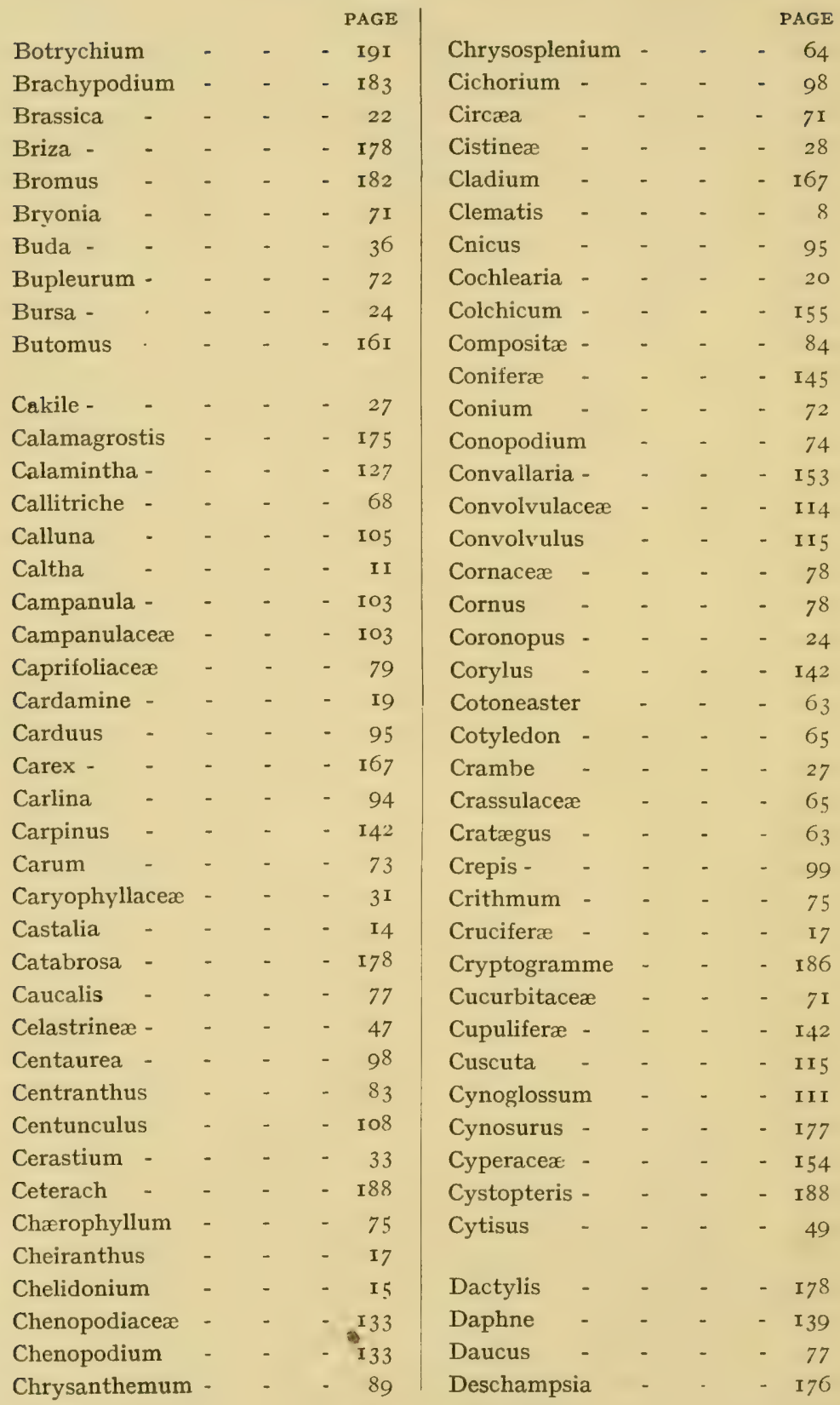




\begin{tabular}{|c|c|c|c|c|c|c|c|c|c|c|}
\hline & & & & PAGE & & & & & & PAGE \\
\hline Dianthus & - & - & - & $-\quad 3 I$ & Fraxiuus & - & - & - & - & 109 \\
\hline Digitalis & - & - & - & - 120 & Fumaria & - & - & - & - & r6 \\
\hline Dioscoreæ & - & - & - & $-\quad 152$ & Fumariaceæ & & - & - & - & $I_{5}$ \\
\hline Diplotaxis & - & - & - & 24 & & & & & & \\
\hline Dipsacexe & - & - & - & 83 & Gagea - & - & - & - & - & I 55 \\
\hline Dipsacus & - & - & - & 83 & Galanthus & - & - & - & - & 152 \\
\hline Draba - & - & - & - & I9 & Galeopsis & - & - & - & - & 130 \\
\hline Drosera & - & - & - & 67 & Galium & - & - & - & 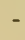 & I 80 \\
\hline Droseraceæ & - & - & - & 67 & Gastridium & - & - & - & - & I7 5 \\
\hline & & & & & Genista & - & - & - & - & 48 \\
\hline Echium & - & - & - & I I 4 & Gentiana & - & - & - & - & I IO \\
\hline Eleocharis & - & - & - & I64 & Gentianeæ & - & - & - & - & 109 \\
\hline Elisma & - & - & - & I6I & Geraniaceæ & - & - & - & - & $4 \mathrm{I}$ \\
\hline Elodea & - & - & - & I 47 & Geranium & - & - & - & & $4 I$ \\
\hline Elymus & - & - & - & 185 & Geum - & - & - & - & - & 59 \\
\hline Empetrace & & - & - & $\mathbf{I} 45$ & Glaucium & - & - & - & - & I 5 \\
\hline Empetrum & - & - & - & 145 & Glaux - & - & - & - & - & 108 \\
\hline Epilobium & - & - & - & 69 & Glyceria & - & - & - & - & $\mathbf{I} 79$ \\
\hline Epipactis & - & - & - & - $\quad 148$ & Gnaphalium & & - & - & - & 87 \\
\hline Equisetace & & - & - & I9I & Gramineæ & - & - & - & - & 173 \\
\hline Equisetum & - & - & - & - I9I & & & & & & \\
\hline Erica - & - & - & - & -105 & Habenaria & - & - & - & - & $15^{\circ}$ \\
\hline Ericaceæ & - & - & - & IO5 & Halorageæ & - & - & - & - & 67 \\
\hline Erigeron & - & - & - & 85 & Hedera & - & - & - & - & 78 \\
\hline Eriophorum & & - & - & I 66 & Helianthem & num & - & - & - & 28 \\
\hline Erodium & - & - & - & 42 & Helleborus & - & - & - & - & I 2 \\
\hline Erophila & - & - & - & 20 & Heracleum & - & - & - & - & 77 \\
\hline Eryngium & - & - & - & 71 & Herminium & $1-$ & - & - & - & 150 \\
\hline Erysimun & - & - & - & $2 \mathrm{I}$ & Hesperis & - & - & - & - & $2 I$ \\
\hline Erythræa & - & - & - & 109 & Hieracium & - & - & - & - & 100 \\
\hline Euonymus & - & - & - & 47 & Hippocrepi & & - & - & - & 54 \\
\hline Eupatorium & & - & - & 84 & Hippuris & - & - & - & - & 67 \\
\hline Euphorbia & - & - & - & - $\quad$ I 39 & Holcus & - & - & - & - & $\mathbf{I} 76$ \\
\hline Euphorbiac & cere & - & - & I 39 & Hordeum & - & - & - & - & $\mathbf{I} 84$ \\
\hline Euphrasia & - & - & - & 121 & Humulus & - & - & - & - & I 4 I \\
\hline & & & & & Hutchinsia & - & - & - & - & 27 \\
\hline Fagus - & - & - & - & - $\quad 1.43$ & Hydrochari & ideæ & - & - & - & 147 \\
\hline Festuca & - & - & - & I 80 & Hydrochari & & - & - & - & I 47 \\
\hline Filago - & - & - & - & 85 & Hydrocotyl & & - & - & - & 71 \\
\hline Filices & - & - & - & $-\quad I 85$ & Hymenoph & yllum & - & - & - & $\mathbf{1} 85$ \\
\hline Foniculum & - & - & - & - $\quad$ I66 & Hyoscyamu & & - & - & - & I 16 \\
\hline Fragaria & - & - & - & 59 & Hypericine: & & - & - & - & 37 \\
\hline
\end{tabular}




\begin{tabular}{|c|c|c|c|c|c|c|c|c|c|c|}
\hline \multirow{3}{*}{\multicolumn{2}{|c|}{$\begin{array}{l}\text { Hypericum - } \\
\text { Hypochæris }\end{array}$}} & \multicolumn{3}{|r|}{ PAGE } & \multicolumn{6}{|c|}{ PAGE } \\
\hline & & - & - & $\begin{array}{l}-\quad 37\end{array}$ & Listera & - & - & - & - & 148 \\
\hline & & - & - & - IOI & Lithosperm & um & - & - & - & II 3 \\
\hline Hypopitys & - & - & - & 106 & Littorella & - & - & - & - & 132 \\
\hline Iberis - & - & - & - & 26 & Lobelia & - & - & - & - & 103 \\
\hline Ilex - & - & - & - & 47 & Lolium & - & - & - & - & I 83 \\
\hline Ilicineæ & - & - & - & 47 & Lomaria & - & - & - & - & I 86 \\
\hline Illecebracea & & - & - & - $\quad$ I33 & Lonicera & - & - & - & - & 80 \\
\hline Impatiens & - & - & - & $43 \cdot 46$ & Loranthace & & - & - & - & $\mathbf{I} 39$ \\
\hline Inula - & - & - & - & $-\quad 87$ & Lotus - & - & - & - & - & 53 \\
\hline Irideæ & - & - & - & $-I_{5} I$ & Luzula & - & - & - & - & 1.57 \\
\hline Iris - & - & - & - & I 5 I & Lychnis & - & - & - & - & 64 \\
\hline Isoetes & - & - & - & 193 & Lycium & - & - & - & - & I 16 \\
\hline Jasione & - & - & - & & Lycopodiace & ceæ & - & - & - & I9? \\
\hline Jasione & 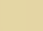 & 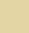 & & IO3 & Lycopodiun & & - & - & - & 192 \\
\hline Juncaceæ & - & - & - & I 55 & Lycopsis & - & - & - & - & I 12 \\
\hline Juncus & - & - & - & I 55 & Lycopus & - & - & - & - & 127 \\
\hline Juniperus & - & - & - & $\mathrm{I} 45$ & Lysimachia & - & - & - & - & 107 \\
\hline Koeleria & - & - & - & $=\quad 178$ & Lythrarieæ & - & - & - & - & \\
\hline Labiatæ & - & - & - & & Lythrum & - & - & - & - & \\
\hline Lactuca & - & - & - & $\begin{array}{r}102 \\
-\quad 102\end{array}$ & Malva - & - & - & - & - & 39 \\
\hline Lamium & - & - & - & $-\quad 130$ & Malvaceæ & - & - & - & - & 39 \\
\hline Lapsana & - & - & - & 99 & Marrubium & - & - & - & - & $\mathbf{1} 29$ \\
\hline Lastræa & - & - & - & $-\quad 189$ & Marsileaceæ & & - & - & - & I94 \\
\hline Lathræa & - & - & - & I 24 & Matricaria & - & - & - & - & 89 \\
\hline Lathyrus & - & - & - & 56 & Mathiola & - & - & - & - & I7 \\
\hline Lavatera & - & - & - & 39 & Méconopsis & - & - & - & - & I 5 \\
\hline Leguminosa & & - & - & 48 & Medicago & - & - & - & - & 50 \\
\hline Lemna & - & - & - & -160 & Melampyrur & & - & - & - & 123 \\
\hline Lemnaceæ & - & - & - & -160 & Melica & - & - & - & - & I78 \\
\hline Lentibularie & & - & - & $-\quad 124$ & Melilotus & - & - & - & - & 50 \\
\hline Leontodon & - & - & - & - IOI & Mentha & - & - & - & - & 125 \\
\hline Leonurus. & - & - & - & -130 & Menyanthes & & - & - & - & III \\
\hline Lepidium & - & - & - & 25 & Mercurialis & - & - & - & - & 140 \\
\hline Lepturus & - & - & - & $-\quad \mathbf{1} 84$ & Milium & - & - & - & - & I 74 \\
\hline Ligustrum & - & - & - & 109 & Mimulus & - & - & - & - & II9 \\
\hline Liliaceæ & - & - & - & $-\quad 152$ & Molinia & - & - & - & - & I78 \\
\hline Limosella & - & - & - & - II9 & Monotropex & & - & - & - & 106 \\
\hline Linaria & - & - & - & II 7 & Montia & - & - & - & - & 37 \\
\hline Lineæ - & - & - & - & 40 & Myosotis & - & - & - & - & I 12 \\
\hline Linum & - & - & - & 40 & Myrica & - & - & - & - & 142 \\
\hline iparis & - & - & - & - $\quad 147$. & Myricaceæ & - & - & - & - & $I_{42}$ \\
\hline
\end{tabular}




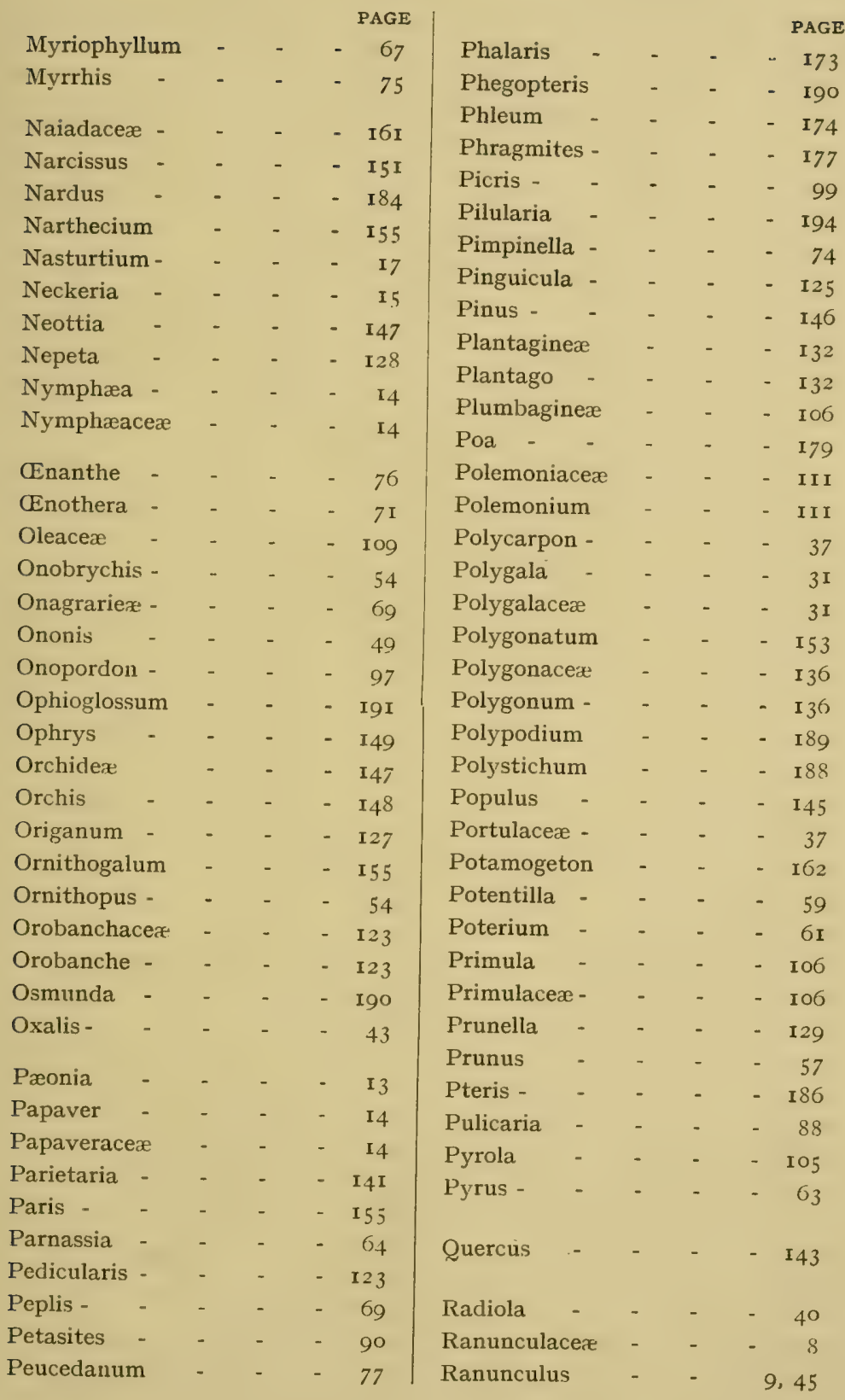




\begin{tabular}{|c|c|c|c|c|c|c|c|c|c|}
\hline \multirow{2}{*}{ Raphanus } & \multicolumn{4}{|r|}{ PAGE } & \multirow[b]{2}{*}{ Sedum } & \multirow[b]{2}{*}{ - } & \multirow[b]{2}{*}{ - } & \multicolumn{2}{|r|}{ PAGE } \\
\hline & - & - & - & $\begin{array}{l}-\quad 27 \\
-\end{array}$ & & & & - & -65 \\
\hline Reseda & - & - & - & 28 & Selaginella & - & - & - & 193 \\
\hline Resedaceæ & - & - & - & 28 & Selaginellace & eæ & - & - & I93 \\
\hline Rhamneæ & - & - & - & 47 & Sempervivu & $1 \mathrm{~m}$ & - & - & 66 \\
\hline Rhamnus & - & - & - & 47 & Senecin & - & - & - & $9 \mathrm{I}$ \\
\hline Rhinanthus & & - & - & - $\quad 123$ & Serratula & - & - & - & 98 \\
\hline Ribes - & - & - & - & -65 & Sherardia & - & - & - & 82 \\
\hline Rosa - & - & - & - & $6 \mathbf{I}$ & Sibthorpia & - & - & - & I 20 \\
\hline Rosaceæ & - & - & - & 57 & Sioglingia & - & - & - & I 77 \\
\hline Rubia - & - & - & - & 80 & Silaus - & - & $\cdot$ & - & -76 \\
\hline Rubiace & - & - & - & 80 & Silene - & - & - & - & $32,4^{6}$ \\
\hline Rubus & - & - & - & $5^{8}$ & Sison - & - & - & - & 74 \\
\hline Rumex & - & - & - & $-\quad 138$ & Sisymbrium & & - & - & 21 \\
\hline Ruppia & - & - & - & $\mathbf{I} 63$ & Sium - & - & - & - & 74 \\
\hline Ruscus & - & - & - & I 52 & Smyrnium & - & - & - & $\begin{array}{l}-\quad 72 \\
\end{array}$ \\
\hline \multirow{2}{*}{\multicolumn{2}{|c|}{ Rynchospora }} & - & - & 166 & Solanaceæ & - & - & - & $-\quad$ II5 \\
\hline & & & & & Solanum & - & - & - & - II5 \\
\hline Sagina & - & - & - & 35 & Solidago & - & - & - & 8.4 \\
\hline Sagittaria & - & - & - & $-\quad \mathbf{r} 6 \mathbf{I}$ & Sonchus & - & - & - & $-\quad 102$ \\
\hline Salicinex & - & - & - & I 43 & Sparganium & & - & - & $-\quad$ I 58 \\
\hline Salicornia & - & - & - & I 36 & Spergula & - & - & - & 36 \\
\hline Salix - & - & - & - & I 43 & Spergularia & - & - & - & 37 \\
\hline Salsola & - & - & - & I 36 & Spiræa & - & - & - & 58 \\
\hline Salvia - & - & - & - & I 28 & Spiranthes & - & - & - & 148 \\
\hline Sambucus & - & - & $\cdot$ & 79 & Stachys & - & - & - & 129 \\
\hline Samolus & - & - & - & I08 & Statice & - & - & - & 106 \\
\hline Sanicula & - & - & - & 72 & Stellaria & - & - & - & 34 \\
\hline Sapindacex & - & - & - & 48 & Suæda & - & - & - & I 36 \\
\hline Saponaria & - & - & - & 32 & Symphytum & & - & - & I I I \\
\hline Saxifraga & - & - & - & 64 & & & & & \\
\hline Saxifragace & & - & - & 64 & Tamus & - & - & - & I 52 \\
\hline Scabiosa & - & - & - & 84 & Tanacetum & - & $\cdot$ & - & 90 \\
\hline Scandix & - & - & - & 75 & Taraxacum & - & - & - & IOI \\
\hline Schœnus & - & - & - & $-\quad$ I67 & Taxus - & - & - & - & I 46 \\
\hline Schollera & - & - & - & - $\quad 104$ & Teucrium & - & - & - & I $3 I$ \\
\hline Scilla - & - & - & - & $-\quad I 54$ & Thalictrum & - & - & - & - \\
\hline Scirpus & - & - & - & $-\quad I 64$ & Thlaspi & - & - & - & 26 \\
\hline Scleranthus & & - & - & $-\quad 133$ & Thymelæace & еæ & - & - & I 39 \\
\hline Scolopendri & ium & - & - & $-\quad 188$ & Thymus & - & - & - & I 27 \\
\hline Scrophular & & - & - & - $\quad$ II7 & Tilia - & - & $\cdot$ & - & 40 \\
\hline Scrophulari & ineæ & - & - & - $\quad$ Ir6 & Tiliaceæ & - & - & - & - 40 \\
\hline Scutellaria & - & - & - & - $\quad 129$ & Tragopogon & & - & - & - 102 \\
\hline
\end{tabular}




\begin{tabular}{|c|c|c|c|c|c|c|c|c|c|}
\hline & & & & PAGE & \multirow{2}{*}{\multicolumn{2}{|c|}{ Valerianella }} & & & PAGE \\
\hline Trifolium & - & - & - & $-\quad 5 I$ & & & - & - & -83 \\
\hline Triglochin & - & - & - & - $\quad$ I6I & \multicolumn{2}{|c|}{ Verbascum - } & - & - & I I 6 \\
\hline Trigonella & - & - & - & 50 & Verbena & - & - & - & I 25 \\
\hline Trisetum & - & - & - & I76 & \multicolumn{2}{|c|}{ Verbenaceæ } & - & - & I25 \\
\hline Trollius & - & - & - & II & Veronica & - & - & - & 120 \\
\hline Tussilago & - & - & - & 90 & Viburnum & - & - & - & 80 \\
\hline Typha & - & - & - & I 58 & Vicia - & - & - & - & 54 \\
\hline Typhaceæ & - & - & - & $\mathbf{I}_{5} 8$ & Vinca - & - & - & - & - 109 \\
\hline & & & & & Viola - & - & - & - & 28,45 \\
\hline Ulex - & - & - & - & 48 & Violarieæ & - & - & - & $\begin{array}{l}-\quad 28 \\
\end{array}$ \\
\hline Ulmus & - & - & - & I $4 \mathrm{I}$ & Viscum & - & - & - & I 39 \\
\hline Umbellifer & & - & - & $7 \mathrm{I}$ & Volvulus & - & - & - & $\mathrm{II}_{4}$ \\
\hline Urtica & - & - & - & - I4I & & & & & \\
\hline Urticaceæ & - & - & - & $\mathrm{I}_{4} \mathrm{I}$ & \multicolumn{2}{|c|}{ Wahlenbergia } & - & - & IO3 \\
\hline Utricularia & - & - & - & 124 & \multicolumn{2}{|c|}{ Weingærtneria } & - & - & I 76 \\
\hline Vacciniacex & & - & - & IO4 & Wolffia & - & - & - & - $\quad \mathbf{1 6 0}$ \\
\hline Vaccinium & - & - & - & 104 & \multicolumn{2}{|l|}{ Zannichellia } & - & & - $\quad$ I63 \\
\hline Valeriana & - & - & - & 82 & Zostera & - & - & - & I64 \\
\hline Valerianeæ & - & - & - & 82 & & & & 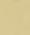 & \\
\hline
\end{tabular}



